UNIVERSIDADE DE SÃO PAULO

FACULDADE DE ECONOMIA, ADMINISTRAÇÃO E CONTABILIDADE DEPARTAMENTO DE ADMINISTRAÇÃO

PROGRAMA DE PÓS-GRADUAÇÃO EM ADMINISTRAÇÃO

\title{
INTERNACIONALIZAÇÃO DO VAREJO: UM ESTUDO COM EMPRESAS BRASILEIRAS POR MEIO DE ANÁLISE DE CONTEÚDO
}

Adriana Beatriz Madeira

Orientador: Prof. Dr. José Augusto Giesbrecht da Silveira

SÃO PAULO

2009 
Profa. Dra. Suely Vilela

Reitora da Universidade de São Paulo

Prof. Dr. Carlos Roberto Azzoni

Diretor da Faculdade de Economia, Administração e Contabilidade

Prof. Dr. Isak Kruglianskas

Chefe do Departamento de Administração

Prof. Dr. Lindolfo Galvão de Albuquerque

Coordenador do Programa de Pós-Graduação em Administração 


\title{
INTERNACIONALIZAÇÃO DO VAREJO: UM ESTUDO COM EMPRESAS BRASILEIRAS POR MEIO DE ANÁLISE DE CONTEÚDO
}

\author{
Tese apresentada ao Departamento de \\ Administração da Faculdade de Economia, \\ Administração e Contabilidade da \\ Universidade de São Paulo como requisito \\ para a obtenção do título de Doutor em \\ Administração.
}

Orientador: Prof. Dr. José Augusto Giesbrecht da Silveira

SÃO PAULO

2009 
FICHA CATALOGRÁFICA

Elaborada pela Seção de Processamento Técnico do SBD/FEA/USP

Madeira, Adriana Beatriz

Internacionalização de varejo: um estudo com empresas brasileiras por meio de análise de conteúdo / Adriana Beatriz Madeira. - São Paulo, 2009.

$233 \mathrm{p}$.

Tese (Doutorado) - Universidade de São Paulo, 2009

Bibliografia.

1. Internacionalização de empresas 2. Varejo 3. Análise de conteúdo I. Universidade de São Paulo. Faculdade de Economia, Administração e Contabilidade II. Título.

CDD - 658.049 
À minha mãe. 
Agradeço ao professor doutor e orientador José Augusto Giesbrecht da Silveira, por incentivar a inovação, qualidade e perfeição, e por me acolher e apoiar em mais esta etapa de minha formação como docente.

Agradeço ao professor doutor Cláudio Felisoni de Ângelo, da FEA-USP e PROVAR, por seu suporte e incentivo.

Agradeço a minha mãe, Marlene Madeira, pela sua vibração e felicidade em mais uma etapa de minha formação como docente e por ser a amiga de todas as horas.

Agradeço à equipe do IME-USP pela ativa participação na definição da metodologia de pesquisa, especialmente aos professores Gilberto Alvarenga Paula e Lúcia Pereira Barrosa, e a Sylvia Regina Aguiar Cavalcante Takahashi, do CEA-IME, pela ajuda incondicional para a viabilização deste estudo.

Agradeço à professora Viviana Giampaoli, do IME-USP, pelas contribuições ao longo de toda a confecção desta tese.

Agradeço ao professor Marcos Lopes, da FFLCH-USP, pela efetiva participação na confecção da metodologia para análise de conteúdo dos dados da tese e sua contribuição como lingüista. Agradeço à professora Maria José Baraldi pela efetiva participação como lingüista na análise de conteúdo dos dados da tese.

Agradeço a Fabiana Pansonato e Renata Brunelli pelas contribuições ao longo da análise dos dados da tese.

Agradeço a Alice Sobral Singer e Leonardo Sonoda pelas informações relevantes para a confecção deste trabalho.

Agradeço à professora Patrícia Vance, do PROVAR, pela ajuda efetiva e incansável para promover os contatos com os profissionais e as empresas que compõem a parte empírica do estudo. A sua participação fez toda a diferença.

Agradeço a João Baptista da Silva Junior pela ajuda efetiva na promoção dos contatos com os profissionais e as empresas que compõem a parte empírica do estudo. Por meio de sua indicação, consegui as entrevistas de O Boticário, Mundo Verde, Livraria Nobel, Spoleto e Marisol (Lilica Ripilica e Rosa Chá)

Agradeço a Luis Henrique Stockler por dispor de seu tempo e sua atenção, pela entrevista da Victor Hugo e pela indicação das empresas Chilli Beans e Morana.

Agradeço a Derek George Moor Wagner por dispor de seu tempo e sua atenção.

Agradeço a Jae Ho Lee por abrir sua empresa, a Morana, para fazer parte do estudo.

Agradeço a Mario Ponci Neto por dispor de seu tempo e sua atenção, e pela entrevista da Chilli Beans. 
Agradeço a Patrícia Birman por abrir sua empresa, a Arezzo, para fazer parte do estudo. Agradeço a Mario Goldberg por dispor de seu tempo e sua atenção, e pela entrevista da Arezzo.

Agradeço ao Sr. Jorge Eduardo Antunes por dispor de seu tempo e sua atenção, e por abrir sua empresa, Mundo Verde, para fazer parte do estudo.

Agradeço ao Sr. Roberto Garcia Neves por dispor de seu tempo e sua atenção e pela entrevista de $O$ Boticário. Agradeço especialmente a Vera Lúcia Lombello de Magalhães por colocar todo o seu empenho na viabilização da entrevista.

Agradeço ao Sr. Robson Amorim por dispor de seu tempo e sua atenção, e pela entrevista da Marisol.

Agradeço ao Sr. Antonio Bento Moreira Leite por dispor de seu tempo e sua atenção, e pela entrevista do Spoleto.

Agradeço ao Sr. Sérgio Milano por dispor de seu tempo e sua atenção, e pela entrevista da Livraria Nobel.

Agradeço a Melissa Franchini Cavalcanti Bandos pela ajuda efetiva e incansável para promover o contato com a empresa Carmen Steffens.

Agradeço ao Sr. Gabriel Spaniol por dispor de seu tempo e sua atenção, e pela entrevista da Carmen Steffens.

Agradeço a toda a equipe do PPGA, da Secretaria de Pós-Graduação, Biblioteca e UPD da FEA-USP pela ativa colaboração.

Agradeço ao professor Claudio Alberto de Moraes, da Universidade Presbiteriana Mackenzie, pela compreensão e apoio ao longo de todo o processo.

Agradeço ao amigo e professor Guilherme de Farias Shiraishi, da Universidade Presbiteriana Mackenzie, pelo incentivo e apoio em todos os momentos.

Agradeço ao professor Gilberto Perez, da Universidade Presbiteriana Mackenzie, pela efetiva participação na confeç̧ão da metodologia de pesquisa empregada na tese.

Agradeço à professora Maria C. Lage, da Universidade Presbiteriana Mackenzie, pela efetiva contribuição na análise de dados qualitativos da tese.

Agradeço à professora Márcia Serra Ribeiro Vianna, da Universidade Presbiteriana Mackenzie, pela atenção em todas as horas.

Agradeço ao professor Francisco Américo Cassano, da Universidade Presbiteriana Mackenzie, pela ajuda e por me apresentar bibliografia fundamental para a compreensão do tema da internacionalização. 
Agradeço aos professores Luciano Augusto de Toledo e Aurio Lucio Leocadio da Silva, da Universidade Presbiteriana Mackenzie, que me ajudaram a viabilizar esta conquista. Agradeço à querida amiga e professora Heidy R. Ramos pela ajuda incondicional e pelo incentivo ao longo de todo o caminho até a conclusão da tese.

Agradeço à amiga e professora Karen Perrota, da Universidade Presbiteriana Mackenzie, pelo incentivo ao longo da tese.

Agradeço a meus queridos amigos Cíntia, Fábio, André, Claudia, Ítalo e Gilnei, que me apoiaram ao longo de todo o caminho.

Agradeço aos professores Eduardo Terra, Nuno Maria Fouto e Marcos Roberto Luppe, do PROVAR, pelo apoio e compreensão.

Agradeço a toda a equipe do PROVAR, que colaborou e vibrou a cada etapa deste trabalho.

Agradeço ao professor doutor Luiz Paulo Fávero, da FEA-USP, pelo incentivo em todas as ocasiões.

Agradeço ao professor Marcos Roberto Piscopo pela atenção especial e por localizar e encaminhar bibliografia rara e imprescindível à tese. 


\section{RESUMO}

A década de 70 foi caracterizada por grande atividade de construtoras brasileiras no exterior, particularmente na África e no Oriente Médio. Nos anos 80, as organizações brasileiras destacaram-se pelo grande fluxo de investimentos realizados no exterior, e na década de 90 , em conseqüência da abertura comercial que houve em nosso país, as empresas brasileiras foram buscar atualização tecnológica no exterior, para enfrentar competidores estrangeiros. Esse movimento de internacionalização caracterizou-se principalmente pelo deslocamento de empresas do setor industrial; a internacionalização das empresas de varejo é um fenômeno mais recente. Pesquisas sobre o processo de internacionalização da empresa varejista brasileira ainda não são muito numerosas no país, o que talvez se deva ao fato de que esse fenômeno ainda é relativamente recente no cenário brasileiro. Nesse contexto o estudo objetivou investigar a relação entre as teorias sobre internacionalização de empresas e o processo de expansão de empresas de varejo brasileiras para países estrangeiros e identificar o que leva uma empresa a se deslocar para outros países, para onde se desloca (por que escolhe determinados locais em detrimento de outros), quais são os modos de entrada selecionados e como as empresas se adaptam aos novos locais, sob os conceitos de internacionalização de empresas. O estudo utilizou dados secundários provenientes de teses, dissertações, artigos e Internet, além de dados primários coletados em entrevistas em profundidade com os principais gestores de dez empresas de varejo brasileiras. A metodologia de pesquisa empregada englobou a Análise de Conteúdo e a Análise de Correspondência. Um dos resultados do trabalho foi a proposta de uma Taxonomia de Encadeamento Teórico sobre a internacionalização de empresas. A análise dos dados mostrou que todas as estruturas teóricas registradas nesta tese foram identificadas no processo de internacionalização das empresas de varejo brasileiras pesquisadas. 


\begin{abstract}
The decade of 1970 was characterized by the intense activity of Brazilian construction companies abroad, particularly in Africa and the Middle East. In the eighties, Brazilian organizations stood out because of the large flow of investments they made abroad and in the nineties, as a result of the trade opening made in our country, Brazilian companies sought updated technology abroad to face foreign competitors. However, the movement of internationalization is primarily characterized by the displacement of industrial companies. The internationalization of retail businesses is a more recent phenomenon. Studies on the process of internationalization of Brazilian retail companies are not numerous yet in the country. This may be due to the fact that this is a still relatively recent phenomenon in the Brazilian scene. Therefore, this study aimed to investigate the relationship between the internationalization theories and the expansion process of Brazilian retail companies towards other countries. Additionally, by using the concepts of international business, this work sought to identify why companies go global, where they head, which entry modes they employ and how they adapt themselves to new locations. This work has utilized secondary data retrieved from theses, dissertations, articles and internet, besides primary data collected through in-depth interviews with executives from 10 Brazilian retail companies. Content Analysis and Correspondence Analysis techniques were employed. Findings a taxonomy for theoretical comprehension of the phenomenon under investigation. Data analysis showed that all theoretical frameworks employed in this work were present in the internationalization process of Brazilian retail companies.
\end{abstract}




\section{SUMÁRIO}

LISTA DE QUADROS

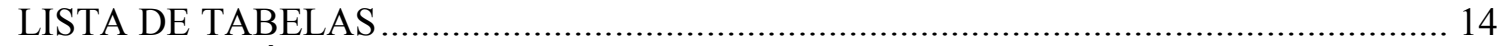

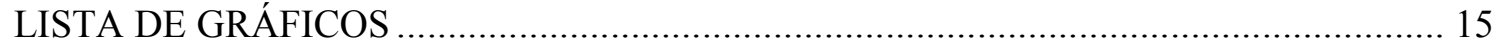

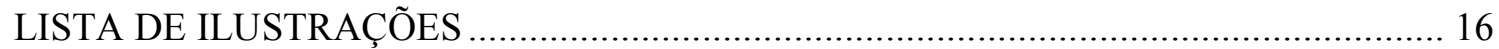

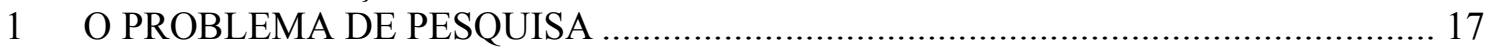

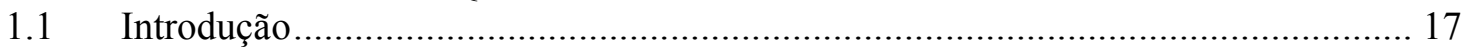

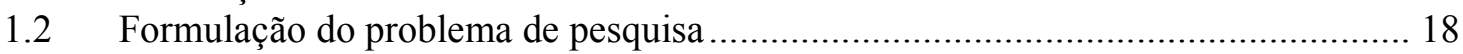

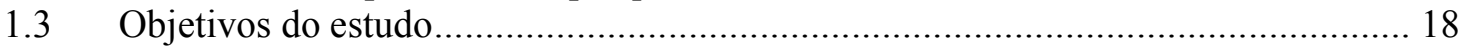

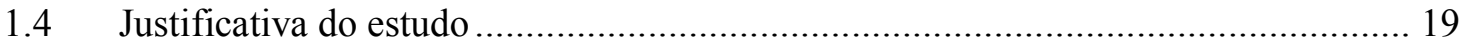

1.4.1 Globalização e internacionalização ............................................................ 19

1.4.2 Motivos, estratégias e riscos da internacionalização ........................................ 22

1.4.3 Internacionalização de empresas brasileiras ................................................... 26

1.4.4 Fatores que interferem na internacionalização de empresas brasileiras ............... 28

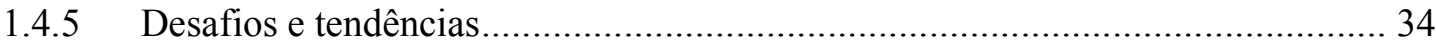

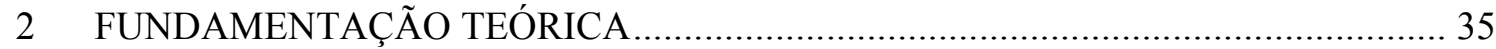

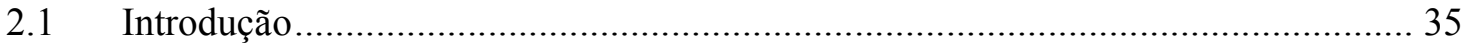

2.2 Conceituação das teorias de internacionalização com base no enfoque

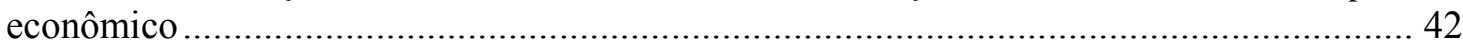

2.2.1 Teoria do Poder de Mercado .............................................................................. 42

2.2.1.1 Teoria da Firma - Teoria dos Custos de Transação........................................ 46

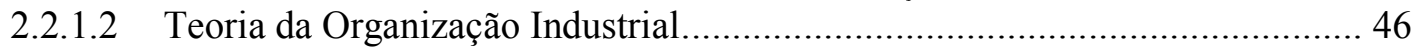

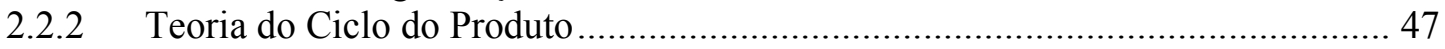

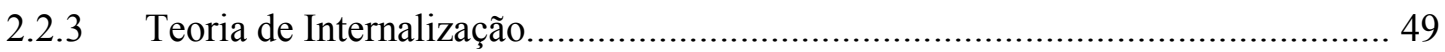

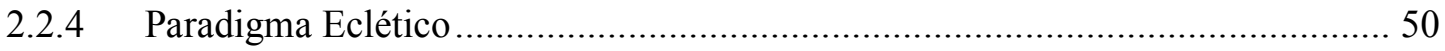

2.3 Conceituação das teorias de internacionalização com base no enfoque

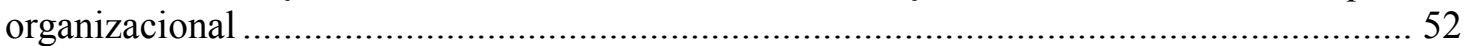

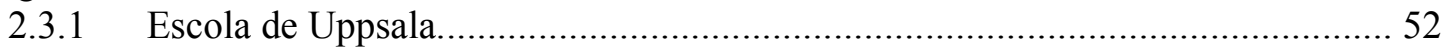

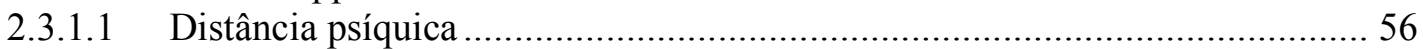

2.3.1.2 Industrial networks ou redes de relacionamento .................................... 57

2.3.2 Escola Nórdica de Negócios Internacionais..................................................... 59

2.4 Conceituação das teorias de internacionalização com base no enfoque gerencial ...... 60

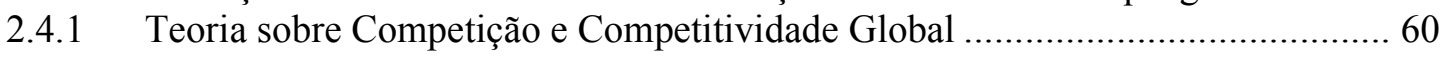

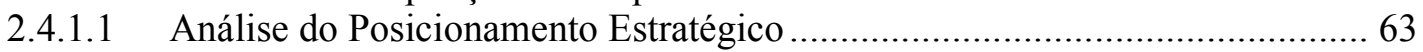

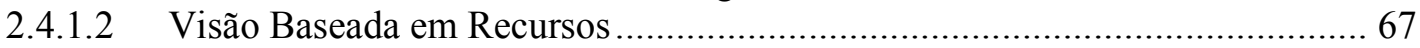

2.4.2 Abordagem sobre Gestão Estratégica de Operações ........................................ 68

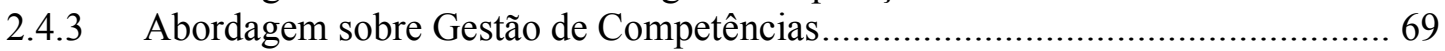

2.4.4 Abordagem sobre Gestão do Conhecimento .................................................... 71

2.5 Conceituação da teoria de internacionalização com base no enfoque cultural............ 72

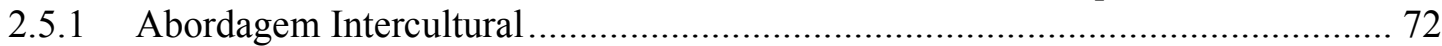

2.6 Conclusão das teorias e abordagens sobre internacionalização.............................. 75

2.7 Teorias e abordagens sobre internacionalização do varejo ................................... 78

2.7.1 Fatores que interferem na internacionalização do varejo ................................. 79

2.7.2 Estratégias de internacionalização do varejo ................................................. 83

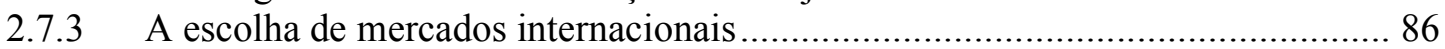

2.8 Conclusão da fundamentação teórica.......................................................... 92

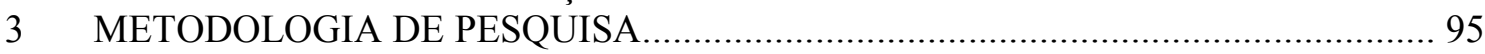

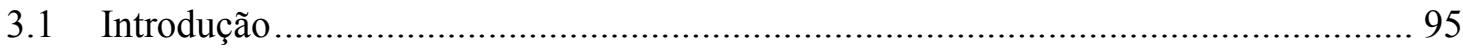


3.2 Fundamentos teóricos da Análise de Conteúdo ..................................................... 95

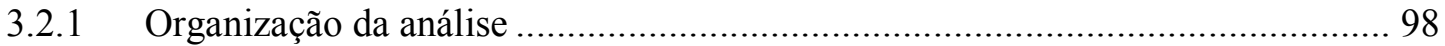

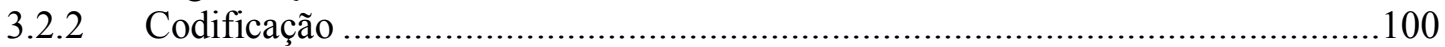

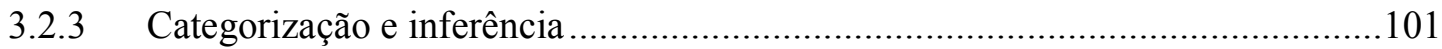

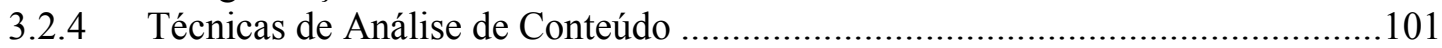

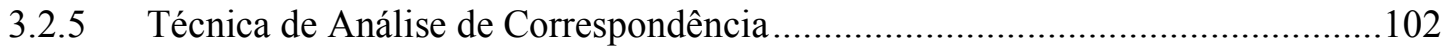

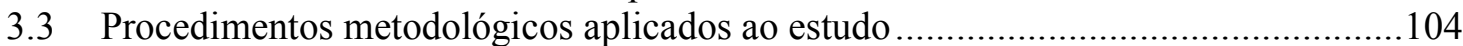

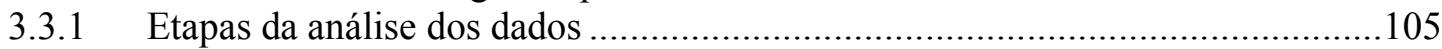

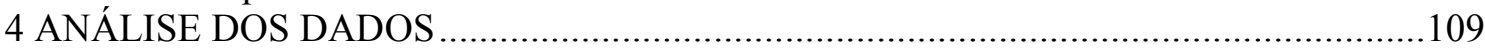

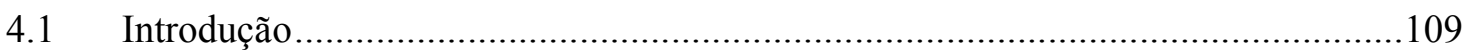

4.2 Caracterização das empresas pesquisadas...................................................... 109

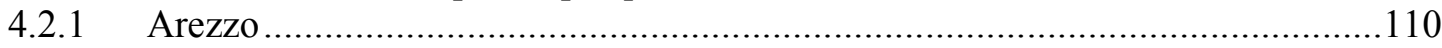

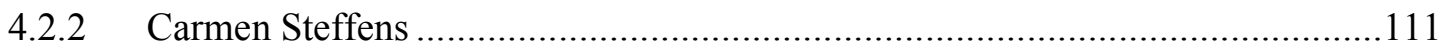

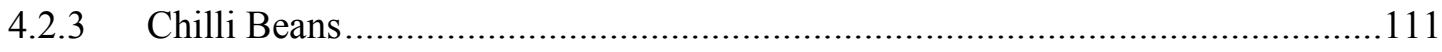

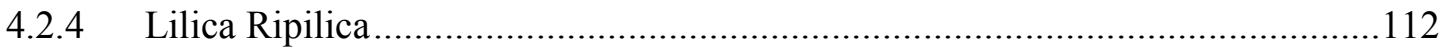

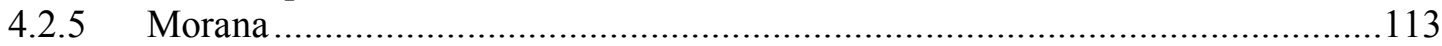

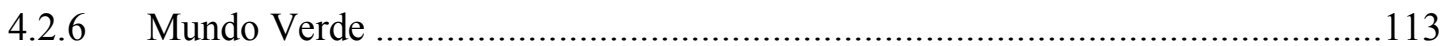

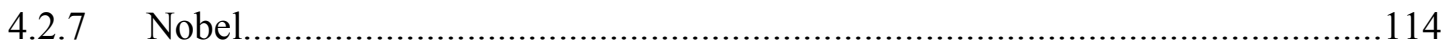

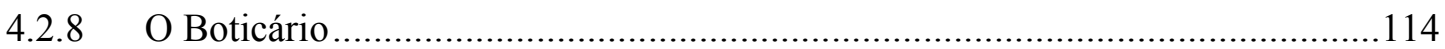

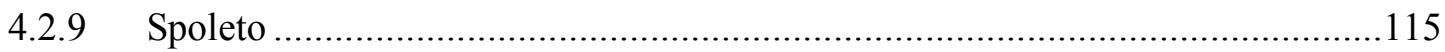

4.2.10 Victor Hugo ..................................................................................... 116

4.3 O processo de internacionalização das empresas de varejo brasileiras: proposições

4.3.1 Análise dos dados por proposição e por empresa para a totalidade do processo

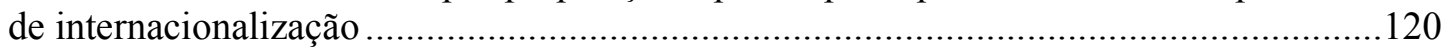

4.3.2 Análise dos dados por proposição e por empresa: por que sair ........................128

4.3.3 Análise dos dados por proposição e por empresa: para onde ir .........................132

4.3.4 Análise dos dados por proposição e por empresa: como entrar no novo local ....136

4.3.5 Análise dos dados por proposição e por empresa: como se adaptar ao novo

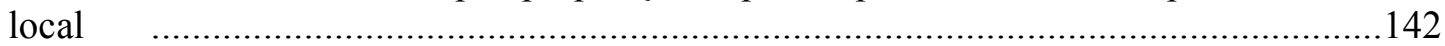

4.4 O processo de internacionalização das empresas de varejo brasileiras: teorias .......147

4.4.1 Análise dos dados por teoria e por empresa: por que sair ...............................151

4.4.2 Análise dos dados por teoria e por empresa: para onde ir ...............................152

4.4.3 Análise dos dados por teoria e por empresa: como entrar no novo local ............154

4.4.4 Análise dos dados por teoria e por empresa: como se adaptar ao novo local......156

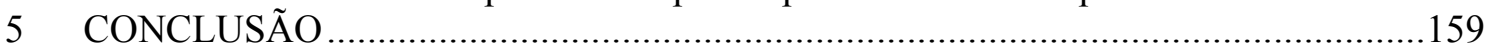

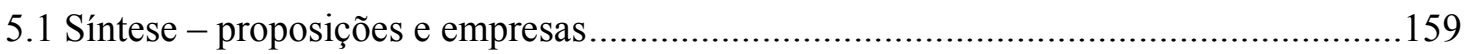

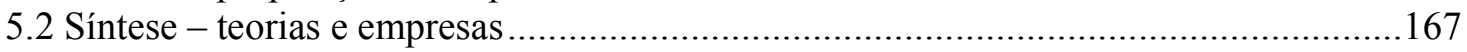

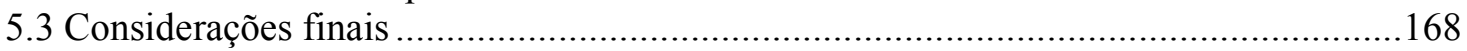

5.4 Limitações do estudo e sugestão para pesquisas futuras .........................................172

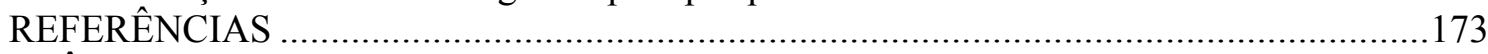

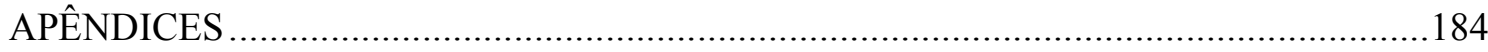




\section{LISTA DE QUADROS}

Quadro 1 - Domínios possíveis da aplicação da análise de conteúdo................................. 98

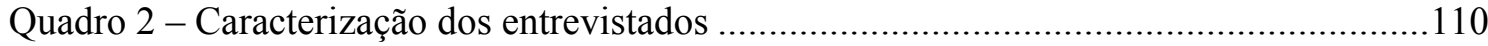

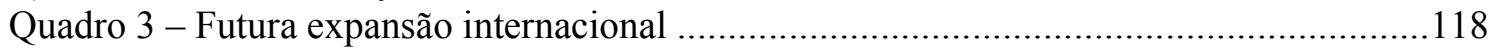

Quadro 4 - Teorias relacionadas a por que sair para cada empresa ...................................151

Quadro 5 - Teorias relacionadas a para onde ir para cada empresa....................................153

Quadro 6 - Teorias relacionadas a como entrar para cada empresa: $1^{\mathrm{a}}$ parte .......................154

Quadro 7 - Teorias relacionadas a como entrar para cada empresa: $2^{\mathrm{a}}$ parte .......................155

Quadro 8 - Teorias relacionadas a como se adaptar para cada empresa: $1^{\mathrm{a}}$ parte ................156

Quadro 9 - Teorias relacionadas a como se adaptar para cada empresa: $2^{\mathrm{a}}$ parte .................157 


\section{LISTA DE TABELAS}

Tabela 1 - Freqüência das proposições por entrevista: $1^{\mathrm{a}}$ parte 121

Tabela 2 - Freqüência das proposições por entrevista: $2^{\mathrm{a}}$ parte

Tabela 3 - Freqüência das proposições por entrevista: $3^{\text {a }}$ parte

Tabela 4 - Freqüência das proposições por entrevista: $4^{\mathrm{a}}$ parte

Tabela 5 - Freqüência das proposições por entrevista: por que sair $-1^{\text {a }}$ parte

Tabela 6 - Freqüência das proposições por entrevista: por que sair $-2^{\mathrm{a}}$ parte

Tabela 7 - Freqüência das proposições por entrevista: para onde ir $-1^{\mathrm{a}}$ parte

Tabela 8 - Freqüência das proposições por entrevista: para onde ir $-2^{\mathrm{a}}$ parte

Tabela 9 - Freqüência das proposições por entrevista: como entrar no novo local $-1^{\mathrm{a}}$

parte

Tabela 10 - Freqüência das proposições por entrevista: como entrar no novo local $-2^{\mathrm{a}}$

parte

Tabela 11 - Freqüência das proposições por entrevista: como entrar no novo local $-3^{\mathrm{a}}$

parte

Tabela 12 - Freqüência das proposições por entrevista: como entrar no novo local $-4^{\mathrm{a}}$ parte

Tabela 13 - Freqüência das proposições por entrevista: como se adaptar ao novolocal $-1^{\text {a }}$ parte

Tabela 14 - Freqüência das proposições por entrevista: como se adaptar ao novo local $2^{\mathrm{a}}$ parte

Tabela 15 - Freqüência das proposições por entrevista: como se adaptar ao novo local $3^{\mathrm{a}}$ parte

Tabela 16 - Processo de Internacionalização 


\section{LISTA DE GRÁFICOS}

Gráfico 1 - Análise de Correspondência por proposição e por empresa .............................127

Gráfico 2 - Imagem ampliada da região de maior concentração de pontos do Gráfico 1 ......128

Gráfico 3 - Análise de Correspondência por proposição e por empresa: por que sair ...........131

Gráfico 4 - Análise de Correspondência por proposição e por empresa: para onde ir...........135

Gráfico 5 - Análise de Correspondência por proposição e por empresa: como entrar no novo local.

Gráfico 6 - Análise de Correspondência por proposição e por empresa: como se adaptar

ao novo local ....

Gráfico 7 - Análise de Correspondência por proposição e por empresa: dados

agregados.

Gráfico 8 - Análise de Correspondência: por que sair

Gráfico 9 - Análise de Correspondência: para onde ir.

Gráfico 10 - Análise de Correspondência: como entrar no novo local.

Gráfico 11 - Análise de Correspondência: como se adaptar ao novo local ...........................157

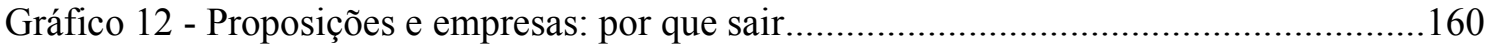

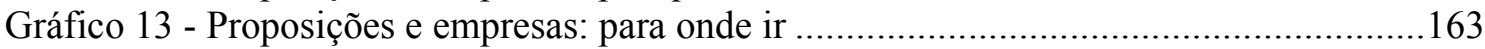

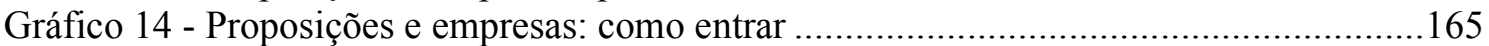

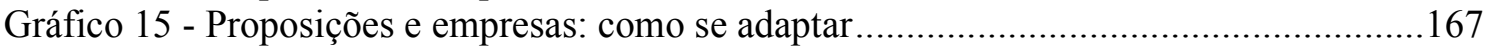

Gráfico 16 - Processo de Internacionalização .................................................................170 


\section{LISTA DE ILUSTRAÇÕES}

Ilustração 1 - A conexão entre fatores ambientais e fatores motivacionais na

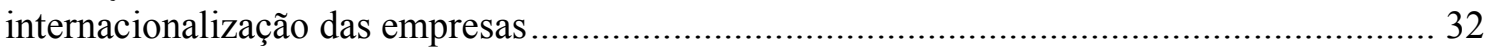

Ilustração 2 - Internacionalização da firma - enfoque econômico...................................... 38

Ilustração 3 - Internacionalização da firma - enfoque organizacional ................................... 38

Ilustração 4 - Internacionalização da firma - enfoque gerencial......................................... 40

Ilustração 5 - Internacionalização da firma - enfoque cultural .......................................... 40

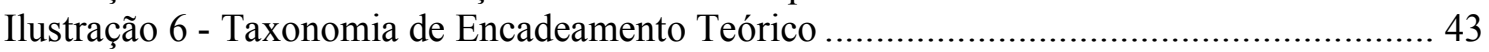

Ilustração 7 - Fundamentos da Teoria do Poder de Mercado................................................. 44

Ilustração 8 - Fundamentos da Teoria do Ciclo do Produto .................................................... 48

Ilustração 9 - Fundamentos da Teoria da Internalização .................................................. 49

Ilustração 10 - Fundamentos do Arcabouço do Paradigma Eclético......................................... 50

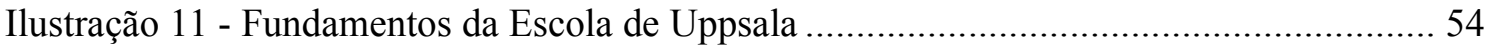

Ilustração 12 - Fundamentos da Escola Nórdica de Negócios Internacionais ....................... 59

Ilustração 13 - Fundamentos da Teoria sobre Competição e Competitividade Global ........... 61

Ilustração 14 - Fundamentos da Abordagem sobre Gestão Estratégica de Operações............ 68

Ilustração 15 - Fundamentos da Abordagem sobre Gestão de Competências ......................... 70

Ilustração 16 - Fundamentos da Abordagem sobre Gestão do Conhecimento ....................... 72

Ilustração 17 - Impulsionadores da internacionalização do varejo .................................... 83

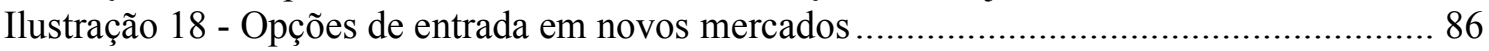

Ilustração 19 - Varejo e as teorias sobre internacionalização ............................................. 93

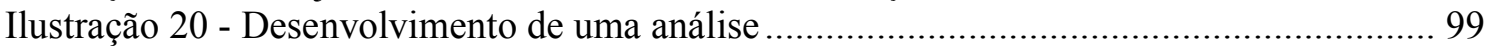

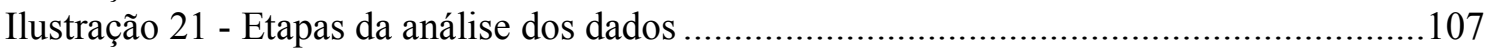

Ilustração 22 - Taxonomia resultado da análise dos dados..............................................171 


\section{O PROBLEMA DE PESQUISA}

\subsection{Introdução}

A década de 70 foi caracterizada por grande atividade de construtoras brasileiras no exterior, particularmente na África e no Oriente Médio. Nos anos 80, as organizações brasileiras destacaram-se pelo grande fluxo de investimentos realizados no exterior, e na década de 90 , em conseqüência da abertura comercial feita em nosso país, as empresas brasileiras foram buscar em outros países atualização tecnológica para enfrentar competidores estrangeiros. Esse movimento de internacionalização caracterizou-se principalmente pelo deslocamento de empresas do setor industrial, já que a internacionalização das empresas de varejo é um fenômeno mais recente (HILAL, HEMAIS, 2003; MAIA, 2003; PRUX, BRITTO, BIS, MEIRA, 2005).

No final dos anos 80 e princípio dos 90, as mudanças geopolíticas no Leste Europeu levaram à abertura desses mercados, que, conseqüentemente, viram um considerável aumento de interesse dos varejistas. Os mercados do Leste Asiático, por seu turno, ao mesmo tempo em que se tornavam acessíveis aos investidores externos, apresentavam pela primeira vez um crescimento expressivo e ofereciam novas oportunidades para investimentos (ALEXANDER, SILVA, 2002).

Já a década de 90 foi marcada por alterações nas oportunidades para os varejistas nos mercados globais e intensificação da concorrência nos mercados locais, a partir de uma orientação para mercados mais desenvolvidos, como o americano e o europeu, para lidar com os desafios dos mercados chamados emergentes. Há razões para essa mudança nas expansões internacionais, algumas associadas diretamente aos mercados emergentes e outras relacionadas às experiências anteriores de processos de internacionalização. As condições geopolíticas, econômicas e competitivas alteraram fundamentalmente a direção da expansão internacional. Apesar desse movimento, um grande número de varejistas europeus e americanos já havia explorado oportunidades de expansão em mercados desenvolvidos e vivenciado as dificuldades de se estabelecer em mercados competitivos onde os varejistas 
locais, bem-sucedidos, já tinham alcançado níveis avançados da estrutura do mercado (ALEXANDER, SILVA, 2002).

Nesse contexto, o aumento das atividades no mercado brasileiro aconteceu com a estabilização das condições econômicas a partir do Plano Real, em 1994, que gerou mudanças sociais como o crescimento de um mercado de classe média e da necessidade de estruturas de varejo mais desenvolvidas e capazes de satisfazer a crescente demanda dos consumidores. A estabilização de fatores econômicos favoreceu mudanças sociais e criou um ambiente mais propício para os varejistas (ALEXANDER, SILVA, 2002).

\subsection{Formulação do problema de pesquisa}

O problema de pesquisa desta tese é: qual a relação entre as teorias sobre internacionalização de empresas e o processo de expansão de empresas de varejo brasileiras para países estrangeiros?

\subsection{Objetivos do estudo}

O objetivo principal desta tese é identificar o que leva uma empresa a se deslocar para outros países, para onde se desloca (por que escolhe determinados locais em detrimento de outros), quais são os modos de entrada selecionados e como as empresas se adaptam aos novos locais, sob os conceitos de internacionalização de empresas.

O primeiro objetivo específico deste estudo é pesquisar dados secundários provenientes de teses, dissertações, artigos relacionados ao objetivo principal, disponibilizando as informações de forma ordenada. O segundo objetivo específico é propor uma Taxonomia de Encadeamento Teórico que organize as teorias relacionadas à internacionalização de empresas. O terceiro objetivo específico é aplicar o método de Análise de Conteúdo em pesquisa da área de Administração.

A fim de responder ao problema de pesquisa, realizou-se um estudo de campo para a obtenção de dados primários, com os gestores de dez empresas de varejo brasileiras. As empresas 
pesquisadas foram Arezzo, Carmen Steffens, Chilli Beans, Lilica Ripilica (Marisol), Morana, Mundo Verde, Nobel, O Boticário, Spoleto e Victor Hugo. Empregou-se o método de Análise de Conteúdo associado à Análise de Correspondência para identificar a relação entre as diversas abordagens teóricas sobre internacionalização das organizações e o processo de internacionalização verificado nas empresas de varejo pesquisadas.

\section{$1.4 \quad$ Justificativa do estudo}

\subsubsection{Globalização e internacionalização}

Uma das principais características do século 21 relaciona-se com o fenômeno da interconectividade entre os povos e as organizações no mundo. Essa interconectividade pode ser menor ou maior, de curta ou longa duração; pode ter a finalidade de promover interesses pessoais ou organizacionais e de atingir objetivos econômicos, culturais ou políticos. O resultado principal desse fenômeno é uma interdependência crescente entre ambientes humanos e físicos segmentados geograficamente. Embora o comércio eletrônico e a Internet sejam os indicadores fundamentais dessa globalização, há outros indicadores como as viagens, os meios de comunicação, a tecnologia, os fluxos financeiros e o movimento dos povos. Porém, poucas organizações públicas ou privadas são inteiramente globais em suas atividades. O panorama atual é marcado por (HITT, IRELAND, HOSKISSON, 2002; DUNNING, 2005):

a) aumento da interconectividade entre seres humanos e organizações, já que a interconectividade oferece um potencial para o progresso econômico e o relacionamento social entre os povos do mundo;

b) turbulência econômica e política, sendo a mudança, a volatilidade e a complexidade características gerais que vão além das regionais;

c) avanços contínuos em todos os tipos de conhecimento, com custos de comunicação em queda, fenômeno que está reconfigurando a economia e a vida diária;

d) aumento das tensões, uma vez que a globalização traz em si a convergência e a divergência, a uniformidade e a diversidade, a competição e a cooperação, a centralização e a descentralização, o individual e o comunitário, tudo ao mesmo tempo;

e) reavaliação de objetivos e índice do desenvolvimento humano, de modo que, comparando-se com o passado, mais atenção está sendo dada agora ao bem-estar social, 
cultural e ideológico dos indivíduos e das comunidades e também aos critérios de geração de riqueza;

f) posição das corporações globais e dos países cada vez mais dependente de seu sucesso no estabelecimento de parcerias estratégicas, no aprendizado fruto dessas parcerias e da participação em uma rede global de atividades;

g) influência cada vez maior das estruturas de incentivo dos países e das empresas nas atitudes societárias, no sentido de se criarem estratégias para o desenvolvimento econômico e a responsabilidade social de entidades privadas e públicas;

h) papel crescente dos múltiplos acionistas (stakeholders), tais como entidades do consumidor, acionistas e união de trabalhadores, que vêm influenciando a maneira de agir das organizações públicas ou privadas;

i) propagação geográfica da democracia econômica de mercado variando em intensidade, pois há graus distintos de intervenção governamental de ordem nacional e/ou internacional para proteção econômica, política ou social.

O contexto onde as firmas atuam se transformou consideravelmente nos últimos 50 anos e elas tiveram de mudar seu comportamento para sobreviver e prosperar na competitividade acirrada e no ambiente globalizado. Nota-se particularmente o surgimento de uma economia global, o crescimento de uma economia dos serviços, de uma economia dirigida pela Internet, de mercados de alta tecnologia e baseados no conhecimento das redes e dimensões da economia do valor. Por essa razão, as teorias precisam levar em conta esses novos comportamentos (AXINN, MATTHYSSENS, 2002; DUNNING, 2005).

A globalização da economia resulta da convergência de um grande número de outras mudanças que impulsionam o fenômeno da internacionalização (AXINN, MATTHYSSENS, 2002):

a) com origem na tecnologia, houve avanços em telecomunicações, promovendo comunicação mais rápida e efetiva dentro da firma e entre firmas, avanços nos transportes, facilitando o deslocamento de bens e pessoas dentro dos continentes e entre eles com velocidade, avanços nos processos de produção, facilitando a adaptação dos custos de produção;

b) uma significativa redução das barreiras de comércio ocorreu por meio da criação de acordos como Nafta (North American Free Trade Agreement ou Tratado Norte-Americano de Livre Comércio) e Mercosul (Mercado Comum do Sul) e de contínuas reduções de tarifas 
negociadas através do GATT (General Agreement on Tariffs and Trade ou Acordo Geral sobre Tarifas e Comércio) e da WTO (World Trade Organization ou Organização Mundial do Comércio);

c) internacionalização dos estilos de vida, que teve origem nos processos de globalização;

d) os negócios por meio da Internet estão alterando o formato dos mercados e dos controles, o que leva ao questionamento das abordagens de marketing, administração e internacionalização, pois a Internet permite que comerciantes internacionais tenham economia nos custos, penetração mais rápida nos mercados e transporte mais ágil de bens e serviços, adicionando-se o fato de os comerciantes poderem acessar com mais facilidade os bancos de dados dos atuais consumidores e as informações das pesquisas de mercado, bem como se conectarem mais facilmente com possíveis parceiros;

e) por meio da Internet muitas empresas de pequeno e médio porte podem vencer as tradicionais barreiras à exportação ou participação nos negócios internacionais, uma vez que as empresas desse porte que não possuem canais de distribuição no exterior podem usar a Internet para vender em novos mercados. Por outro lado, a Internet promove aos compradores o acesso a uma variedade de vendedores, e mesmo que a compra não se dê pela Internet o acesso às informações de possíveis fornecedores se dará;

f) outro impacto da Internet se verifica nos processos internos da firma, pois a rede mundial possibilita o desenvolvimento de times virtuais e facilita o compartilhamento de conhecimento dentro das firmas e entre elas, o que impacta na colaboração e na concorrência global.

As empresas têm sido forçadas cada vez mais a gerar valor para seus consumidores e acionistas. Os compradores na economia de hoje, especialmente os empresariais, esperam pacotes de valor de seus fornecedores e, ao mesmo tempo, vasculham os mercados mundiais em busca de menores preços. Também os consumidores esperam melhores pacotes de valor das empresas com as quais se relacionam, além de procurarem mais valor por menor preço. Os consumidores estão crescentemente preferindo produtos ambientalmente responsáveis ou serviços de empresas que claramente os valorizam como indivíduos. Esses desafios criam um novo tipo de tensão nas firmas que se expandem internacionalmente, e requerem novos tipos de solução. São tidas como questões-chave a organização e disponibilidade dos serviços mundialmente, a coordenação de preços, a uniformidade da reputação e a colaboração com as outras partes para a criação de valor na cadeia (AXINN, MATTHYSSENS, 2002). 
A crescente ênfase nos valores para os acionistas força as empresas a monitorarem ao mesmo tempo os custos e a criação de valor, pois mais do que nunca os investimentos internacionais são avaliados em termos da capacidade que têm de gerar imediato retorno e fluxo de capital (AXINN, MATTHYSSENS, 2002).

Em suma, no mundo atual o fator humano e o ambiente físico têm de fazer parte das estratégias das corporações e das políticas de governos. O panorama econômico, político, social e cultural acaba por forçar mudanças nas estruturas empresarias. Essa é a realidade das empresas que atuam no mercado nacional ou internacional, ou que iniciarão suas atividades nesse contexto.

\subsubsection{Motivos, estratégias e riscos da internacionalização}

A internacionalização de empresas é um processo que pode ser classificado em dois tipos: para dentro (inward) e para fora (outward). Internacionalização para dentro é o nome dado a processos de importação, obtenção de licenças ou franquias e aquisição de tecnologia. A internacionalização por meio de exportação, concessão de licenças ou franquias e investimento direto no exterior chama-se internacionalização para fora (BARRETTO, ROCHA, 2003).

Barretto e Rocha (2003) afirmam que um primeiro conjunto de motivações para a internacionalização de empresas foi apresentado por Hymer em seu trabalho The International Operations of National Firms: A Study of Foreign Direct Investment, de 1976. As razões para a internacionalização seriam a neutralização dos concorrentes, a exploração de vantagens competitivas e a necessidade de se diversificar (HYMER, 1976). A tomada de decisão aconteceria como resultado da avaliação feita pela empresa numa condição de racionalidade limitada, como proposto na Teoria dos Custos de Transação, e em um processo decisório com componentes de subjetividade guiados por maior ou menor grau de racionalidade, conforme a Escola de Uppsala (BARRETTO, ROCHA, 2003; KUTSCHKER, BÄURLE, 1997).

Loureiro (1990) explica que as empresas internacionalizam seus negócios por três motivos: marcar presença em função da ação ou existência de empresas concorrentes no país, reduzir os custos e ampliar competências. Para Cerceau e Lara (1999), os objetivos mais comumente desejados com a internacionalização são o crescimento no volume de negócios, a melhoria da 
rentabilidade a curto e longo prazo, a invulnerabilidade futura e o equilíbrio da carteira estratégica. Segundo os autores, há quatro motivos principais para a internacionalização de empresas (CERCEAU, LARA, 1999): evolução da capacidade de exportar, conseqüência de vantagens competitivas no mercado doméstico; procura de competitividade tecnológica, conseqüência de exposição internacional.

Para Ricupero e Barreto (2007), as causas da tendência de internacionalização de empresas são:

a) buscar recursos, mercados e tecnologia;

b) enfrentar as condições de concorrência em economia mundial cada vez mais unificada;

c) manter os mercados internos;

d) expandir os negócios no mercado internacional;

e) fortalecer o poder de competição por estar próximo do mercado consumidor;

f) aproveitar as vantagens dos blocos econômicos;

g) usufruir as fontes internacionais de financiamento;

h) ultrapassar barreiras protecionistas;

i) acessar rede de fornecedores.

Os autores destacam que há, entretanto, a possibilidade de resultados negativos do processo de internacionalização como exportação de empregos, prejuízo na balança de pagamentos em função da saída de divisas e redução dos níveis de investimento doméstico (RICUPERO, BARRETO, 2007).

Para Loureiro (1990), são diversos os critérios de escolha do país onde será estabelecido o negócio. Em termos econômicos, o produto nacional bruto, a renda nacional, a inflação, o nível de emprego, a renda per capita, o nível de consumo por habitante e a taxa de crescimento são fatores que intervêm na escolha. Quanto à balança de pagamentos, levam-se em consideração a evolução de posições e os saldos de pagamentos, além da dependência de receitas de exportação e taxa de câmbio. Os riscos políticos - representados pela composição étnica, lingüística e religiosa, o regime político, a incidência de revoluções e guerras - e o nível de vida (renda por habitante, hábitos de consumo, existência de infra-estrutura) pesam na seleção do país, ao lado do custo - disponibilidade de recursos energéticos, matéria-prima, recursos humanos, fornecedores, tarifário, tributário. Os fatores sociais (qualificação de mãode-obra, encargos sociais, sindicalização) também desempenham um papel nessa escolha, 
além de fatores fiscais e jurídicos (impostos, taxações, tributação, regulamentação, legislação) e das relações com parceiros locais.

Segundo o mesmo autor, as empresas utilizam duas macroestratégias de internacionalização. A primeira é voltada para a internacionalização sem investimento direto no exterior:

a) acordo de licença, que pode ocorrer de distintas formas - para fabricação de produtos, utilização de serviços, uso de marcas ou distribuição - e, como o próprio nome diz, consiste em dar a permissão para produção ou distribuição de bens ou serviços, bem como utilização de marcas por outras empresas por meio de contratos;

b) exportação;

c) franquia, que consiste em um acordo no qual uma das partes - o franqueador disponibiliza marca, competências, sistema de gestão, serviços para outra parte - o franqueado -, a qual, por sua vez, fornece o capital para o estabelecimento do negócio e obedece aos parâmetros de gestão e marca determinados pelo franqueador. É o sistema pelo qual um franqueador cede ao franqueado o direito de uso de marca ou patente, associado ao direito de distribuição exclusiva ou semi-exclusiva de produtos ou serviços e, eventualmente, também ao direito de uso de tecnologia de implantação e administração de negócio ou sistema operacional desenvolvido ou detido pelo franqueador, mediante remuneração direta ou indireta, sem que, no entanto, fique caracterizado vínculo empregatício;

d) contrato de gestão, em que uma empresa se compromete a gerir parte ou a totalidade das operações de outra, em troca de rendimentos fixos ou participação nos lucros.

A segunda macroestratégia de internacionalização consiste em investimento direto no exterior:

a) subsidiária comercial, ou seja, uma empresa criada em outro país para distribuição, estocagem ou comercialização de produtos ou serviços, sendo a totalidade do capital investido originária da empresa matriz;

b) subsidiária produção, situação em que a totalidade do capital investido é originária da empresa matriz e a empresa criada em outro país produz parte ou a totalidade de produtos ou serviços ou ainda parte dos insumos necessários;

c) subsidiária mista, caracterizada por ser empresa criada em outro país com $100 \%$ do capital da matriz e que pode operar tanto em atividades de produção quanto comerciais;

d) joint-venture, que é a associação entre empresas por integração de partes de cada uma para compartilhamento estratégico e desenvolvimento de competências; 
e) projeto especial, ou a presença da empresa em outro país em função de um projeto específico e por tempo determinado, após o qual deixa o país, mas pode retornar em função de algum outro projeto.

Loureiro (1990) destaca também os riscos existentes nos processos de internacionalização, que podem ser de natureza política, econômica (incluindo cambial), social, cultural, regulatória (legislativa e jurídica), ambiental, comercial (competitiva e estratégica) e financeira.

Cerceau e Lara (1999) trazem para a análise das estratégias adotadas pelas empresas no processo de internacionalização a questão da aprendizagem. Segundo os autores, a escolha da estratégia de internacionalização depende principalmente de experiências vividas pela empresa no passado e de vantagens competitivas presentes, vinculadas à realidade e aos aspectos culturais, econômicos, sociais e políticos do país de origem. Os fatores que interferem no processo de internacionalização são riscos de diversas naturezas, tais como: regulamentação governamental, competição no mercado, infra-estrutura local, objetivos da organização, necessidade de controle, recursos internos, bens e capacidades, flexibilidade para se adaptar aos consumidores, aos mercados e ao ambiente.

Conseqüentemente, os modos de entrada em novos locais podem ser a exportação, os acordos contratuais (licenciamento, franquia ou contrato de manufatura) e investimentos internacionais diretos - joint-ventures, controle total da subsidiária (controle acionário) ou alianças estratégicas (CERCEAU, LARA, 1999).

Para Cyrino e Barcellos (2007), os benefícios da internacionalização de empresas podem ser descritos como:

a) relacionados à expansão de mercados - maior capacidade de resposta para os clientes internacionais, fortalecimento da posição competitiva, diversificação geográfica, redução de ricos e fortalecimento da imagem da marca domesticamente;

b) relacionados à melhoria de eficiência - economia de escala e de escopo, acesso a recursos, acesso a menores custos e aproveitamento de imperfeições de mercado para realizar ganhos;

c) relacionados à aprendizagem - acumulação de conhecimento, desenvolvimento de competências empresariais existentes e aquisição de novas competências. 
Cyrino e Barcellos (2007) afirmam que há, por outro lado, custos e riscos inerentes ao processo de internacionalização, quais sejam: custos crescentes de coordenação e governança; desvantagens relacionadas ao fato de a empresa ser nova no local; riscos políticos e econômicos; desvantagens relativas ao fato de ser uma empresa estrangeira, sobre a qual pesa o desconhecimento e a dificuldade de lidar com o contexto do mercado e o panorama cultural, além da imagem de marca associada ao país de origem.

Os autores chamam a atenção para o impacto da internacionalização sobre os resultados da empresa. Verificam-se três principais estágios no processo de internacionalização. O primeiro é marcado pelo baixo grau de internacionalização e, conseqüentemente, custos que superam as receitas. O segundo estágio é aquele em que a empresa já implantou um maior número de operações fora do país e está desenvolvendo conhecimento internacional. Essa é a fase da aprendizagem e o momento em que a empresa tem custos marginais que tendem a se reduzir para aumentar as receitas marginais, até atingir o ponto máximo, em que os resultados da internacionalização são positivos. O terceiro e último estágio é aquele em que a empresa passa novamente a apresentar resultados negativos em função do aumento do número de operações internacionais e conseqüente aumento dos custos (CYRINO, BARCELLOS, 2007).

O levantamento, a análise e avaliação incompletos ou equivocados de qualquer desses fatores pode torná-los uma barreira para a internacionalização da empresa e o sucesso de suas atividades no novo país (LOUREIRO, 1990). Hilal e Hemais (2004) destacam que firmas diferentes possuem características próprias que podem levar a percepções distintas das oportunidades e ameaças existentes no exterior e ao longo do tempo.

\subsubsection{Internacionalização de empresas brasileiras}

A participação brasileira em mercados internacionais teve origem em tempos coloniais, com a indústria extrativista de recursos naturais e o baixo custo de mão-de-obra, características que foram mantidas até o início da década de 60. Nesse período, a produção manufatureira destinava-se exclusivamente ao consumo do mercado local. Foi só entre as décadas de 60 e 70 que as empresas brasileiras iniciaram seu processo de internacionalização, por meio da exportação de excedentes de produção, fato que decorreu das políticas de substituição de importação que emergiram nessa época. Na década de 80, esse processo perdeu força, mas foi retomado no decênio seguinte, em virtude da abertura de mercado, estabilização da economia 
e entrada de novos concorrentes no mercado brasileiro (CYRINO, BARCELLOS, 2006; BARRETTO, ROCHA, 2003). A partir da década de 90, iniciou-se a formação de acordos bilaterais e a criação do Mercosul. A consolidação desse mercado introduziu novas variáveis no planejamento estratégico das empresas brasileiras: primeiramente, os produtos precisavam ser repensados para servir a um mercado maior e nem sempre homogêneo; em segundo lugar, as empresas teriam de atuar como multinacionais para conseguir capturar os benefícios desse mercado (GOUVEA, 1998).

O Mercosul vem cumprindo o papel de criar um ambiente para o envolvimento das empresas brasileiras em mercados externos, funcionando como um laboratório para o treinamento das empresas locais e favorecendo o desenvolvimento de estratégias e habilidades necessárias para a internacionalização de empresas brasileiras. Como resultado, em 1998, mais de 900 empresas brasileiras de diversos setores atuavam em mercados internacionais (GOUVEA, 1998; PRUX, BRITTO, BIS, MEIRA, 2005). Cresceram os investimentos diretos e o comércio estrangeiro entre os membros do Mercosul, e o tamanho do mercado, juntamente com a estratégia de abertura e as baixas taxas de inflação, vem favorecendo o desenvolvimento e crescimento da região (GOUVEA, 1998).

As empresas do Mercosul estão expandindo suas operações e utilizando diversos modos de entrada. Apesar da proximidade cultural e geográfica, várias empresas brasileiras estão tendo cuidado em suas abordagens, utilizando distribuidores, licenciamentos, franquias e jointventures como modos de entrada. O sistema de franquia brasileiro é outra estratégia de entrada para rápida expansão. No início dos anos 90, firmas como a Localiza, de aluguel de carros, iniciou sua operação internacional no mercado argentino. Após dois anos de pesquisas, entrou no mercado por meio de aliança estratégica com investidores locais. Atualmente, a Localiza possui filiais na Bolívia, no Uruguai, Paraguai, Peru, Equador e Chile. Outra empresa de locação de carros, a Unidas, seguiu os passos da Localiza, estabelecendo filiais na Argentina, no Uruguai e no Chile (GOUVEA, 1998).

Muitas empresas empregaram a estratégia de entrada de $100 \%$ de investimento próprio. No caso da indústria de bebidas, a Brahma investiu US\$ 120 milhões em uma planta de produção em Lujan, na Argentina. A Cofap, uma empresa de componentes para carros, adquiriu na Argentina a empresa Indufren, transformando-se na líder do setor nesse país. Em alguns 
casos, as empresas brasileiras optaram pela aquisição de plantas já existentes; em outros, decidiram pela construção de novas plantas (GOUVEA, 1998).

O panorama está mudando rapidamente. O volume do capital de empresas brasileiras investido no exterior alcançou US\$ 70,7 bilhões no fim de 2004, acima dos US\$ 54,9 bilhões de 2003, de acordo com o Banco Central. Uma quantidade crescente de empresas faz empréstimos para constituir subsidiárias no exterior. Uma medida aproximada do investimento direto chegou a US\$ 15,2 bilhões em 2004, maior US\$10,1 bilhões em relação ao ano anterior (Selling Perfumes in Paris, 2005).

Os serviços financeiros também estão abrindo negócios no exterior. O Banco do Brasil lançou o Banco do Brasil Seguradora, em Nova York, uma agência para prestar serviços às empresas brasileiras nos mercados de Nova York e Chicago. O banco já teve uma agência similar para oferecer serviços em Londres, e desde 1960 construiu uma rede com 38 unidades no exterior, que retém US\$ 21 bilhões do total dos recursos fora do Brasil. Segundo o banco, sua atuação internacional está projetada para seguir o mapa do comércio brasileiro no exterior, de modo que abrir a agência em Nova York é uma clara conseqüência dos laços internacionais crescentes de empresas brasileiras (Selling Perfumes in Paris, 2005).

\subsubsection{Fatores que interferem na internacionalização de empresas brasileiras}

Uma das razões que levaram à internacionalização de empresas brasileiras foi a percepção dos blocos da América Latina a respeito das políticas e estratégias que foram estabelecidas para fortalecer as economias domésticas e melhorar suas posições em relação à economia global. Para Gouvea (1998), a abertura dos mercados, a implementação de políticas monetárias e fiscais e as estratégias de privatização reduziram drasticamente a inflação. Como conseqüência, fortaleceu-se o ambiente competitivo doméstico. Esses fatores associados aos acordos em mercados regionais estimularam empresas brasileiras a desenharem estratégias de internacionalização, acompanhando o movimento de inúmeras multinacionais estrangeiras. Além dos fatores relativos ao ambiente de negócios, os laços culturais e étnicos e as economias de escala aparecem como os principais impulsionadores da internacionalização das empresas brasileiras no Mercosul (GOUVEA, 1998). 
A partir de um estudo realizado por Silva e Rocha (2001), dez obstáculos para a exportação de empresas brasileiras foram identificados como mais importantes: 1) incentivos inadequados à exportação; 2) grande concorrência no mercado-alvo; 3) políticas de taxa de câmbio inadequadas; 4) altos custos de transporte e seguro; 5) exigências burocráticas brasileiras; 6) lento movimento de pagamentos no exterior; 7) falta de suporte financeiro para as empresas; 8) exigências burocráticas de outros países do Mercosul; 9) exigências de qualidade do mercado-alvo; 10) falta de conhecimento sobre os mercados potenciais. Observa-se que os obstáculos mais informados pelos exportadores do Mercosul são fundamentalmente externos à firma. Os gestores tendem a não aceitar a responsabilidade pelas dificuldades de exportação enfrentadas pelas empresas e as atribuem a causas externas, que não estão sob seu controle (SILVA, ROCHA, 2001).

A corrupção - tanto no Brasil quanto nos outros países - foi considerada a barreira mais importante à exportação de empresas grandes, com experiência na operação de exportação para diferentes regiões do mundo. A corrupção no Brasil foi vista por $30 \%$ das firmas como importante ou muito importante; 13\% das firmas destacaram a corrupção nos outros países. Isso sugere que determinados tipos de empresas são mais sensíveis à corrupção do que outros (SILVA, ROCHA, 2001).

As restrições políticas e econômicas são percebidas como fator relevante para as empresas com maior experiência em exportação e com larga atuação geográfica. Já a falta de competitividade no mercado-alvo aparece afetando mais as indústrias voltadas à produção de bens para outras indústrias (B2B) do que aquelas produtoras de bens para o consumidor final (B2C). Esses fatores relacionam-se mais às especificidades do mercado, sugerindo que os obstáculos podem ser percebidos de maneira diferente, dependendo do destino da exportação (SILVA, ROCHA, 2001).

Segundo Cyrino e Barcellos (2006), as razões que impulsionam a internacionalização das empresas brasileiras podem ter origem em fatores macroeconômicos e microeconômicos:
a) necessidade de expansão para novos mercados;
b) utilização mais eficiente dos recursos da empresa à luz de oportunidades produtivas disponíveis no mercado;
c) busca de maior controle dos canais de distribuição;
d) maior proximidade com consumidores finais; 
e) diversificação de riscos em função das mudanças das políticas institucionais e das condições macroeconômicas do país;

f) resposta à concorrência global;

g) busca de alternativas para redução de custos;

h) intenção estratégica de dirigentes e fundadores da empresa.

Rocha (2003) chama a atenção também para os fatores que, combinados, podem explicar a não-internacionalização das empresas brasileiras:

a) fator geográfico, ou seja, o país é distante fisicamente da Europa e dos Estados Unidos;

b) fator ambiental, ou a existência, internamente ao país, de incentivos fiscais, facilidade para financiamentos, questões cambiais ou outros incentivos governamentais, e, externamente, os fatores macroambientais;

c) fator motivacional, já que poucas empresas se dispõem a sair para outros países, a não ser que as condições do mercado interno acabem por estimulá-las, caso em que saem em virtude de saturação do mercado, incentivos governamentais ou pedidos provenientes do exterior. Mas diversas empresas abandonam a atuação internacional em razão da falta de competitividade em mercados externos; por outro lado, a existência de um amplo mercado interno também pode ser um fator para não se internacionalizar;

d) fator cultural, uma vez que a particularidade cultural brasileira incorre em dois comportamentos que dificultam a internacionalização de empresas, quais sejam a percepção de distância psicológica ou cultural entre brasileiros e outros povos e a forma como os brasileiros medem essa distância, pela estrutura familiar.

Para Barretto e Rocha (2003), há uma variedade de motivos que levam uma empresa brasileira a se internacionalizar:

a) recebimento de pedidos inesperados do exterior por parte de uma empresa ou indivíduo;

b) crescimento, geralmente quando o mercado interno está saturado ou é muito custoso ampliar a participação da empresa nesse mercado;

c) consolidação, relacionada à necessidade de atender os clientes no exterior;

d) sobrevivência, quando a empresa defronta-se com a possibilidade de deixar de existir caso não internacionalize sua operação, em função do acirramento da concorrência e/ou entrada de novas empresas no mercado local ou internacional;

e) identificação de oportunidades internacionais de negócio para a empresa;

f) estratégia de negócio da empresa inclui a intenção de expansão internacional. 
Além dos fatores já relacionados, há a questão da imagem. A representação do Brasil nos mercados altamente consumidores no mundo atual não é de um produtor de tecnologia, produtos confiáveis ou atividades que gerem orgulho, que envaideçam seus moradores ou provoquem uma necessidade de identificação por parte de outros. As empresas brasileiras, na maioria das vezes, entram em um processo de internacionalização tentando se apoiar em vantagens competitivas que conseguiram consolidar no país de origem. Como esses diferenciais competitivos não são percebidos lá fora por falta de divulgação e, por conseguinte, não há consolidação da imagem percebida internamente, os consumidores simplesmente não conhecem essas empresas e, portanto, não associam seus nomes aos impulsos estratégicos (MELLO, MIRANDA, VILELA, s.d.).

Os fatores que interferem no processo de internacionalização das empresas brasileiras atuam de modo conjunto e variam ao longo do tempo. Assim sendo, verificam-se períodos em que as condições resultantes são distintas, bem como o processo de internacionalização, como se pode ver na Ilustração 1, proposta por Rocha (2003).

Tesfom e Lutz (2006) demonstram que as barreiras que interferem nas exportações de países desenvolvidos e em desenvolvimento apresentam semelhanças e diferenças na maneira como intervêm em cada caso. As barreiras podem ser empresariais, dos produtos, da indústria e do ambiente (macro). No caso dos países desenvolvidos, verificam-se forças internas à empresa e forças externas, ligadas ao ambiente onde atuam. As forças internas são as próprias características da empresa e de seus produtos. As forças externas são as características da indústria, de exportação do mercado e os macrofatores do ambiente. Os fatores combinados definem a estratégia de exportação de marketing, que podem ser individuais ou por meio de cooperação. 


\begin{tabular}{|c|c|c|}
\hline Fatores ambientais & Fatores motivacionais & Impactos na internacionalização \\
\hline $\begin{array}{l}\text { Décadas de } 60 \text { e } 70 \\
\text { - Forte crescimento da economia } \\
\text { brasileira } \\
\text { - Grande expansão do comércio } \\
\text { internacional } \\
\text { - Política governamental de } \\
\text { promoção da exportação }\end{array}$ & $\begin{array}{l}\text { - Pedidos inesperados do exterior } \\
\text { - Incentivos governamentais }\end{array}$ & $\begin{array}{l}\text {-Estímulo à internacionalização via } \\
\text { exportação }\end{array}$ \\
\hline $\begin{array}{l}\text { Década de } 80 \\
\text { - Recessão internacional } \\
\text { - Expansão do Japão e dos Tigres } \\
\text { Asiáticos } \\
\text { - Recessão, década perdida } \\
\text { - Fechamento da economia }\end{array}$ & $\begin{array}{l}\text { - Escasseiam-se os pedidos do } \\
\text { exterior } \\
\text { - Os pedidos vão para a Ásia } \\
\text { - Escasseiam-se os incentivos à } \\
\text { exportação } \\
\text { - Falta competitividade aos } \\
\text { produtos brasileiros }\end{array}$ & $\begin{array}{l}\text { - Freio à internacionalização via } \\
\text { exportação }\end{array}$ \\
\hline $\begin{array}{l}\text { Década de 90: até } 1995 \\
\text { - Abertura de mercado e entrada } \\
\text { de concorrentes } \\
\text { - Criação do Mercosul }\end{array}$ & $\begin{array}{l}\text { - Aumenta percepção de risco no } \\
\text { mercado doméstico } \\
\text { - Expansão do contexto de } \\
\text { referência } \\
\text { - Abertura psicológica a novos } \\
\text { mercados }\end{array}$ & $\begin{array}{l}\text {-Estímulo ao investimento direto no } \\
\text { exterior }\end{array}$ \\
\hline $\begin{array}{l}\text { Década de 90: 1995-1998 } \\
\text { - Expansão do mercado interno } \\
\text { - Política cambial de } \\
\text { sobrevalorização do real }\end{array}$ & $\begin{array}{l}\text { - Aumenta atratividade do mercado } \\
\text { doméstico } \\
\text { - Falta de competitividade das } \\
\text { exportações }\end{array}$ & $\begin{array}{l}\text { - Freio à internacionalização via } \\
\text { exportação } \\
\text { - Estímulo ao investimento direto no } \\
\text { exterior }\end{array}$ \\
\hline $\begin{array}{l}\text { Década de 90: 1998-2000 } \\
\text { - Crise cambial de } 1999 \\
\text { (desvalorização do real) }\end{array}$ & $\begin{array}{l}\text { - Aumenta competitividade dos } \\
\text { produtos brasileiros no exterior }\end{array}$ & $\begin{array}{l}\text { - Estímulo à internacionalização via } \\
\text { exportação } \\
\text { - Freio ao investimento direto no } \\
\text { exterior }\end{array}$ \\
\hline
\end{tabular}

Ilustração 1 - A conexão entre fatores ambientais e fatores motivacionais na internacionalização das empresas

FONTE: ROCHA, 2003, p. 21.

No caso das empresas de países em desenvolvimento, também os fatores internos à empresa e relativos ao meio ambiente determinam sua exportação. Relativamente ao Brasil, os autores destacam como barreiras internas ligadas à empresa (TESFOM, LUTZ, 2006):

a) conhecimento e informação de marketing, ou seja, falta de conhecimento a respeito dos mercados exportadores e de exportação, falta de conhecimento em exportação, informações 
inadequadas, habilidade de identificar consumidores ou compradores em países estrangeiros, representação inadequada nos países estrangeiros ou dificuldade de localizar agentes e distribuidores adequados;

b) falta de recursos financeiros para conduzir pesquisa de mercado no exterior e orçamento de marketing inadequado;

c) recursos humanos caracterizados por falha de foco gerencial e comprometimento para se desenvolverem atividades de exportação, além de falta de capacidade gerencial.

As barreiras internas ligadas ao produto são (TESFOM, LUTZ, 2006):

a) baixa qualidade do produto, com ciclo de vida curto e sensível à moda;

b) capacidade de adaptação técnica insuficiente, com baixa qualidade dos controles técnicos e da matéria-prima, além de falta de experiência para se adaptar e diversificar os produtos.

As barreiras externas ou ambientais (macro) relativas à indústria são (TESFOM, LUTZ, 2006):

a) a estrutura, que se refere ao tamanho da firma, alta concentração da indústria e falta de tecnologia;

b) a concorrência, representada pelo preço e a existência de concorrentes agressivos.

As barreiras externas de mercado são (TESFOM, LUTZ, 2006):

a) os consumidores, sujeitos à imagem do produto nos mercados estrangeiros, com pouca demanda externa e efeito "país de origem";

b) os procedimentos, como a documentação de exportação e de trabalho.

Por fim, as barreiras do microambiente podem ser diretamente ligadas à exportação, como protecionismo, regulamentação de mercados estrangeiros, serviços de transporte e infraestrutura, falta de promoção de exportação e de programas patrocinados pelo governo e alocações cambiais. Também podem ser indiretamente ligadas à exportação, no caso das incertezas cambiais e de taxas de juros, política de taxa de câmbio, acordos internacionais, taxas de câmbio irreais (TESFOM, LUTZ, 2006). 


\subsubsection{Desafios e tendências}

A história recente da realidade empresarial brasileira tem sido intensamente afetada pela turbulência e as mudanças. Durante o período compreendido entre 1990 e 2000, o país consolidou as instituições políticas, globalizou a economia, abriu-se para a competição internacional e chegou à estabilidade econômica. Conseqüentemente, quatro tendências predominam no cenário dos negócios (FISCHER, EBOLI, 2000):

a) globalização da economia doméstica, pois os negócios se integraram e se tornaram interdependentes na economia mundial;

b) internacionalização das empresas brasileiras, uma vez que se expandiram, além dos domínios do Mercosul, para África, Europa e Estados Unidos;

c) privatização, programa que está se consolidando e cuja implementação não só reduz a participação do Estado na economia como também atrai investidores internacionais para estabelecer parcerias nos setores domésticos, afora a abertura do mercado para setores que anteriormente eram considerados serviços públicos, como energia elétrica e telecomunicações;

d) fusões, aquisição e associações, dado que as empresas procuram sinergia e habilidade colaborativa para ganhar competitividade, e para tal torna-se necessário desenvolver redes de relacionamento com outras empresas que possam agregar valor ao negócio, como fornecedores, agentes financeiros, clientes, comunidade ou mesmo os concorrentes.

O processo de internacionalização de empresas brasileiras é mais recente em comparação com o processo de internacionalização de empresas em outros países, principalmente os mais desenvolvidos, apesar de se identificarem iniciativas desde a década de 70. Acredita-se que cada vez mais empresas brasileiras se internacionalizarão. Por essa razão, torna-se imperativo compreender o fenômeno, a fim de fornecer informações para que outras empresas possam ampliar sua atuação em novos mercados internos (em seu país de origem) ou no exterior.

Este documento apresenta, no capítulo 1, o problema de pesquisa e o contexto onde a internacionalização de empresas se dá. O capítulo 2 traz o embasamento teórico sobre o tema e o capítulo 3, a metodologia de pesquisa empregada para o desenvolvimento da investigação empírica. Ao capítulo 4 cabe a análise dos dados e ao capítulo 5, as conclusões, limitações do estudo e sugestões para pesquisas futuras. 


\section{FUNDAMENTAÇÃO TEÓRICA}

\subsection{Introdução}

Este capítulo abrange, em sua primeira parte, as teorias e abordagens sobre a internacionalização das empresas de modo geral. A segunda parte destina-se às teorias e abordagens sobre a internacionalização de empresas de varejo.

Pode-se definir internacionalização como o processo por meio do qual a empresa começa a operar fora do seu mercado de origem (HITT, IRELAND, HOSKISSON, 2002). A internacionalização pode ser entendida como diferentes modos de atuar no exterior, que abrangem desde exportação indireta, exportação direta, passando por licenciamento, jointventures, alianças e aquisições, até investimento direto estrangeiro (ROOT, 1998).

Diversas estruturas conceituais têm sido usadas para explicar a dinâmica da internacionalização. Verifica-se uma multiplicidade de proposições de estruturas nas teorias e abordagens de distintos autores: variam em relação ao número de teorias ou abordagens conceituadas, sua classificação e o relacionamento entre elas. Diversos estudos sobre internacionalização têm sido realizados no âmbito das pesquisas acadêmicas nacionais e internacionais; entretanto, a maioria se concentra em adotar uma parcela das teorias para explicar a internacionalização da empresa.

Kutschker e Bäurle (1997) propõem um modelo composto de quatro dimensões para classificar as diversas estratégias de internacionalização, enfatizando o aspecto dinâmico desse fenômeno, conferido por sua quarta dimensão. As três primeiras dimensões são estáticas. A primeira é a quantidade e distância geográfico-cultural de cada país, ou seja, quantidade de países onde a empresa está operando. A segunda é o valor adicionado (value added), que se relaciona com os diferentes graus de envolvimento em um país, desde a atuação por meio da exportação até o estabelecimento de uma subsidiária própria, de modo que o valor adicionado pode estar nas atividades de comércio, pesquisa e desenvolvimento, produção, logística e vendas. A terceira é a integração, representada pelo grau de interação ou 
coordenação entre a matriz e as operações em outros países. A quarta dimensão - o tempo confere a mobilidade necessária ao modelo.

Whitelock (2002) sugere que quatro teorias fornecem os elementos-chave para uma apresentação realista e compreensível das decisões sobre os modos de entrada, por ele denominada abordagem estratégica de negócios (business strategy approach). A expansão estrangeira baseia-se em contingência e resulta da escolha que se faz entre as estratégias de expansão externa, guiada pela natureza das oportunidades do mercado, recursos da firma e filosofia gerencial. As quatro teorias que fornecem os elementos-chave são:

a) Modelo de Uppsala, que inclui a distância psíquica (J. Johanson; J.-E. Vahlne);

b) Paradigma Eclético, em função de abordar as vantagens OLI (J. Dunning);

c) Análise dos Custos de Transação, por considerar os recursos e as especificidades dos ativos (E. Anderson; H. Gatignon; A.T. Coughlan; R.F. Dwyer; S. Oh);

d) Redes Industriais de Relacionamento, pois leva em conta os relacionamentos no país estrangeiro (P.W. Turnbull; S. Ellwood; M.T. Cunningham).

Borini, Coelho, Ribeiro e Proença (2004) agrupam as teorias em dois blocos, tendo como base a proposição de Whitelock (2002). O primeiro bloco traz as teorias econômicas e o outro, as teorias comportamentais:

I - Teorias Econômicas:

a) Internalização (P. Buckley; M. Casson; A. Rugman);

b) Custos de Transação (O. Williamson);

c) Paradigma Eclético (J. Dunning);

d) Organização Industrial (S. Hymer; R. Caves);

e) Ciclo de Vida do Produto (R. Vernon);

f) Teoria da Vantagem Competitiva (M. Porter);

II - Teorias Comportamentais:

a) Escola de Uppsala (J. Johanson; J-E. Vahlne);

b) Teoria das Redes Industriais (U. Anderson; M. Forsgren; U. Holm; J. Johanson; G. Mattson).

Hemais e Hilal (2004) organizam as teorias sobre o processo de internacionalização da firma, separando-as segundo o enfoque econômico ou organizacional:

I - Enfoque econômico: 
a) Poder de Mercado (S. Hymer);

b) Ciclo do Produto (R. Vernon);

c) Internalização (P. Buckley; M. Casson);

d) Paradigma Eclético (J. Dunning);

II - Enfoque organizacional:

a) Escola de Uppsala (J. Johanson);

b) Escola Nórdica (S. Anderson).

Segundo Hemais e Hilal (2004), as teorias econômicas privilegiam os aspectos macroeconômicos nacionais e internacionais e se baseiam nas teorias do comércio, de localização, do balanço de pagamentos e nos efeitos das taxas de câmbio. Em termos de internacionalização, as teorias do Poder de Mercado, do Ciclo do Produto, da Internalização e o Paradigma Eclético focalizam o homem econômico, que tem acesso perfeito às informações e escolhe uma solução de forma racional. Esse enfoque é importante para definir como se desenvolvem as unidades produtivas durante as etapas posteriores de estabelecimento da firma no exterior; contudo, ignora os aspectos relacionados ao processo de internacionalização.

As teorias que privilegiam o enfoque organizacional incluem o Modelo de Uppsala, com foco em processos e, mais tarde, em networks, além das diversas vertentes da Escola Nórdica de Internacionalização da Firma. Nesses casos, o foco recai sobre o homem comportamental e o processo de internacionalização. Contudo, nem o enfoque econômico nem o enfoque organizacional consideram o fato de os indivíduos poderem fazer escolhas estratégicas (HEMAIS, HILAL, 2004).

As teorias de internacionalização são ordenadas segundo os enfoques econômico e organizacional em um panorama das relações conceituais existentes entre elas (Ilustrações 2 e $3)$.

Eckert e Mayrhofer (2005) propõem uma estrutura que tem por base o modelo desenvolvido por Kutschker e Bäurle (1997), no qual três dimensões fundamentais são analisadas sob a ótica de uma quarta, o tempo. Essa estrutura divide em três categorias cada processo de internacionalização: evolução internacional, episódios internacionais, épocas internacionais. 


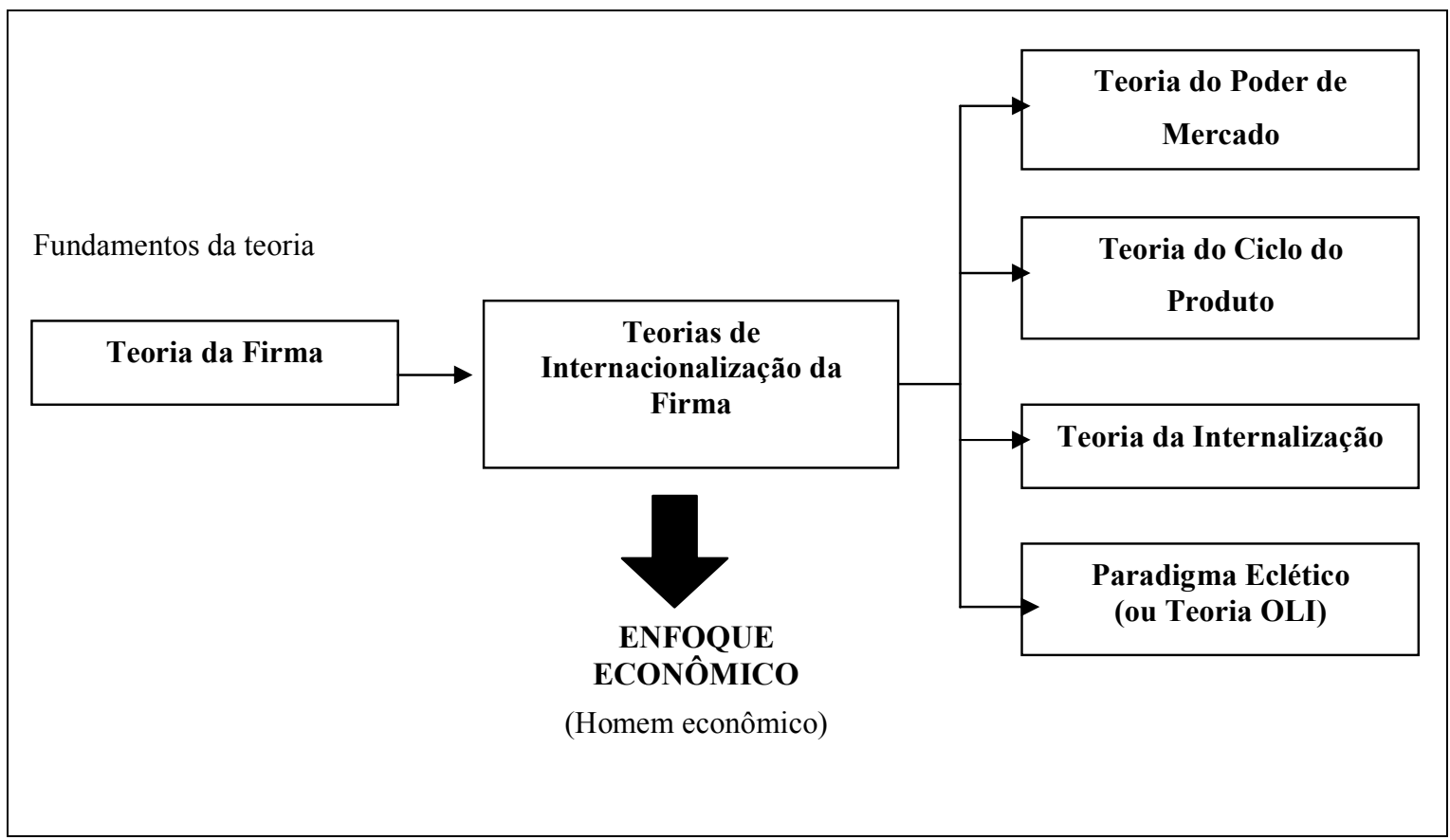

Ilustração 2 - Internacionalização da firma: enfoque econômico FONTE: HEMAIS e HILAL, 2004.

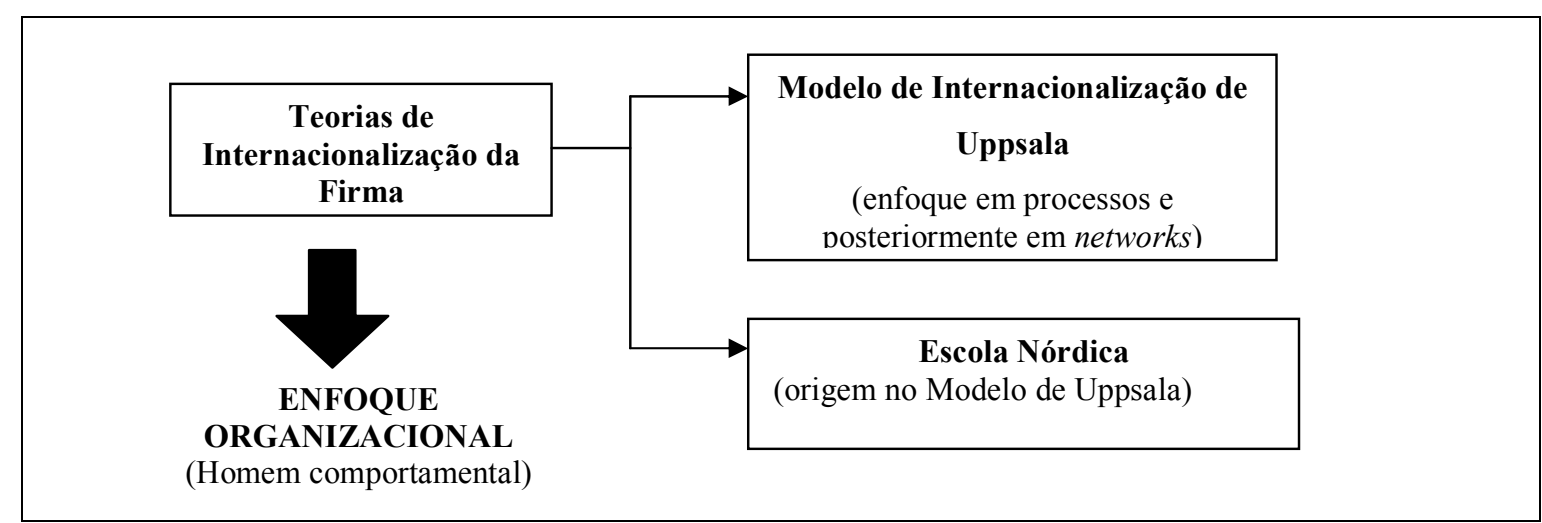

Ilustração 3 - Internacionalização da firma: enfoque organizacional FONTE: HEMAIS e HILAL, 2004.

De acordo com esses autores, a evolução internacional corresponde ao Modelo de Uppsala da Escola Escandinava e se relaciona a pequenas variações no envolvimento internacional de uma empresa, que ocorrem quase permanentemente em unidades diferentes da empresa e de maneira incremental. Episódios internacionais são processos que acontecem em departamentos ou divisões, algumas vezes até mesmo na empresa inteira, e se relacionam com mudanças decisivas no nível de internacionalização. Os episódios podem ser vistos como saltos - mudanças abruptas que alteram significativamente a configuração de uma divisão, de um trabalho ou de toda a empresa -, razão por que essas transformações podem ser 
consideradas marcos no desenvolvimento internacional das firmas (KUTSCHKER, BÄURLE, 1997). Épocas internacionais (epochs), por sua vez, são períodos mais longos no desenvolvimento da empresa, modelados por uma estratégia particular para a internacionalização. As épocas se caracterizam por um padrão e uma idéia específica, que dominam as atividades de internacionalização por certo período. As mudanças não são determinadas apenas pelo ambiente da firma, mas pela combinação das circunstâncias externas e a interpretação que fazem delas aqueles que estão na condução da empresa (ECKERT, MAYRHOFER, 2005).

Para Fleury e Fleury (2006), há em princípio três abordagens sobre a internacionalização nos modelos de gestão das empresas:

a) perspectiva de racionalidade econômica, buscando o entendimento dos fatores motivacionais sob a ótica econômica e das vantagens competitivas associadas, com fundamento no Paradigma Eclético de Dunning;

b) aspectos comportamentais e culturais como determinantes do processo, originada na Escola de Uppsala e Escola Nórdica;

c) questões de estratégia e estrutura ou arquitetura organizacional, baseada nas propostas de Porter.

Segundo Guedes (2007), as teorias podem ser agrupadas em Abordagens Econômicas, Abordagens Comportamentais, Abordagens Culturais, Abordagens Gerenciais e Abordagens de Barganha (esta última com base teórica das ciências políticas):

a) Abordagens Econômicas: Teoria da Internalização, Teoria dos Custos de Transação, Paradigma Eclético;

b) Abordagem Comportamental: Escola de Uppsala;

c) Abordagem Cultural: Gestão Intercultural;

d) Abordagens Gerenciais: Teoria Macro-Organizacional, Teoria Organizacional, Teoria Contingencial;

e) Abordagem de Barganha: Teoria da Barganha.

As teorias e abordagens sobre internacionalização de empresas são apresentadas segundo os enfoques econômico e organizacional propostos por Hilal e Hemais (2004) e organizadas nas Ilustrações 2 e 3. Guedes (2007) amplia a estrutura teórica e apresenta o enfoque gerencial e o enfoque cultural, que estão sistematizados nas Ilustrações 4 e 5. 


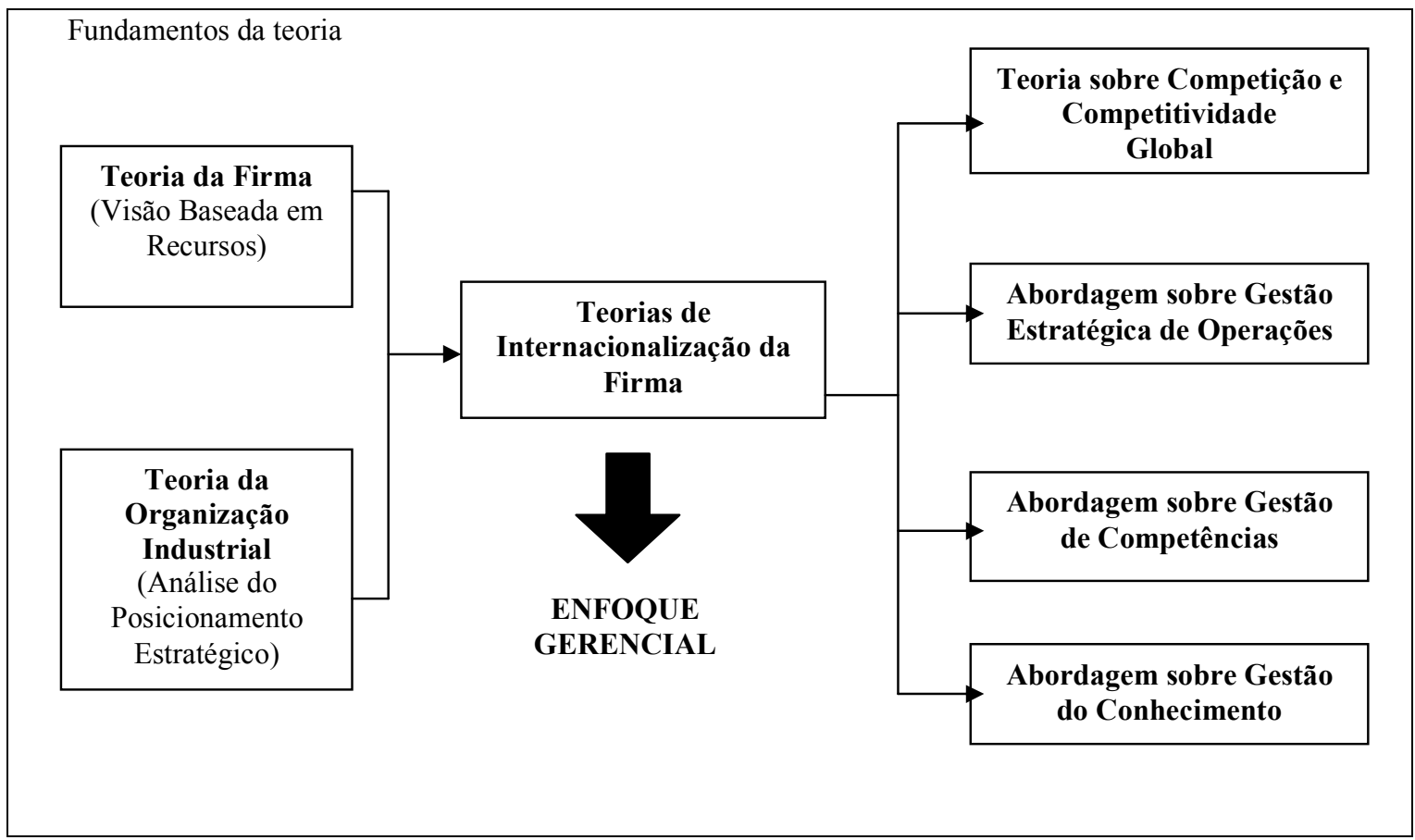

Ilustração 4 - Internacionalização da firma: enfoque gerencial FONTE: GUEDES, 2007.

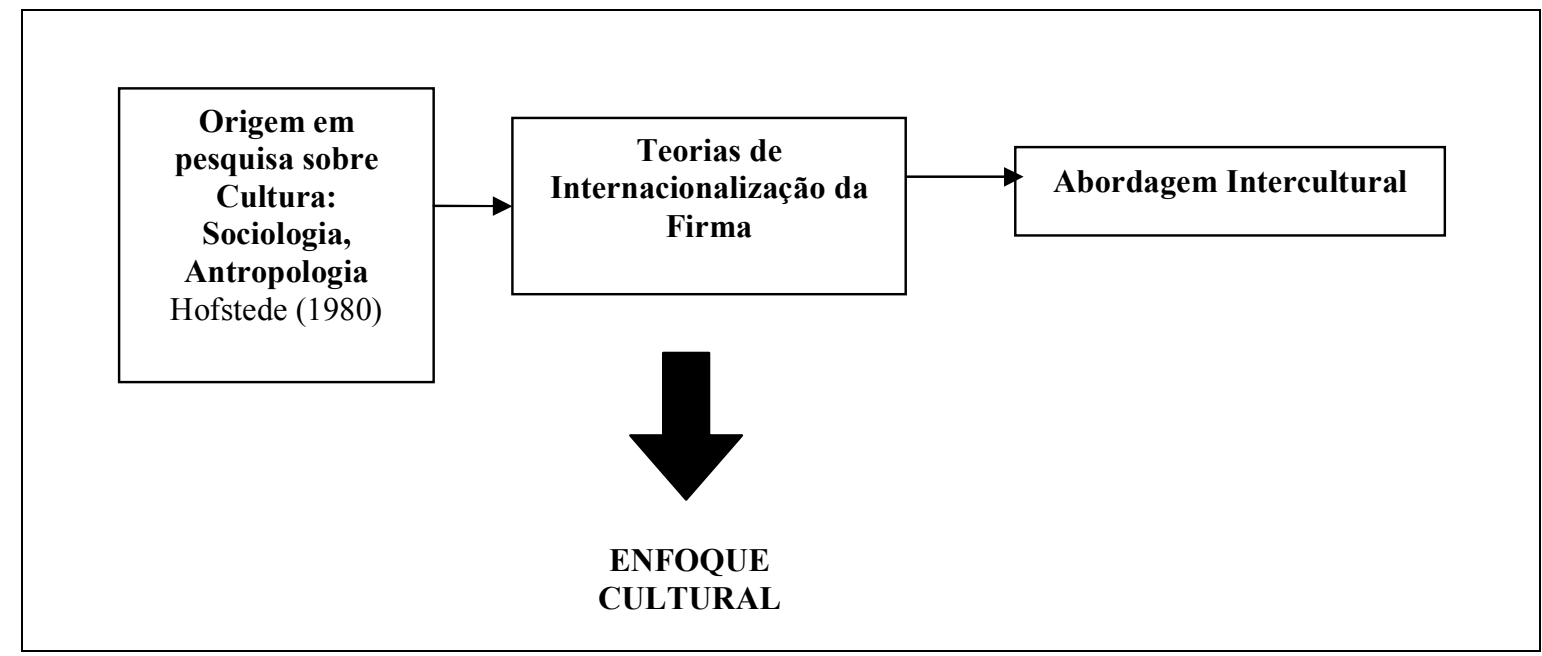

Ilustração 5 - Internacionalização da firma: enfoque cultural FONTE: GUEDES, 2007.

A análise das estruturas para organização das teorias desenvolvidas pelos autores relacionados neste estudo possibilita a proposição de uma taxonomia, utilizando como base a organização feita por Hilal e Hemais (2004) e por Guedes (2007). A proposta de uma Taxonomia de Encadeamento Teórico tem a finalidade de esclarecer e destacar as origens e as relações conceituais entre os fundamentos de cada teoria, abordagem e enfoque sobre 
internacionalização de empresas e as questões fundamentais inerentes ao processo de internacionalização. Além de propiciar uma visão da pluralidade conceitual existente para o tema da internacionalização de empresas, destaca a importância de associar os fatores existentes no ambiente onde a empresa está inserida e o fator tempo para uma compreensão mais acurada e ampla do processo de internacionalização de empresas. A finalidade desta análise é descortinar a relação que existe entre as diferentes abordagens conceituais para o processo de internacionalização: por que as empresas saem; para onde vão (por que as empresas escolhem determinado local); como entram e como se adaptam ao local. Uma Taxonomia de Encadeamento Teórico é, portanto, proposta para as teorias relacionadas à internacionalização de empresas, associando-se a essa taxonomia os fatores de risco abordados por Loureiro (1990): políticos, econômicos (incluindo cambiais), sociais, culturais, regulatórios (legislativos e jurídicos), ambientais, comerciais (competitivos e estratégicos) e financeiros. A análise conjunta dos fatores intervenientes confere uma maior aproximação com a realidade empresarial. Por fim, acrescentem-se, de um lado, as quatro dimensões sugeridas por Kutschker e Bäurle (1997) para avaliar o panorama sob a ótica do tempo quantidade e distância geográfico-cultural de cada país, valor adicionado (value added), integração e tempo - e, de outro, a estrutura de Eckert e Mayrhofer (2005), composta por três categorias para dividir o processo de internacionalização de cada empresa: evolução internacional, episódios internacionais e épocas internacionais.

A taxonomia chama a atenção para o processo de decisão de internacionalização da empresa, destacando que pode ser tomada por um indivíduo ou um grupo de pessoas. Em segundo lugar, identifica as teorias seminais, que são as bases conceituais para o processo de internacionalização das empresas: Teoria da Firma, Teoria da Organização Industrial, Sociologia e Antropologia. A Teoria da Firma constitui a base para a Teoria dos Custos de Transação e para a Visão Baseada em Recursos. A Teoria da Organização Industrial, por sua vez, é a base para a Análise do Posicionamento Estratégico. A Sociologia e a Antropologia formam a base da Abordagem Intercultural. Como conseqüência desse fato, cada teoria, abordagem e enfoque abrange um espectro diferente de questões relativas ao processo de internacionalização, e a taxonomia registra essas distinções. A Teoria do Poder de Mercado e as Teorias sobre Competição e Competitividade Global abordam todo o processo de internacionalização de empresas, desde por que sair até como se adaptar no novo local. A Teoria do Ciclo do Produto, a Teoria da Internalização, o Paradigma Eclético e a Escola Nórdica de Negócios Internacionais focalizam a parte do processo de internacionalização de 
empresas compreendida desde por que sair até como entrar no novo local. Entretanto, não olham para as questões relacionadas a como a empresa se adapta a esse local. A Escola de Uppsala aborda as questões relacionadas à internacionalização de empresas inerentes a para onde se deslocar e como entrar no novo local. A Abordagem sobre Gestão Estratégica de Operações não focaliza o porquê de uma empresa sair para novos locais, e sim o processo a partir dessa decisão já tomada, abrangendo as questões de para onde ir, como entrar e como se adaptar ao novo local. E, por fim, a Abordagem sobre Gestão de Competências, Abordagem sobre Gestão do Conhecimento e Abordagem Intercultural se concentram nas questões relativas a como entrar no novo local e como se adaptar a ele.

A taxonomia indica também que o processo de internacionalização das empresas é composto por quatro questões fundamentais: por que as empresas saem (domesticamente e/ou internacionalmente), para onde vão (por que as empresas optam por um determinado lugar), como é que entram (modos de entrada) e como se adaptam à nova localização. Essa taxonomia pode ser empregada para os casos de deslocamento interno (no país de origem) ou para processos internacionais (Ilustração 6).

\subsection{Conceituação das teorias de internacionalização com base no enfoque econômico}

\subsubsection{Teoria do Poder de Mercado}

A Teoria do Poder de Mercado, inspirada na Teoria da Firma e na Teoria da Organização Industrial (Ilustração 7) e cujas bases foram lançadas por Hymer em sua tese de doutorado, em 1960, está registrada em seu livro de 1976 (1976; HEMAIS, HILAL, 2004): a firma é o agente para o poder de mercado e de conluio. 


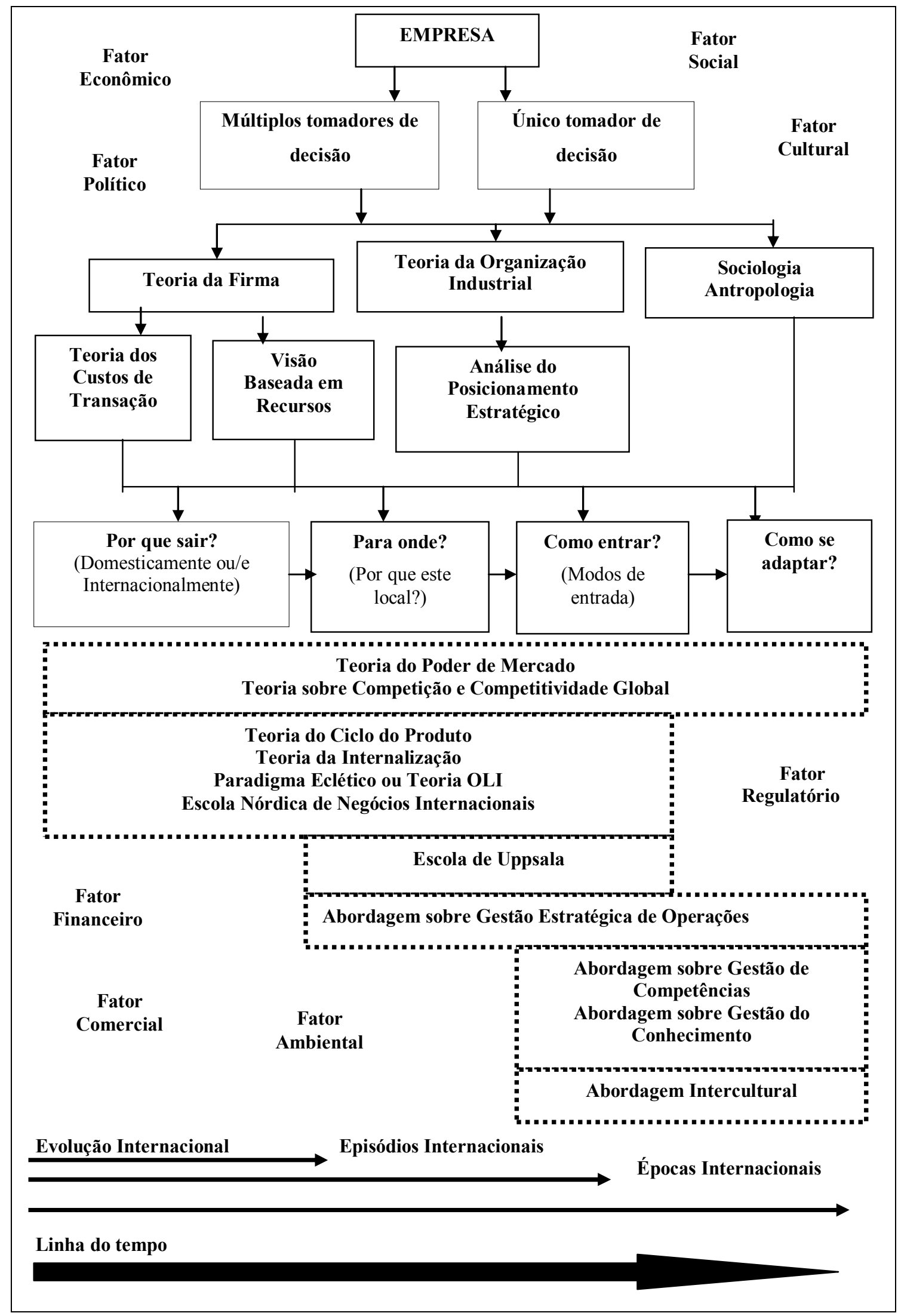

Ilustração 6 - Taxonomia de Encadeamento Teórico 
O autor destaca três razões principais para uma empresa controlar outras organizações em países estrangeiros. Uma delas é a remoção da competição por meio de conluios ou fusões; outra razão é o uso de uma vantagem única da empresa (facilidade de acesso aos fatores de produção, controle de formas de produção mais eficientes, melhor sistema de distribuição ou posse de um produto diferenciado); a terceira razão que leva a firma a produzir no exterior são as imperfeições de mercado. A principal motivação para o investimento direto não são as taxas de juros mais altas, e sim os lucros que derivam do controle do empreendimento no estrangeiro. Há uma tendência para que o investimento ocorra regularmente em um mesmo grupo de indústrias, o que vale para diferentes partes do mundo (HYMER, 1970, 1976; HEMAIS, HILAL, 2004).

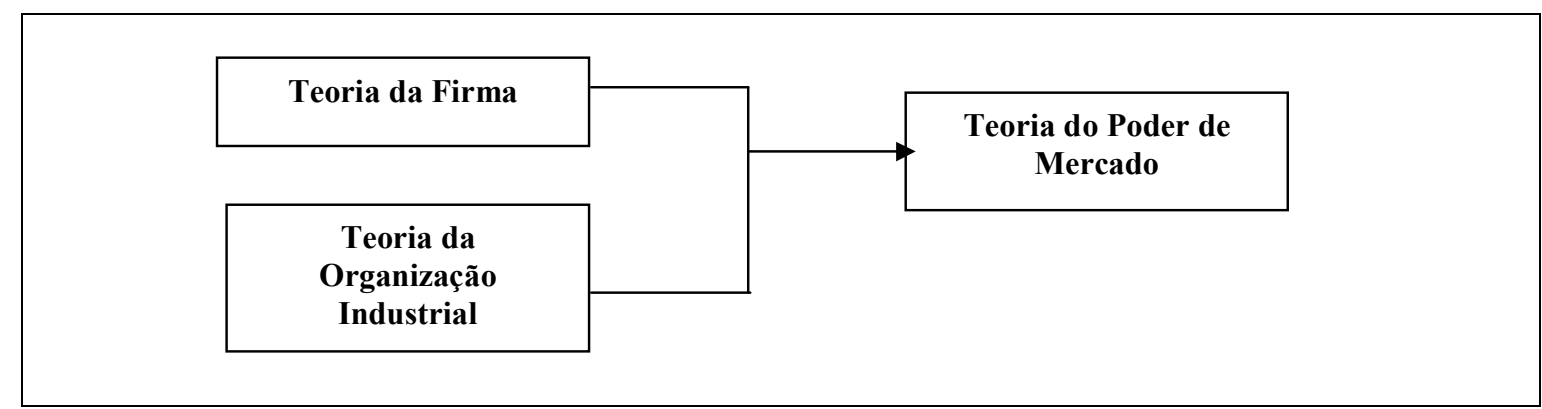

\section{Ilustração 7 - Fundamentos da Teoria do Poder de Mercado} FONTE: HEMAIS e HILAL, 2004.

Como há imperfeições no mercado, é mais vantajoso coordenar as atividades de produção dentro da firma do que mediá-las nos mercados. Dessa maneira, as firmas podem internalizar o mercado por meio de investimentos diretos no exterior ou externalizar os mercados via licenciamento. Quando opta pelo investimento direto, ou seja, a venda de suas vantagens para outras empresas que possuam poderes monopolísticos nos seus mercados, a firma evita a complexidade de conseguir acordos entre licenciador e licenciado, incluindo-se a supervisão de preços e do output, ou a perda de lucratividade e da vantagem competitiva (HEMAIS, HILAL, 2004).

A internalização acontece principalmente em situações de monopólio ou oligopólio de mercado. O controle é fundamental para reduzir ou remover a competição e para que haja a apropriação completa dos resultados do emprego de um ativo específico. Para os casos de mercados com competição perfeita, ou seja, a existência de muitas firmas, o mais provável será o licenciamento. Muitas empresas iniciam suas operações por intermédio do licenciamento e depois acabam adquirindo alguma participação ou até o controle total do 
licenciado (HEMAIS, HILAL, 2004). Contudo, Hymer (1983) destaca o fato de que não há um modo predefinido para essas tomadas de decisão, já que os mercados são bastante imperfeitos, o que leva a um desenvolvimento desigual das empresas.

Horaguchi e Toyne (1990) abordam o conceito de recursos gerenciais (managerial resources), que pode ser definido como administrativo, tecnológico, marketing, conhecimento organizacional e habilidades necessárias aos trabalhadores para conduzir a empresa de modo eficiente. Esses recursos estão associados basicamente ao intelecto humano e, por essa razão, podem ser transferidos dentro da firma sem custos adicionais. Apesar de os limites da firma e do mercado poderem ser explicados pelo conceito dos custos de transação em uma condição de estabilidade externa, a criação de um novo mercado não pode ser explicada pela minimização dos custos de transação. A heterogeneidade e assimetria da distribuição dos recursos gerenciais ao longo da firma evoluem com o tempo e criam vantagens únicas para cada organização. Como a empresa é uma combinação de recursos gerenciais, ela pode criar novos mercados. Acrescente-se o fato de que recursos gerenciais são acumulados durante o processo de inovação e adaptação ao novo mercado que também contribuirá para a construção da vantagem. Ou seja, a firma não é apenas reativa, reduzindo custos por meio da internalização de mercados, mas proativa, quando cria produtos, mercados, organizações, técnicas e tecnologias. O resultado dessa proatividade é que a firma aprimora suas linhas de produtos e o domínio geográfico de suas atividades.

As formas adotadas nas operações internacionais estão relacionadas também à legislação e regulamentação dos governos dos locais onde se estabelecem as subsidiárias, bem como dos fluxos de capital, tecnologia, mão-de-obra qualificada, os custos de se internacionalizar (adquirir informação como economia, língua, legislação, política etc.), os riscos (como a flutuação de taxas de câmbio) e as barreiras tarifárias ou não-tarifárias existentes na ocasião.

As teorias sobre internalização e o poder de mercado não são mutuamente excludentes, mas complementares, dedicando-se a esclarecer de forma mais completa o crescimento de multinacionais (BUCKLEY, 1990; HEMAIS, HILAL, 2004). 


\subsubsection{Teoria da Firma - Teoria dos Custos de Transação}

Coase (1937) afirma, em The Nature of the Firm, que existem custos associados ao funcionamento dos mercados. O autor critica a visão da firma como uma função de produção, pois para ele a firma é uma relação orgânica entre agentes, que se efetiva por meio de contratos, sejam explícitos, como os de trabalho, ou implícitos, como parcerias formais: "Coase mostra que são os custos de transação um dos mais importantes fatores que moldam as relações econômicas na sociedade contemporânea.” (SAES, 2007, p. 20).

Cada transação envolve direito de propriedade. Os custos de transação são custos de trocar, capturar e proteger direitos de propriedade e resultam da elaboração e negociação dos contratos, da mensuração e fiscalização de direitos de propriedade, do monitoramento do desempenho, da organização das atividades, da adaptação às mudanças no sistema econômico, do monitoramento das transações e do desempenho dos agentes envolvidos (SAES, 2007).

\footnotetext{
Quando custos de transação são introduzidos (isto é, há falhas de mercado) os direitos de propriedade não são perfeitamente protegidos. A sua proteção torna-se uma atividade custosa. Recursos serão gastos para apropriar direitos de propriedades. Portanto, valores são dissipados. Ambos, gerentes e estratégia passam a ter um papel a desempenhar: criar valor ao desenhar estruturas de governança que visem reduzir custos de transação. (SAES, 2007, p. 21).
}

A fim de compreender a Teoria dos Custos de Transação, deve-se levar em conta que a empresa, ao se instalar em um mercado, incorrerá em custos. São os chamados custos de transação. No caso de a empresa decidir entrar no mercado estrangeiro por meio da exportação, enfrentará os custos relacionados à busca de informação e ao cumprimento de contratos. Já no caso de a empresa decidir entrar no mercado de forma mais comprometida, como por meio de aliança estratégica, subsidiária ou aquisição de outra empresa, incorrerá nos custos de obtenção de conhecimento do mercado, instalação da empresa no exterior, controle e coordenação das atividades, entre outros. São os chamados custos de internalização (BORINI, COELHO, RIBEIRO, PROENÇA, 2004).

\subsubsection{Teoria da Organização Industrial}

Bain (1959) é o principal autor da Teoria da Organização Industrial (OI), que examina os padrões existentes nas estruturas de mercado, as formas de conduta de mercado entre vendedores e compradores e o desempenho do mercado na economia americana. Esse modelo 
de análise de mercado denomina-se Estrutura, Conduta e Desempenho (Structure, Conduct, Performance) ou ECD. O autor demonstra que há associação entre a estrutura (structure), a conduta (conduct) e o desempenho (performance) de uma indústria e que essa relação pode explicar o desempenho do mercado e até indicar o que irá acontecer.

O desempenho de um negócio é variado e complexo, pois reflete diversas funções e interrelações com o resto da economia. De modo geral, podem-se reconhecer três fases. A primeira relaciona-se ao desempenho da empresa como compradora no mercado de fatores básicos de produção - mão-de-obra e recursos naturais. A segunda fase é o desempenho interno da empresa: como ela organiza os recursos de produção, como gerencia sua utilização e o emprego dos materiais e trabalhadores, como escolhe as técnicas e os métodos de produção e gerenciamento financeiro. A terceira fase compreende o desempenho da empresa em relação ao mercado de bens e serviços, ou seja, como determina os produtos, preços, desenho dos produtos e custos de venda. Trata-se do desempenho como resultado dos ajustes necessários no interior da empresa e condicionados pela demanda e oferta no mercado onde atua. A relação entre os diversos determinantes e a empresa define seu desempenho. Como cada empresa atua de maneira distinta em função desses determinantes, também acaba por apresentar um desempenho distinto. Os determinantes do desempenho do mercado são a organização ou estrutura de um grupo ou indústria (mesmo que composta por empresas concorrentes) e a conduta de mercado (BAIN, 1959).

A firma é vista, primeiramente, a partir de seus condicionantes externos, tanto de oferta (principalmente tecnologia) como de demanda (elasticidade-preço), que determinam a estrutura de mercado na qual a firma se insere. A estrutura que compreende as características da organização do mercado (número de firmas, tamanho absoluto e relativo e barreiras à entrada), por sua vez, condiciona a conduta ou as práticas competitivas da firma, notadamente as estratégias de determinação de preço, de produção e propaganda, além de gastos em pesquisa e desenvolvimento (P\&D) e planos de investimento. Tais práticas competitivas resultam no desempenho da firma (BAIN, 1959; SAES, 2007).

\subsubsection{Teoria do Ciclo do Produto}

A Teoria do Ciclo do Produto (Ilustração 8) baseia-se nos trabalhos de Hirsch - que em sua tese de doutorado $(1965,1976$; HEMAIS, HILAL, 2004) destaca as primeiras características 
do ciclo dos produtos - e Vernon $(1966,1979,1980)$, que trata de comércio internacional e investimentos.

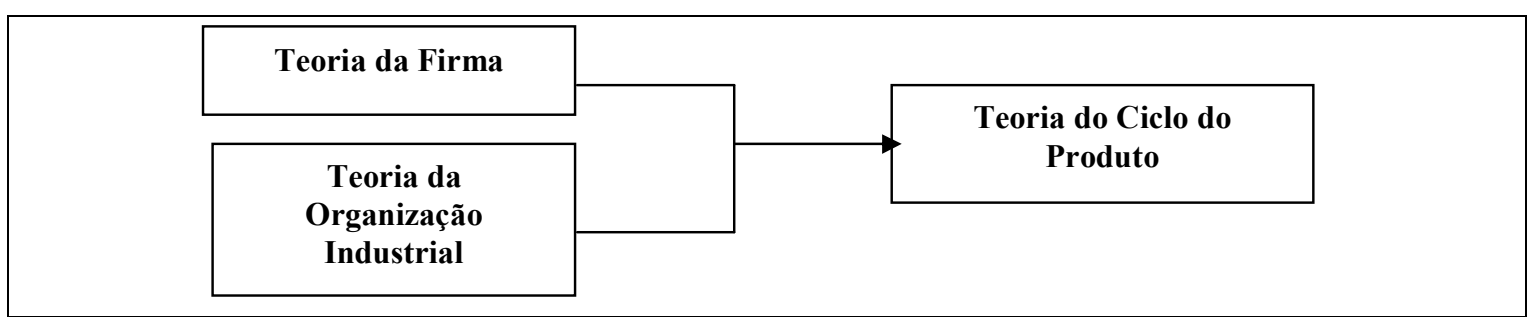

Ilustração 8 - Fundamentos da Teoria do Ciclo do Produto FONTE: HEMAIS e HILAL, 2004.

Hirsch (1965) aborda a questão do ciclo do produto em relação à competitividade internacional na experiência da indústria eletrônica americana da época. Observa que os produtos atravessam fases em seu ciclo de vida, que vão desde a invenção até a maturidade, e que as taxas de crescimento da demanda variam. No início, o crescimento é lento; acelera-se com o tempo e depois cai novamente, quando o produto atinge a maturidade. Essas fases são acompanhadas por mudanças na importância dos fatores de produção como a necessidade de mão-de-obra capacitada, capital e habilidades gerenciais. Essas mudanças têm implicações na competitividade internacional. A Teoria do Ciclo do Produto sugere que a competitividade internacional em qualquer indústria não é constante ao longo do tempo. Um país com uma situação de grande competitividade pode perder posição quando uma indústria se desloca de uma para outra fase de seu ciclo de produto. Sabendo que o potencial competitivo é dinâmico, os fabricantes de países desenvolvidos podem antecipar o declínio de sua competitividade quando seus produtos estão para atingir a fase de maturidade.

O objetivo de Vernon $(1966,1979)$ é explicar como investimentos diretos se dão em países estrangeiros e como se modifica o padrão de exportação, importação e produção no exterior em função do ciclo de vida de um produto. Segundo essa teoria, as inovações são resultado de demandas do mercado doméstico. Os produtos (ou a tecnologia) passam por três fases durante seu ciclo de vida: introdução, crescimento e maturação. Em cada fase há uma estratégia distinta na firma. A fase de introdução é geralmente vivenciada por países mais desenvolvidos, onde se verifica uma mudança constante nas tecnologias, evolução do mercado e grandes investimentos destinados à pesquisa e ao desenvolvimento. A fase de crescimento é geralmente marcada pela demanda estrangeira: quando a tecnologia começa a ser difundida, a produção se dá em larga escala (produção em massa), as barreiras de entrada são atenuadas e a produção se espalha por outros países desenvolvidos. A fase de maturação é 
marcada por produção e tecnologia mais padronizadas e sem inovações, além da necessidade de mão-de-obra pouco qualificada. Nesse momento o foco é a redução dos custos e por essa razão a produção é transferida para países que tenham custos mais baixos, como os países em desenvolvimento, que se tornam apenas bases de produção (HIRSCH, 1965; VERNON, 1966, 1979). O produto final acaba sendo exportado para o país de origem da firma a um preço inferior ao que teria caso fosse produzido nesse local. Contudo, o próprio Vernon (1980) destaca a insuficiência de sua teoria em função da evolução do ambiente internacional. No novo panorama se verifica a transferência da produção para outros países mesmo nos primeiros anos, ou seja, muito antes da fase de maturação do produto (HEMAIS, HILAL, 2004; BORINI, COELHO, RIBEIRO, PROENÇA, 2004).

\subsubsection{Teoria de Internalização}

Buckley (1990) e Buckley e Casson (2002) desenvolveram a Teoria de Internalização (The Internalisation Approach) para explicar o crescimento da firma (Ilustração 9). Essa abordagem tem como base a Teoria da Firma, de Coase. Segundo a Teoria de Internalização, a escolha dos locais obedece ao critério de oferta de custos menores para as atividades e implica internalização do mercado até os custos das trocas se igualarem. Há tendência de internalização quando o volume de trocas entre firmas é intenso (HEMAIS, HILAL, 2004).

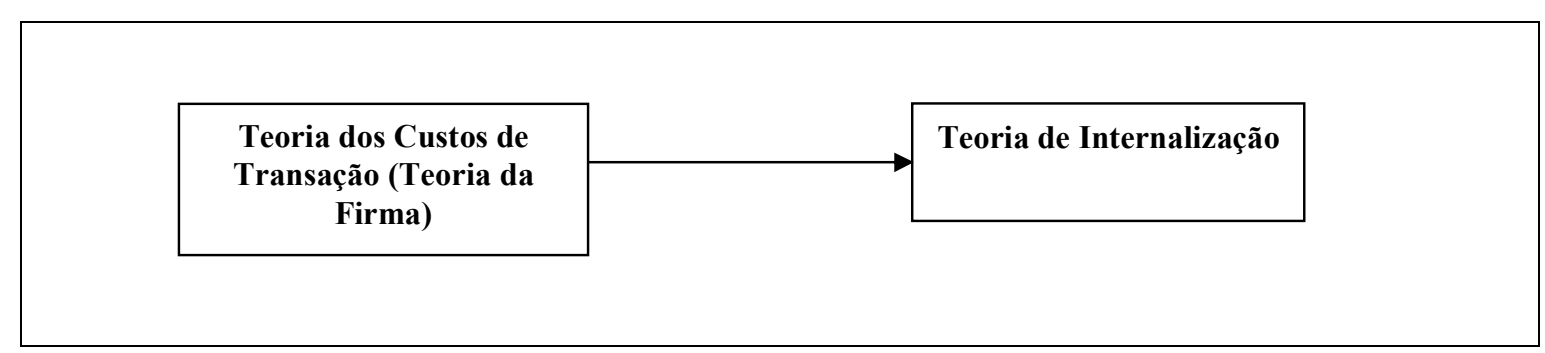

\section{Ilustração 9 - Fundamentos da Teoria de Internalização} FONTE: HEMAIS e HILAL, 2004.

Segundo Coase (1937), a produção acontece por coordenação, por trocas de mercado ou dentro da firma. Nesse sentido, os custos de transação são os delineadores dos contornos da firma. Entende-se por transações desde os produtos até a tecnologia, passando pelas formas de gestão e, principalmente, o conhecimento. Quanto mais transações baseadas em conhecimento, maior a propensão para a internalização; logo, maior a probabilidade de a empresa adotar formas de atuação mais complexas no exterior, distanciando-se da simples exportação. A firma internalizará a produção quando os custos de produção no mercado e a 
especificidade dos ativos forem grandes. A externalização da produção acontece na medida em que os custos das transações no mercado sejam inferiores aos de produção dentro da firma ou quando os ativos exigidos tendam a ser pouco específicos, ou, ainda, para vencer barreiras de entrada e incertezas de mercado (HEMAIS, HILAL, 2004).

A firma iniciará seu crescimento por exportação, alterará para licenciamento à medida que o mercado começar a crescer e adotará o investimento direto ao final do processo. Entretanto, esse padrão de evolução não é único. As formas adotadas para expansão da firma estão relacionadas, assim, à estrutura de custos e ao padrão de crescimento do mercado. Diversos autores chamam a atenção para o fato de que o único padrão fixo é que, em um mercado em expansão, nunca uma forma de atuação quebrará a seqüência de estabelecer em primeiro lugar a exportação, depois o licenciamento e, ao final, o investimento direto (BUCKLEY, 1990; BUCKLEY, CASSON, 2002; BORINI, COELHO, RIBEIRO, PROENÇA, 2004; HEMAIS, HILAL, 2004; PAULA, PROENÇA, 2005).

\subsubsection{Paradigma Eclético}

Para Dunning (1988), o Paradigma Eclético (Ilustração 10) não é uma teoria, mas um arcabouço para analisar a produção internacional. Sua intenção é delinear uma explicação ampla para a teoria de produção internacional da firma com base em vários ramos da teoria econômica (HEMAIS, HILAL, 2004).

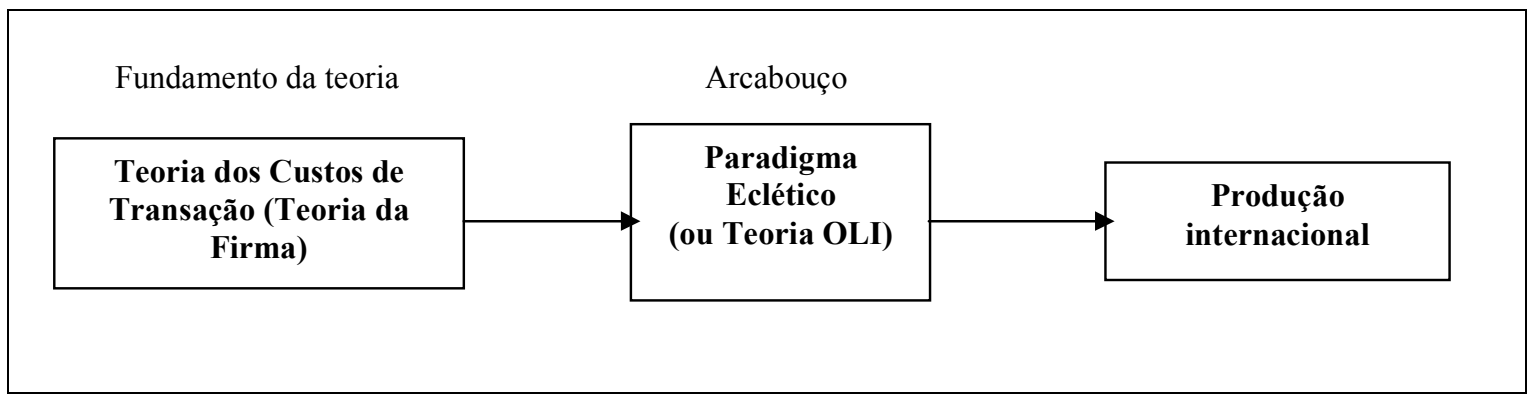

Ilustração 10 - Fundamentos do Arcabouço do Paradigma Eclético FONTE: HEMAIS e HILAL, 2004.

O Paradigma Eclético (ou Teoria OLI) determina que a firma, ao decidir iniciar uma produção internacional, precisa ter alguma vantagem sobre seus concorrentes. Quando isso acontece, a firma internaliza a produção. A internacionalização acontecerá apenas se houver interesse econômico em localizar a produção em mercados estrangeiros, de modo a capturar os 
benefícios econômicos existentes nesses mercados. O Paradigma Eclético compõe-se de três pilares. O primeiro é a vantagem específica de propriedade $(O$ - ownership-specific advantage). A vantagem de propriedade inclui os aspectos relacionados aos ativos tangíveis e intangíveis - como marcas, capacitação tecnológica e qualificação da mão-de-obra. A empresa, ao atuar no estrangeiro, pode e deve aproveitar suas competências como um diferencial para disputar com os novos concorrentes. Essas competências essenciais seriam, sobretudo, desenvolvidas na matriz e transmitidas para as subsidiárias. O segundo pilar é a vantagem específica de localização ( $L$ - location-specific variables). As vantagens de localização são aquelas oferecidas pelos países - como recursos naturais, mão-de-obra, infraestrutura e tamanho do mercado. É um caso de vantagem de localização a busca por matériasprimas e mão-de-obra mais baratas do que no país de origem, o que viabiliza a produção destinada a outros mercados a custos mais competitivos em nível internacional. E o último pilar é a vantagem de internalização ( $I$ - internalization), que se refere à capacidade e ao desejo das empresas multinacionais de transferir ativos através das fronteiras nacionais dentro da própria hierarquia, ao invés de se valer do mercado internacional. Essa vantagem apóia-se na Teoria de Internalização e na Teoria dos Custos de Transação. Assim, as vantagens de internalização advêm da diminuição dos custos de câmbio, da propriedade da informação e redução da incerteza, do maior controle da oferta e dos mercados e, sobretudo, da maior possibilidade de acordos contratuais e de negócios (DUNNING, 1988; BORINI, COELHO, RIBEIRO, PROENÇA, 2004; HEMAIS, HILAL，2004; PAULA， PROENÇA， 2005; RODRIGUES, MADEIRA, THEUER, MEDINA, FLEURY, 2006).

Há duas categorias de vantagens competitivas que podem criar uma posição monopolística para as multinacionais: as vantagens relacionadas à especificidade do ativo e as relativas ao direito de propriedade de ativos complementares. A produção internacional é classificada como uma atividade de adição de valor que a firma organiza para além dos seus limites domésticos (HEMAIS, HILAL, 2004).

As três vantagens apontadas por Dunning são necessárias para explicar a forma, o padrão e a extensão do processo de internacionalização da empresa. As vantagens de propriedade, também chamadas vantagens monopolísticas ou vantagens competitivas, seriam indispensáveis para a empresa superar os custos adicionais de entrar em um novo mercado e competir com concorrentes locais (DUNNING, 1988; PAULA, PROENÇA, 2005). 
O Paradigma Eclético procura explicar a extensão, o modo e o padrão da produção internacional e se fundamenta na justaposição das vantagens específicas e de propriedade das firmas, contemplando a produção estrangeira e a propensão à internalização dos mercados além-fronteira, bem como a atração de mercados estrangeiros para a produção. As decisões sobre a entrada em mercados internacionais são, conseqüentemente, tomadas de maneira racional, com base em análises dos custos de transação. Os custos de transação são particularmente úteis para explicar as decisões de integração vertical e o modo como as firmas, especialmente as multinacionais, avaliam se estabelecem ou não uma subsidiária de produção num mercado estrangeiro (DUNNING, 1988; WHITELOCK, 2002).

A abordagem dos Custos de Transação parte do pressuposto de que os mercados são competitivos e neles há muitos fornecedores (neste caso, trata-se de agentes e distribuidores). Nessas condições, as modalidades de baixo controle são favorecidas pela ameaça de substituição, que reduz o oportunismo e força os fornecedores a atuarem eficientemente. Quando a possibilidade de fornecedores para a firma é restrita, há pouca ameaça de substituição e os custos de transação associados às modalidades de baixo controle são aumentados pela necessidade de negociação estrita e de supervisão das relações contratuais. Os benefícios da integração (controle) devem ser comparados com os custos de integração (custos dos compromissos de recursos). A Teoria dos Custos de Transação prediz que firmas integram quando as especificidades dos ativos são grandes e para manter o controle sobre as vantagens específicas oferecidas no mercado. Em relação ao modo de entrada, o Paradigma Eclético sugere que as firmas fazem suas escolhas com base na avaliação dos custos de cada modo de entrada em relação a seus objetivos. Conseqüentemente, a Teoria dos Custos de Transação tende a investigar os modos de entrada ou produção dentro do mercado (WHITELOCK, 2002).

\subsection{Conceituação das teorias de internacionalização com base no enfoque organizacional}

\subsubsection{Escola de Uppsala}

$\mathrm{Na}$ década de 70, pesquisadores da Universidade de Uppsala (JOHANSON, WIEDERSHEIM-PAUL, 1975; JOHANSON, VAHLNE, 1977) focalizaram seu interesse no 
processo de internacionalização de firmas suecas manufatureiras e desenvolveram um modelo de como essas firmas escolhiam mercados e formas de entrada quando decidiam se internacionalizar. A pesquisa foi amplamente influenciada pelos trabalhos sobre a Teoria Comportamental da Firma (A Behavioral Theory of the Firm), de Cyert e March (primeira edição em 1963; segunda edição em 1992), e pela Teoria do Crescimento da Firma (Theory of the Growth of the Firm), de Penrose (1959).

A principal contribuição da Escola de Uppsala (Ilustração 11) é o fato de trazer para o centro do debate a perspectiva da Teoria do Comportamento Organizacional, além do enfoque econômico (HILAL, HEMAIS, 2003; HEMAIS, HILAL, 2004). O modelo de internacionalização criado baseia-se no desenvolvimento da firma individual, na aquisição gradual, na integração e no uso do conhecimento sobre operação e mercados estrangeiros como explicação para a existência de um comprometimento crescente nos mercados internacionais. Para Johanson e Vahlne (1977), a internacionalização acontece por meio de uma série de decisões incrementais. É um processo gradual. O modelo emprega uma primeira variável, a distância psíquica, para definir os padrões de internacionalização. Segundo esse conceito, as firmas se expandem primeiro para mercados psiquicamente próximos e depois para mercados mais distantes, à medida que desenvolvem conhecimento. De acordo com Hemais e Hilal (2004), a distância psíquica pode ser definida como a soma de fatores que não permitem ou que dificultam o fluxo de informação entre determinados mercados. As diferenças podem ser de cultura, idioma, educação, práticas de negócio e desenvolvimento industrial. Por essa razão, as firmas escolhem como mercados internacionais os países com menor distância psíquica em relação ao país da matriz. Segundo Johanson e Vahlne (1977), a internacionalização não acontece em função de adoção de uma estratégia para alocação ótima dos recursos. 


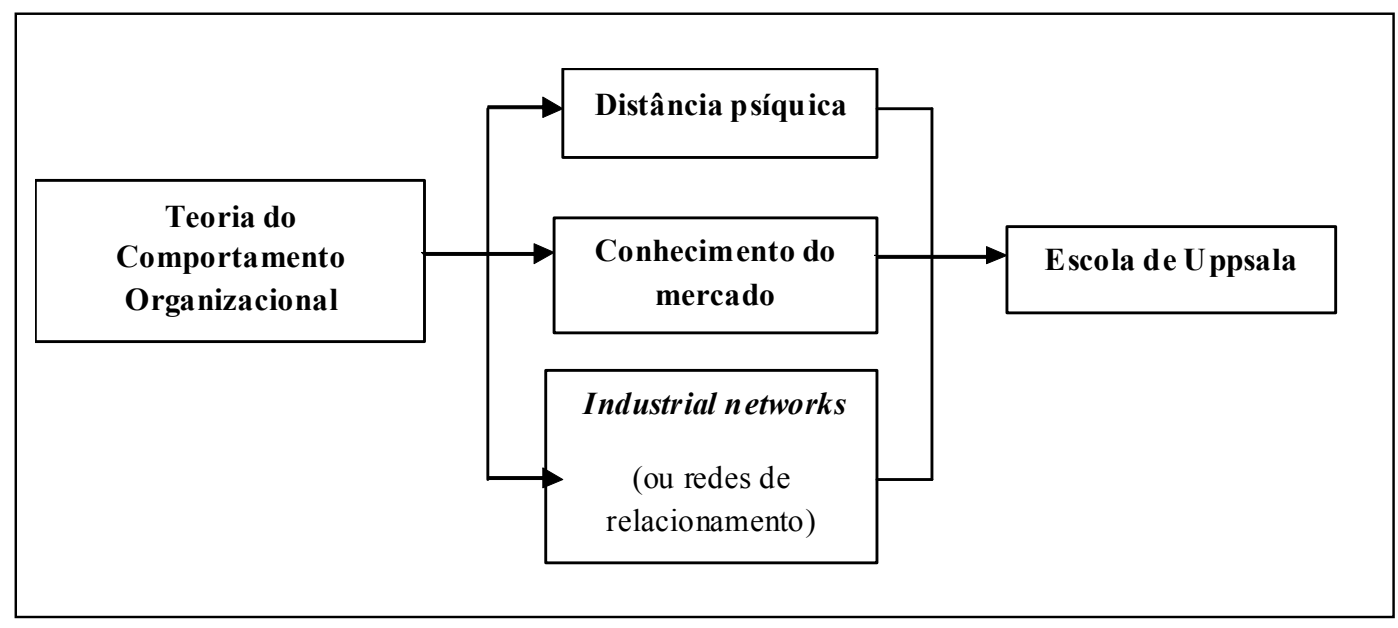

Ilustração 11 - Fundamentos da Escola de Uppsala FONTE: HEMAIS e HILAL, 2004.

A segunda variável justifica o gradualismo do processo de internacionalização: é a falta de conhecimento (ou a dificuldade de obtê-lo) sobre o mercado para o qual se pretende deslocar. Identificam-se dois tipos de conhecimento. O primeiro é chamado de conhecimento objetivo, ou seja, aquele que pode ser ensinado; o segundo é o conhecimento experimental, que se desenvolve por meio da vivência pessoal de cada indivíduo. O conhecimento experimental é avaliado como crítico no processo de internacionalização, já que é adquirido gradativamente, à medida que a empresa vai tendo experiências internacionais. $\mathrm{O}$ conhecimento de mercado é classificado em duas modalidades: geral e específico. $\mathrm{O}$ conhecimento geral refere-se a métodos de marketing, características comuns aos consumidores, que independem de localização. O conhecimento específico abarca as características de determinados mercados em particular, tais como padrões culturais, ambiente de negócios, estrutura de mercado, características específicas das firmas e dos consumidores (PENROSE, 1959; JOHANSON, VAHLNE, 1990; HILAL, HEMAIS, 2003; HEMAIS, HILAL, 2004).

A terceira variável é o relacionamento com outras entidades do mercado estrangeiro, ou a network industrial (industrial network). Nos mercados industriais as firmas estabelecem, desenvolvem e mantêm relacionamentos com outras entidades. Esses relacionamentos formam as redes ou networks. Fazem parte dessas redes os clientes, fornecedores, concorrentes, distribuidores, agentes e agências reguladoras. Os atores que compõem as redes estão ligados por questões técnicas, de maneira social, cognitiva, administrativa, legal, econômica. As relações são complexas e não podem ser completamente compreendidas pelos agentes que compõem uma determinada rede. Como resultado, o modelo demonstra que o 
processo de internacionalização acontece no interior da organização e entre organizações. Os relacionamentos que a firma estabelece em outros países podem ser classificados em três categorias: relacionamentos em novos países que constituem uma extensão internacional; desenvolvimento do relacionamento dentro dessa rede, ou penetração; e conexão entre as redes de diferentes países, ou integração internacional (JOHANSON, VAHLNE, 1990; WHITELOCK, 2002; HEMAIS, HILAL, 2004).

Um dos pressupostos da escola é que a internacionalização da firma, seja por meio de exportações, seja por meio de investimentos diretos, é uma decorrência do seu crescimento. Quando o mercado doméstico está saturado e, conseqüentemente, o número de oportunidades lucrativas diminui até o ponto de impedir a ampliação da firma, devem-se buscar novos locais para se expandir. Dado que as novas alternativas geralmente parecem ser mais incertas do que as velhas fórmulas familiares, supõe-se que a expansão seja dirigida para locais o mais possível similares àqueles das operações existentes. Se a expansão vertical é descartada por ser muito incerta ou não-lucrativa, o caminho a seguir é, normalmente, a expansão geográfica. Portanto, dentro dessa perspectiva, o processo de internacionalização não é visto como uma seqüência de passos planejados e deliberados com base em uma análise racional, mas como uma seqüência de passos de natureza incremental, visando a se beneficiar da aprendizagem sucessiva por meio de etapas de comprometimento crescente com os mercados estrangeiros (HILAL, HEMAIS, 2003).

Johanson e Vahlne (1990) sugerem que há três exceções para o modelo de entrada: quando as firmas possuem amplos recursos, espera-se que dêem grandes passos ao se internacionalizarem; quando as condições de mercado são estáveis e homogêneas, conhecimentos relevantes podem ser adquiridos de outras maneiras que não por meio de experiência; quando a firma tem considerável experiência em mercados que apresentam condições similares, pode-se generalizar essa experiência para um outro mercado específico.

Blomstermo e Sharma (2003) destacam a existência de um número significativo e crescente de firmas que iniciam suas operações internacionais muito cedo em seu ciclo de vida, reforçando a posição de que nem todas as firmas obedecem a uma seqüência de expansão incremental e gradual. 
Segundo Hilal e Hemais (2003), os pesquisadores de Uppsala nunca afirmaram que a teoria evolucionista explica todas as expansões de cada firma ou as seqüências de entrada em um mesmo mercado, uma vez que características específicas das empresas, das indústrias e dos fatores de localização também exerciam forte influência sobre o fenômeno. $O$ processo evolucionário defendido pela escola, porém, parecia ser o mais típico entre as empresas.

\subsubsection{Distância psíquica}

De acordo com Nordström e Vahlne (1994), o conceito de distância psíquica coloca seu foco na firma como unidade de análise. Esse conceito tem por finalidade explicar as razões que levam uma empresa a se internacionalizar de determinada maneira, e se constitui dos fatores que podem impedir ou dificultar o aprendizado das empresas ou seu entendimento de um ambiente estrangeiro. Nesse sentido, a empresa precisa aprender não apenas sobre as leis e o sistema de distribuição de um país, mas também sobre sua cultura, para ser capaz de se relacionar com os fornecedores, consumidores e outros agentes naquele meio, a fim de fazer em si mesma os ajustes necessários para conseguir atuar no novo local.

A Escola de Uppsala definiu o construto distância psíquica como a soma dos fatores que interferem no fluxo de informação entre países. Dentro de uma visão mais ampla, a Escola Nórdica advoga a noção de que a distância psíquica está relacionada à percepção e, como tal, é uma noção subjetiva, englobando níveis variados de ansiedade e incerteza. $\mathrm{Na}$ visão da Escola de Uppsala, o construto distância psíquica leva as firmas a selecionarem os mercados de entrada em ordem crescente da distância percebida, o que pode ou não coincidir com a distância geográfica (HILAL, HEMAIS, 2003).

Uma desvantagem da Escola de Uppsala é que ela não considera como a percepção de distância psíquica pode afetar o processo de seleção de mercados em nível de decisor individual. Para esses autores, o estudo da percepção das similaridades e/ou diferenças é fundamental para o entendimento dos fatores que influenciam o processo decisório dos executivos. Nessa linha de raciocínio, a percepção do indivíduo pode ser afetada por diversos fatores, tais como a experiência acumulada, os antecedentes familiares, os idiomas que fala, o tempo de permanência no exterior, entre outros, que influenciam o construto de distância psíquica no momento da tomada de decisão (HILAL, HEMAIS, 2003; BORINI, COELHO, 
RIBEIRO, PROENÇA, 2004; RODRIGUES, MADEIRA, THEUER, MEDINA, FLEURY, 2006).

Segundo Ford (2002), os pesquisadores, na tentativa de destacar diferentes aspectos do marketing, tanto para canal como para internacionalização, abordam os mesmos temas: o marketing não é apenas algo que a empresa faz, mas um processo entre várias empresas, sem o controle de uma delas. Não se compõe de um conjunto de atividades, e sim como um processo ao longo do tempo, em que cada episódio afeta e é afetado por muitos outros episódios nos quais a empresa está envolvida, além daqueles de que ela participa à distância. Para o autor, a internacionalização é um fenômeno dos canais de distribuição e acontece em uma ampla rede. Assim, a melhor forma de compreender uma empresa e seu marketing não é olhar para a empresa, e sim para o conjunto dos relacionamentos dessa firma com outras.

Segundo Hilal e Hemais (2003), a distância psíquica percebida pelo executivo afeta sua análise de variáveis como barreiras à exportação, risco das operações, avaliação do potencial do mercado, confiança na possibilidade de sucesso, formação de networks sociais e políticas, entre outras.

\subsubsection{Industrial networks ou redes de relacionamento}

Segundo Ford (2002), a abordagem de redes foi empregada para prover de novas idéias o processo de internacionalização de empresas. Alguns dos trabalhos a respeito de redes fazem parte dos primeiros estudos sobre canais; outros relacionam-se com as pesquisa sobre internacionalização. Apesar das similaridades na literatura inicial a respeito desses temas, podem-se verificar também diferenças. Provavelmente, a diferença mais marcante, na literatura, entre as redes e os canais de distribuição é o fato de que o foco de redes recai sobre os conflitos entre empresas, enquanto o de canais de distribuição tem ênfase na cooperação, complementaridade e coordenação.

Para Ford (2002), a principal distinção entre a literatura sobre redes e sobre internacionalização é que os trabalhos mais recentes a respeito da internacionalização abordam a operação de uma única empresa e os resultados de suas tomadas de decisão. Ao contrário, a literatura sobre redes aborda a internacionalização das relações da empresa no país de origem ou no exterior, os relacionamentos que tem de estabelecer para poder operar 
em um novo mercado e as ações dessa empresa e das demais. Em outras palavras, a questão é entendida como um processo orientado por todos os atores que compõem a rede. Essa visão interativa evita que o foco recaia apenas no produtor como único influenciador e permite que se examine a totalidade da rede, considerando os seus varejistas, atacados, importadores, bancos.

Essa análise pode descortinar as dificuldades que uma empresa enfrenta para estabelecer uma posição em um novo mercado, em função das relações já existentes entre os atores da rede, que foram construídas ao longo do tempo. Similarmente, a entrada em um mercado envolve um complexo conjunto de relacionamentos, de modo que, em alguns mercados, as empresas se comportam como concorrentes e, em outros, cooperam umas com as outras, além de serem clientes e fornecedores entre si. Finalmente, a complexidade do desenvolvimento de mercados externos significa que as empresas precisam revisar suas ações continuamente em função das mudanças de condições. Esse fator faz com que seja extremamente difícil seguir um desenho predeterminado de orientação para a empresa, já que as condições não são facilmente previsíveis.

De acordo com Hilal e Hemais (2003), a abordagem de redes de relacionamento (networks) é considerada uma evolução natural do pensamento da Escola Nórdica. O papel central dessa perspectiva é focalizar os relacionamentos existentes entre firmas e mercados industriais. Os fatores e as forças competitivas em indústrias altamente internacionalizadas criam um padrão heterogêneo de oportunidades de entrada. Por esse motivo, a firma pode escolher mercados e estratégias de entrada bem diferentes do que é previsto pelo modelo tradicional de Uppsala. A estratégia de entrada associa-se ao estabelecimento de redes de relacionamento nos novos mercados a serem servidos. Os relacionamentos, tanto estritamente de negócios quanto pessoais, podem ser usados como pontes para a entrada em outras redes.

Do ponto de vista das networks, o contexto de negócios baseia-se principalmente em relacionamentos específicos entre atores. A teoria sugere que o grau de internacionalização de uma firma reflete não somente os recursos alocados no exterior, mas também o grau de internacionalização da rede em que ela está inserida. Assim, a internacionalização deixa de ser somente uma questão de mudança da produção para o exterior e passa a ser percebida mais como a exploração de relacionamentos potenciais além-fronteiras (HILAL, HEMAIS, 2003; BORINI, COELHO, RIBEIRO, PROENÇA, 2004). 


\subsubsection{Escola Nórdica de Negócios Internacionais}

De acordo com Hemais e Hilal (2004), a Escola Nórdica de Negócios Internacionais é como hoje a Escola de Uppsala é conhecida (Ilustração 12). A característica fundamental dos estudos dessa escola para o processo de internacionalização é o papel do empreendedor como fator-chave e força motriz.

Para Buckley (1990), os fatores econômicos, políticos e sociais afetam os negócios das multinacionais. O conceito de empreendedorismo compõe um sistema de teorias a fim de explicar o processo de internacionalização das empresas (HEMAIS, HILAL, 2004).

Segundo Schumpeter (1967), cada indivíduo julga a realidade a partir de seu ponto de vista. É o indivíduo quem é capaz de perceber e organizar recursos para transformá-los em ação. Conseqüentemente, o empreendedor é o responsável pelo desenvolvimento e a introdução de novos produtos, novos processos, novos recursos e novos mercados (HEMAIS, HILAL, 2004).

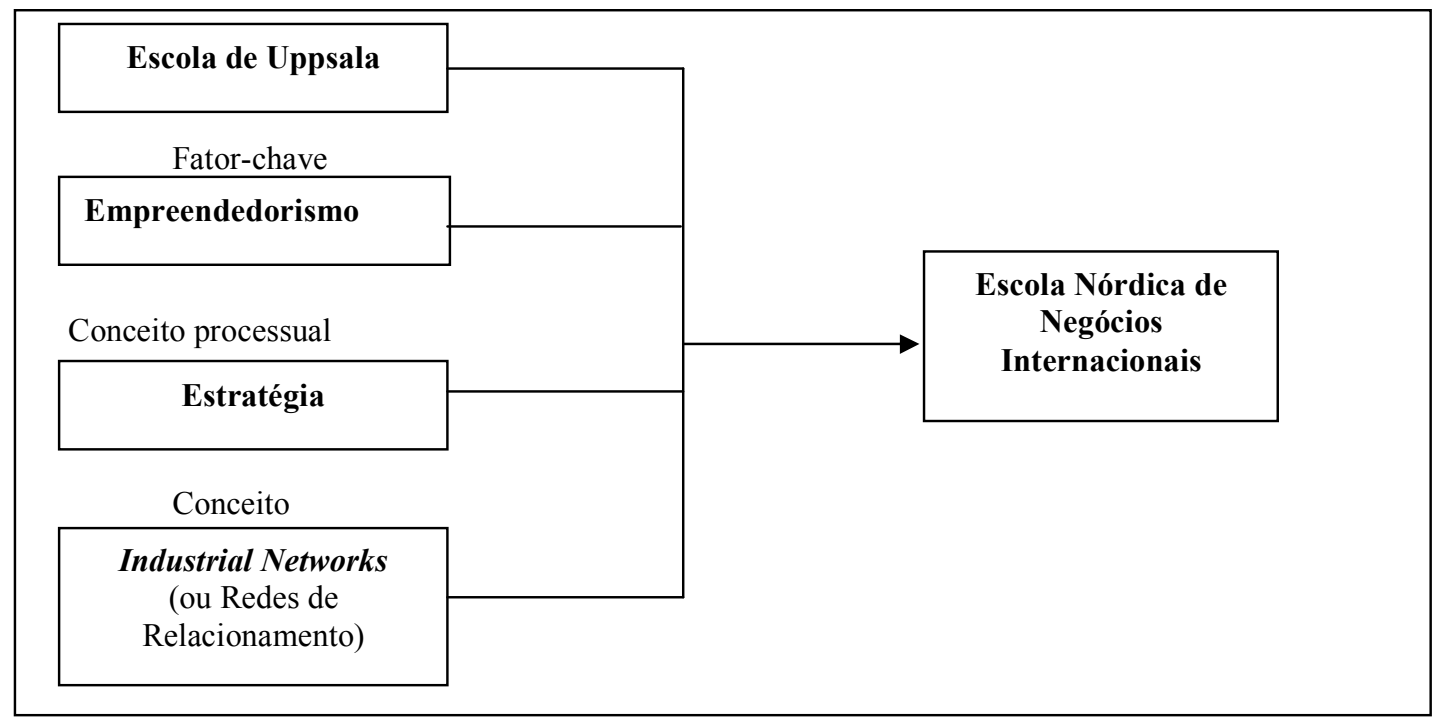

Ilustração 12 - Fundamentos da Escola Nórdica de Negócios Internacionais FONTE: HEMAIS e HILAL, 2004.

Hemais e Hilal (2004) chamam a atenção para o fato de que o fenômeno de internacionalização é complexo e por essa razão as teorias existentes sobre o tema não conseguem explicá-lo de maneira completa. Assim, os autores introduzem a ilustração do empreendedor no processo de internacionalização, empregando o conceito de empreendedor 
como uma ligação entre conceitos micro e macroeconômicos e conceitos processuais de estratégia e internacionalização. Dessa forma, a internacionalização não é uma atividade independente das demais de uma firma; origina-se da estratégia.

Para os mesmos autores, há três tipos de empreendedor. Um deles é chamado de empreendedor técnico e está voltado para a introdução de produtos e processos ou de uma fonte de suprimentos. A internacionalização se dá por meio de pedidos do exterior e, por essa razão, geralmente é adotada a exportação ou o licenciamento, uma estratégia do tipo international-pull. O segundo é o chamado empreendedor de marketing. Caracteriza-se pelo interesse na abertura de novos mercados, tendendo a internacionalizar seus negócios por meio de investimentos diretos nos novos mercados, com a construção de plantas de produção no novo local. Sua estratégia é a international-push. O último tipo é o empreendedor estrutural. Trabalha na reestruturação das empresas e vê a internacionalização como parte de uma estratégia maior. Geralmente, internacionaliza suas atividades por aquisição ou fusão (HEMAIS, HILAL, 2004).

Hemais e Hilal (2004) destacam que as teorias e os modelos atuais desejam explicar o fenômeno para qualquer tipo de firma, mas, em realidade, essas generalizações não dão conta da variedade de firmas existentes. Os autores sugerem que se desenvolva uma maneira de agrupar as firmas em categorias, além de conceitos e modelos para explicar o fenômeno em cada categoria. Ainda, recomendam que se utilize uma abordagem multidisciplinar para compreender a complexidade do fenômeno da internacionalização.

\subsection{Conceituação das teorias de internacionalização com base no enfoque gerencial}

\subsubsection{Teoria sobre Competição e Competitividade Global}

De acordo com Fleury e Fleury (2003), há uma abordagem clássica para a questão da competitividade das empresas. Ela se baseia na análise da indústria ou no posicionamento estratégico. $\mathrm{O}$ instrumento básico para o posicionamento estratégico inclui uma estrutura que se fundamenta nas "cinco forças" propostas por Michael Porter em 1980. Essa abordagem focaliza a análise dos mercados e da competição, buscando o entendimento da posição 
relativa de cada empresa em sua indústria ou segmento produtivo para a formulação da estratégia. O foco da análise recai sobre produtos, consumidores e competidores, e a estratégia da empresa deve ser resultante da identificação de tendências e oportunidades (Ilustração 13).

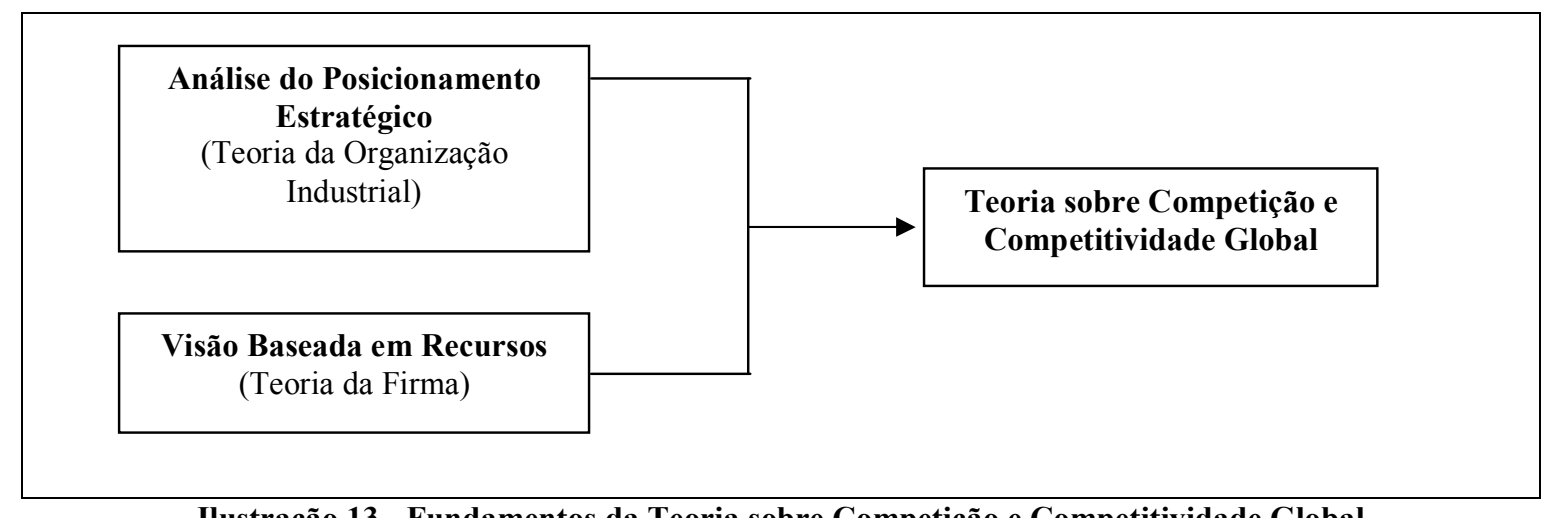

Ilustração 13 - Fundamentos da Teoria sobre Competição e Competitividade Global FONTE: FLEURY e FLEURY, 2003.

Saes (2007) e Fleury e Fleury (2003) chamam a atenção para outra abordagem sobre a competitividade das empresas, que tem seus alicerces na Visão Baseada em Recursos (Resources Based View). Consideram que toda empresa possui um portfolio de recursos físicos, financeiros, intangíveis (marca, imagem), organizacionais (cultura organizacional, sistemas administrativos) e recursos humanos - a partir dos quais pode criar vantagens competitivas.

Para Fleury e Fleury (2003), a estratégia competitiva pode ser classificada em três categorias: excelência operacional, inovação em produto e relação com o cliente. A estratégia de excelência operacional compõe-se de desenvolvimento e oferta no mercado de produtos (bens e serviços) que otimizem a relação entre qualidade e preço. A lucratividade da empresa é resultado da margem por produto e da escala de produção. A estratégia de inovação em produto relaciona-se ao contínuo desenvolvimento de conceitos de produto radicalmente novos para clientes e segmentos de mercado definidos. A função crítica dessa estratégia está na pesquisa e no desenvolvimento. A estratégia orientada para o cliente volta-se às necessidades de clientes específicos, buscando a especialização para o desenvolvimento de produtos, sistemas e soluções que atendam a suas demandas atuais e futuras. Para tal, as empresas focam o desenvolvimento do conhecimento sobre cada cliente e seu negócio, razão por que a função crítica passa a ser a área de vendas e de marketing. 
A importância do conhecimento e de competências para melhorar a competitividade da organização foi analisada por autores que elaboraram a visão da empresa baseada em recursos. Eles assumem que a vantagem competitiva sustentável depende de ativos tanto tangíveis quanto intangíveis, como o conhecimento. Muitas organizações falham ao entrar em um novo mercado porque lhes falta conhecimento e/ou não apresentam recursos ou competências (PAULA, PROENÇA, 2005).

Segundo Prahalad e Doz (1987), o que se deve analisar em empresas multinacionais é seu fluxo de capital e como ele pode ser coordenado. Os autores sugerem que a criação de diferentes missões estratégicas para cada país e distintos produtos e negócios em um mesmo país constitui um mecanismo para proteger o fluxo de caixa global. Essa estratégia é chamada de competitiva: o sucesso é determinado pela habilidade dos concorrentes em organizar e gerenciar variáveis sob seu controle. Os resultados advêm da habilidade relativa dos concorrentes em antecipar mudanças nos recursos empregados em um negócio e organizá-los de forma que possam ser explorados (PRAHALAD, DOZ, 1987).

As multinacionais podem abordar a estratégia como um processo de negociação com governos. As bases da vantagem competitiva no mercado de um país específico residem na habilidade dos gestores em negociar com o governo. São as estratégias negociadas. Outra tendência é a formação de alianças estratégicas entre firmas globais: ao mesmo tempo em que as firmas continuam competindo, elas colaboram entre si. É a chamada estratégia colaborativa (PRAHALAD, DOZ, 1987).

A estratégia competitiva geralmente se caracteriza por gestores com liberdade para tomar decisões que afetam as subsidiárias. As decisões relativas a produtos, preços, processos produtivos, escolha de pessoal, prioridades nas alocações dos recursos e timming das estratégias de mercado são de domínio da organização. Contudo, nas estratégias negociadas e colaborativas não se pode assumir que os gestores têm liberdade para mudar unilateralmente os elementos que compõem a estratégia, pois governos ou parceiros em alianças estratégicas podem reduzir sensivelmente essa liberdade (PRAHALAD, DOZ, 1987).

Uma implicação gerencial do uso alternado de tipos de estratégia é que os limites do negócio se tornam inexatos. Em um modelo competitivo os gestores têm o controle da maioria dos recursos de que precisam para o negócio ou para a firma. Em um modelo colaborativo as 
questões estratégicas são compartilhadas para além dos limites da organização e com firmas que podem ser ou se tornar concorrentes. A responsabilidade pelas ações e a natureza das transações entre os parceiros evoluem e podem se tornar ambíguas (PRAHALAD, DOZ, 1987).

O conhecimento de oportunidades, problemas, alternativas e ambiente aumenta de acordo com a experiência da empresa em determinado mercado. A demanda presente e futura, oferta, concorrência, canais de distribuição e condições de pagamento são fatores que variam de país para país. O conhecimento tácito pode ser obtido apenas através da experiência de conduzir as atividades relacionadas e permite melhorar a percepção para identificar oportunidades (HITT, IRELAND, HOSKISSON, 2002; PAULA, PROENÇA, 2005).

Segundo Saes (2007), as estratégias competitivas de grandes corporações internacionais (ocidentais e orientais) no curto prazo decorrem de seus atributos ligados ao preço e ao desempenho de produtos existentes. No longo prazo, há uma convergência para padrões similares de custo de produto e de qualidade, implicando a pouca importância de barreiras à competição como fontes de vantagens diferenciadas. As fontes de vantagens devem ser encontradas na capacidade de gerência para consolidar tecnologias em âmbito corporativo e nas habilidades de produção em competências que possibilitem negócios individuais para se adaptarem rapidamente às oportunidades em constante mudança.

\subsubsection{Análise do Posicionamento Estratégico}

Segundo Porter (1986), o foco do estudo sobre estratégia internacional deve ser a indústria, pois essa é a arena onde as vantagens competitivas são ganhas ou perdidas. O padrão de competição internacional varia de indústria para indústria e em função de ser multidoméstica ou global, em termos de escopo competitivo. Em indústrias multidomésticas, a competição em cada país é essencialmente independente da competição em outros países. O que caracteriza a firma multidoméstica é que, apesar de transferir conhecimento do país de origem para outro, modifica e adapta os ativos intangíveis para se ajustar às condições locais. Dessa forma, a vantagem competitiva da firma é específica do país onde atua. A indústria internacional se torna um conjunto de indústrias essencialmente domésticas. Indústrias que exibem esse padrão são o varejo, embalagens para produtos de consumo, distribuição e seguros. A indústria global é aquela cuja posição competitiva em um país é significativamente 
afetada por sua posição em outros países e vice-versa. A indústria global compõe-se por uma série de indústrias domésticas que estão interligadas e onde os concorrentes competem entre si em uma base realmente global. Indústrias que apresentam esse comportamento são as de TV, semicondutores, copiadoras, automóveis e relógios.

As implicações dessas diferenças para a estratégia internacional são profundas. $\mathrm{Na}$ indústria multidoméstica, a firma gerencia suas atividades internacionais por meio de portfolio. As subsidiárias, ou outra forma de operação no estrangeiro, devem controlar todas as atividades necessárias para fazer negócio na indústria em questão, além de deterem certo grau de autonomia. A estratégia adotada em um determinado país condiciona-se à estrutura competitiva existente, que Porter (1986) chama de concentração no país (country-centered) (PORTER, 1986).

$\mathrm{Na}$ indústria multidoméstica a competição internacional é ilimitada. A firma pode escolher tanto competir domesticamente quanto expandir-se internacionalmente, caso tenha alguma vantagem que supere os custos extras relacionados à entrada e competição em mercados estrangeiros. Os competidores serão empresas domésticas e multinacionais. Nas indústrias multidomésticas a estratégia internacional se reduz em função das diversas estratégias domésticas, ficando as questões de estratégia internacional restritas a como fazer negócio internacionalmente, como escolher bons países e como transferir conhecimento e habilidade (PORTER, 1986).

$\mathrm{Na}$ indústria global, o gerenciamento das atividades internacionais por meio de portfolio acaba gerando uma redução das possibilidades de conseguir vantagem competitiva. Nesse contexto, a firma precisa de alguma maneira integrar as atividades globalmente para capturar os vínculos entre países. Como a integração exige mais do que transferir ativos intangíveis entre países, a firma pode escolher competir usando a estratégia centrada no país, focando um segmento de mercado específico ou países onde identifica nichos de mercado, mas corre risco frente aos competidores que atuam usando estratégias globais. Na competição global a firma tem de executar algumas funções em cada país onde atua: um competidor global deve ver suas atividades como um amplo sistema e ainda manter uma perspectiva local para cada país. A questão fundamental na atuação global é o equilíbrio entre essas duas perspectivas (PORTER, 1986). 
A firma deve possuir dois tipos de vantagem competitiva, uma ligada ao baixo custo e outra, à diferenciação. Nesse sentido, o crescimento da firma relaciona-se à habilidade de atuar na cadeia de valor de maneira mais barata ou de forma ímpar em relação a seus competidores (PORTER, 1986).

O conceito de escopo competitivo (competitive scope) é fundamental para a construção da cadeia de valor. Quatro dimensões compõem o escopo competitivo: amplitude do segmento (segment scope), ou o intervalo de segmentos que a firma atende (variedade de produtos, tipos de consumidores); amplitude da indústria (industry scope), ou o intervalo de indústrias em que a firma compete com uma estratégia coordenada; amplitude vertical (vertical scope), ou as atividades que a firma pratica em relação a seus fornecedores e canais; e amplitude geográfica (geographic scope), ou regiões onde a firma opera com uma estratégia coordenada. O escopo competitivo é vital para a vantagem competitiva, pois modela a construção da cadeia de valor - como as atividades são estruturadas e de que maneira essas atividades são moldadas ao longo das unidades. A estratégia internacional é uma questão ligada à amplitude geográfica (geographic scope) (PORTER, 1986).

O fator diferenciador da estratégia internacional em relação à estratégia doméstica compõe-se de duas dimensões de como a firma compete internacionalmente. A primeira é a configuração das atividades da firma mundialmente ou a localização de cada atividade ao longo da cadeia de valor. A segunda dimensão é a coordenação, ou como as atividades desempenhadas em países diferentes estão ligadas (ou coordenadas) entre si. A firma, então, dispõe de uma variedade de possibilidades de configuração e coordenação para cada cadeia de valor. A configuração varia desde concentrada - desempenhar uma atividade em um local e servir o mundo - até dispersa - desenvolver uma atividade em cada país onde atua. Neste último caso, cada país terá uma cadeia de valor completa. As possibilidades de coordenação variam desde a ausência de coordenação até sua multiplicidade, em função das facetas que compõem cada atividade a ser coordenada (PORTER, 1986).

Os fatores que favorecem a concentração de uma atividade em um ou poucos locais para a partir dali servir o mundo são a possibilidade de economias de escala por atividade, a apropriação da curva de aprendizagem, a vantagem comparativa da atuação em um ou poucos locais e as vantagens de coordenação ao localizar atividades complementares. Por outro lado, os fatores que favorecem a dispersão relacionam-se à concentração dos custos. As 
necessidades para a produção de cada produto podem ser distintas em cada local em relação às vantagens de escopo ou de aprendizagem. A dispersão das atividades em um país pode facilitar as ações de marketing ao estabelecer comprometimento com os compradores locais. A dispersão também pode facilitar a aprendizagem ou o acréscimo de conhecimento na medida em que a existência de uma quantidade de localizações de determinada atividade facilita o fluxo de informações e coloca os gestores mais próximos de seus mercados. Pode ser ineficiente concentrar transportes, comunicação e estoques em um único local (PORTER, 1986).

Outro fator que favorece a dispersão é o governo de cada local, em função da diferença de tarifas, barreiras não-tarifárias ou outras ações regulatórias e legislativas. Geralmente os governos desejam que uma cadeia de valor esteja inteiramente em um só país. Diferentes países apresentam condições distintas, gerando, por essa razão, diferentes oportunidades de aprendizagem, desenvolvimento de atividades e de vantagens competitivas, o que leva à concentração de atividades ou a sua dispersão, dependendo do caso (PORTER, 1986).

Porter (1986) afirma que a estratégia internacional é sempre caracterizada pela escolha entre a padronização mundial e a adaptação local, ou seja, a tensão entre o determinante econômico (eficiência em função de larga escala) e o determinante político (produção local). Contudo, nenhuma das abordagens captura a complexidade das escolhas estratégicas internacionais da firma, pois esta envolve a busca de vantagem competitiva, que pode resultar da configuração e da coordenação global ao longo da cadeia de valor. A firma pode padronizar (concentrar) algumas atividades e adaptar outras (dispersar). Deve ser capaz de padronizar e adaptar ao mesmo tempo por meio da coordenação de atividades dispersas ou o uso da adaptação local de algumas atividades (diferentes produtos posicionados para cada país), a fim de proporcionar a padronização de outras produções. Da mesma maneira, o fator econômico não é sempre determinante para a estratégia global, já que em algumas indústrias a concentração no país é o determinante econômico. Inversamente, o determinante político em outras indústrias pode ser concentrar as atividades onde os governos promovem grandes incentivos à exportação e subsídios para a localização da indústria naquele país (PORTER, 1986). Em suma, as estratégias adotadas para a internacionalização não são padronizadas por tipo de negócio, mas condicionadas pelos fatores ambientais existentes no momento e no cenário vigente. 
A essência da estratégia internacional não é a permuta entre concentração e dispersão, mas sua eliminação ou mitigação, o que implica concentrar ou dispersar diferentes atividades, dependendo da estrutura da indústria: dispersar algumas atividades para permitir a concentração de outras e minimizar as permutas entre concentração e dispersão por meio da coordenação de atividades dispersas (PORTER, 1986). Contudo, Porter (1986) em nenhum momento fala sobre internacionalizar para anular a ação da concorrência ou ocupar os espaços para evitar o domínio de um concorrente, estratégia que se pode verificar na prática das firmas.

\title{
2.4.1.2 Visão Baseada em Recursos
}

A Visão Baseada em Recursos caracteriza-se por focar o mercado de fatores em detrimento dos produtos e fundamenta-se nos trabalhos de Penrose, Limits to the Growth and Size of Firms (1955) e The Theory of the Growth of the Firm (1959). Para a Visão Baseada em Recursos, a principal origem da vantagem competitiva das empresas é a posse de recursos estratégicos:

\begin{abstract}
A firma é uma unidade administrativa que vai gerir um conjunto de recursos tangíveis e intangíveis necessários para produzir bem e serviços. Os gestores têm uma imagem do ambiente e do resultado dos recursos externos a serem empregados. Essa imagem vai sendo construída por um processo de aprendizagem e determina a mudança na coleção de oportunidades produtivas da firma. $\mathrm{Ou}$, em outras palavras, a firma é uma coleção de recursos de conhecimento, que estão envoltos em rotinas e processos. (SAES, 2007, p. 13).
\end{abstract}

São os recursos que possibilitam à firma alcançar seu objetivo de obter vantagens competitivas sustentáveis. As vantagens surgem quando as firmas desenvolvem ou adquirirem um conjunto de recursos que são superiores aos de seus concorrentes. $\mathrm{O}$ emprego dos recursos na criação das estratégias determina seus pontos fortes e fracos (SAES, 2007). Saes (2007) destaca a distinção entre recursos e capacidades (capabilities), feita por alguns autores, que chamam de capacidades as habilidades baseadas em competências humanas, e de recursos, quaisquer outros ativos.

A essência da firma compõe-se de sua habilidade de criar, transferir, reunir, integrar e explorar os recursos, e cada firma os utiliza de maneira diferente, em consonância com as diferentes percepções e estratégias dos gestores. O resultado é a heterogeneidade das firmas e, por conseguinte, diferentes rentabilidades entre elas. Uma das principais fontes das diferenças 
de rentabilidade entre as firmas no equilíbrio decorre de rendas no sentido ricardiano, isto é, retorno superior ao custo de oportunidade. Ou seja, as rendas econômicas em firmas eficientes originam-se de insumos escassos e das imperfeições do mercado de fatores. Essas imperfeições surgem da habilidade gerencial, da estrutura e da cultura organizacional específica de cada firma, além de ativos tangíveis, como produtos e inovação, e ativos intangíveis, como confiança do consumidor, imagem da marca, reputação (SAES, 2007).

\subsubsection{Abordagem sobre Gestão Estratégica de Operações}

A Abordagem sobre Gestão Estratégica de Operações baseia-se no pragmatismo com que a firma faz escolhas entre um número de variáveis relacionadas à decisão de internacionalizar e os métodos que adota para que a internacionalização aconteça (Ilustração 14). Os fatores que devem ser avaliados para a seleção do mercado incluem atratividade, distância psíquica, acessibilidade e barreiras informais, enquanto a escolha da estrutura organizacional para atuar no mercado depende das características desse mercado, bem como de fatores específicos relacionados à empresa: seu histórico de comércio internacional, seu tamanho, a orientação da exportação e o comprometimento. O número de concorrentes é o fator-chave que afeta a entrada nesse mercado (WHITELOCK, 2002).

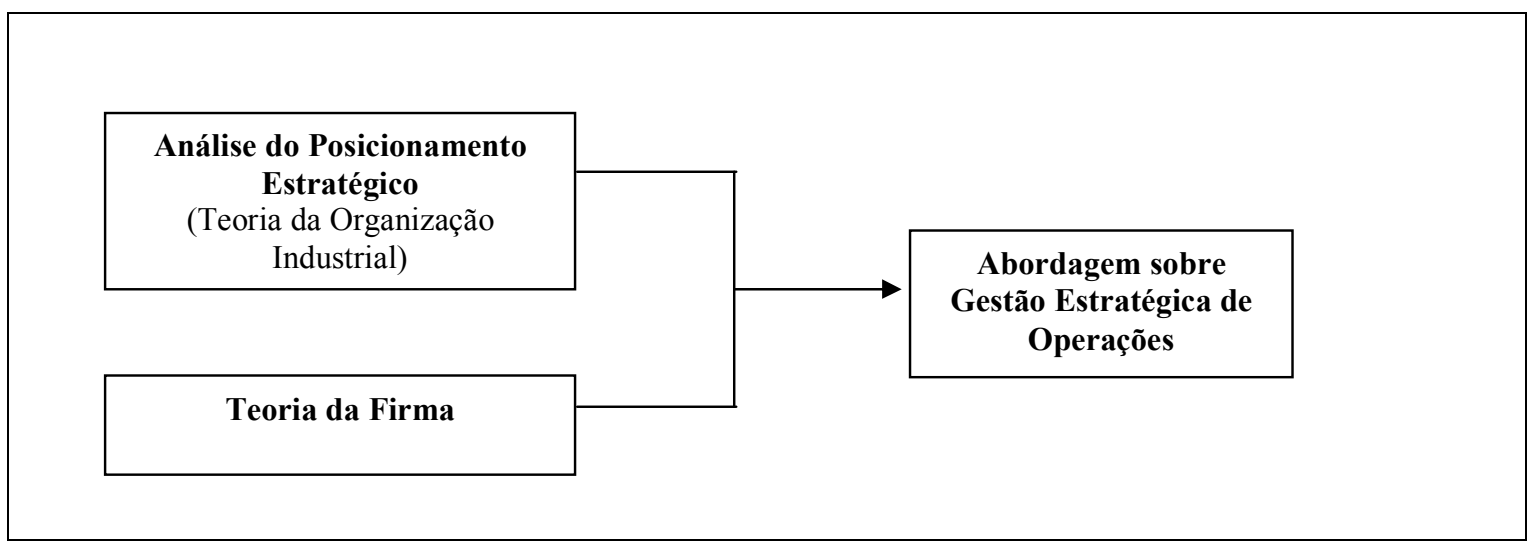

Ilustração 14 - Fundamentos da Abordagem sobre Gestão Estratégica de Operações

Segundo Shi (2003), apesar de as operações internacionais serem o centro dos negócios internacionais e da gestão estratégica, não se transformaram em um sistema operacional com capacidade para lidar com as questões práticas ligadas à estratégia e à operação. Esse fenômeno decorre de fatores históricos e metodológicos que criam uma lacuna entre os negócios internacionais, a gestão estratégica e a gestão de operação internacional. Nesse 
sentido, faz-se necessária uma outra perspectiva para compreender a natureza das operações internacionais. A operação de empresas no ambiente internacional requer a percepção de que se trata de uma rede de relacionamentos internacionais. Em função desse desenho devem-se levar em conta as questões relativas à dispersão geográfica, à coordenação horizontal, ao posicionamento vertical e à integração entre os atores como características críticas dessas redes.

Para Bartlett e Ghoshal (1988), o ambiente internacional para operação das empresas vem se tornando mais complexo a cada dia. As empresas tentam imitar as características e estratégias organizacionais de seus concorrentes; porém, as demandas internacionais não podem ser atendidas por uma fórmula. Operar internacionalmente exige mais do que uma administração central eficiente e uma operação local flexível. Requer empresas que sejam capazes de lidar com uma diversidade organizacional e de recursos de maneira a alavancar suas capacidades para chegar à coordenação global e, simultaneamente, à flexibilidade nacional. Em resposta a essa necessidade, algumas empresas desenvolveram o conceito de capacidade transnacional, que vai além da abordagem multinacional ou global dos negócios internacionais. A capacidade transnacional pode ser definida como a habilidade de se gerenciar além-fronteiras. Dessa maneira, operar internacionalmente é mais do que simplesmente reproduzir a atuação local ou de algum modelo desenvolvido por concorrentes. Envolve a percepção de que se trata de estabelecer relações entre atores, organizar redes de relacionamentos. Essas redes precisam lidar com duas dimensões críticas: a dispersão geográfica e a necessidade de coordenação entre as partes. O resultado será um desenho de operação específico para cada firma em função do ambiente, dos atores, dos concorrentes e dos recursos disponíveis.

\subsubsection{Abordagem sobre Gestão de Competências}

O conceito de competência organizacional origina-se da abordagem da Visão Baseada em Recursos (Ilustração 15). Nesse sentido, a firma se compõe por um potfolio de recursos físicos (infra-estrutura), financeiros, intangíveis (marca, imagem junto ao cliente), organizacionais (cultura organizacional, sistemas administrativos) e recursos humanos (FLEURY, FLEURY, 2004).

Para Prahalad e Doz (1987) e Hitt, Ireland e Hoskisson (2002), a competência estratégica em uma multinacional é a competência inerente à organização para continuadamente aprender 
com o ambiente, desenvolver respostas apropriadas (estratégias) e mobilizar seus recursos a fim de competir. Representa a existência de uma infra-estrutura gerencial que facilita o desenvolvimento de uma estratégia efetiva e sua implementação. A competência estratégica requer que a organização construa uma estrutura formada por diversas dimensões: competência em processos de informação, sistemas de gerenciamento diversificados para lidar com as diversas estratégias, competência em mudar as estratégias de acordo com as mudanças do ambiente, capacidade de gerenciar a inovação, ter e desenvolver qualidade dos processos executivos e, apesar da variedade de sistemas de gerenciamento, disponibilizar estabilidade emocional, intelectual e de princípios.

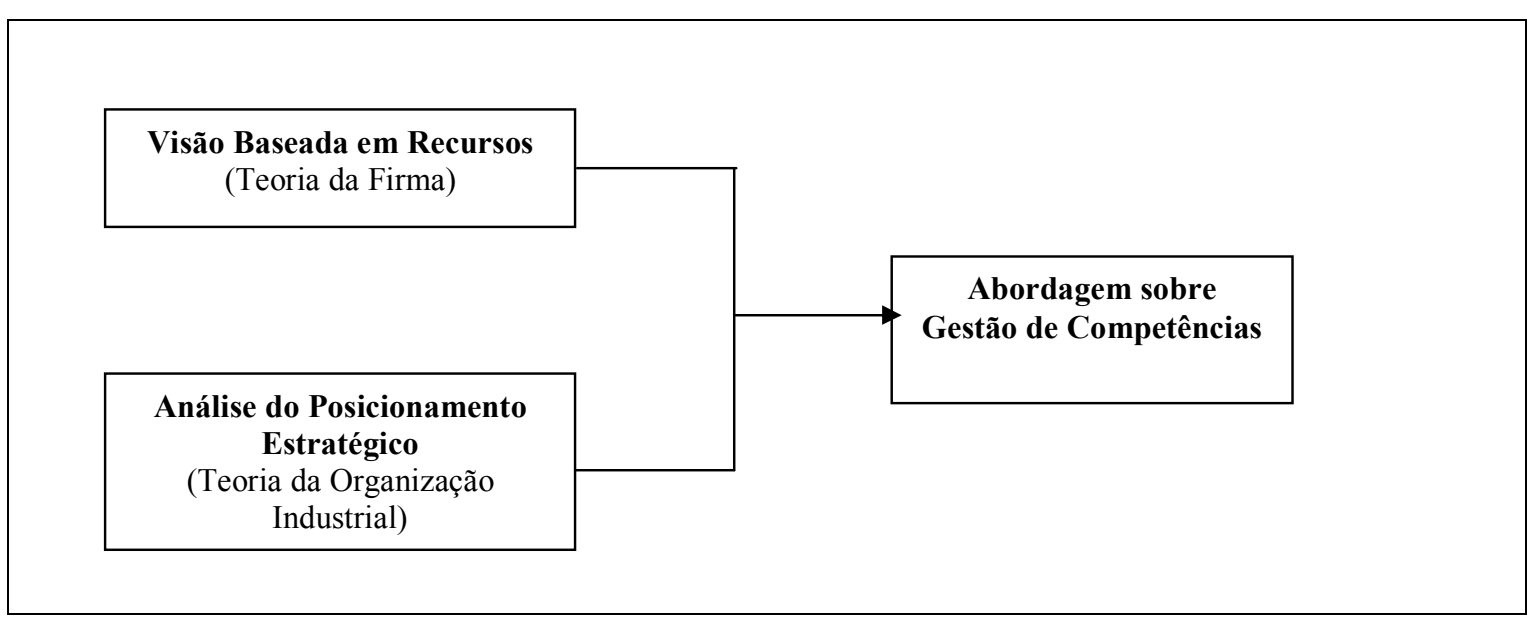

Ilustração 15 - Fundamentos da Abordagem sobre Gestão de Competências

Fleury e Fleury $(2003 ; 2004 ; 2005)$ afirmam que o mais importante fator na estruturação de redes interorganizacionais internacionais são as competências organizacionais. Assim sendo, a participação e a posição de cada empresa é função de suas competências. A posição na rede e a forma pela qual as competências são administradas influenciam, por sua vez, as estratégias competitivas. No ambiente em constante mudança e na conseqüente reestruturação das empresas a competitividade depende de eficiência coletiva. Por outro lado, cada empresa tem de focar suas competências essenciais (core competences) e, por meio de parcerias, adquirir os recursos inexistentes na firma e necessários para realizar seus objetivos. Chamam-se competências essenciais os recursos intangíveis difíceis de ser copiados pelos concorrentes e fundamentais para a empresa poder proporcionar produtos (bens e serviços) diferenciados para os mercados e os clientes. As competências essenciais são o fator que permite explorar mercados distintos e estão ligadas à própria mudança e evolução da empresa. $\mathrm{O}$ 
desenvolvimento de competências essenciais envolve um processo sistemático de aprendizagem e inovação organizacional.

Qualquer empresa possui competências relacionadas às funções de operações (produção e logística), desenvolvimento de produto e comercialização (vendas e marketing). As competências devem ser desenvolvidas tendo em vista reforçar a competência essencial. A competitividade será maximizada quando houver alinhamento correto entre competência essencial e estratégia competitiva (FELURY, FLEURY, 2003; 2005).

Knight e Cavusgil (2004) sustentam que a habilidade de ser a primeira empresa de um determinado setor a se internacionalizar e obter sucesso em mercados externos é função da capacidade interna da firma (capability). A habilidade de determinadas firmas para inovar acaba por criar conhecimentos necessários para desenvolver capacidades organizacionais, que consistem nas competências críticas e rotinas.

\subsubsection{Abordagem sobre Gestão do Conhecimento}

O conhecimento é recurso importante e a integração dos conhecimentos especializados individuais constitui a essência das capacidades organizacionais (KNIGHT, CAVUSGIL, 2004). O conhecimento relaciona-se fundamentalmente à ação humana, mas, embora sejam os indivíduos quem cria conhecimento, é a organização que gera o ambiente para o conhecimento ser criado e ampliado. A aquisição de um conhecimento resulta do compartilhamento de experiências e da aprendizagem entre os membros da organização. (LYLES, SALK, 1996).

A Abordagem sobre Gestão do Conhecimento (Ilustração 16) sustenta que o conhecimento proporciona uma vantagem particular, pois facilita a entrada e a operação em mercados externos. Esse conhecimento refere-se à capacidade que a firma tem de aprender e usar os relacionamentos para conseguir determinados resultados. As capacidades organizacionais refletem a habilidade da firma para atuar repetidas vezes ou reproduzir tarefas relativas às suas capacidades para criar valor por meio da transformação de insumos em resultados. Nesse sentido, o recurso mais importante é o conhecimento único, inerente a cada firma individualmente e difícil de ser copiado e transmitido. O conhecimento organizacional deriva 
de múltiplas fontes individuais. Contudo, é mais do que a soma de cada parte e se torna o principal fator estratégico (KNIGHT, CAVUSGIL, 2004; OLIVEIRA, FLEURY, 2004).

A Visão Baseada em Recursos ajuda a explicar como, em um ambiente de cultura inovadora, o conhecimento e as capacidades organizacionais resultantes são desenvolvidos e a ação empreendedora é alavancada. A existência de recursos diferenciados é um importante determinante das capacidades e do desempenho de uma empresa (KNIGHT, CAVUSGIL, 2004).

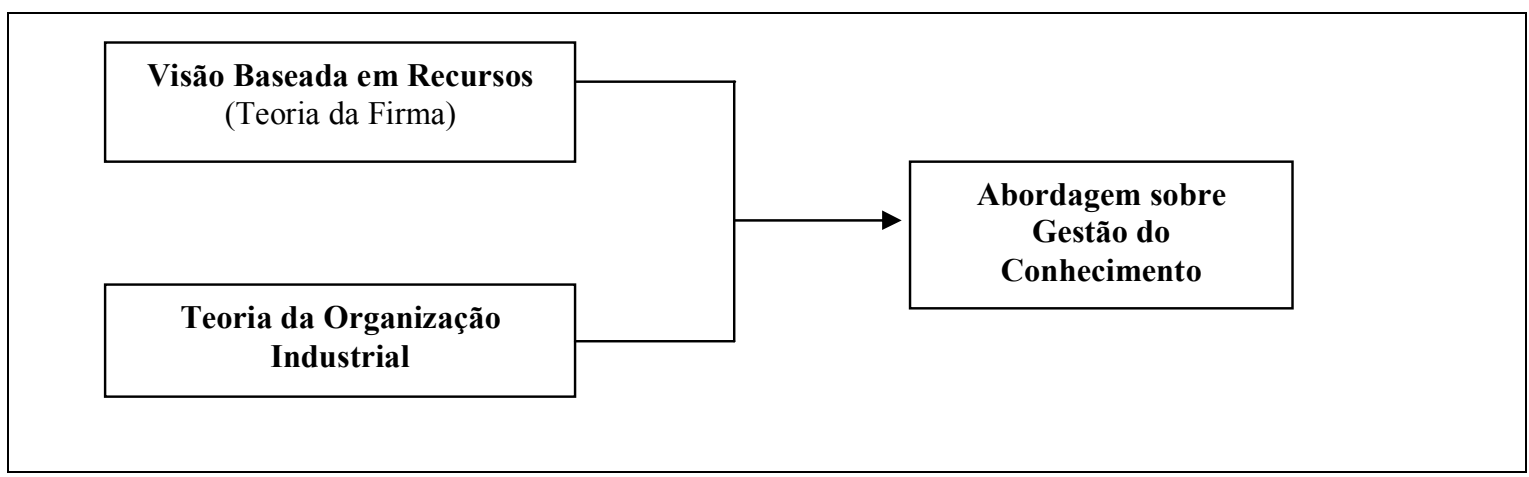

Ilustração 16 - Fundamentos da Abordagem sobre Gestão do Conhecimento

O fluxo de conhecimento relaciona-se intimamente ao desenho da estrutura e de controle entre matriz e subsidiária. As diferenças nos contextos estratégicos das subsidiárias implicam estruturação de tarefas diferentes para os gestores em termos de grau de interdependência, nível de responsabilidade e autoridade globais, e a necessidade de iniciativa local. A existência de tarefas diferentes em função do ambiente leva à necessidade de comportamentos distintos por parte dos gestores de cada subsidiária. Em conseqüência disso, a existência de mecanismos de controle diferentes induz e representa o alicerce para a formação de distintos comportamentos dos gestores (GUPTA, GOVINDARAJAN, 1991).

\subsection{Conceituação da teoria de internacionalização com base no enfoque cultural}

\subsubsection{Abordagem Intercultural}

As áreas de interesse das pesquisas sobre negócios internacionais têm sido economia, legislação, formatos e estruturas organizacionais; porém, a importância da cultura nacional - 
definida como valores, crenças, normas e padrões de comportamento de um grupo - tem se tornado mais relevante nas últimas duas décadas, em função dos trabalhos de Hofstede (2003). A cultura nacional tem impactado a maioria das atividades de negócio, desde as estruturas de capital até o desempenho dos grupos (LEUNG, BHAGAT, BUCHAN, EREZ, GIBSON, 2005). Esse é o foco da Abordagem Intercultural (Ilustração 5).

A teoria social examina comumente a relação entre o indivíduo e seu grupo e a cultura nacional. Contudo, o ambiente global cria uma nova entidade coletiva e ao mesmo tempo impessoal que afeta a identidade de cada pessoa. Entende-se por identidade global o senso de pertencer a um determinado grupo, os estilos de vida e as informações que o indivíduo passa a ter e que são parte de uma cultura global. Contudo, em paralelo, esse indivíduo continua a ter sua identidade local, baseada na socialização que se dá no âmbito da cultura local. Nesse sentido, cada indivíduo passa a ter uma identidade bicultural, composta em parte pela cultura local e em parte por uma cultura global. A natureza dupla dessa identidade representa um desafio para a operação das multinacionais, já que se conhece pouco a complexidade dos processos que cercam a identidade dos indivíduos (LEUNG, BHAGAT, BUCHAN, EREZ, GIBSON, 2005).

É importante compreender as diferenças no modo de pensar, sentir e atuar dos líderes e seus seguidores para encontrar soluções viáveis em escala mundial. Apesar da enorme diversidade de mentes, pode-se encontrar uma estrutura que sirva de ponto de partida para a compreensão mútua (HOFSTEDE, 2003).

Cada indivíduo pertence a vários grupos ou categorias simultaneamente, e por esse motivo é portador de diferentes níveis de programação mental, que correspondem a diferentes níveis culturais (HOFSTEDE, 2003):

a) um nível nacional, relativo ao país a que pertence (ou países, para pessoas que emigram);

b) um nível ligado ao grupo regional, étnico, religioso ou lingüístico;

c) um nível ligado ao sexo masculino ou feminino;

d) um nível de geração (avós, pais e filhos);

e) um nível relativo à origem social, ao grau de escolaridade e à profissão exercida;

f) um nível ligado à organização ou empresa onde o indivíduo trabalha e à forma como os trabalhadores se socializam. 
O autor (HOFSTEDE, 2003) emprega as categorias de problemas para designar as dimensões das diferentes culturas. Essas categorias são: 1) relação com a autoridade; 2) concepção do "eu" (relação do indivíduo com a sociedade; conceito de masculinidade e feminilidade); 3) formas de gerir conflitos, incluindo o controle da agressão e a expressão de sentimentos. As dimensões correspondentes são chamadas, respectivamente, de distância hierárquica, grau de individualismo (ou coletivismo), grau de masculinidade (ou feminilidade), controle da incerteza.

Esse conjunto forma um modelo de quatro dimensões das diferenças entre as culturas nacionais. Cada país, de acordo com esse modelo, caracteriza-se por um resultado para cada uma das dimensões. Há ainda uma quinta dimensão - orientação a longo prazo e orientação a curto prazo - que não fazia parte do modelo anterior em função de uma visão mais ocidental do problema (HOFSTEDE, 2003).

As dimensões da cultura e a criação de valor baseiam-se em dois conceitos: cultura organizacional e cultura profissional. O primeiro conceito refere-se à forma como as organizações se desenvolvem. No caso de negócios internacionais, adquire a dimensão de cultura organizacional nacional e inclui os aspectos que a empresa absorveu em seu país de origem e está levando para o país hospedeiro. O segundo conceito focaliza a cultura individual das pessoas a serem expatriadas e inclui a bagagem cultural absorvida por elas no seu dia-a-dia (SIRMON, LANE, 2004). A efetividade da conjunção da cultura nacional e da cultura profissional deve ser avaliada quando da realização de negócios internacionais e da colocação dos bens ou serviços no país hospedeiro (RODRIGUES, MADEIRA, THEUER, MEDINA, FLEURY, 2006).

A distância cultural é um construto amplamente empregado em negócios internacionais, aplicado na expansão de investimentos no estrangeiro, nos modos de entrada e no desempenho de filiais estrangeiras. Contudo, por sua natureza complexa, intangível e sutil, a cultura tem sido difícil de conceituar e medir. Estabelecer uma medida para a distância cultural é um desafio ainda maior: o conceito apresenta distorções como a ilusão de simetria, estabilidade, linearidade, casualidade, discordância, além das falhas metodológicas envolvendo a suposição de homogeneidade empresarial e geográfica. A fim de trazer maior rigor ao conceito, deve-se considerar que (SHENKAR, 2001): 
a) países podem apresentar diferenças culturais significativas em função de serem mais ou menos abertos;

b) a proximidade física não reduz especificamente a distância cultural, mas facilita o contato, a coordenação, os transportes e o controle, e nesse sentido acaba por reduzir a possibilidade de falhas no processo de entrada;

c) a experiência prévia de internacionalização pode ser importante principalmente em função da experiência dos gestores;

d) a aculturação (mudanças no sistema resultantes da difusão de elementos culturais em ambas as direções - elementos do país de origem e do país de entrada) se dá como forma de ajuste antes mesmo da entrada em um outro país, ou seja, tanto os indivíduos como as empresas procuram antecipar os ajustes em função da distância cultural antes de se verem na nova situação, que no caso é a entrada em um novo país;

e) a facilidade de comunicação (muito em função da comunicação por computadores, Internet) não reduz as distâncias culturais, e sim faz com que o indivíduo perceba mais nitidamente as diferenças existentes no mundo;

f) algumas culturas são consideradas atrativas em função de atributos que não são especificamente relacionados à proximidade cultural;

g) os gestores a serem expatriados constituem fator fundamental para o sucesso da entrada em outros países, pois trazem consigo a cultura de seu país (origem), da empresa e de suas diversas experiências em situações anteriores.

\subsection{Conclusão das teorias e abordagens sobre internacionalização}

A maioria das teorias sobre internacionalização tem suas bases nas rotas das organizações e da economia industrial a partir de Coase (1937), nos anos 30, Bain (1959) e Penrose (1955, 1959), nos anos 50, e Williamson (1971), nos anos 70. As teorias sobre internacionalização foram desenvolvidas nos anos 70 e 80 , quando as multinacionais americanas começaram a investir na Europa e as empresas européias começaram a exportar principalmente para os países vizinhos.

Desde o surgimento dessas teorias o mundo mudou mais rapidamente. Como resultado, é preciso examinar essas teorias de maneira crítica, mesmo que ainda possam ajudar nas questões práticas da internacionalização das firmas de hoje. Quando as teorias foram 
construídas o ambiente onde atuavam as firmas era diferente. Assim sendo, devem-se levar em conta as mudanças, o novo ambiente onde as firmas atuam hoje, e rever a conceituação das teorias.

Para Axinn e Matthyssens (2002), a teoria existente sobre internacionalização é insuficiente para explicar o comportamento das firmas em mercados internacionais. Segundo os autores, é fundamental examinar o impacto da economia global, economia de serviço (service economy), nova economia, economia da alta tecnologia, conhecimento e relacionamento, e economia do valor (value economy) na mudança da forma dos relacionamentos dos negócios internacionais. Por outro lado, é necessário retomar as teorias tradicionais, a fim de explorar as questões relacionadas à velocidade da internacionalização, aos limites da distância psíquica, à variedade de modos de entrada estabelecidos, às unidades de análise empregadas, à ausência de lógica na relação dos tipos de aprendizagem por meio da experiência, ao foco da produção, ao despreparo da gerência e à incorporação do valor do cliente. Devem-se ao mesmo tempo adaptar os modelos existentes e desenvolver novos modelos teóricos.

Os autores destacam que as teorias existentes sobre internacionalização são inadequadas para explicar ou predizer, sozinhas, o comportamento das firmas atualmente. Ao longo da última metade de século, muitas teorias foram desenvolvidas a fim de explicar o comportamento das firmas na arena internacional (AXINN, MATTHYSSENS, 2002):

a) em termos do crescimento da expansão nos mercados exportadores;

b) em termos do aumento do capital investido ao redor do globo;

c) em termos das decisões tomadas pelas firmas, com aumento das possibilidades de escolha de modos de entrada para acessar mercados estrangeiros.

Hoje em dia, as firmas estão se internacionalizando em muito maior quantidade e muito mais rapidamente do que antes. Conseqüentemente, as teorias que podem fornecer orientação prática para as firmas são mais críticas do que antes. Além disso, as empresas estão se internacionalizando de maneiras muito distintas do que faziam anteriormente, em geral usando a combinação de estratégias de entrada e de saída. As firmas menores, especialmente as de alta tecnologia, costumam praticar modos avançados de entrada no início. Serviços e experiência são negociados por todo o mundo. Na Europa, a desregulamentação proporcionou a expansão das empresas de serviço público (nation-bound utilities) e das agências governamentais para países vizinhos. Economias emergentes e em transição, como é o caso 
do Brasil, estão se abrindo em velocidade sem precedentes e suas empresas estão entrando nos negócios internacionais (AXINN, MATTHYSSENS, 2002).

Cada teoria foi desenvolvida em um contexto específico e para explicar um conjunto determinado de comportamentos de firmas. Porém, dado que o contexto mudou, a habilidade de cada teoria, que era razoavelmente adequada para explicar os comportamentos no ambiente em que foram criadas, é insuficiente para explicar os comportamentos observados hoje (AXINN, MATTHYSSENS, 2002).

As premissas básicas e as doutrinas de cada teoria têm de ser avaliadas com base na nova realidade econômica, que desafia as proposições das teorias tradicionais, impondo limitações a sua aplicação para explicar o comportamento das firmas hoje em dia, que se caracterizam por (AXINN, MATTHYSSENS, 2002):

a) rapidez de internacionalização;

b) limitações da distância psíquica;

c) acomodação das opções de modos de entrada;

d) ausência de lógica nas atividades;

e) aprendizagem pela experiência;

f) foco em produção (manufatura);

g) avaliação inferior da gerência e dos valores relevantes para os acionistas;

h) incorporação do valor do consumidor.

Algumas advertências se fazem necessárias. Primeiramente, há relação entre as tendências identificadas com a obstrução, focando um aspecto a cada momento. Segundo, o conceito de internacionalização precisa ser ampliado: implica, hoje em dia, um complexo processo de aprendizagem, organização do conhecimento e dos recursos no estrangeiro, integração da perspectiva multicultural nas redes internas e externas, gerenciamento do portfolio regional e composição de um valor da marca que contemple tanto a perspectiva do acionista quanto a do consumidor (AXINN, MATTHYSSENS, 2002).

O ambiente onde as firmas atuam mudou sensivelmente nos últimos 50 anos e as obrigou a rever seu comportamento para sobreviver e prosperar em meio à competição acirrada e em ambiente globalizado. A globalização da economia resulta da convergência de um grande número de mudanças que impulsionam o fenômeno da internacionalização. Nota-se 
particularmente o crescimento de uma economia dos serviços, na qual a Internet desempenha papel importante, com mercados de alta tecnologia e baseados, muitas vezes, na estrutura de redes.

Diversas estruturas conceituais têm sido usadas para explicar a dinâmica da internacionalização. Observando as estruturas de organização das teorias e abordagens apresentadas por distintos autores, verifica-se uma multiplicidade de proposições. Variam em número de conceitos, sua classificação e o relacionamento entre eles. A estruturação do referencial teórico pode ser ordenada de maneiras diferentes, de acordo com o autor que a propõe. Vários estudos sobre internacionalização têm sido realizados no âmbito das pesquisas acadêmicas nacionais e internacionais; entretanto, a maioria deles se concentra em adotar uma das teorias para explicar a internacionalização da empresa.

Apesar dos esforços acadêmicos para organizar as bases teóricas, a literatura ainda apresenta lacunas quanto à sistematização de uma estrutura teórica que possa dar suporte às pesquisas e à prática da internacionalização das empresas. O conceito de internacionalização e sua fundamentação teórica precisam ser ampliados, a fim de contemplar a diversidade dos negócios internacionais, bem como as novas condições que o ambiente impõe.

\subsection{Teorias e abordagens sobre internacionalização do varejo}

Os modos de entrada e a escolha dos mercados externos têm figurado entre os principais tópicos em pesquisas relacionadas aos negócios internacionais das indústrias manufatureiras durante as últimas duas décadas. Entretanto, a expansão internacional da indústria de serviços e, conseqüentemente, do varejo, tem se tornado mais pronunciada em anos recentes. Conhecese relativamente pouco sobre as escolhas internacionais do varejo. Geralmente se assume que as indústrias entram em mercados externos para explorar vantagens de localização relativas aos custos de produção e ao acesso a recursos, enquanto as empresas de varejo entram em mercados internacionais motivadas pelos fatores relacionados à demanda (GRIPSRUD, BENITO, 2005). Outro ponto a ser considerado é que as indústrias podem iniciar seu processo de internacionalização por meio da exportação, opção que não faz sentido para o varejo, que tem como característica levar ao consumidor os produtos; assim sendo, a presença física no 
país é indispensável. No caso na Internet, a presença física assume o formato de um website (STERNQUIST, 2007).

Os motivos que levam as empresas de varejo a se internacionalizarem foram identificados por meio da observação direta e de pesquisas empíricas. Contudo, apontam apenas para temas relacionados à metodologia e à complexidade do processo de desenvolvimento. Nos anos 80, a combinação de fatores econômicos, políticos, sociais e do próprio varejo conduziu os pesquisadores a afirmarem que a internacionalização acontecia em virtude da limitação de oportunidades nos mercados domésticos. Entretanto, as pesquisas mais recentes mostram que a internacionalização do varejo tem um caráter mais proativo do que reativo, ou seja, constitui um processo de identificação de oportunidades, e não apenas um fruto de limitações do mercado doméstico. Mostram, ainda, que a internacionalização não é um processo totalmente novo, mas condicionado a fatores existentes em cada período (ALEXANDER, 1995).

As direções da internacionalização do varejo têm recebido considerável atenção da literatura. Contudo, ficou estabelecido e aceito como princípio que o varejo inicialmente procura mercados com proximidade geográfica antes de se deslocar para mercados mais distantes e distintos durante seu processo de expansão internacional. Esse princípio de expansão do varejo internacional reflete o movimento das atividades varejistas de mercados desenvolvidos para outros mercados desenvolvidos ou de mercados desenvolvidos para outros menos desenvolvidos. Igualmente, pesquisas sobre a atitude dos varejistas frente a oportunidades em mercados internacionais têm suportado a conclusão de que os varejistas procuram ambientes mais familiares antes de se deslocarem para mercados distantes (ALEXANDER, SILVA, 2002).

\subsubsection{Fatores que interferem na internacionalização do varejo}

Um dos primeiros trabalhos sobre a internacionalização do varejo é de Hollander (1970), que aponta algumas das principais razões para se internacionalizar, enfatizando a necessidade de estabilidade política e destacando a importância dos fatores sociais, políticos e éticos, ou seja, fatores não-comerciais. Os objetivos por trás da internacionalização podem ser: comercializar com países sob a forma de importação ou exportação para desenvolver operação internacional; expandir-se de forma defensiva, movendo-se para outro mercado, a fim de evitar a expansão de concorrentes; iniciar operação em outro país, a fim adquirir 
conhecimento e obter informações de mercados externos (BROWN, BURT, 1992; ALEXANDER, 1995). Hollander (2000) também afirma a necessidade de analisar de que maneira o comércio eletrônico afeta o foco do varejo, descortinar as condições que fazem um determinado país ser receptivo ou hostil a negócios internacionais e avaliar quando se deve entrar em um novo local por investimento direto ou por meio de franquia.

Desde o final dos anos 70, os estudos a respeito da internacionalização do varejo focalizam principalmente as dimensões geográficas, com ênfase nos fluxos de investimentos internos e externos em um determinado mercado. São trabalhos desenvolvidos fundamentalmente por estudiosos europeus a respeito de movimentos de internacionalização de empresas européias. Estudos monitorando o volume, o tipo e a natureza da internacionalização do varejo são em menor número quando comparados aos trabalhos que analisam o processo que os envolve. Os temas recorrentes nessa área focam os motivos que estimulam a atividade internacional e os mecanismos gerenciais próprios para essa atividade. Os primeiros trabalhos remontam à metade dos anos 60, concentrando-se nas questões estratégicas, principalmente no reconhecimento dos fatores que empurram (push factors) e puxam (pull factors) os movimentos internacionais. Um primeiro fator que contribui para a compreensão da internacionalização do varejo é o tempo. De modo geral, esses estudos, que se iniciaram na década de 70, apresentam essa dimensão implicitamente. A perspectiva temporal contribui para o debate a respeito das mudanças nos direcionamentos geográficos, nos modos de entrada e no comportamento gerencial. Um segundo fator relaciona-se à disponibilidade de dados sobre o mercado: concorrentes, consumidores, fornecedores. O acesso a essas informações, que se iniciou anos 60, facilita o monitoramento das condições ambientais para o deslocamento internacional. Ainda um fator deve ser levado em conta quando se analisa a internacionalização do varejo: as diferenças na maneira de abordar mercados internacionais refletem-se nos distintos modos de entrada utilizados e têm suas bases nas características de cada setor do varejo, ou seja, a natureza de cada setor ou as características individuais de cada empresa influencia a abordagem para a internacionalização (BURT, 1995).

As mudanças dos destinos para investimento fornecem indicações sobre os processos de internacionalização. A literatura comenta que parcela dos riscos de se deslocar para o estrangeiro é atenuada com o deslocamento inicial para mercados mais próximos geográfica ou culturalmente. Assim, é esperado o movimento seqüencial de um destino de baixo risco para outro de alto risco (BURT, 1995). 
Um aspecto, ainda, que afeta o desenvolvimento internacional é a regulamentação e a política fiscal existente tanto no país de origem quanto naquele em que se pretende estabelecer operação. Por fim, a atratividade dos mercados e seus consumidores devem ser levados em consideração, bem como a existência de concorrentes locais que já atendam esses mercados e consumidores. Em suma, verifica-se que uma parte dos fatores é do tipo que empurra (push) e a outra parte, do tipo que puxa (pull) o processo de internacionalização. Os fatores que empurram podem ser descritos como aqueles que estimulam a internacionalização. São essencialmente condições que levam os varejistas para novos mercados: estrutura política estável, economia estável, estrutura de varejo pouco desenvolvida, existência de amplo mercado, ambiente socialmente favorável, taxas de câmbio favoráveis, oportunidades de nicho. Os fatores que puxam são caracterizados por condições comerciais não-atrativas, tais como: ausência de estabilidade política, ausência de estabilidade econômica, mercado doméstico em fase de maturidade, saturação do formato de varejo em questão, existência de restrições legais e regulatórias, custos altos para operação (ALEXANDER, 1995).

Segundo Tordjman (1995), diversos fatores, internos e externos, podem explicar o crescimento da internacionalização do varejo dos países europeus. Os fatores externos são:

a) saturação dos mercados domésticos, que tornava mais custoso aumentar a participação de mercado;

b) existência e legislação de expansão restritiva em alguns países, tornando necessária a saída para outros países como alternativa para o crescimento;

c) redução dos custos de transporte, melhoria dos sistemas de informação e abertura de mercados, facilitando a exportação de bens e capital;

d) existência de nichos de mercado de consumidores com preferências similares para determinados bens.

Os fatores internos, por sua vez, são:

a) procura por taxas de crescimento e lucratividade acima daquelas disponíveis no país de origem;

b) diluição dos riscos por meio da operação em diversos países e usando vários formatos de varejo;

c) crença de que possui um conhecimento prático exportável;

d) vontade de aumentar o poder sobre os produtores internacionais em termos de vendas e negociação. 
De acordo com Sternquist (2007), os varejistas se expandem internacionalmente por uma variedade de razões:

a) desejo de ir além do mercado onde atuam, já maduro, com potencial de crescimento pequeno;

b) necessidade de diversificar seus investimentos;

c) expansão dos negócios quando a legislação impõe restrições no local onde já atuam;

d) dificuldade de se proteger contra a cópia de um formato de loja ou negócio (busca de novos locais onde ainda não há o formato);

e) concorrência acirrada no mercado local;

f) recessão na economia doméstica;

g) vantagens de ser o primeiro a se deslocar para o novo mercado.

Além dessas razões, Sternquist (2007) afirma que há uma relação entre o tipo de empresa de varejo e sua vocação para a expansão internacional. Identifica tipos específicos: as empresas chamadas de fortes, que se compõem por aquelas que são geralmente líderes de mercado e detêm vantagens competitivas sobre os concorrentes; as empresas fracas, com dificuldade de manter sua participação de mercado; empresas diferenciadas, únicas em seus segmentos, já que não têm concorrentes; e, por fim, as empresas padronizadas, com alto nível técnico e de treinamento.

McGoldrick (1995) e Alexander e Silva (2002) destacam que pesquisas a respeito das motivações por trás das atividades internacionais identificaram a importância dos fatores que empurram e puxam o processo (push and pull factors). Os fatores que empurram o processo encorajam varejistas a procurar expansão fora de seus mercados domésticos, enquanto os fatores que puxam o processo levam os varejistas para determinados mercados em particular. Esses fatores, como estão representados na Ilustração 17, variam desde a estabilidade do sistema político até nichos de oportunidade disponíveis na estrutura do varejo, e podem ser dispostos em cinco categorias, a saber: políticas, econômicas, sociais, culturais e estruturais do varejo (ALEXANDER, SILVA, 2002). 


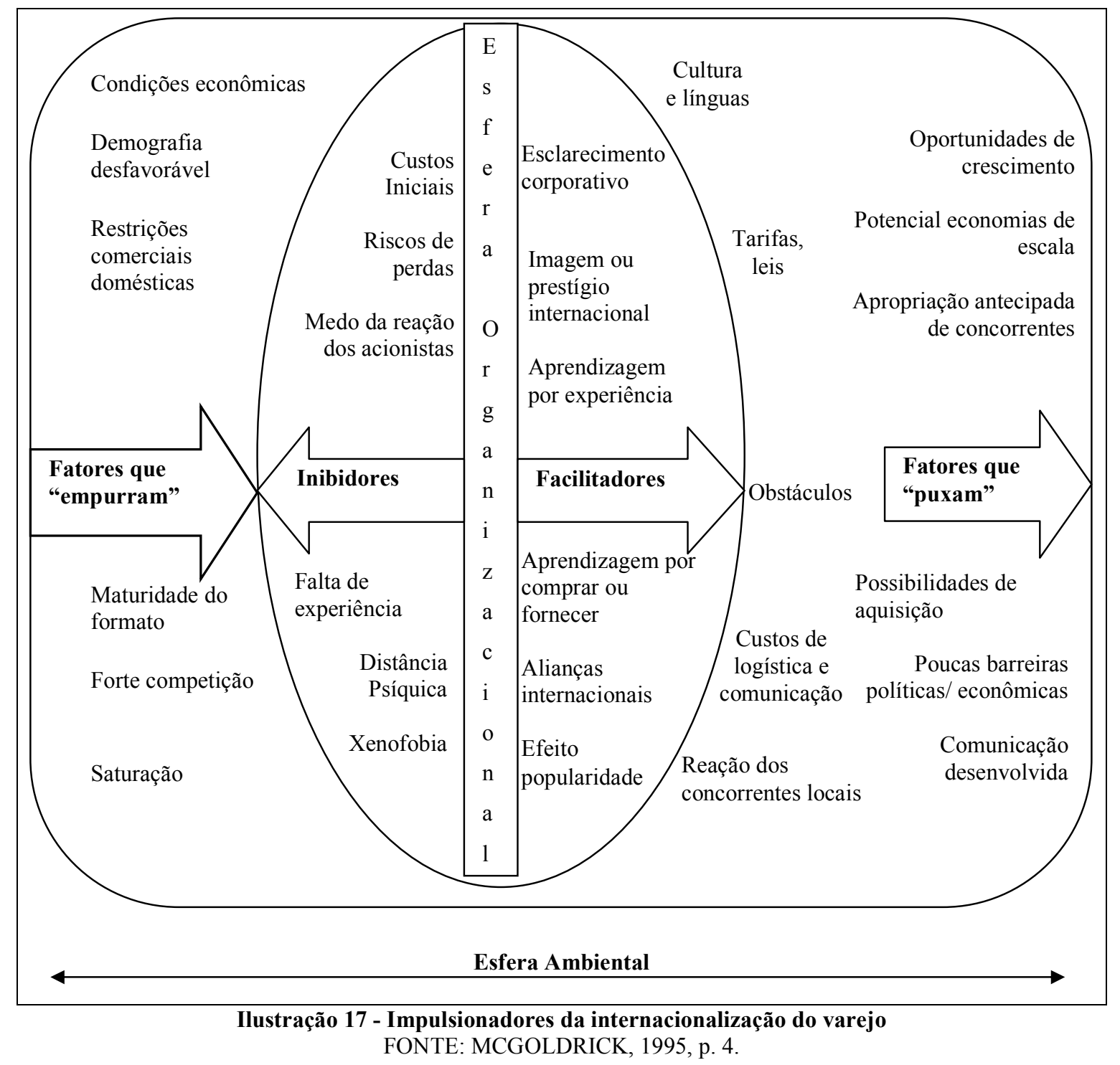

O conceito dos fatores que empurram (push factors) e puxam (pull factors) baseia-se no fato de que os movimentos internacionais dos varejistas foram sempre motivados por dificuldades no mercado doméstico, mais do que por terem sido atraídos para novos mercados. Dados os custos e riscos usualmente envolvidos ao conduzir a experiência inicial em mercados externos, há algumas evidências de que os fatores que empurram são mais significativos nos primeiros estágios da internacionalização (MCGOLDRICK, 1995).

\subsubsection{Estratégias de internacionalização do varejo}

As estratégias de expansão internacional são diferentes para a indústria e para o varejo. Quando a indústria resolve atuar no exterior, geralmente inicia esse processo por meio de 
exportação, em razão de representar um baixo nível de envolvimento, um risco menor. Como o envolvimento com o mercado é restrito, a empresa aprende a conduzir os negócios no mercado onde passa a atuar através de algum distribuidor. O segundo nível de envolvimento acontece por licenciamento de produtos ou da marca da empresa. A operação por licenciamento apresenta o risco de, ao conferir o poder a outra empresa, perder o controle sobre a qualidade do produto e sua distribuição no país estrangeiro. O terceiro nível de envolvimento é por meio de joint-venture, ou seja, a associação com alguma empresa do país de destino, um tipo de operação que propicia conhecimento sobre o novo mercado. O último nível de envolvimento é a abertura de subsidiária própria, em que a indústria tem o controle da produção e da venda. Essa opção envolve uma grande exposição da empresa no novo mercado e promove a oportunidade de ampla aprendizagem sobre ele (STERNQUIST, 2007).

Após identificar o mercado-alvo, as empresas de varejo têm à sua disposição diversas estratégias de entrada. A Ilustração 18 apresenta as alternativas existentes em função do nível de controle e de custos. As empresas devem escolher entre altos custos e amplo controle (é o caso da aquisição) e baixos custos e pouco controle, como acontece nas concessões ou licenciamentos. Os possíveis modos de entrada são o licenciamento, a concessão, franquia, joint-venture, aquisição e o investimento do próprio varejista com instalação de subsidiária. Outra maneira para se internacionalizar sem operar lojas nos mercados externos é estabelecer alianças com varejistas ou atacadistas (MCGOLDRICK, 1995). O licenciamento e a franquia representam as opções de menor envolvimento. A entrada em outro país por licenciamento faz com que uma empresa local (do país) utilize a marca da empresa que está ingressando naquele mercado. Nesse sentido, o varejista perde o controle sobre o negócio, o que não é comum. $\mathrm{O}$ mais usual é a franquia, que se caracteriza por um acordo entre as partes: de um lado, a empresa dona do negócio, o franqueador, cede a marca, o padrão e o treinamento para a operação do negócio pelo parceiro; de outro, esse parceiro ou franqueado passa a representar a empresa franqueadora, pagando pelos custos de instalação e operação do negócio, além de taxas pela utilização da marca e do sistema operacional. Esse tipo de expansão é bastante interessante a curto prazo. Contudo, tendo em vista que esse sistema disponibiliza para o parceiro, o franqueado, as especificidades do negócio, torna-se mais difícil a expansão futura por outros modos (STERNQUIST, 2007).

O segundo nível de envolvimento internacional do varejo é por meio de joint-venture. Esse modo de expansão também implica o compartilhamento de informações entre as empresas. A 
joint-venture pode ser interessante para os varejistas que modificam seus formatos em cada país onde atuam, pois conseguem as informações necessárias para as adaptações nos formatos de negócio através das empresas parceiras (STERNQUIST, 2007).

O terceiro nível de envolvimento internacional do varejo é iniciar as operações por meio de subsidiária própria no novo mercado. Esse é o único modo de entrada que não envolve o compartilhamento de informações (STERNQUIST, 2007). Por outro lado, a empresa não se beneficia do acesso a informações a respeito do novo mercado. Esse modo de entrada em novo local acaba exigindo um planejamento mais detalhado, envolvendo ampla pesquisa sobre cada fator que possa interferir no negócio, como os políticos, econômicos (incluindo cambiais), sociais, culturais, regulatórios (legislativos e jurídicos), ambientais, comerciais (competitivos e estratégicos) e financeiros.

Entretanto, a própria Sternquist (2007) critica essa classificação, apesar de considerá-la em uma primeira análise. Para ela, há efetivamente quatro tipos de internacionalização de varejo, atualmente: por meio de aquisição de outras empresas, por franquia exclusivamente, pela formação de empresa global ou de empresa multinacional. A expansão por meio de aquisição é aquela em que uma empresa faz o investimento e adquire uma outra no país onde quer estabelecer negócio. As empresas que utilizam esse tipo de estratégia estão à procura de retornos sobre o investimento superiores aos que têm domesticamente, investimento seguro ou acesso à experiência do varejista adquirido. A expansão por franquia como único modo de internacionalização acontece geralmente pela utilização de master-franqueado que cuidará de formar a rede de franqueados no local onde atua. Esse formato de expansão geralmente ocorre por iniciativa externa à empresa, quando o investidor que tem interesse em se tornar franqueado procura a empresa e oferece a oportunidade de expansão.

Nesse caso, a expansão não obedece à seqüência de estabelecer operação primeiramente em países culturalmente mais próximos e depois nos mais distantes, e sim em função da rede de relacionamento do master-franqueado. Os outros dois tipos, global e multinacional, não indicam nível de internacionalização. Os varejistas globais são aqueles que se expandem por meio de formato de varejo padronizado (standard). Possuem gestão centralizada, geralmente são integrados verticalmente, focando marcas próprias e propaganda exclusiva, e na maioria das vezes têm lojas de tamanho pequeno a médio. Em função de suas características, buscam locais para expansão onde possam estabelecer operação com poucas adaptações. 


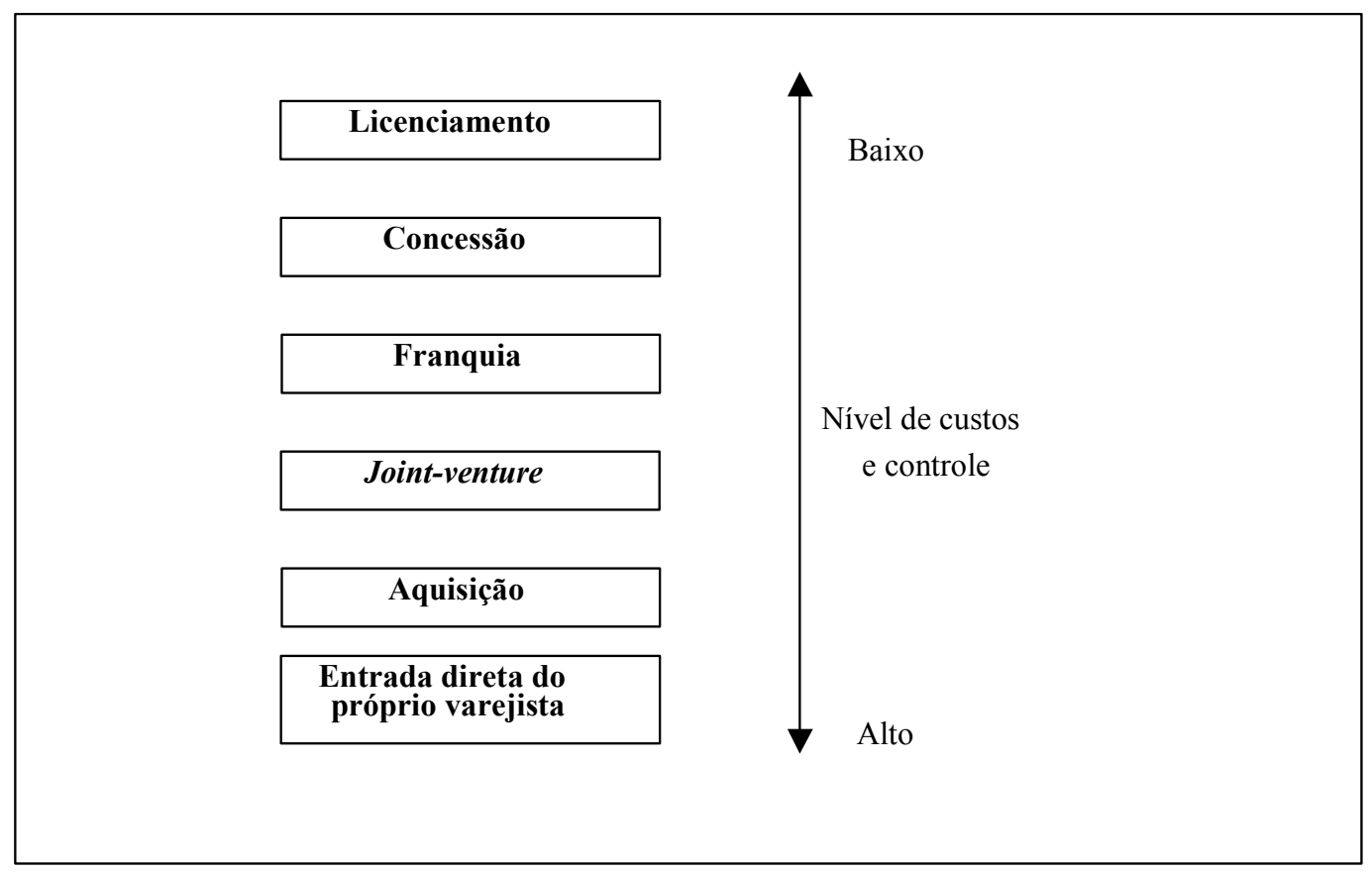

Ilustração 18 - Opções de entrada em novos mercados

FONTE: MCGOLDRICK, 1995, p. 8.

Como esses varejistas são normalmente pequenos, com operação centralizada e padronizada, podem escolher se internacionalizar por meio de investimento próprio (internalizando) ou por meio de franquia (externalizando). Os varejistas multinacionais têm gestão descentralizada, costumam concentrar a expansão geograficamente e adaptam seus produtos em função da cultura do local onde estão atuando. Possuem, usualmente, formatos de loja de grande porte. A expansão por meio de franquia é inviável em virtude do tamanho de suas lojas e da adaptação que fazem em cada local onde atuam. Utilizam alternativamente a internacionalização por meio de licenciamento, que é a opção de baixo custo para esse tipo de varejo. Outra opção é a expansão por meio de investimento próprio. A internacionalização do varejo multinacional acontece após a saturação do mercado onde atua.

\subsubsection{A escolha de mercados internacionais}

A abordagem clássica para a expansão internacional do varejo tem sido analisar os fatores que empurram e que puxam - push and pull factors. Fatores que geralmente empurram os varejistas internacionalmente são a limitação e as restrições de regulamentação do mercado local, que contribuem para sua rápida saturação. Isso leva o varejista que pretende se expandir a considerar a possibilidade de mercados externos. Os fatores que puxam incluem todos os 
atributos que tornam atrativo um país em particular (MCGOLDRICK, 1995; ALEXANDER, SILVA, 2002).

O processo de internacionalização tende a ser analisado como resultante de fatores que empurram em virtude da escola reativa de pensamento. Entre o final dos anos 80 e o início dos 90, a tendência era atribuir à internacionalização do varejo uma postura mais positiva, na qual os mercados internacionais podiam ser oportunidades atrativas. Assim emergiu a escola proativa de pensamento (ALEXANDER, MYERS, 2000). Porém, a importância relativa dos fatores reativos ou proativos é influenciada pelas condições do negócio ao longo do tempo. Contudo, a literatura a respeito da internacionalização do varejo não foca sua atenção exclusivamente no processo de escolha (GRIPSRUD, BENITO, 2005).

Duas teorias sobre negócios internacionais são relevantes para a questão da escolha de mercados. A primeira é o Paradigma Eclético ou Teoria OLI para investimentos diretos, de Dunning, como ponto de partida para o desenvolvimento de um modelo para o varejo. No modelo original as vantagens de localização são analisadas em termos dos fatores que tornam lucrativo localizar uma indústria em determinado país, de onde o produto fabricado é exportado para outros países. Para o varejo, a atratividade de um país para iniciar uma operação relaciona-se com o tamanho e a renda desse mercado, sendo destacados diversos fatores: nível de prosperidade, infra-estrutura, acesso, tamanho do mercado, concorrência e baixo custo de mão-de-obra (VIDA, REARDON, FAIRHURST, 2000; GRIPSRUD, BENITO, 2005).

A segunda teoria baseia-se no enfoque organizacional da firma, no modelo de processo gradual de internacionalização proposto pela Escola de Uppsala. Esse modelo destaca a importância de estudos empíricos e sugere um padrão gradual de internacionalização. Especialmente a indústria é motivada pelos baixos custos de produção, a proximidade de fornecedores e/ou o benefício da aglomeração, e não pelas características da demanda do mercado escolhido. O varejo tradicionalmente orienta-se pela localização dos consumidores, pelo tamanho desse mercado e pelo seu poder aquisitivo (GRIPSRUD, BENITO, 2005).

Sternquist, no artigo "International expansion of U.S. retailers", de 1997, e mais tarde no livro International Retailing, de 2007, propõe uma mesma base para explicar o processo de internacionalização de empresas de varejo americanas que associa fundamentos conceituais: o 
Paradigma Eclético, a Teoria dos Estágios de Expansão (Stages Theory) e a Teoria do Risco (Risk Theory). Porém, na publicação de 2007, acrescenta ao modelo a Teoria Institucional (Institutional Theory), enfatizando a importância dos fatores do macroambiente e do microambiente no processo de internacionalização do varejo e destacando que os estágios de internacionalização para o varejo baseiam-se em risco e conhecimento (STERNQUIST, 2007).

A Teoria dos Estágios (Stages Theory) foca o padrão de internacionalização. De acordo com essa teoria, a empresa se expande primeiramente para países mais similares e, à medida que vai ganhando experiência, desloca-se para países menos similares. O Paradigma Eclético aborda os fatores de propriedade, localização e internalização (STERNQUIST, 1997; 2007).

A Teoria Institucional explica a influência dos fatores do ambiente externo (macroambiente: fatores econômicos, sociais, concorrenciais, tecnológicos e governamentais) e dos fatores internos à empresa (microambiente: concorrentes e experiências passadas) na decisão de se internacionalizar (STERNQUIST, 2007). A Teoria Institucional enfatiza que o ambiente institucional influencia as decisões e o comportamento dos varejistas. $\mathrm{O}$ ambiente institucional se compõe de estruturas regulatórias, leis, regras, valores culturais, normas e hábitos, bem como consumidores, fornecedores e concorrentes. A expansão internacional do varejo consiste, então, no processo de transferência da tecnologia gerencial para outro país (STERNQUIST, 2007).

Há três dimensões no sistema institucional (Teoria Institucional): reguladora, normativa e cognitiva. A dimensão reguladora relaciona-se às questões legais e políticas de um país. A estrutura de leis e políticas de um local tanto pode favorecer o acesso de empresas estrangeiras como criar barreiras para sua entrada ou a ampliação dos negócios naquele país. As restrições ou facilidades acabam por influenciar a escolha do modo de entrada. A dimensão normativa prioriza as normas e a influência da cultura. A distância cultural entre o país de origem de um varejista e o país para onde pretende se expandir afeta a escolha do modo de entrada - a autora chama de distância cultural o conceito a que a Escola de Uppsala dá o nome de distância psíquica. De maneira geral, em caso de grande distância cultural, o varejista pode ter uma percepção de grande risco e, com isso, preferir adotar um modo de entrada de menor controle, como é o caso da franquia e do licenciamento, ou até desistir da expansão para aquele local. À medida que avança em sua internacionalização, ele vai 
aprendendo com o processo, o que afeta os passos a serem adotados em seguida pela empresa. A dimensão cognitiva leva em conta os hábitos e a inércia das organizações: a empresa desenvolve hábitos e inércia em função de suas experiências e estas acabam por obstruir mudanças racionais. Mas as empresas aprendem também em função das experiências de seus concorrentes. As teorias sobre estratégia sugerem que a imitação pode ser uma estratégia adotada em reação à ação da concorrência, assim como a estratégia de segundo a se deslocar (second movers), a fim de aproveitar o fato de a maior parte do risco ter sido absorvida pela primeira empresa a fazer o movimento (STERNQUIST, 2007).

O fundamento conceitual final que serve de base para explicar o processo de internacionalização do varejo é a Teoria do Risco, segundo a qual os varejistas avaliam mercados em função de sua percepção de risco (STERNQUIST, 2007). O modelo incorpora elementos do Paradigma Eclético de Dunning, que foca as variáveis de localização, de propriedade e de internalização como fatores que influenciam a expansão internacional. Nesse sentido, as empresas com grandes vantagens de propriedade escolhem um modelo de expansão global. O modelo global postula que as empresas expandem sua operação por meio de um conceito padronizado de varejo, com gerenciamento centralizado, que é reproduzido em cada novo mercado. A empresa que emprega esse modelo expande-se rapidamente, mas aprende pouco com seu processo de internacionalização. Geralmente, a empresa global de varejo escolhe a franquia como principal modo de entrada em um novo local, por ser uma opção de baixo risco (STERNQUIST, 1997; 2007).

O outro tipo de varejista se desenvolve por meio da expansão multinacional, pois escolhe entrar em novos mercados com vantagem de localização. Esses varejistas empregam um formato descentralizado e adaptam o conceito de varejo de acordo com as diferenças culturais de cada local. Os varejistas multinacionais aprendem sobre a cultura de cada país a fim de gerar as modificações necessárias. A entrada em um novo país se dá por etapas e cria um portfolio de conhecimento. Quando a diferença cultural é grande, um dos modos de entrada preferencialmente adotados é a joint-venture com alguma empresa local, que constitui uma alternativa de expansão de baixo risco para a empresa multinacional de varejo (STERNQUIST, 1997; 2007).

Considerando a Teoria OLI ou Paradigma Eclético de Dunning, a vantagem de propriedade corresponde aos ativos que a empresa utiliza para obter poder de mercado. Os ativos podem 
ser de dois tipos: o ativo com base em vantagens competitivas pode ser a própria marca do produto, do negócio; o ativo com base nas transações resulta da maneira como a empresa realiza suas atividades, tal como economia de escala, volume de compras e preço (STERNQUIST, 1997; 2007).

A vantagem de localização diz respeito ao grau de atratividade de um país estrangeiro para determinado varejista e se relaciona com fatores de empurram (push factors) e fatores que puxam (pull factors). Os fatores que empurram são aqueles que fazem um país menos atrativo, como restrições legais, taxas altas de tributação, saturação de mercado. Os fatores que puxam podem ser a proximidade cultural, o tamanho do mercado, o deslocamento de outros varejistas para o mesmo local, a proximidade geográfica e o baixo custo de mão-deobra ou de área para construção (STERNQUIST, 1997; 2007).

Sternquist (1997; 2007) associa ao modelo o conceito de expansão global e multinacional. Os varejistas globais replicam formatos padronizados, em que uma loja é parecida com a outra. A expansão internacional de varejistas globais se dá por meio de um controle centralizado da operação, pois propicia maior controle e velocidade. Geralmente, são integrados verticalmente, possuem marcas próprias e escolhem a joint-venture como modo de entrada.

Os varejistas multinacionais ajustam o modelo a cada país em função das características locais. O gerenciamento da operação é usualmente descentralizado, o que leva a um processo de expansão mais lento. Concentram a expansão em uma área, primeiramente, para desenvolver conhecimento, e depois se deslocam para novos países ou regiões (STERNQUIST, 1997; 2007).

A autora relaciona no modelo a Teoria dos Estágios de Expansão (Stages Theory), que afirma haver a cada estágio de expansão um aprendizado para o próximo estágio de investimento. Destaca que as empresas de varejo americanas aprendem por meio da expansão no próprio país e depois utilizam esse conhecimento para se deslocar para outros países. Quando a expansão se dá para países mais distantes culturalmente, as empresas geralmente utilizam a joint-venture como modo de entrada, que é uma maneira de formar parceiros locais e desenvolver conhecimento sobre o lugar, sua legislação, as restrições, a concorrência, os hábitos de consumo, a logística, entre outros fatores. Porém, há níveis distintos de aprendizagem. Quando um varejista escolhe o formato de franquia ou licenciamento para sua 
expansão internacional, a aprendizagem é menor, o que redunda em pouca informação que possa auxiliar no deslocamento para outros países. As empresas varejistas também escolhem os destinos de seu deslocamento em função de serem menos saturados do que o local onde atuam (STERNQUIST, 1997; 2007).

Por fim, Sternquist (1997; 2007) agrega ao modelo a Teoria do Risco (Risk Theory), que aborda os riscos ligados à margem ou ao lucro. Essa teoria destaca que cada empresa analisa os riscos de maneira distinta, pois seus gestores têm percepções diferentes do que constitui risco ou vantagem. Assim sendo, a tomada de decisão é inerente ao processo de avaliação de cada indivíduo e sua sensibilidade ao risco. É resultado, também, de fatores como o tamanho da empresa, a experiência operacional, experiência dos gestores em atuação internacional, tolerância dos gestores ao risco e a percepção que têm das vantagens competitivas. Conseqüentemente, o entendimento desses fatores determina se o varejista internalizará ou externalizará a expansão internacional.

O modelo apresentado pela autora tem o objetivo de ajudar a explicar a estratégia de internacionalização do varejo. Pretende ser normativo ao invés de descritivo e se baseia em quatro teorias interconectadas. Os conceitos utilizados dessas teorias são as vantagens de propriedade, as vantagens de localização, as vantagens de internalização, as estratégias globais, as estratégias multinacionais, a expansão em estágios e os riscos (STERNQUIST, 1997; 2007).

O impacto da questão cultural é relevante para o varejo. Evans, Treadgold e Mavondo (2000), e depois Evans e Mavondo (2002), identificaram a distância psíquica como o principal conceito para explicar as variações da expansão geográfica e do desempenho organizacional para o varejo, enquanto Sternquist $(1997 ; 2007)$ menciona a proximidade cultural e geográfica como fator importante para a seleção do mercado no qual se vai entrar. A explicação se relaciona diretamente com o modelo de processo de internacionalização em que o gestor reduz a incerteza percebida e procura identificar custos de entrada avaliando soluções similares às já bem conhecidas nos mercados de origem. Outra explicação é que, ao mesmo tempo em que a demanda é um fator relevante por si só para o varejista, o conhecimento do mercado externo é indispensável para adequar os conceitos do negócio ao mercado em questão. Dessa maneira, o negócio pode ser transferido para um novo mercado, mas depende das similaridades entre este e os outros em que o negócio já se desenvolveu anteriormente. 
Apesar de a internacionalização parecer altamente arriscada nos estágios iniciais, nem a percepção do gestor nem a própria transferência do negócio apresentam um processo constante; mudam em função da aprendizagem gradual advinda da experiência vivenciada na entrada em outros mercados, ou seja, o conhecimento se acumula na firma (STERNQUIST, 1997; 2007; ALEXANDER, MYERS, 2000; GRIPSRUD, BENITO, 2005; PALMER, QUINN, 2005; MELLO, MIRANDA, VILELA, s.d.).

\subsection{Conclusão da fundamentação teórica}

Apesar dos esforços acadêmicos recentes para estender as bases teóricas além da indústria e examinar o envolvimento internacional das firmas de serviços, a literatura ainda apresenta lacunas quanto à sistematização de uma estrutura teórica que possa dar suporte às pesquisas a respeito da internacionalização do varejo. Os trabalhos que têm sido feitos envolvendo as empresas de varejo focalizam principalmente a abordagem operacional, a dispersão geográfica, os custos operacionais e de controle ou as questões estratégicas, ou seja, ainda um pequeno espectro das temáticas referentes ao setor. O resultado é a disponibilização de uma pequena quantidade de informações desejáveis para o desenvolvimento e crescimento das firmas de varejo.

Comparando-se as teorias, abordagens e enfoques empregados em seu sentido mais amplo, ou seja, para as empresas de modo geral, com aquelas utilizadas pelos autores pesquisados para explicar o processo de internacionalização de empresas de varejo, percebe-se que apenas uma parte dessas estruturas teóricas foi aplicada para os estudos sobre varejo. A Ilustração 19 mostra em cinza as teorias, abordagens ou enfoques que são comuns para os dois casos. Em razão de os estudos analisados sobre internacionalização de varejo empregarem apenas uma parcela das estruturas teóricas sobre internacionalização, esta tese se apropria das teorias empregadas para internacionalização no seu sentido mais amplo (Ilustração 19).

Os estudos focalizam os fatores que puxam e empurram a expansão internacional das empresas de varejo (razões que levam à internacionalização), as estratégias associadas aos modos de entrada nos novos locais e a modificação no tipo de operação em função de uma crescente ampliação de conhecimento sobre as características desse local, ou seja, o processo de aprendizagem ao longo do tempo. 


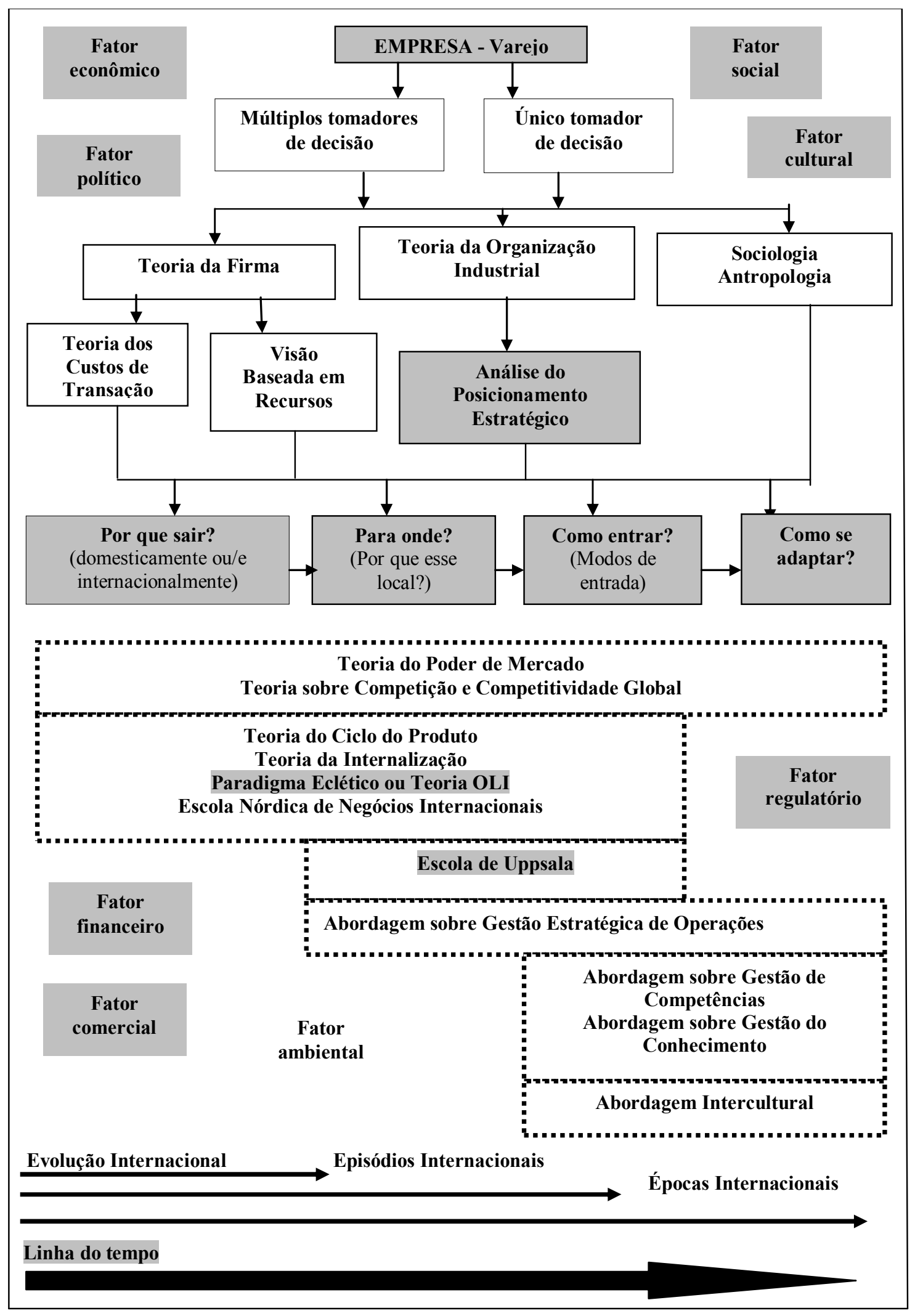

Ilustração 19 - Varejo e as teorias sobre internacionalização 
Os fatores que interferem no processo de internacionalização de varejo destacados pelos autores pesquisados são de caráter econômico, político, social, cultural, financeiro, comercial e regulatório, com exceção do fator ambiental, que não é mencionado e que é abordado em estudos sobre internacionalização de outros tipos de negócio.

As teorias evidenciadas nos trabalhos pesquisados e comuns àqueles que analisam empresas de varejo e aos que avaliam as empresas de outros setores são o Paradigma Eclético, a Escola de Uppsala e o Posicionamento Estratégico. Empregam-se também como alicerce teórico para os estudos de internacionalização de varejo a Teoria dos Estágios de Expansão (Stages Theory), Teoria do Risco (Risk Theory) e Teoria Institucional (Institutional Theory). A Teoria dos Estágios de Expansão relaciona-se ao modelo teórico proposto pela Escola de Uppsala na medida em que enfatiza que o processo de internacionalização se dá de maneira gradual. $\mathrm{Ou}$ seja, relaciona-se ao conhecimento que a empresa tem do país onde pretende estabelecer negócios. Esse conhecimento é ampliado de maneira gradual, o que acaba por definir o grau de comprometimento da empresa com o local e o modo de entrada escolhido (ANDERSEN, 1993; BELL, 1995; BARKEMA, BELL, PENNINGS, 1996; OVIATT, MCDUGALL, 2005). Já a Teoria do Risco tem sua origem nas teorias financeiras que avaliam os fatores que compõem os riscos inerentes ao processo de expansão internacional (CAVUSGIL, 1984; HILL, HWANG, KIM, 1990; EROGLU, 1992; KWOK, REEB, 2000). As teorias financeiras, por sua vez, originam-se das teorias econômicas. Por fim, a Teoria Institucional vincula-se à Teoria da Firma (SCOTT, CHRISTENSEN, 1995).

Há muito que fazer. Por um lado, o conceito de internacionalização e sua fundamentação teórica precisam ser ampliados a fim de contemplar a diversidade dos negócios internacionais, bem como as novas condições que o ambiente impõe. Por outro, as pesquisas empíricas sobre a internacionalização de varejo precisam ganhar a atenção dos pesquisadores para se construir um conhecimento vital para o futuro dessas empresas.

Em seqüência o capítulo 3 apresenta a metodologia de pesquisa empregada para o desenvolvimento da investigação empírica, seguida da análise dos dados no capítulo 4 e das conclusões, limitações do estudo e sugestões para pesquisas futuras no capítulo 5. 


\section{METODOLOGIA DE PESQUISA}

\subsection{Introdução}

O presente estudo tem por finalidade investigar a relação entre as teorias sobre internacionalização de empresas e o processo de expansão para países estrangeiros de dez empresas de varejo brasileiras: identificar o que leva uma empresa a se deslocar para outros países; para onde se desloca (por que escolhe determinados locais em detrimento de outros); quais são os modos de entrada selecionados e como as empresas se adaptam aos novos locais. A Análise de Conteúdo e a Análise de Correspondência constituem os procedimentos metodológicos adotados para responder ao problema de pesquisa desta tese.

Para tanto, é utilizada bibliografia sobre as teorias de internacionalização de empresas e dados primários oriundos de entrevistas em profundidade com gestor ligado à internacionalização de cada uma das dez empresas de varejo brasileiras pesquisadas: Arezzo, Carmen Steffens, Chilli Beans, Lilica Ripilica (Marisol), Morana, Mundo Verde, Nobel, O Boticário, Spoleto e Victor Hugo.

\subsection{Fundamentos teóricos da Análise de Conteúdo}

Segundo Bardin (2004), a Análise de Conteúdo é um método composto de um conjunto de técnicas de análise de comunicações, que possibilita compreender a mensagem para além de seus significados imediatos. Possui duas funções que coexistem: uma heurística, quando enriquece a tentativa exploratória e aumenta a propensão à descoberta, e outra, a administração da prova, quando serve para confirmar uma questão. Dessa forma, auxilia a superação da incerteza e o enriquecimento da compreensão da mensagem.

Para Weber (1990), a Análise de Conteúdo (Content Analysis) é um método de pesquisa que usa um conjunto de procedimentos para fazer inferências válidas a partir de um texto, as quais recaem sobre os emissores, a mensagem em si ou os receptores: “Análise de conteúdo é um método de pesquisa que utiliza um conjunto de procedimentos para fazer inferências válidas a 
partir de texto. Essas inferências são sobre o remetente (s) da mensagem, a mensagem em si, ou o remetente da mensagem"1 (WEBER, 1990, p. 9).

Riffe, Lacy e Fico (1998) definem a Análise de Conteúdo segundo uma perspectiva quantitativa. Para esses autores, a Análise de Conteúdo consiste no exame sistemático e replicável dos símbolos da comunicação, aos quais foram atribuídos valores numéricos de acordo com as regras válidas de medição e a análise de relacionamento entre esses valores. São empregados métodos estatísticos, a fim de descrever a comunicação, desenhar inferências a respeito do significado ou da comunicação em seu contexto, tanto de produção, quanto de consumo:

A análise de conteúdo quantitativa é o exame sistemático e replicável dos símbolos da comunicação, aos quais foram atribuídos valores numéricos de acordo com regras válidas de medição, bem como a análise das relações que envolvem esses valores usando métodos estatísticos, a fim de descrever a comunicação, fazer inferências sobre o seu significado ou inferir, a partir da comunicação, o seu contexto tanto de produção quanto de consumo. ${ }^{2}$ (RIFFE, LACY, FICO, 1998, p. 20).

Neuendorf (2002) define a Análise de Conteúdo como a análise quantitativa sistemática, objetiva, das características das mensagens. Inclui o exame cuidadoso das interações humanas, a análise do caráter realista dos comerciais de televisão, filmes e novelas, além da investigação por meio computacional do uso da palavra em discursos políticos, entre outras aplicações:

Análise de conteúdo pode ser brevemente definida como a análise quantitativa sistemática e objetiva, das características da mensagem. Inclui a análise cuidadosa das interações humanas, a análise do caráter das imagens dos comerciais na TV, filmes e novelas; a investigação por meio computacional sobre o uso da palavra em novos lançamentos e discursos políticos; e muito mais. ${ }^{3}$ (NEUENDORF, 2002, p. 1).

Para Krippendorff (2004), a Análise de Conteúdo pode ser definida como a técnica de pesquisa empregada a fim de obter inferências válidas e replicáveis sobre textos (ou outra

\footnotetext{
1 "Content Analysis is a research method that uses a set of procedures to make valid inferences from text. These inferences are about the sender(s) of the message, the message itself, or the audience of the message."

2 "Quantitative content analysis is the systematic and replicable examination of symbols of communication, which have been assigned numeric values according to valid measurement rules, and the analysis of relationships involving those values using statistical methods, in order to describe the communication, draw inferences about its meaning, or infer from the communication to its context, both of production and consumption."

3 "Content analysis may be briefly defined as the systematic, objetive, quantitative analysis of message characteristics. It includes the careful examination of human interactions; the analysis of character portrayals in $T V$ commercials, films, and novels; the computer-driven investigation of word usage in new releases and political speeches; and so much more."
} 
questão significativa) nos contextos de seu uso: "Análise de conteúdo é uma técnica de investigação para fazer inferências replicáveis e válidas a partir de textos (ou outro assunto significativo) para os contextos da sua utilização". ${ }^{4}$ (KRIPPENDORFF, 2004, p. 18).

Bardin (2004) destaca que a aplicação da Análise de Conteúdo é extremamente vasta, podendo ser empregada em qualquer comunicação, qualquer transporte de significações de um emissor para um receptor. Pode ser uma análise dos significados, como, por exemplo, a análise temática, e, também, dos significantes, como, por exemplo, a análise lexical. É indicada para a investigação das causas a partir dos efeitos, porém o inverso não acontece: não deve ser empregada para prever efeitos a partir de causas.

Um conjunto de técnicas de análise das comunicações visando obter, por procedimentos sistemáticos e objetivos de descrição do conteúdo das mensagens, indicadores (quantitativos ou não) que permitam a inferência de conhecimentos relativos às condições de produção/recepção (variáveis inferidas) destas mensagens. (BARDIN, 2004, p. 37).

Segundo Weber (1990), a Análise de Conteúdo apresenta diversas vantagens quando comparada com outras fontes de geração de dados e técnicas de análise, já que a comunicação é o aspecto central da interação social. Os procedimentos da Análise de Conteúdo operam diretamente no texto ou nas transcrições da comunicação humana, empregando neles operações quantitativas e qualitativas. Dessa maneira, combina modos de análise considerados antitéticos. Podem-se extrair indicadores culturais por meio da análise de documentos produzidos ao longo do tempo, que constituem fontes confiáveis de dados. Apesar de os dados poderem ser obtidos por outras fontes, os indicadores culturais podem ser empregados para acessar os relacionamentos quantitativos entre mudanças econômicas, sociais, políticas e culturais. O autor chama a atenção para as possíveis áreas de aplicação da análise de conteúdo (WEBER, 1990): problemas com intersecção entre cultura, estrutura social e interação social; geração de variáveis dependentes em questões experimentais; estudo de pequenos grupos como microcosmos da sociedade. O Quadro 1 mostra os possíveis domínios da aplicação da Análise de Conteúdo (BARDIN, 2004, p. 30).

\footnotetext{
4 "Content analysis is a research technique for making replicable and valid inferences from texts (or other meaningful matter) to the contexts of their use."
} 


\subsubsection{Organização da análise}

A Análise de Conteúdo organiza-se cronologicamente em três fases distintas (BARDIN, 2004):

a) pré-análise;

b) exploração do material;

c) tratamento dos dados, inferências e sua interpretação.

Quadro 1 - Domínios possíveis da aplicação da Análise de Conteúdo

\begin{tabular}{|c|c|c|c|c|}
\hline Código e suporte & $\begin{array}{l}\text { Uma pessoa } \\
\text { Monólogo }\end{array}$ & $\begin{array}{c}\text { Comunicação } \\
\text { dual } \\
\text { Diálogo }\end{array}$ & Grupo restrito & $\begin{array}{c}\text { Comunicação de } \\
\text { massa }\end{array}$ \\
\hline $\begin{array}{l}\text { Lingüístico } \\
\text { Escrito }\end{array}$ & $\begin{array}{l}\text { Agendas, maus } \\
\text { pensamentos, } \\
\text { diários íntimos }\end{array}$ & $\begin{array}{l}\text { Cartas, respostas a } \\
\text { questionários, a } \\
\text { testes projetivos, } \\
\text { trabalhos escolares }\end{array}$ & $\begin{array}{l}\text { Ordens de serviço } \\
\text { numa empresa, } \\
\text { todas as } \\
\text { comunicações } \\
\text { escritas traçadas de } \\
\text { um grupo }\end{array}$ & $\begin{array}{l}\text { Jornais, livros, } \\
\text { anúncios } \\
\text { publicitários, } \\
\text { cartazes, literatura, } \\
\text { textos jurídicos, } \\
\text { panfletos }\end{array}$ \\
\hline $\begin{array}{c}\text { Lingüístico } \\
\text { Oral }\end{array}$ & $\begin{array}{l}\text { Delírio do doente } \\
\text { mental, sonhos }\end{array}$ & $\begin{array}{c}\text { Entrevistas e } \\
\text { conversas de } \\
\text { qualquer espécie }\end{array}$ & $\begin{array}{c}\text { Discussões, } \\
\text { entrevistas, } \\
\text { conversas de grupo } \\
\text { de qualquer } \\
\text { natureza }\end{array}$ & $\begin{array}{c}\text { Exposições, } \\
\text { discursos, rádio, } \\
\text { televisão }\end{array}$ \\
\hline $\begin{array}{c}\text { Icônico } \\
\text { (sinais, grafismos, } \\
\text { imagens, } \\
\text { fotografias, filmes } \\
\text { etc.) }\end{array}$ & $\begin{array}{c}\text { Caretas mais ou } \\
\text { menos } \\
\text { automáticas, } \\
\text { sonhos }\end{array}$ & $\begin{array}{c}\text { Respostas aos } \\
\text { testes projetivos, } \\
\text { comunicação entre } \\
\text { duas pessoas } \\
\text { através da imagem }\end{array}$ & $\begin{array}{c}\text { Toda a } \\
\text { comunicação } \\
\text { icônica num } \\
\text { pequeno grupo }\end{array}$ & $\begin{array}{l}\text { Sinais de trânsito, } \\
\text { cinema, } \\
\text { publicidade, } \\
\text { pintura, cartazes, } \\
\text { televisão }\end{array}$ \\
\hline $\begin{array}{l}\text { Outros códigos } \\
\text { semióticos } \\
\text { (tudo o que, não } \\
\text { sendo lingüístico, } \\
\text { pode ser portador } \\
\text { de significados, } \\
\text { como música, } \\
\text { código olfativo, } \\
\text { objetos diversos, } \\
\text { comportamentos, } \\
\text { espaço, tempo, } \\
\text { sinais patológicos } \\
\text { etc.) }\end{array}$ & $\begin{array}{l}\text { Manifestações } \\
\text { histéricas da } \\
\text { doença mental, } \\
\text { posturas, gestos, } \\
\text { tiques, dança, } \\
\text { coleções de objetos }\end{array}$ & $\begin{array}{l}\text { Comunicação não- } \\
\text { verbal com destino } \\
\text { a outrem (postura, } \\
\text { gestos, distância } \\
\text { espacial, sinais } \\
\text { olfativos, } \\
\text { manifestações } \\
\text { emocionais, } \\
\text { objetos } \\
\text { quotidianos, } \\
\text { vestuário) } \\
\text { comportamentos } \\
\text { diversos, tais como } \\
\text { os ritos e as regras } \\
\text { de cortesia }\end{array}$ & $\begin{array}{l}\text { Comunicação não- } \\
\text { verbal com destino } \\
\text { a outrem (postura, } \\
\text { gestos, distância } \\
\text { espacial, sinais } \\
\text { olfativos, } \\
\text { manifestações } \\
\text { emocionais, } \\
\text { objetos } \\
\text { quotidianos, } \\
\text { vestuário) } \\
\text { comportamentos } \\
\text { diversos, tais como } \\
\text { os ritos e as regras } \\
\text { de cortesia }\end{array}$ & $\begin{array}{c}\text { Meio físico e } \\
\text { simbólico: } \\
\text { sinalização urbana, } \\
\text { monumentos, arte; } \\
\text { mitos, estereótipos, } \\
\text { instituições, } \\
\text { elementos de } \\
\text { cultura }\end{array}$ \\
\hline
\end{tabular}

FONTE: BARDIN, 2004, p. 30.

A fase de pré-análise corresponde à formulação do plano de análise. Compreende a sistematização das idéias iniciais a fim de delimitar o esquema de operações sucessivas. Possui três etapas: a escolha dos documentos a serem analisados, a formulação das hipóteses e dos objetivos que se pretende atingir, e a definição dos indicadores que guiarão a interpretação. Cabe à fase de exploração do material a análise dos documentos, propriamente dita, que pode se dar manualmente ou por intermédio de programas de computador. A fase seguinte é a de tratamento estatístico dos dados por meio de técnicas multivariadas. 


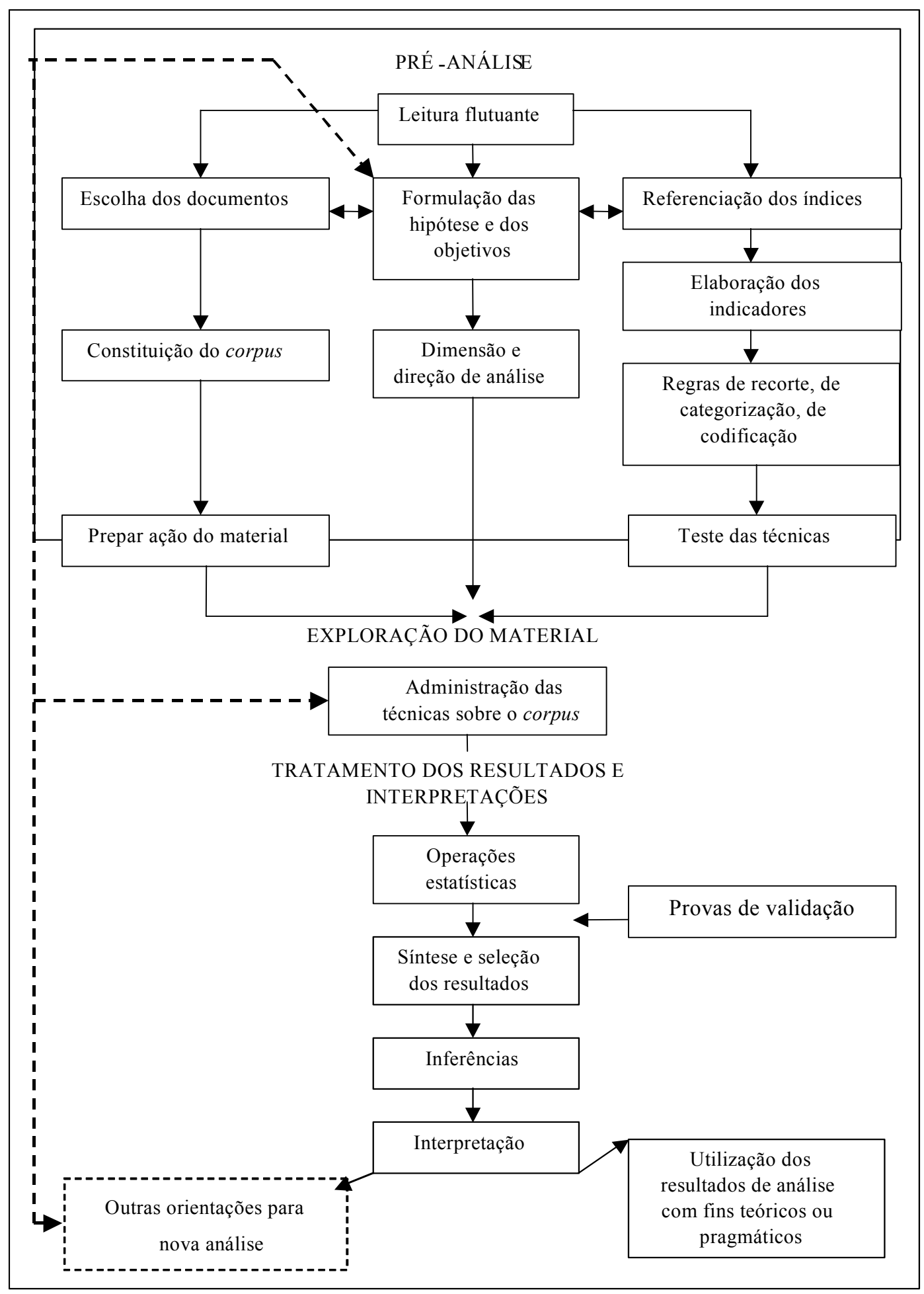

Ilustração 20 - Desenvolvimento de uma análise FONTE: BARDIN, 2004, p. 96. 
A partir da análise dos resultados do tratamento estatístico se obtêm as inferências e interpretações (BARDIN, 2004). A Ilustração 20 demonstra esse processo.

\subsubsection{Codificação}

A segunda fase da Análise de Conteúdo compreende a codificação do material. Corresponde à transformação de dados brutos em representações de conteúdo, utilizando-se regras precisas (BARDIN, 2004). A organização da codificação do material compõe-se de três etapas (nos casos de análise quantitativa e categorial):
a) recorte ou escolha das unidades de análise;
b) enumeração ou escolha das regras de contagem;
c) classificação e agregação ou escolha das categorias.

O critério para recorte é sempre de ordem semântica ou por correspondência com unidades formais, como palavra associada ao tema ou frase associada à unidade significante. As unidades mais usadas são a palavra e o tema. A análise temática consiste em identificar os núcleos de sentido que compõem a comunicação e que apresentam freqüência de aparição significativa para o atendimento dos objetivos. O tema é comumente empregado para os casos de resposta a questões abertas, entrevistas individuais ou em grupo e também para estudar motivações de opiniões, de atitudes, de valores, crenças, tendências, entre outras.

Devem-se identificar os temas-eixo em redor dos quais o discurso se organiza. Pode-se também analisar o personagem, ou seja, o ator da unidade de registro. Além disso, é possível combinar essa análise com outros tipos de unidade, como o acontecimento e/ou o documento - livros, artigos, filmes (BARDIN, 2004).

$\mathrm{Na}$ etapa da definição da regra de enumeração, determina-se o conjunto de textos e cria-se a classificação para contar a presença e a ausência de elementos, a fỉm de calcular a freqüência desses elementos. Outra medida é a determinação da freqüência ponderada ou, ainda, o cálculo da intensidade de ocorrência de um elemento. A intensidade corresponde à medição das variações semânticas ou formais dentro de uma classe de elementos (BARDIN, 2004). 
A Análise de Conteúdo propicia uma abordagem tanto quantitativa - com a freqüência de aparição de elementos - como qualitativa, com a presença de índices - temas, palavras, personagens (BARDIN, 2004).

\subsubsection{Categorização e inferência}

As categorias são rubricas ou classes que agrupam um conjunto de elementos que possuem características comuns. A formação de categorias obedece ao critério semântico (temas), sintático (verbos, adjetivos), lexical (classificação segundo seu sentido, considerando-se os sinônimos ou palavras com sentido próximo) ou expressivo (como, por exemplo, perturbações da linguagem). A categorização compõe-se pela classificação dos elementos constitutivos de um material, procurando agrupar os elementos similares numa mesma categoria e separar os elementos distintos em categorias diferentes. Ela comporta duas etapas, sendo a primeira de isolamento dos elementos (inventário) e a segunda de distribuição desses elementos com a finalidade de criar uma organização (classificação) (BARDIN, 2004).

O processo de categorização deve obedecer aos seguintes critérios (BARDIN, 2004):

a) exclusão mútua: cada elemento não pode existir em mais de uma divisão;

b) homogeneidade: um mesmo conjunto categorial só pode funcionar com um registro e uma dimensão de análise;

c) pertinência: uma categoria é considerada pertinente quando se adapta ao material de análise e pertence ao quadro teórico definido. O sistema de categorias deve refletir as intenções da investigação, as questões de análise;

d) objetividade e fidelidade: devem-se definir claramente as variáveis e os índices que determinam a entrada de um elemento em uma categoria;

e) produtividade: um conjunto de categorias é produtivo quando propicia resultados significativos em termos dos índices que fornece, de novas hipóteses e dados precisos.

\subsubsection{Técnicas de Análise de Conteúdo}

O método de Análise de Conteúdo compõe-se de seis técnicas (BARDIN, 2004):

a) Análise Categorial: funciona por operações de divisão do texto em unidades, que constituem categorias segundo reagrupamentos analógicos. É útil para a investigação e análise de temas, além de ser rápida e eficaz em discursos diretos e simples; 
b) Análise de Avaliação: sua finalidade é medir as atitudes do locutor em relação aos objetos dos quais fala. Essa análise fundamenta-se na linguagem representacional, ou seja, considera que a linguagem representa e reflete diretamente aquele que a emprega;

c) Análise de Enunciação: analisa a comunicação em termos de seu processo, e não como um dado. Desvia-se das estruturas e dos elementos formais. É empregada principalmente em discursos resultantes de entrevistas não-estruturadas;

d) Análise da Expressão: os indicadores desse tipo de análise não são de ordem semântica (conteúdo plano dos significados), mas de ordem formal, ou seja, voltam-se para o plano dos significantes e a sua organização;

e) Análise das Relações: analisa não apenas a freqüência de aparição dos elementos de um texto, mas também as relações que esses elementos mantêm entre si. Pode ser dividida em dois planos: análise de contingências (contingency analysis) e análise estrutural. A primeira procura extrair as relações entre os elementos da mensagem, ou seja, assimilar presenças simultâneas de dois ou mais elementos em uma unidade de contexto (fragmento de mensagem). A segunda dedica-se aos princípios de organização subjacentes, aos sistemas de relações, às regras de encadeamento, de associação, de exclusão, ou seja, a todas as relações que estruturam os elementos - signos ou significações - de maneira independente desses elementos.

f) Análise do Discurso: tem por objetivo a substituição da Análise de Conteúdo por outros meios, mas com a mesma finalidade. Analisa um discurso, focando as condições de sua produção e o seu sistema lingüístico. Leva em conta que o discurso é determinado não apenas pelo referente, mas também pela posição do emissor nas relações de força e também sua relação com o receptor.

\subsubsection{Técnica de Análise de Correspondência}

Um dos primeiros trabalhos sobre a Análise de Correspondência foi desenvolvido por JeanPaul Benzecri, em 1969 (apud WELLER, ROMNEY, 1990; BLASIUS, GREENACRE, 1998; CLAUSEN, 1998). Trata-se de uma técnica de interdependência que propicia a redução dimensional da classificação de objetos em um conjunto de atributos. É uma das técnicas de escalonamento multidimensional, que cumprem a finalidade de ajudar o pesquisador a identificar dimensões-chave inerentes a avaliações feitas por respondentes em relação a objetos, que podem ser empresas, produtos, idéias ou outros itens relacionados à percepção. Baseando-se na comparação de objetos, as técnicas de escalonamento multidimensional 
podem inferir dimensões subjacentes de vários julgamentos de similaridade ou preferência fornecidas por respondentes. Auxiliam a definição de (HAIR, ANDERSON, TATHAM, BLACK, 2005):

a) dimensões utilizadas pelos respondentes quando avaliam objetos;

b) quantidade de dimensões usadas pelos respondentes em uma determinada situação;

c) importância relativa de cada dimensão;

d) maneira como os objetos estão relacionados em termos de percepção.

O objetivo das técnicas de escalonamento multidimensional é transformar julgamentos de respondentes quanto a similaridades ou preferências em distâncias representadas em espaço multidimensional. O resultado é uma representação gráfica em forma de mapa perceptual ou mapa espacial que registra a posição relativa de todos os objetos (HAIR, ANDERSON, TATHAM, BLACK, 1998; 2005).

A análise de correspondência compõe-se por procedimento matemático que relaciona e forma uma matriz bidimensional retangular com números positivos. O resultado é um mapa que mostra atributos de linhas e colunas representados por pontos em um espaço com dois ou mais eixos. Apesar de o mapa perceptual poder ser apresentado em duas ou mais dimensões, usualmente é representado em dois eixos para facilitar a visualização e análise dos resultados (WELLER, ROMNEY， 1990; REMENYI，1992; BLASIUS， GREENACRE，1998; CLAUSEN, 1998).

Esta técnica possibilita a formação de mapas perceptuais de objetos relacionados aos atributos e viabiliza a quantificação de dados qualitativos encontrados em variáveis dominantes. Pode acomodar dados não-métricos e relações não-lineares em uma representação multivariada de interdependência. É uma técnica composicional, pois o mapa perceptual baseia-se na associação entre objetos e um conjunto de características descritivas ou atributos especificados pelo pesquisador. Destina-se a retratar a correspondência de categorias de variáveis, principalmente variáveis medidas em escalas nominais (HAIR, ANDERSON, TATHAM, BLACK, 1998; 2005).

A Análise de Correspondência usa o conceito estatístico qui-quadrado para padronizar a comparação de freqüências reais de células com freqüências esperadas de células. A partir do cálculo do qui-quadrado é criado o mapa perceptual. Os valores de similaridade, ou seja, os 
qui-quadrados com sinal, fornecem a medida padronizada de associação. A partir dessas medidas, a Análise de Correspondência cria uma medida de distância métrica e gera dimensões ortogonais sobre as quais as categorias são lançadas para explicar melhor a intensidade de associação representada pelas distâncias qui-quadrado. A Análise de Correspondência apresenta diversas vantagens ao pesquisador (HAIR, ANDERSON, TATHAM, BLACK, 2005):

a) a simples tabulação cruzada de múltiplas variáveis categóricas pode ser representada em um espaço perceptual, o que permite analisar as respostas existentes ou reuni-las em nível categórico ou nominal;

b) retrata relações entre categorias de linhas e colunas, o que forma um grupo de atributos muito semelhante a um fator de análise de componentes principais;

c) fornece uma visão conjunta de categorias das linhas e colunas na mesma dimensão.

Contudo, apresenta desvantagens e limitações (HAIR, ANDERSON, TATHAM, BLACK, 2005):

a) a técnica é descritiva e não é adequada ao teste de hipóteses;

b) caso o objetivo da pesquisa seja a relação quantitativa de categorias, recomendam-se os métodos como o modelo log-linear;

c) é mais indicada para análise exploratória de dados, ou seja, não proporciona a definição de conclusões;

d) exige equilíbrio, por parte do pesquisador, para a realização de interpretação (inferências) e cautela na representação dos dados;

e) a técnica é muito sensível a dados atípicos.

\subsection{Procedimentos metodológicos aplicados ao estudo}

Esta tese tem a finalidade de investigar a internacionalização de dez empresas brasileiras de varejo: Arezzo, Carmen Steffens, Chilli Beans, Lilica Ripilica (Marisol), Morana, Mundo Verde, Nobel, O Boticário, Spoleto e Victor Hugo. Definiu-se o roteiro para entrevista em profundidade a fim de coletar os dados primários. Esse roteiro compõe-se de perguntas abertas, visando a descortinar o que leva uma empresa a se deslocar para outros países; para onde se desloca (por que escolhe determinados locais em detrimento de outros); quais são os modos de entrada selecionados e como as empresas se adaptam aos novos locais (Apêndice 
1). $O$ roteiro da entrevista possui dois blocos distintos. $O$ Bloco I refere-se à caracterização do entrevistado. O Bloco II aborda o processo de internacionalização da empresa.

A amostra deste estudo é não-probabilística e de conveniência. Sendo assim, foram escolhidos os membros mais acessíveis da população. No caso deste estudo, os membros são os gestores de empresas brasileiras de varejo que internacionalizaram suas operações. Segundo Riffe, Lacy e Fico (1998), a amostra de conveniência apresenta limitações, principalmente quando se pretende inferir sobre grandes populações, porém pode ser aplicada em três condições: quando o material é difícil de se obter; quando há limitação de recursos financeiros e de tempo, o que acaba inviabilizando a utilização de amostra aleatória de uma população; quando o pesquisador está investigando uma área pouco explorada em outros estudos. A escolha de uma amostra de conveniência para este estudo ancora-se em duas das condições apresentadas pelos autores: dificuldade de conseguir contato com os gestores das empresas e existência restrita de informações sobre as empresas de varejo brasileiras com operação no exterior.

As entrevistas em profundidade foram feitas com um gestor de cada empresa. $\mathrm{O}$ critério para a escolha de cada entrevistado foi seu conhecimento ou sua participação nas atividades de internacionalização da empresa. Cada entrevista foi gravada, transcrita na íntegra e depois examinada por meio do método de Análise de Conteúdo, com o auxílio de lingüista.

\subsubsection{Etapas da análise dos dados}

A análise dos dados abrangeu duas etapas - a primeira, relacionada à execução da Análise de Conteúdo das entrevistas; a segunda, à Análise de Correspondência. A etapa de Análise de Conteúdo envolveu cinco fases. A primeira fase compôs-se pela análise do texto resultante da transcrição de cada uma das dez entrevistas. A segunda fase, pela categorização dos trechos selecionados. A terceira fase constituiu-se da definição de proposições para cada uma das 11 teorias sobre internacionalização de empresas que foram selecionadas como objeto desta tese, dando origem a 11 categorias. A quarta fase compreendeu a classificação dos trechos, agrupando-os segundo essas categorias. A última fase envolveu o cálculo das freqüências absolutas a partir dos trechos sintetizados por meio da Análise de Conteúdo de cada uma das entrevistas. As etapas que envolveram a análise dos dados está sistematizada na Ilustração 21. 
A Análise de Conteúdo compreendeu a preparação das entrevistas transcritas a partir das entrevistas gravadas. A preparação foi feita por lingüista para garantir neutralidade no procedimento - ausência de envolvimento com o entrevistado e conhecimento teórico sobre o tema da tese. Nessa preparação, os textos foram sintetizados para eliminar todos os trechos que não remetiam à temática de internacionalização de empresas. Foram excluídos os trechos que representavam:

a) caracterização da empresa;

b) imagem da marca;

c) assuntos ligados às vaidades do entrevistado;

d) termos de função fática (elementos empregados para manter a conversação);

e) redundâncias;

f) demonstrações de conhecimento sobre o tema da entrevista;

g) atividade ou comportamento de outras empresas que não estavam em estudo no momento;

h) ufanismo;

i) caracterização do Brasil;

j) explicações (apostos);

1) metáforas.

O resultado foi a obtenção de um conjunto de trechos relacionados ao processo de internacionalização de cada uma das dez empresas. Esses trechos foram tematizados. Os temas para classificação dos trechos emergiram da própria análise lingüística. Através dessa tematização foi possível identificar a similaridade entre os temas propostos por lingüista e os temas sugeridos pela revisão teórica a respeito da internacionalização de empresas. Nesse ponto, os trechos foram classificados de acordo com a etapa do processo de internacionalização à qual pertencem: por que sair; para onde ir (por que esse local); como entrar e como se adaptar (Apêndices 3 a 12).

O estágio seguinte foi a elaboração das proposições que compõem cada uma das 11 categorias. ${ }^{5}$ Cada categoria representa uma teoria sobre internacionalização de empresa: Teoria do Poder de Mercado, Teoria do Ciclo do Produto, Teoria da Internalização, Paradigma Eclético, Escola de Uppsala, Escola Nórdica de Negócios Internacionais, Teoria

\footnotetext{
${ }^{5}$ Assim como em Bardin (2004), nesta tese o termo "categoria" é empregado com o sentido de "variável".
} 
sobre Competição e Competitividade Global, Abordagem sobre Gestão Estratégica de Operações, Abordagem sobre Gestão de Competências, Abordagem sobre Gestão do Conhecimento e Abordagem Intercultural. Cada categoria é representada por um conjunto de proposições (Apêndice 2). ${ }^{6}$

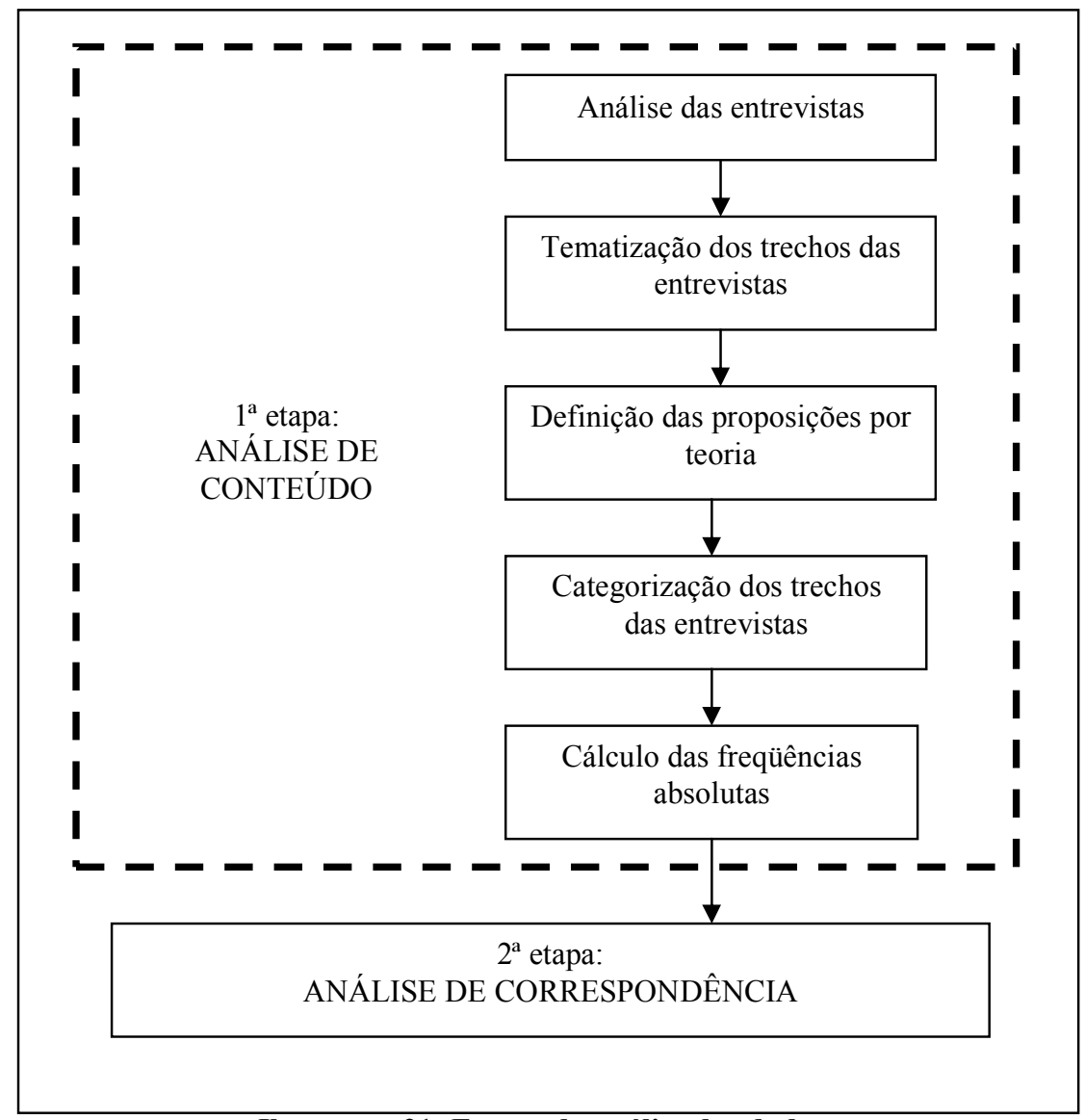

Ilustração 21- Etapas da análise dos dados

Os trechos também foram categorizados de acordo com as proposições que representam cada teoria sobre internacionalização. Segundo Bardin (2004), o processo de categorização deve obedecer ao critério da exclusão mútua, onde cada elemento não pode existir em mais de uma

\footnotetext{
${ }^{6}$ Para Japiassú e Marcondes (1999, p. 223), “(lat. Propositivo). Formulação lingüística de um juízo, podendo ser verdadeira ou falsa. Tradicionalmente considera-se o juízo como um ato mental e a proposição como uma expressão lingüística. Alguns filósofos da linguagem contemporâneos distinguem, por vezes, a proposição como uma estrutura lógica e formal, pertencendo à linguagem portanto, e a sentença como a expressão de uma proposição em uma língua particular. Há, no entanto, inúmeras controvérsias quanto à natureza mental ou lingüística da proposição, a relação entre proposição em um sentido abstrato, genérico e sua instanciação em uma língua concreta, a atribuição de verdade e falsidade a proposições ou a sentenças etc.”. Durozoi e Roussel (1996, p. 385) definem proposição como "no sentido próprio: enunciado verbal suscetível de ser qualificado de verdadeiro ou falso, do qual se pode considerar que subentende um juízo pelo menos virtual". Para Durozoi e Roussel (1996, p. 266), "logicamente, o juízo consiste em colocar uma relação entre dois ou mais termos. Por isso, apresenta-se em geral sob a forma de um sujeito unido a um predicado por intermédio de uma cópula".
} 
divisão. Entretanto, os trechos das entrevistas foram relacionados a uma ou mais proposições. Isso se deve ao fato de que as teorias sobre internacionalização têm, na maioria das vezes, as mesmas raízes conceituais. Assim sendo, há elementos constitutivos comuns a mais de uma teoria, enfoque ou abordagem. Como conseqüência, é possível e válido um trecho ser atribuído a mais de uma categoria (Apêndices de 3 a 12).

O último estágio da Análise de Conteúdo compreendeu o cálculo das freqüências absolutas dos trechos das entrevistas classificados por teoria. Após esses procedimentos, os trechos das entrevistas foram comparados por meio da Análise de Correspondência com vistas a apresentar graficamente a relação entre o discurso dos entrevistados e as teorias sobre internacionalização de empresas.

Os resultados da Análise de Conteúdo e da Análise de Correspondência são apresentados no capítulo 4. Por fim, no capítulo 5, são registradas as inferências que esta pesquisa propiciou, as limitações inerentes ao escopo, amplitude e método de pesquisa, bem como as sugestões para outros estudos. 


\section{ANÁLISE DOS DADOS}

\subsection{Introdução}

Os resultados obtidos a partir da análise das entrevistas em profundidade com os gestores das empresas Arezzo, Carmen Steffens, Chilli Beans, Lilica Ripilica (Marisol), Morana, Mundo Verde, Nobel, O Boticário, Spoleto e Victor Hugo são apresentados neste capítulo, com o intuito de atender aos objetivos traçados no capítulo 1 deste trabalho. A primeira parte da análise disponibiliza a caracterização das empresas ${ }^{7}$ e dos entrevistados. A segunda parte apresenta os resultados que respondem ao problema de pesquisa desta tese e procura demonstrar a relação existente entre as teorias sobre internacionalização de empresas e o processo de expansão de empresas de varejo brasileiras para países estrangeiros. Cabe a esta pesquisa atender ao objetivo principal de identificar o que leva uma empresa a se deslocar para outros países, os lugares para onde se desloca (por que escolhe determinados locais em detrimento de outros), os modos de entrada selecionados e como as empresas se adaptam aos novos locais, sob os conceitos da internacionalização de empresas. Além disso, cabe demonstrar de que maneira o método de Análise de Conteúdo pode ser empregado em pesquisas da área de Administração.

\subsection{Caracterização das empresas pesquisadas}

A caracterização das empresas pesquisadas é apresentada nos subitens desta seção. No Quadro 2, pode-se observar a descrição dos entrevistados. O Quadro 3 disponibiliza dados sobre planos futuros de expansão internacional de cada uma das dez empresas pesquisadas. $\mathrm{O}$ Apêndice 13 organiza as etapas de internacionalização de cada empresa, destacando locais, datas e modos de entrada nos países estrangeiros.

\footnotetext{
${ }^{7}$ Não foram encontrados dados sobre a internacionalização do setor - varejo de bens e serviços -, apesar de terem sido consultados os relatórios do WIR (World Investment Report), WTO (World Trade Organization), IBGE (Instituto Brasileiro de Geografia e Estatística), IPEA (Instituto de Pesquisa Econômica Aplicada), ABF (Associação Brasileira de Franchising) e Internet.
} 
Quadro 2 - Caracterização dos entrevistados

\begin{tabular}{|c|c|c|c|c|}
\hline $\begin{array}{l}\text { Nome da } \\
\text { empresa }\end{array}$ & $\begin{array}{l}\text { Setor de } \\
\text { atividade }\end{array}$ & Cargo do entrevistado & $\begin{array}{c}\text { Papel no processo } \\
\text { internacional }\end{array}$ & $\begin{array}{c}\text { Início da } \\
\text { internacionalização }\end{array}$ \\
\hline Arezzo & $\begin{array}{c}\text { Calçados, } \\
\text { artigos de couro } \\
\text { e acessórios }\end{array}$ & $\begin{array}{l}\text { Diretor executivo da } \\
\text { área internacional }\end{array}$ & $\begin{array}{l}\text { Responsável pela área } \\
\text { internacional }\end{array}$ & 1990 \\
\hline $\begin{array}{l}\text { Carmen } \\
\text { Steffens }\end{array}$ & $\begin{array}{l}\text { Calçados, bolsas } \\
\text { e acessórios }\end{array}$ & $\begin{array}{l}\text { Sócio e diretor } \\
\text { internacional de } \\
\text { expansão }\end{array}$ & $\begin{array}{l}\text { Responsável pelo } \\
\text { projeto internacional }\end{array}$ & 2001 \\
\hline Chilli Beans & $\begin{array}{l}\text { Acessórios de } \\
\text { moda }\end{array}$ & $\begin{array}{l}\text { Diretor de expansão e } \\
\text { marketing }\end{array}$ & $\begin{array}{c}\text { Planejamento e } \\
\text { estratégia de } \\
\text { internacionalização }\end{array}$ & $\begin{array}{c}\text { Fim de } 2002 \text { e } \\
\text { começo de } 2003\end{array}$ \\
\hline Lilica Ripilica & $\begin{array}{c}\text { Confeccionados } \\
\text { têxteis e } \\
\text { calçados } \\
\end{array}$ & $\begin{array}{c}\text { Diretor da área } \\
\text { comercial nacional e } \\
\text { internacional }\end{array}$ & $\begin{array}{l}\text { Responsável pelo } \\
\text { projeto internacional }\end{array}$ & 2001 \\
\hline Morana & $\begin{array}{l}\text { Acessórios de } \\
\text { moda }\end{array}$ & Sócio e diretor & $\begin{array}{l}\text { Responsável pela } \\
\text { internacionalização }\end{array}$ & 2007 \\
\hline Mundo Verde & $\begin{array}{c}\text { Produtos } \\
\text { naturais e bem- } \\
\text { estar }\end{array}$ & Sócio fundador & $\begin{array}{c}\text { Coordenador do } \\
\text { projeto internacional }\end{array}$ & 2007 \\
\hline Nobel & $\begin{array}{l}\text { Livraria e } \\
\text { papelaria }\end{array}$ & $\begin{array}{l}\text { Sócio e diretor de } \\
\text { operações }\end{array}$ & $\begin{array}{l}\text { Área de franquias, } \\
\text { internacionalização e } \\
\text { relacionamento com } \\
\text { parceiros }\end{array}$ & 2005 \\
\hline O Boticário & Cosméticos & Diretor internacional & $\begin{array}{l}\text { Expatriar o modelo de } \\
\text { negócio, pessoas, } \\
\text { tecnologia e marca }\end{array}$ & 1986 \\
\hline Spoleto & Alimentação & $\begin{array}{l}\text { Gerente de expansão } \\
\text { internacional }\end{array}$ & $\begin{array}{c}\text { Prospecção de } \\
\text { parceiros, modelagem } \\
\text { de operação, suporte e } \\
\text { projeto }\end{array}$ & $\begin{array}{l}1999 \text { (primeiro } \\
\text { registro) } \\
\text { e depois em } 2005\end{array}$ \\
\hline Victor Hugo & $\begin{array}{l}\text { Artefatos de } \\
\text { couro }\end{array}$ & $\begin{array}{c}\text { Consultor de } \\
\text { internacionalização }\end{array}$ & $\begin{array}{c}\text { Coordenar a } \\
\text { internacionalização }\end{array}$ & 2005 \\
\hline
\end{tabular}

\subsubsection{Arezzo}

A Arezzo foi fundada em 1972, pelos irmãos Anderson e Jefferson Birman. A empresa é fabricante de calçados e atua no varejo desse setor, além do de artigos de couro e acessórios. Em 2007 nasceu a Arezzo S/A, empresa resultante da união da Arezzo com a Schutz, e no mesmo ano o Tarpon Investment Group adquiriu 25\% do controle acionário da Arezzo. A empresa conta hoje com 227 lojas no Brasil e sete lojas no exterior (AREZZO).

A Arezzo começou como uma distribuidora, participando de feiras de calçados e vendendo em todas as multimarcas, ainda no Brasil, antes de ser um sistema de franquias. Como fabricante, a Arezzo exportava calçados para vários países, entre eles os Estados Unidos. Tornou-se mais conhecida a partir dos anos 90, quando, com a abertura proporcionada pelo Plano Collor, houve a entrada de muitos produtos estrangeiros no Brasil e, ao mesmo tempo, o produto brasileiro foi exportado. Assim, o movimento de exportação da Arezzo aconteceu 
nos últimos dez anos. O modelo de operação adotado inicialmente era a distribuição atacadista; mais tarde, a partir de 2004, abriu-se outro canal para distribuição internacional, com lojas no sistema de franquia. A primeira loja foi no Paraguai, e depois vieram as lojas da Venezuela, em 2005, Arábia Saudita (de 2005 a 2007) e Portugal, em 2007. Serão abertas 12 lojas na China. Hoje, a Arezzo está em mais de 50 países. A operação das lojas é feita por equipes de cada país, seguindo as orientações da matriz no Brasil. As orientações são fornecidas por coordenadora brasileira, que visita as lojas periodicamente, e por meio de treinamentos que acontecem no Brasil de três a quatro vezes por ano.

\subsubsection{Carmen Steffens}

A Carmen Steffens surgiu em 1981, na cidade de Franca (Brasil), como um curtume, que também fornece matéria-prima para as marcas Hugo Boss e Timberland. Em 1993, a empresa passou a fabricar e comercializar calçados, bolsas e acessórios. A marca é comercializada em 400 lojas multimarcas no Brasil e possui 120 lojas no Brasil e 17 no exterior, todas elas no sistema de franquia. A empresa conta com mais de mil funcionários (CARMEN STEFFENS).

A expansão internacional começou no ano de 2001, com a abertura de uma loja franqueada em Assunción, no Paraguai. Antes dessa data, a Carmen Steffens já exportava por intermédio de feiras para distribuidores. Depois, abriu lojas franqueadas em Punta del Este (Uruguai), em 2003, Portugal, Los Angeles (Estados Unidos) e, em 2007, na Austrália. Embora os padrões de operação sejam estabelecidos na matriz brasileira, as lojas nesses países são geridas por dois escritórios compostos por equipes locais, um deles sediado em Portugal e o outro em Los Angeles. Hoje os negócios internacionais representam cerca de $20 \%$ do faturamento da empresa.

\subsubsection{Chilli Beans}

A Chilli Beans iniciou suas atividades em 1996, sob o comando do empresário Caito Maia, que abriu um pequeno estande no Mercado Mundo Mix, comercializando óculos de sol com design focado nas tendências fashion. O Mercado Mundo Mix era uma feira de moda voltada para o público jovem, que acontecia em São Paulo. Em 1997, o empresário inaugurou sua primeira loja na Galeria Ouro Fino, na Rua Augusta, em São Paulo. Hoje, além dos óculos, 
comercializa relógios. Os produtos são fabricados na China, em Taiwan, na Argentina e no Brasil. (CHILLI BEANS)

Em 2002, a empresa foi procurada por um investidor inglês interessado em levá-la para a Inglaterra. Os gestores preferiram não iniciar a operação naquele momento, em função da ausência de estrutura. Entretanto, iniciou-se um processo de preparação para uma possível expansão internacional posterior. Entre o fim de 2002 e o início de 2003, a Chilli Beans foi consultada por portugueses querendo levar a marca para Portugal. A primeira loja foi inaugurada em 2005, em Lisboa. Nesse momento, decidiu-se testar a marca em outro mercado, distinto do português: o mercado americano. Foi aberta uma loja em Los Angeles, Califórnia, pois o fundador da Chilli Beans havia morado lá.

A Chilli Beans conta hoje com cinco lojas em Portugal e uma nos Estados Unidos. No Brasil são 205 lojas em funcionamento e 49 a ser inauguradas em 2009. As lojas do exterior têm em média quatro funcionários por ponto de venda, o que totaliza 24 funcionários. Um gerente brasileiro mora nos Estados Unidos e cuida da operação nesse país; um supervisor brasileiro viaja de dois em dois meses a Portugal.

\subsubsection{Lilica Ripilica}

A marca Lilica Ripilica faz parte da empresa catarinense Marisol, que pertence ao setor de atividade de confeccionados têxteis e calçados. A Marisol, que surgiu em 1964, em Santa Catarina, responde tanto pela produção como pela comercialização de seus produtos. $\mathrm{O}$ grupo conta com oito diferentes marcas: Marisol, Tigor T. Tigre, Lilica Ripilica, Worghon, Pakalolo, Mineral, Criativa e Maju. A empresa foi fundada há 44 anos e atua no mercado internacional por meio de exportação há cerca de 20 (MARISOL).

A empresa conta com 5 mil colaboradores e tem capacidade instalada para produzir mais de 25 milhões de peças de roupas e 3,2 milhões de pares de calçados infantis por ano. Presente em mais de 14 mil pontos de vendas multimarcas e com 80 franquias exclusivas, a Marisol S.A. é líder no segmento de confecção infantil dentro do mercado brasileiro e no segmento de franquias monomarcas infantis. 
A Lilica Ripilica é uma marca de produtos e um modelo de loja que nasceu em 1991. Os produtos da linha se destinavam às meninas de 2 a 8 anos de idade, das classes A e B. Para representar a personagem Lilica Ripilica foi escolhido um coala. A internacionalização da marca Lilica Ripilica teve início por meio de exportação, em 2001. No mesmo ano, um investidor libanês abriu quatro lojas no Líbano (operação tipo master-franquia, mas sem contrato). A empresa conta com 140 lojas franqueadas no Brasil e possui lojas no México (1), na Guatemala (1), Costa Rica (1), Colômbia (3), no Peru (2), Chile (1), Portugal (1), na Espanha (1) e Itália (loja e escritório). As lojas do exterior são geridas por equipes locais, e todas as equipes recebem treinamentos no Brasil e em seus próprios países, por meio de um consultor brasileiro que visita as lojas seis vezes ao ano.

\subsubsection{Morana}

A empresa iniciada pela Sra. Hyun Lee, de origem coreana, surgiu em 1979, com uma operação de jóias na Rua Augusta, em São Paulo. Em 1998 seus filhos iniciaram a cadeia de restaurantes fast food de gastronomia asiática Jin Jin. Mais tarde, em 2002, lançaram a Morana, com o objetivo de, por meio de franchising, criar uma rede de acessórios femininos no país. O conceito de negócio Balonè foi concebido em meados de 2007, com o objetivo de se tornar uma rede de lojas de acessórios femininos voltada ao público infantil e infantojuvenil, também por meio de franquias. As três marcas compõem o Grupo Ornatus (MORANA).

Com a abertura do mercado na década de 90, resultante do Plano Collor, houve a entrada no país de empresas concorrentes do Grupo Ornatus. Associado a esse fato, a Morana ampliou sua operação no mercado brasileiro e desenvolveu um plano para expansão internacional. Em 2007 abriu sua primeira loja em Portugal, na cidade do Porto. No mesmo ano abriu uma loja no bairro do Soho, em Nova York, e em Los Angeles (Estados Unidos). No Brasil, são 90 lojas com um total de 600 funcionários; no exterior, são 12 funcionários.

\subsubsection{Mundo Verde}

A marca Mundo Verde surgiu em 1987, a partir da preocupação de Isabel Maria Antunes Joffe em criar as filhas com alimentos saudáveis. Junto do marido, Elísio Joffe, e dos irmãos, Jorge e Arlindo Antunes, ela fundou a loja de 25 metros quadrados e com apenas um 
funcionário, na cidade de Petrópolis, região serrana do estado do Rio de Janeiro. O Mundo Verde comercializa produtos naturais e para bem-estar, como música new age, cosméticos, produtos para quem freqüenta academia, diet, light, incensos. São 140 lojas no Brasil, com cerca de mil funcionários (MUNDO VERDE).

A idéia de internacionalizar a empresa surgiu após muitas sugestões e pedidos de clientes de várias partes do mundo para levar a franquia Mundo Verde para os seus respectivos países. A primeira loja internacional foi aberta em Angola, em 2007. O modelo de operação adotado foi a master-franquia: a operação da loja de Angola fica a cargo do master-franqueado com equipe local, e apenas o gerente de loja é brasileiro (expatriado). Os próximos passos internacionais prevêem a abertura de outras lojas em Angola, além de lojas em Portugal e, ainda, um terceiro país, que está sendo estudado.

\subsubsection{Nobel}

A Nobel foi fundada há 60 anos e atua como editora, atacadista, varejista de livros em português e papelaria (NOBEL). Iniciou seu processo de internacionalização por meio de exportação de livros em português para Portugal e Angola. Em 2005 a empresa tomou a iniciativa de participar de uma feira de franquias na cidade do Porto, em Portugal, onde estabeleceu parceria com um empresário português que passou a ser o primeiro masterfranqueado. No ano seguinte, expondo em uma feira na Espanha, identificou um parceiro e comercializou a master-franquia para a Espanha e Angola. As operações no exterior são geridas por equipes locais com o suporte da matriz no Brasil. Esse suporte envolve o deslocamento de um componente da equipe brasileira até o local solicitante.

\subsubsection{O Boticário}

O Boticário foi fundado por Miguel Krigsner, que transformou uma pequena farmácia de manipulação, aberta em 1977, no centro de Curitiba (PR), numa rede de franquias de perfumaria e cosméticos. Atualmente, O Boticário possui mais de 2.660 lojas no Brasil, presença em mil pontos de venda e 73 lojas exclusivas em outros 15 países. Os produtos são comercializados em lojas exclusivas, departamentais e multimarcas (O BOTICÁRIO). 
O Boticário teve sua primeira presença internacional nos Estados Unidos, mas a operação foi fechada mais tarde. Em 1986 abriu sua primeira loja franqueada em Portugal, onde há hoje cerca de 80 pontos de venda, entre lojas, quiosques e lojas multimarcas. Atua nos Estados Unidos, Japão, Peru, Uruguai, Paraguai, em Portugal, Cabo Verde, Angola, Moçambique, na Arábia Saudita, Venezuela, Colômbia, África do Sul, República Dominicana e Namíbia. A empresa estruturou uma diretoria própria com equipe dedicada aos assuntos internacionais na matriz, em Curitiba.

\subsubsection{Spoleto}

O Spoleto iniciou sua operação em 1999, no Rio de Janeiro, com a associação de Eduardo Ourivio e Mário Chady. O conceito do Spoleto é alimentação fast casual, com operação e conceito de expansão por meio de franquia desde a sua fundação (SPOLETO). Em 2005 o Spoleto passou a se chamar Grupo Úmbria, como parte da estratégia de operar multimarcas no Brasil.

O primeiro registro de marca internacional aconteceu no fim de 1999, ou seja, no primeiro ano de operação da empresa, quando ela possuía apenas duas lojas no Brasil. Nessa ocasião, o registro da marca já foi depositado fora do país, em função da clara intenção de expandir o negócio internacionalmente. Em 2005 a empresa fez uma joint-venture (com contrato de master-franquia) com o Grupo Alsea para operar a Domino's Pizza no Brasil; em contrapartida, o Grupo Alsea assumiria o compromisso de levar o Spoleto para o México. O período de 2005 até o final de 2006 abrangeu a primeira fase, de implementação do projeto, e a segunda fase, de transição do Grupo Alsea (que deixou o negócio) para o Grupo Sernas, que assumiu a operação no México.

Em 2006 a empresa iniciou a negociação com um grupo português, que abriu uma cópia do Spoleto em Portugal. No mesmo ano, o Spoleto estabeleceu uma master-franquia na Espanha. Atualmente, a empresa possui 185 lojas (entre as que estão em funcionamento e as ainda em construção) no Brasil, cinco lojas na Espanha e oito no México. Para dar suporte às unidades em países estrangeiros há dois treinadores que, a cada início de projeto, ficam três meses morando no país. 


\subsubsection{Victor Hugo}

A marca de bolsas Victor Hugo teve origem no nome de seu criador, um uruguaio radicado no Brasil. A empresa comercializa bolsas e pertence ao setor de artefatos de couro. O próprio Victor Hugo vendia na feira hippie de Ipanema (Rio de Janeiro), na Praça da Paz, há 35 anos. Montou uma pequena oficina, onde ele mesmo fazia as peças e as vendia. O negócio foi crescendo e o empresário passou do artesanato para a indústria. Resolveu montar uma loja e, nessa ocasião, comprou uma fábrica que tinha sido da Vuitton, mantendo toda a equipe que já estava lá. A fábrica fechou, mas com essa equipe a empresa cresceu.

Com a abertura do mercado, na década de 90, as marcas internacionais Prada, Vuitton e Gucci entraram no Brasil. Até essa data, Victor Hugo era líder de mercado em bolsas e artigos de luxo no Brasil. Com a entrada das marcas estrangeiras, a Victor Hugo perdeu mercado. Criou a bolsa Nikita, que representava um grande volume de vendas, mas baixa margem de lucro, insuficiente para sustentar a fábrica. Frente à situação, seu fundador resolveu concorrer com as marcas internacionais no mercado brasileiro.

O resultado desse posicionamento foi que, em 2000, a empresa desenvolveu a maior coleção de bolsas feitas com peles exóticas do mundo. Abriu escritórios em Nova York e Florença para pesquisa de materiais e tendências. As matérias-primas como o jacquard italiano, algumas ferragens e principalmente os curtumes eram os italianos, pois os curtumes brasileiros não eram tão sofisticados.

Em 2001 várias pessoas queriam levar a Victor Hugo para o exterior. Como ela já estava posicionada junto às marcas de luxo no mercado brasileiro e havia demanda internacional, seu fundador resolveu internacionalizar a empresa. Decidiu abrir sua primeira loja em Nova York, em virtude de considerar o local a vitrine de mercadorias de luxo para o mundo. A pesquisa de ponto para a loja se iniciou em 2001, mas a inauguração só ocorreu em 2005, em frente às lojas da Dior e da Montblanc.

A empresa conta com 60 lojas exclusivas, das quais 12 são próprias, e 300 corners em lojas multimarcas. Fora do Brasil, tem lojas em Portugal e nos Estados Unidos (Nova York). A empresa mantém em Portugal oito funcionários, nas funções de operação de loja, como gerente e vendedores. O gerente é brasileiro, metade dos vendedores são brasileiros expatriados e metade são brasileiros que já moravam em Portugal antes de trabalhar na Victor 
Hugo. Já em Nova York a equipe é inteira brasileira. Ali há, além da loja, o escritório, com oito pessoas, no total. A loja e o escritório servem como atacado para outros varejos dentro dos Estados Unidos (lojas multimarcas). No Brasil, contando fábrica, escritório e lojas, há quase 2 mil funcionários. A fabricação é parte própria e parte terceirizada. As marcas de propriedade da empresa estão todas registradas fora do Brasil, no Uruguai, em função da nacionalidade do fundador.

O fator mais abordado pelos entrevistados como impulsionador da expansão internacional foi a abertura do mercado brasileiro ocorrida na década de 90, com o Plano Collor. Como conseqüência, empresas oriundas de outros países passaram a oferecer seus produtos no mercado brasileiro ou mesmo estabeleceram operação no Brasil. As empresas pesquisadas passaram a enfrentar o desafio de competir com novos concorrentes. Nesse cenário, tornaramse visíveis para investidores estrangeiros, gerando oportunidades (convites) para levar seus negócios para outros lugares. Presenciaram também a ampliação da oferta de produtos similares aos seus no mercado brasileiro, o que empurrou (push factor) suas empresas para países estrangeiros, como reação à ameaça percebida a partir daquele momento.

O processo de internacionalização dessas empresas teve principalmente um caráter reativo. Os países onde estabeleceram sua primeira operação internacional foram, de um lado, função da concentração de empresas concorrentes, como foi o caso da Victor Hugo, quando escolheu Nova York para sua primeira loja. De outro, a escolha teve origem nos convites feitos por empresários estrangeiros, como aconteceu com a Arezzo, Carmen Steffens, Chilli Beans, Morana, Mundo Verde, Nobel e O Boticário. Ou, ainda, a escolha partiu de um esforço para competir no mercado, como a Marisol. A exceção é a empresa Spoleto, que já surgiu com a intenção de atuar internacionalmente (Apêndices de 3 a 12).

A escolha do segundo e dos demais países decorreu principalmente de oportunidades geradas por investidores estrangeiros querendo levar as marcas para seu país de origem ou para países onde já atuavam. Apenas a Morana estabeleceu operação em país onde um dos donos foi morar (Los Angeles, Estados Unidos). A Marisol procurou parceiros para fazer frente à concorrência e o Spoleto planejou a pesquisa de possíveis parcerias para estabelecer operação internacional. 
Já a fase de futuras expansões de cada uma das empresas pesquisadas é marcada pela mudança no padrão do processo de internacionalização. Os entrevistados chamam a atenção para o fato de que a ampliação da atuação internacional está sendo planejada e sofre a influência das experiências vividas no mercado estrangeiro até o momento e do compartilhamento das experiências com outras empresas brasileiras que operam no estrangeiro (Quadro 3).

Quadro 3 - Futura expansão internacional

\begin{tabular}{|c|c|}
\hline Nome da empresa & Futura expansão internacional \\
\hline Arezzo & $\begin{array}{l}\text { - Arábia Saudita; } \\
\text { - Europa: expansão; } \\
\text { - China: abrindo } 12 \text { lojas (até 2012, } 207 \text { lojas); } \\
\text { - América Latina; } \\
\text { - países ibéricos; } \\
\text { - países da África; } \\
\text { - países onde não há operação. }\end{array}$ \\
\hline Carmen Steffens & $\begin{array}{l}\text { - Buenos Aires; } \\
\text { - Espanha; } \\
\text { - Las Vegas; } \\
\text { - Grécia; } \\
\text { - até 2020, } 100 \text { lojas; } \\
\text { - Estados Unidos; } \\
\text { - ampliar participação nos países onde já atua. }\end{array}$ \\
\hline Chilli Beans & $\begin{array}{l}\text { - Estados Unidos: vender a franquia; } \\
\text { - Alemanha; } \\
\text { - Dubai; Oriente Médio: } 15 \text { pontos; } \\
\text { - store-in-store; lojas nos aeroportos; minilojas; } \\
\text { - Panamá; } \\
\text { - Colômbia; } \\
\text { - Venezuela; } \\
\text { - Chile. }\end{array}$ \\
\hline Lilica Ripilica & $\begin{array}{l}\text { - Panamá; } \\
\text { - vias caribenhas; } \\
\text { - Portugal; } \\
\text { - Peru; } \\
\text { - América do Sul. }\end{array}$ \\
\hline Morana & $\begin{array}{l}\text { - Los Angeles: duas ou três lojas próprias; } \\
\text { - Estados Unidos: em cinco anos abrir } 5 \text { mil lojas; } \\
\text { - Madri. }\end{array}$ \\
\hline Mundo Verde & $\begin{array}{l}\text { - Angola; } \\
\text { - Lisboa; } \\
\text { - um ou dois países por ano. }\end{array}$ \\
\hline Nobel & $\begin{array}{l}\text { - Angola; } \\
\text { - Argentina; } \\
\text { - Colômbia; } \\
\text { - Estados Unidos. }\end{array}$ \\
\hline O Boticário & - Não ampliar operações; aperfeiçoar a operação existente. \\
\hline Spoleto & $\begin{array}{l}\text { - Península Ibérica: } 50 \text { lojas em cinco anos; } \\
\text { - Estados Unidos. }\end{array}$ \\
\hline Victor Hugo & $\begin{array}{l}\text { - Portugal: duas lojas; } \\
\text { - 2009: Espanha, França, Itália, Londres; } \\
\text { - Europa: } 60 \text { lojas e centenas de multimarcas em dez anos; } \\
\text { - Madri, Barcelona, Paris: flagship; } \\
\text { - Leste Europeu; } \\
\text { - Estados Unidos. }\end{array}$ \\
\hline
\end{tabular}




\subsection{O processo de internacionalização das empresas de varejo brasileiras: proposições}

A análise dos dados abrangeu a execução da Análise de Conteúdo das entrevistas e a Análise de Correspondência. A fim de mostrar a proximidade entre o discurso dos empresários e as teorias estudadas, foi aplicada a Análise de Correspondência, empregando o software SPAD. A análise foi feita considerando o processo como um todo e também cada uma de suas quatro partes, separadamente. Essa técnica permite demonstrar graficamente as proximidades e as distâncias entre empresas e teorias por meio dos dados que se encontram nas tabelas de contingência (Tabelas de 1 a 4). Nessas tabelas pode-se observar o número de vezes que cada proposição foi identificada em cada entrevista na íntegra. Por meio dessa contagem, é possível construir uma medida de distância entre as empresas e as teorias e representar as empresas e as proposições das teorias num mesmo gráfico com dimensão reduzida (duas dimensões), respeitando ao máximo essas distâncias.

As Tabelas 5 e 6 apresentam a freqüência das proposições de cada entrevista que representam os motivos que levam cada uma das empresas a se deslocar para outro país - por que sair. As Tabelas 7 e 8 mostram a freqüência das proposições relativas ao local para onde as empresas se deslocam e por que escolhem determinado local em detrimento de outros - para onde ir. As Tabelas de 9 a 12 indicam a freqüência das proposições relacionadas aos modos de entrada nos países estrangeiros selecionados por cada empresa - como entrar no novo local. E as Tabelas de 13 a 15 disponibilizam a freqüência das proposições que se referem às adaptações feitas na operação em cada país após a entrada - como se adaptar ao novo local.

A análise considera o texto das entrevistas na íntegra e também cada uma de suas partes isoladamente. Dessa maneira, é possível observar quais proposições das teorias têm relação mais próxima com cada uma das etapas do processo de internacionalização de cada empresa e também com o processo de internacionalização como um todo. As proposições não identificadas nas entrevistas não foram incluídas nas tabelas. Embora a inércia (porcentagem da variabilidade original dos dados preservada pela Análise de Correspondência) para as análises construídas considerando empresas e teorias possa ser considerada baixa, nos casos em que apenas dois eixos são adotados esse número de dimensões mostra-se representativo de praticamente todas as proposições mencionadas, o que é de interesse do estudo. A inclusão de 
mais uma dimensão não traria melhoras tão significativas a ponto de justificar o aumento de complexidade na análise, considerando mais dimensões.

Uma empresa estará mais próxima de uma proposição quanto maior for a quantidade de trechos da entrevista classificados com essa proposição, e estará mais distante dos elementos que são pouco referidos. Os resultados da Análise de Correspondência são mapas perceptuais, que podem ser visualizados nos Gráficos de 1 a 11, nos itens a seguir.

\subsubsection{Análise dos dados por proposição e por empresa para a totalidade do processo de internacionalização}

A análise dos dados registrados nas Tabelas de 1 a 4 mostra que a teoria com maior incidência é a Teoria sobre Competição e Competitividade Global, apresentando um total de 408 registros. Em segundo lugar aparece a Escola de Uppsala, com 211 registros, e em terceiro lugar, a Abordagem sobre Gestão Estratégica de Operações, com 78. Em quarto lugar, aparece a Abordagem sobre Gestão do Conhecimento, com 68 registros; em quinto, a Abordagem sobre Gestão de Competências, com 53; em sexto, o Paradigma Eclético, com 41; em sétimo, a Teoria do Poder de Mercado, com 16; em oitavo lugar aparece a Teoria de Internalização, com 11; em nono, a Abordagem Intercultural, com dez registros; em décimo, a Escola Nórdica, com nove. Em último lugar aparece a Teoria do Ciclo do Produto, com oito registros. Os Gráficos 1 e 2 mostram o resultado da Análise de Correspondências desses dados.

A Teoria de Competição e Competitividade Global, com a maior quantidade de trechos nas entrevistas, teve todas as suas seis proposições identificadas. A proposição CC 1 - a empresa determina sua estratégia em função da excelência operacional - apresentou um registro nas entrevistas da Chilli Beans, Lilica Ripilica, Morana, Mundo Verde, Nobel, O Boticário e Victor Hugo. A proposição CC 2 - a empresa determina sua estratégia pela análise de produtos - foi identificada na Lilica Ripilica (7), Victor Hugo (3), Mundo Verde (2), O Boticário (2), Carmen Steffens (2) e Nobel (1). A proposição CC 3 - a empresa define sua estratégia pela análise de concorrentes - apresentou registros nas entrevistas da Victor Hugo (7), Carmen Steffens (5), Morana (4), Chilli Beans (2), Lilica Ripilica (2), Mundo Verde (1), Nobel (1) e. Arezzo (1) Apenas O Boticário e Spoleto não apresentaram trecho relativo a essa proposição. A proposição CC 4 - a empresa define sua estratégia pela análise de 
consumidores - foi percebida na Victor Hugo (8), Carmen Steffens (3), Chilli Beans (2), Lilica Ripilica (2), Morana (1), Mundo Verde (1), O Boticário (1) e Spoleto (1). A proposição CC 5 - a empresa determina sua estratégia pela análise de oportunidades - apresentou a segunda maior incidência nas entrevistas, colaborando com 121 trechos. Todas as empresas apresentaram trechos dessa proposição: Arezzo (23), Mundo Verde (21), Morana (18), Lilica Ripilica (11), Carmen Steffens (11), Chilli Beans (10), Nobel (9), Spoleto (8) O Boticário (7) e Victor Hugo (3). A proposição que apresentou maior ocorrência nas entrevistas foi a CC 6 a empresa define seu posicionamento estratégico para atuar em novo local. Todas as empresas apresentaram trechos relacionados a ela: Chilli Beans (32), Arezzo (31), Lilica Ripilica (29), Carmen Steffens (29), Victor Hugo (24). , O Boticário (20), Spoleto (20), Nobel (15), Morana (14) e Mundo Verde (7).

Tabela 1 - Freqüência das proposições por entrevista: $1^{\text {a }}$ parte

\begin{tabular}{|c|c|c|c|c|c|c|c|c|c|c|c|c|c|c|c|}
\hline \multirow{2}{*}{ Empresa } & \multicolumn{3}{|c|}{$\begin{array}{l}\text { Poder de } \\
\text { Mercado }\end{array}$} & \multicolumn{4}{|c|}{$\begin{array}{l}\text { Ciclo do } \\
\text { Produto }\end{array}$} & \multicolumn{3}{|c|}{ Internalização } & \multicolumn{5}{|c|}{$\begin{array}{l}\text { Paradigma } \\
\text { Eclético }\end{array}$} \\
\hline & PM 1 & PM 2 & PM 7 & $\mathrm{CP} 4$ & CP 6 & CP7 & CP 8 & IN 3 & IN 4 & IN 5 & PE 1 & PE 3 & PE 6 & PE 7 & PE 8 \\
\hline Arezzo & 0 & 0 & 1 & 0 & 0 & 0 & 0 & 0 & 0 & 0 & 0 & 1 & 0 & 0 & 1 \\
\hline $\begin{array}{l}\text { Carmen } \\
\text { Steffens }\end{array}$ & 0 & 0 & 1 & 0 & 0 & 0 & 0 & 0 & 0 & 1 & 3 & 0 & 0 & 0 & 0 \\
\hline Chilli Beans & 0 & 0 & 0 & 0 & 0 & 0 & 0 & 0 & 0 & 0 & 2 & 1 & 0 & 0 & 2 \\
\hline $\begin{array}{c}\text { Lilica } \\
\text { Ripilica }\end{array}$ & 0 & 0 & 0 & 0 & 0 & 0 & 1 & 0 & 2 & 0 & 1 & 0 & 0 & 0 & 2 \\
\hline Morana & 0 & 0 & 2 & 0 & 1 & 0 & 0 & 0 & 1 & 3 & 0 & 0 & 0 & 0 & 3 \\
\hline $\begin{array}{l}\text { Mundo } \\
\text { Verde }\end{array}$ & 0 & 0 & 0 & 0 & 0 & 0 & 0 & 0 & 0 & 0 & 2 & 0 & 0 & 0 & 0 \\
\hline Nobel & 1 & 0 & 1 & 1 & 0 & 0 & 0 & 0 & 0 & 0 & 3 & 0 & 0 & 0 & 0 \\
\hline O Boticário & 0 & 0 & 1 & 0 & 4 & 0 & 0 & 0 & 0 & 0 & 0 & 0 & 0 & 0 & 0 \\
\hline Spoleto & 4 & 2 & 1 & 0 & 0 & 0 & 0 & 1 & 0 & 0 & 0 & 0 & 0 & 0 & 0 \\
\hline Victor Hugo & 0 & 0 & 2 & 0 & 0 & 1 & 0 & 1 & 1 & 1 & 9 & 0 & 2 & 1 & 8 \\
\hline $\begin{array}{c}\text { Total por } \\
\text { proposição }\end{array}$ & 5 & 2 & 9 & 1 & 5 & 1 & 1 & 2 & 4 & 5 & 20 & 2 & 2 & 1 & 16 \\
\hline $\begin{array}{c}\text { Total por } \\
\text { Teoria }\end{array}$ & \multicolumn{3}{|c|}{16} & \multicolumn{4}{|c|}{8} & \multicolumn{3}{|c|}{11} & \multicolumn{5}{|c|}{41} \\
\hline
\end{tabular}

A segunda maior incidência de trechos relaciona-se a Escola de Uppsala, onde dez das doze proposições podem ser identificadas nas entrevistas. A proposição EU 1 - a firma internacionaliza por meio de um processo gradual - apenas não foi identificada para Spoleto. As outras nove empresas apresentam ocorrências: Lilica Ripilica (12), O Boticário (5), Carmen Steffens (5), Victor Hugo (4), Arezzo (3), Nobel (2) e Morana, Chilli Beans e Mundo Verde com um trecho. A proposição EU 2 - a firma adquire gradativamente conhecimento do local para o qual pretende se deslocar (aprendizagem) - apresentou referências em todas as 
entrevistas, sendo a terceira proposição em termos de total de incidência nas entrevistas, com 108 trechos. Foram identificados 20 registros para a Morana, 18 para Lilica Ripilica, 17 para O Boticário, 13 para Chilli Beans, 10 para Spoleto, 9 para Carmen Steffens, 8 para Victor Hugo, 5 para Mundo Verde e 4 tanto para Arezzo, quanto para Nobel. A proposição EU 3 - a cultura em determinado local interfere no processo de expansão da empresa - apresenta trechos nas entrevistas da Morana (3), Arezzo (3), Nobel (3), Carmen Steffens (3), O Boticário (2), Chilli Beans (1) e Mundo Verde (1). A proposição EU 4 - o idioma em determinado local interfere no processo de expansão da empresa - foi identificado na Morana (3), O Boticário (3), Arezzo (2), Nobel (2), Spoleto (2) e Carmen Steffens (1). A proposição EU 6 - as praticas de negócio em determinado local interferem no processo de expansão da empresa - foi percebida na Victor Hugo (6), O Boticário (4) e Spoleto (2). A proposição EU 7 - o desenvolvimento do setor em determinado local interfere no processo de expansão da empresa - na qual verificou-se uma referência na Morana. A proposição EU 8 - o relacionamento com os clientes em determinado local interfere no processo de expansão da empresa - apresentou registros nas entrevistas da Arezzo (3), Spoleto (3), Victor Hugo (2), Morana (2), Chilli Beans (2), Lilica Ripilica (2), Mundo Verde (1) e O Boticário (1). A proposição EU 9 - o relacionamento com os fornecedores em determinado local interfere no processo de expansão da empresa - foi identificado na Lilica Ripilica e Nobel com apenas um registro em cada entrevista. A proposição EU 10 - o relacionamento com os distribuidores em determinado local interfere no processo de expansão da empresa - foi percebida na Lilica Ripilica (3), Morana (2), Chiili Beans e Nobel (1 registro para cada um dos casos). E por fim a proposição EU 11 - o relacionamento com as agências reguladoras em determinado local interfere no processo de expansão da empresa - apresentou registros para as empresas Morana e Mundo Verde com 2 trechos em cada entrevista e Victor Hugo, Chilli Beans e Nobel com apenas um.

A Abordagem sobre Gestão Estratégica de Operações apresentou trechos categorizados em quatro de suas seis proposições, foi a terceira estrutura teórica em termos de número total de trechos identificados nas entrevistas com 80 registros. A proposição EO 1 - a firma escolhe a estrutura organizacional para atuar no mercado em função das características deste mercado foi identificada na Victor Hugo (4), Morana (3), Lilica Ripilica (3), Mundo Verde (2), Carmen Steffens (2), O Boticário (1) e Spoleto (1). A proposição EO 2 - a firma escolhe a estrutura organizacional para atuar no mercado em função de suas características internas apresentou trechos nas entrevistas de todas as empresas: Mundo Verde (8), Lilica Ripilica (6), 
Chilli Beans (5), Victor Hugo (4), Morana (4), Spoleto (3), Carmen Steffens (3), Arezzo (2), O Boticário (1) e Nobel (1). A proposição EO 3 - a firma escolhe a estrutura organizacional para atuar no mercado em função da sua habilidade de gerenciar além fronteiras - foi identificado apenas um trecho na entrevista da Lilica Ripilica. A proposição EO 4 - a firma escolhe a estrutura organizacional para atuar no mercado em função de sua rede de relacionamentos internacionais - foi reconhecida na Spoleto (12), Lilica Ripilica (6), Nobel (4) e Victor Hugo (2).

Tabela 2 - Freqüiência das proposições por entrevista: $2^{a}$ parte

\begin{tabular}{|c|c|c|c|c|c|c|c|c|c|c|}
\hline \multirow[t]{2}{*}{ Empresa } & \multicolumn{10}{|c|}{$\begin{array}{c}\text { Escola de } \\
\text { Uppsala }\end{array}$} \\
\hline & EU 1 & EU 2 & EU 3 & EU 4 & EU 6 & EU 7 & EU 8 & EU 9 & EU 10 & EU 11 \\
\hline Arezzo & 3 & 4 & 3 & 2 & 0 & 0 & 3 & 0 & 0 & 0 \\
\hline Carmen Steffens & 5 & 9 & 3 & 1 & 0 & 0 & 0 & 0 & 0 & 0 \\
\hline Chilli Beans & 1 & 13 & 1 & 0 & 0 & 0 & 2 & 0 & 1 & 1 \\
\hline Lilica Ripilica & 12 & 18 & 0 & 0 & 0 & 0 & 2 & 1 & 3 & 0 \\
\hline Morana & 1 & 18 & 3 & 3 & 0 & 1 & 2 & 0 & 1 & 2 \\
\hline Mundo Verde & 1 & 5 & 1 & 0 & 0 & 0 & 1 & 0 & 0 & 2 \\
\hline Nobel & 2 & 4 & 3 & 2 & 0 & 0 & 0 & 1 & 1 & 1 \\
\hline O Boticário & 5 & 15 & 2 & 3 & 4 & 0 & 1 & 0 & 0 & 0 \\
\hline Spoleto & 0 & 10 & 0 & 2 & 2 & 0 & 3 & 0 & 0 & 0 \\
\hline Victor Hugo & 4 & 8 & 0 & 0 & 6 & 0 & 2 & 0 & 0 & 1 \\
\hline Total por proposição & 34 & 104 & 16 & 13 & 12 & 1 & 16 & 2 & 6 & 7 \\
\hline Total por Teoria & & & & & & 11 & & & & \\
\hline
\end{tabular}

As duas proposições da Abordagem sobre Gestão do Conhecimento foram verificadas nas entrevistas. A proposição CO 1 - o conhecimento resulta do compartilhamento de experiências entre os membros da organização - participou em todas as entrevistas: Morana (7), Chilli Beans (6), O Boticário (6), Lilica Ripilica (5), Arezzo (4), Mundo Verde (4), Carmen Steffens (4), Nobel (3), Spoleto (3) e Victor Hugo (2). A proposição CO 2 - o conhecimento resulta do compartilhamento da aprendizagem entre os membros da organização - não foi identificado apenas nas entrevistas do Mundo Verde e Spoleto: Morana (6), O Boticário (3), Chilli Beans (3), Arezzo (3), Lilica Ripilica (3), Carmen Steffens (3), Victor Hugo (1) e Nobel (1).

Foram verificados trechos relacionados a quatro proposições das sete proposições que fazem parte da Abordagem sobre Gestão de Competências. A proposição GC 1 - a empresa tem a capacidade de aprender com o ambiente - apresentou trechos nas entrevistas da Morana (3), Lilica Ripilica (1) e Carmem Steffens (1). A proposição GC 2 - a empresa tem a capacidade de desenvolver estratégias - foi identificada na Arezzo (2), Morana (1) e Chilli Beans (1). A 
proposição GC 3 - a empresa tem a capacidade de disponibilizar as funções de operações apresentou registros em nove empresas, com exceção da Victor Hugo: Mundo Verde (10), Arezzo (8), Lilica Ripilica (6), Carmen Steffens (6), O Boticário (3), Chilli Beans (3), Nobel (3), Spoleto (3) e Morana (1). A proposição GC 4 - a empresa tem a capacidade de disponibilizar a função de desenvolvimento de produto - apenas participou com um trecho na entrevista da Carmen Steffens.

Tabela 3 - Freqüência das proposições por entrevista: $3^{\text {a }}$ parte

\begin{tabular}{|c|c|c|c|c|c|c|c|c|c|c|c|c|}
\hline \multirow{2}{*}{ Empresa } & \multicolumn{1}{c|}{$\begin{array}{c}\text { Escola } \\
\text { Nórdica }\end{array}$} & \multicolumn{4}{|c|}{ Competição e } & \multicolumn{3}{c|}{ Gestão Estratégica } \\
& EN 1 & EN 2 & CC 1 & CC 2 & CC 3 & CC 4 & CC 5 & CC 6 & EO 1 & EO 2 & EO 3 & EO 4 \\
\hline Arezzo & 0 & 0 & 0 & 0 & 1 & 0 & 23 & 31 & 0 & 2 & 0 & 0 \\
\hline Carmen Steffens & 1 & 1 & 0 & 2 & 5 & 3 & 11 & 29 & 2 & 3 & 0 & 0 \\
\hline Chilli Beans & 0 & 0 & 1 & 0 & 2 & 2 & 10 & 32 & 0 & 5 & 0 & 0 \\
\hline Lilica Ripilica & 1 & 0 & 1 & 7 & 2 & 2 & 11 & 29 & 3 & 6 & 1 & 6 \\
\hline Morana & 2 & 0 & 1 & 0 & 4 & 1 & 18 & 14 & 3 & 4 & 0 & 0 \\
\hline Mundo Verde & 0 & 0 & 1 & 2 & 1 & 1 & 21 & 7 & 2 & 8 & 0 & 0 \\
\hline Nobel & 1 & 1 & 1 & 1 & 1 & 0 & 9 & 15 & 0 & 1 & 0 & 4 \\
\hline O Boticário & 0 & 0 & 1 & 2 & 0 & 1 & 7 & 20 & 1 & 1 & 0 & 0 \\
\hline Spoleto & 0 & 0 & 0 & 0 & 0 & 1 & 8 & 20 & 1 & 3 & 0 & 12 \\
\hline Victor Hugo & 2 & 0 & 1 & 3 & 7 & 8 & 3 & 24 & 4 & 4 & 0 & 2 \\
\hline Total por proposição & 7 & 2 & 7 & 17 & 23 & 19 & 121 & 221 & 16 & 37 & 1 & 24 \\
\hline Total por Teoria & 9 & & & 408 & & & & 78 & \\
\hline
\end{tabular}

O Paradigma Eclético participou com cinco de suas nove proposições. A proposição PE 1 - a firma possui vantagem especifica de propriedade de marcas - apresenta registros nas entrevistas da Victor Hugo (9), Nobel (3), Carmen Steffens (3), Chilli Beans (2), Mundo Verde (2) e Lilica Ripilica (1). A empresa Arezzo, O Boticário e Spoleto não apresentaram nenhuma incidência de proposições do Paradigma Eclético. A proposição PE 3 - a firma possui vantagem especifica de propriedade da qualificação da mão-de-obra - aparece na entrevista da Chilli Beans e Arezzo (1). A proposição PE 6 - a firma possui vantagem especifica de localização de mão-de-obra - foi identificada na empresa Victor Hugo apenas (2). A proposição PE 7 - a firma possui vantagem especifica de localização de infra-estrutura - foi apresentada pela Victor Hugo (1). A proposição PE 8 - a firma possui vantagem especifica de localização de mercado - foi mencionada pela Victor Hugo (8), Morana (3), Chilli Beans (2), Lilica Ripilica (2) e Arezzo (1). 
Tabela 4 - Freqüência das proposições por entrevista: $4^{\text {a }}$ parte

\begin{tabular}{|c|c|c|c|c|c|c|c|c|}
\hline \multirow{2}{*}{ Empresa } & \multicolumn{4}{|c|}{$\begin{array}{c}\text { Gestão de } \\
\text { Competências }\end{array}$} & \multicolumn{2}{c|}{$\begin{array}{c}\text { Gestão do } \\
\text { Conhecimento }\end{array}$} & \multicolumn{2}{c|}{$\begin{array}{c}\text { Abordagem } \\
\text { Intercultural }\end{array}$} \\
\cline { 2 - 11 } & GC 1 & GC 2 & GC 3 & GC 4 & CO 1 & CO 2 & AI 1 & AI 5 \\
\hline Arezzo & 0 & 2 & 8 & 0 & 4 & 3 & 0 & 0 \\
\hline Carmen Steffens & 1 & 0 & 6 & 1 & 4 & 3 & 0 & 0 \\
\hline Chilli Beans & 0 & 1 & 3 & 0 & 6 & 3 & 1 & 2 \\
\hline Lilica Ripilica & 1 & 0 & 6 & 0 & 5 & 3 & 0 & 1 \\
\hline Morana & 3 & 1 & 1 & 0 & 7 & 6 & 1 & 0 \\
\hline Mundo Verde & 0 & 0 & 10 & 0 & 4 & 0 & 0 & 1 \\
\hline Nobel & 0 & 0 & 3 & 0 & 3 & 1 & 0 & 0 \\
\hline O Boticário & 0 & 0 & 3 & 0 & 6 & 3 & 0 & 2 \\
\hline Spoleto & 0 & 0 & 3 & 0 & 3 & 0 & 0 & 0 \\
\hline Victor Hugo & 0 & 0 & 0 & 0 & 2 & 1 & 1 & 1 \\
\hline Total por proposição & 5 & 4 & 43 & 1 & 44 & 23 & 3 & 7 \\
\hline Total por Teoria & & 53 & & 67 & & 10 \\
\hline
\end{tabular}

Foram identificados trechos relacionados a três proposições da Teoria de Poder de Mercado de um total de oito proposições. A proposição PM 1 - a empresa reduz a competição em países estrangeiros por meio de conluios ou fusões - foi indicada pelo Spoleto (4) e pela Nobel (1). A proposição PM 2 - a empresa controla outras empresas em países estrangeiros para usar o acesso aos fatores de produção (vantagem única) - aparece para o Spoleto (2). E a proposição PM 7 - a combinação de recursos gerenciais da firma cria novos mercados - foi identificada para Victor Hugo (2), Morana (2), Arezzo, O Boticário, Nobel, Spoleto, Carmen Steffens todas com apenas uma ocorrência. Em duas empresas, Chilli Beans e Mundo Verde, não foi verificado registro de trecho relacionado a esta teoria.

Identificaram-se trechos de entrevistas para três das cinco categorias de proposição da Teoria de Internalização. A proposição IN 3 - a firma integra a produção quando a especificidade dos ativos for grande - foi percebida para Victor Hugo e Spoleto ambas com uma ocorrência. A proposição IN 4 - a firma integra a produção para vencer barreiras de entrada - aparece para Lilica Ripilica (2) e Victor Hugo e Morana (1). A proposição IN 5 - a firma integra a produção quando há incertezas de mercado - foi verificada para Morana (3), Victor Hugo e também Morana (1 registro em ambos os casos). 
A Abordagem Intercultural participou com duas proposições do seu total de cinco. A proposição AI 1 - a cultura de um país ou região interfere na cultura da organização - foi identificado um trecho em cada uma das entrevistas da Victor Hugo, Morana e Chilli Beans. A proposição AI 5 - os padrões de comportamento de um grupo influenciam a gestão da empresa - apresentou registros nas entrevistas da Chilli Beans (2), O Boticário (2), Victor Hugo (1), Mundo Verde (1) e Lilica Ripilica (1).

A Escola Nórdica participou com quatro de cinco proposições que a representam. A proposição EN 1 - o empreendedor (indivíduo) é o responsável pelo desenvolvimento de novos mercados - participou com trechos na entrevista da Morana (2), Victor Hugo (2), Lilica Ripilica (1) e Nobel (1). A proposição EN 2 - o indivíduo emprega sua rede de relacionamentos em novos mercados - foi identificada na Nobel e Carmen Steffens com um registro para cada uma das empresas. A proposição EN 3 - o empreendedor técnico volta-se para produção e processos - apresentou apenas uma ocorrência na Morana. A proposição EN 4 - o empreendedor de marketing volta-se para clientes e mercados - apresentou apenas um trecho na entrevista da Victor Hugo.

A Teoria do Ciclo do Produto apresentou trechos de entrevistas categorizados para quatro proposições, sendo que possui quatorze no total. Essa teoria aborda a questão do ciclo de produto que para o caso do varejo considerou-se o tipo de loja como um produto já que entrega um serviço e um mix de bens específico. A proposição CP 4 - a fase de introdução do produto é marcada pelo desenvolvimento de mercado - foi identificada na Nobel (1). A proposição CP 6 - a fase de crescimento do produto espalha a produção pelos países desenvolvidos - aparece para O Boticário (4) e Morana (1). A proposição CP7 - a fase de crescimento do produto é marcada pela demanda estrangeira - apresentou um único registro na entrevista da Victor Hugo. A proposição CP 8 - a fase de crescimento do produto inicia a difusão da tecnologia - foi verificada apenas na Lilica Ripilica (1). 


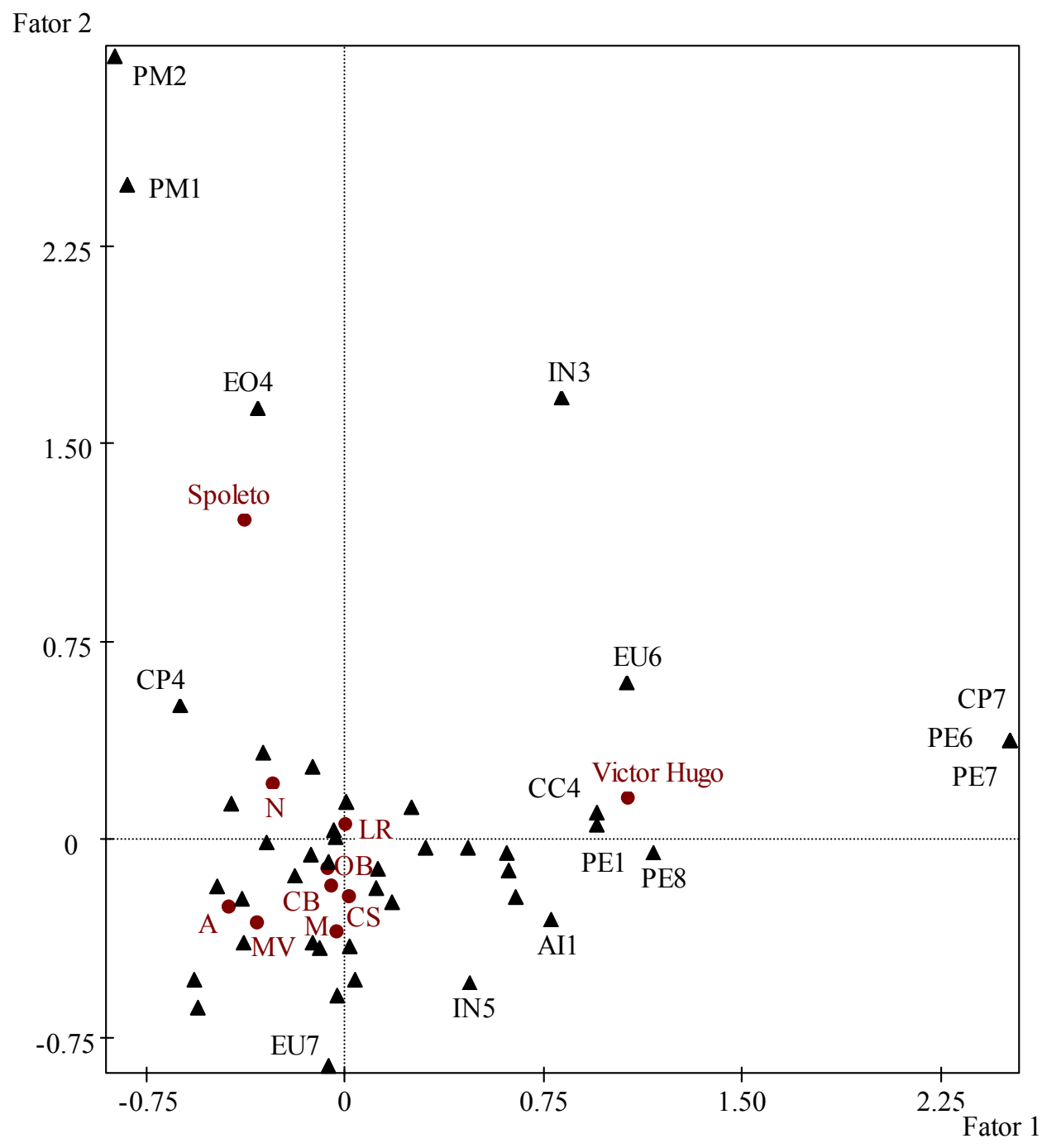

Gráfico 1 - Análise de Correspondência por proposição e por empresa

O Gráfico 2 traz a região de maior concentração dos pontos do Gráfico 1, correspondendo a uma imagem ampliada dessa área. A inércia associada ao Gráfico 1 é de 45,73\%. Porém, nenhuma das proposições deixa de contribuir para a construção dos dois eixos, o que é importante para considerar a análise representativa. 
Fator 2

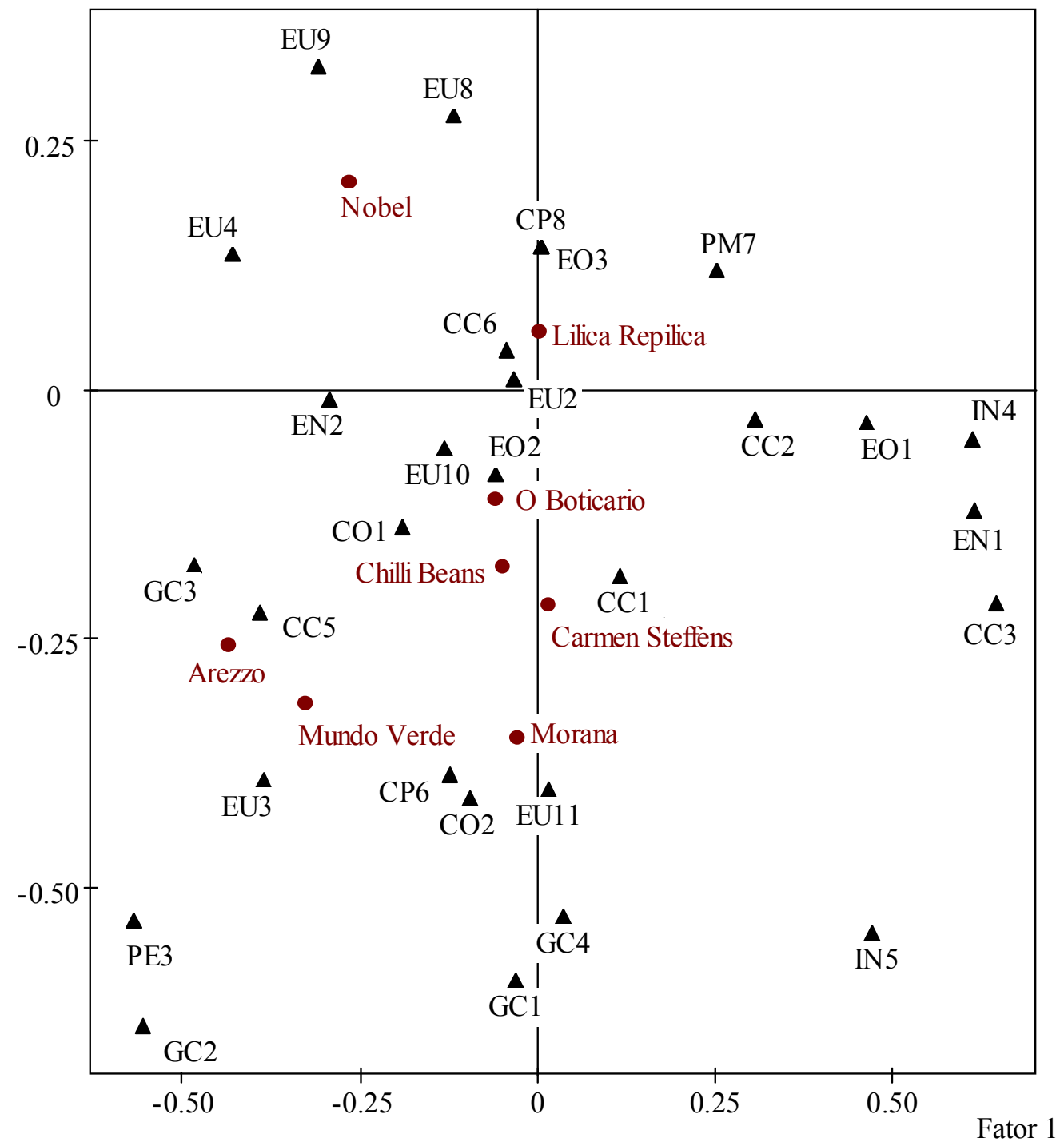

Gráfico 2 - Imagem ampliada da região de maior concentração de pontos do Gráfico 1

\subsubsection{Análise dos dados por proposição e por empresa: por que sair}

As Tabelas 5 e 6 apresentam as freqüências por proposição e por entrevista, focalizando as razões que levaram as empresas estudadas a se internacionalizar. O Gráfico 3, resultante da Análise de Correspondência, mostra espacialmente esse arranjo. Foram identificadas oito teorias nos discursos dos entrevistados. A Teoria de Internacionalização, a Abordagem sobre Gestão Estratégica de Operações e a Abordagem sobre Gestão de Competências não foram reconhecidas. A maior participação em termos do número de trechos foi a da Teoria sobre Competição e Competitividade Global, com 68 ocorrências. Em seqüência, foi identificado o Paradigma Eclético (8), a Teoria do Poder de Mercado (7), Abordagem de Gestão do 
Conhecimento (6), Escola Nórdica (2), Teoria do Ciclo do Produto (2) e Abordagem Intercultural (1).

Tabela 5 - Freqüência das proposições por entrevista: por que sair $-1^{\mathrm{a}}$ parte

\begin{tabular}{|c|c|c|c|c|c|c|c|c|c|}
\hline \multirow[t]{2}{*}{ Empresa } & \multirow{2}{*}{\begin{tabular}{|c|}
$\begin{array}{l}\text { Poder de } \\
\text { Mercado }\end{array}$ \\
PM 7 \\
\end{tabular}} & \multicolumn{2}{|c|}{ Ciclo do Produto } & \multicolumn{3}{|c|}{ Paradigma Eclético } & \multicolumn{2}{|c|}{ Escola de Uppsala } & \multirow{2}{*}{$\begin{array}{c}\begin{array}{c}\text { Escola } \\
\text { Nórdica }\end{array} \\
\text { EN } 1\end{array}$} \\
\hline & & $\mathrm{CP} 4$ & CP 6 & PE 1 & PE 3 & PE 8 & EU 3 & EU 4 & \\
\hline Arezzo & 0 & 0 & 0 & 0 & 1 & 1 & 0 & 0 & 0 \\
\hline Carmen Steffens & 1 & 0 & 0 & 1 & 0 & 0 & 1 & 0 & 1 \\
\hline Chilli Beans & 0 & 0 & 0 & 0 & 0 & 0 & 0 & 0 & 0 \\
\hline Lilica Ripilica & 0 & 0 & 0 & 1 & 0 & 0 & 0 & 0 & 0 \\
\hline Morana & 2 & 0 & 1 & 0 & 0 & 0 & 1 & 0 & 0 \\
\hline Mundo Verde & 0 & 0 & 0 & 0 & 0 & 0 & 0 & 0 & 0 \\
\hline Nobel & 1 & 1 & 0 & 1 & 0 & 0 & 0 & 0 & 1 \\
\hline O Boticário & 1 & 0 & 0 & 0 & 0 & 0 & 0 & 1 & 0 \\
\hline Spoleto & 0 & 0 & 0 & 0 & 0 & 0 & 0 & 0 & 0 \\
\hline Victor Hugo & 2 & 0 & 0 & 3 & 0 & 0 & 0 & 0 & 1 \\
\hline Total por proposição & 7 & 1 & 1 & 6 & 1 & 1 & 2 & 1 & 3 \\
\hline Total por Teoria & 7 & & & & 8 & & & & 3 \\
\hline
\end{tabular}

A Abordagem sobre Competição de Competitividade Global se destacou como principal teoria a ser percebida nas entrevistas. Não se reconheceu trechos de uma única proposição. A proposição CC 1 - a empresa determina a sua estratégia em função da excelência operacional - foi identificada no O Boticário (1) e Nobel (1). A proposição CC 3 - a empresa define sua estratégia pela análise de concorrentes - foi reconhecida na Victor Hugo (2), Morana (1), Lilica Ripilica (1) e Carmen Steffens (1). A proposição CC 4 - a empresa define sua estratégia pela análise de consumidores - foi detectada na Morana (1), Mundo Verde (1) e Carmen Steffens (1). A maior participação de trechos refere-se a proposição CC 5 - a empresa determina sua estratégia pela análise de oportunidades - que foi verificada em todas as empresas: Morana (11), Carmen Steffens (6), Arezzo (5), Mundo Verde (4), Chilli Beans (3), O Boticário (3), Nobel (2), Victor Hugo (1), Lilica Ripilica (1) e Spoleto (1). A proposição CC 6 - a empresa define seu posicionamento estratégico para atuar em novo local apresentou a segunda maior quantidade de trechos: Arezzo (5), Carmen Steffens (5), Lilica Ripilica (4), Victor Hugo (3), O Boticário (2), Morana (1) e Spoleto (1).

O Paradigma Eclético participou com três proposições, sendo que possui nove proposições. A proposição PE 1 - a firma possui vantagem especifica de propriedade de marcas - apresentou 
ocorrência na Victor Hugo (3), Lilica Ripilica (1), Nobel (1) e Carmen Steffens (1). A proposição PE 3 - a firma possui vantagem especifica de propriedade da qualificação da mãode-obra - e a proposição PE 8 - a firma possui vantagem especifica de localização de mercado - foi identificado apenas um trecho para cada uma destas proposições na Arezzo.

Tabela 6 - Freqüência das proposições por entrevista: por que sair - $2^{\mathrm{a}}$ parte

\begin{tabular}{|c|c|c|c|c|c|c|c|c|}
\hline \multirow{2}{*}{ Empresa } & \multicolumn{5}{|c|}{ Competição e } & \multicolumn{2}{c|}{$\begin{array}{c}\text { Gestão do } \\
\text { Conhecimento }\end{array}$} & $\begin{array}{c}\text { Abordagem } \\
\text { Intercultural }\end{array}$ \\
\cline { 2 - 11 } & CC 1 & CC 3 & CC 4 & CC 5 & CC 6 & CO 1 & CO 2 & AI 1 \\
\hline Arezzo & 0 & 0 & 0 & 5 & 5 & 0 & 0 & 0 \\
\hline Carmen Steffens & 0 & 1 & 1 & 6 & 5 & 0 & 0 & 0 \\
\hline Chilli Beans & 0 & 0 & 0 & 3 & 0 & 1 & 1 & 0 \\
\hline Lilica Ripilica & 0 & 1 & 0 & 1 & 4 & 0 & 0 & 0 \\
\hline Morana & 0 & 1 & 1 & 11 & 1 & 2 & 2 & 1 \\
\hline Mundo Verde & 0 & 0 & 1 & 4 & 0 & 0 & 0 & 0 \\
\hline Nobel & 1 & 0 & 0 & 2 & 0 & 0 & 0 & 0 \\
\hline O Boticário & 1 & 0 & 0 & 3 & 2 & 0 & 0 & 0 \\
\hline Spoleto & 0 & 0 & 0 & 1 & 1 & 0 & 0 & 0 \\
\hline Victor Hugo & 0 & 2 & 0 & 1 & 3 & 0 & 0 & 0 \\
\hline Total por proposição & 2 & 5 & 3 & 37 & 21 & 3 & 3 & 1 \\
\hline Total por Teoria & & & 68 & & & 6 & 1 \\
\hline
\end{tabular}

A proposição da Teoria do Poder de Mercado que incidiu sobre as entrevistas foi apenas a PM 7 - a combinação de recursos gerenciais da firma cria novos mercados - nas empresas Victor Hugo (2), Morana (2), O Boticário (1), Nobel (1) e Carmen Steffens (1). O total de proposições desta teoria são oito.

A Abordagem sobre Gestão do Conhecimento apresentou trechos nas suas duas proposições. A proposição CO 1 - o conhecimento resulta do compartilhamento de experiências entre os membros da organização - e a proposição $\mathrm{CO} 2$ - o conhecimento resulta do compartilhamento da aprendizagem entre os membros da organização - foram identificadas nas entrevistas da Morana (2) e Chilli Beans (1) para cada proposição.

Apenas uma proposição da Escola Nórdica foi verificada. Esta teoria possui cinco proposições. A proposição que incidiu sobre as entrevistas foi a EN 1 - o empreendedor (indivíduo) é o responsável pelo desenvolvimento de novos mercados - na Victor Hugo (1), Nobel (1) e Carmen Steffens (1). 
A Escola de Uppsala participou com duas de suas 12 proposições. A proposição EU 3 - a cultura em determinado local interfere no processo de expansão da empresa - incidiu na entrevista da Carmen Steffens (1) e da Morana (1). A proposição EU 4 - o idioma em determinado local interfere no processo de expansão da empresa - foi detectada apenas uma vez, no discurso do entrevistado de O Boticário.

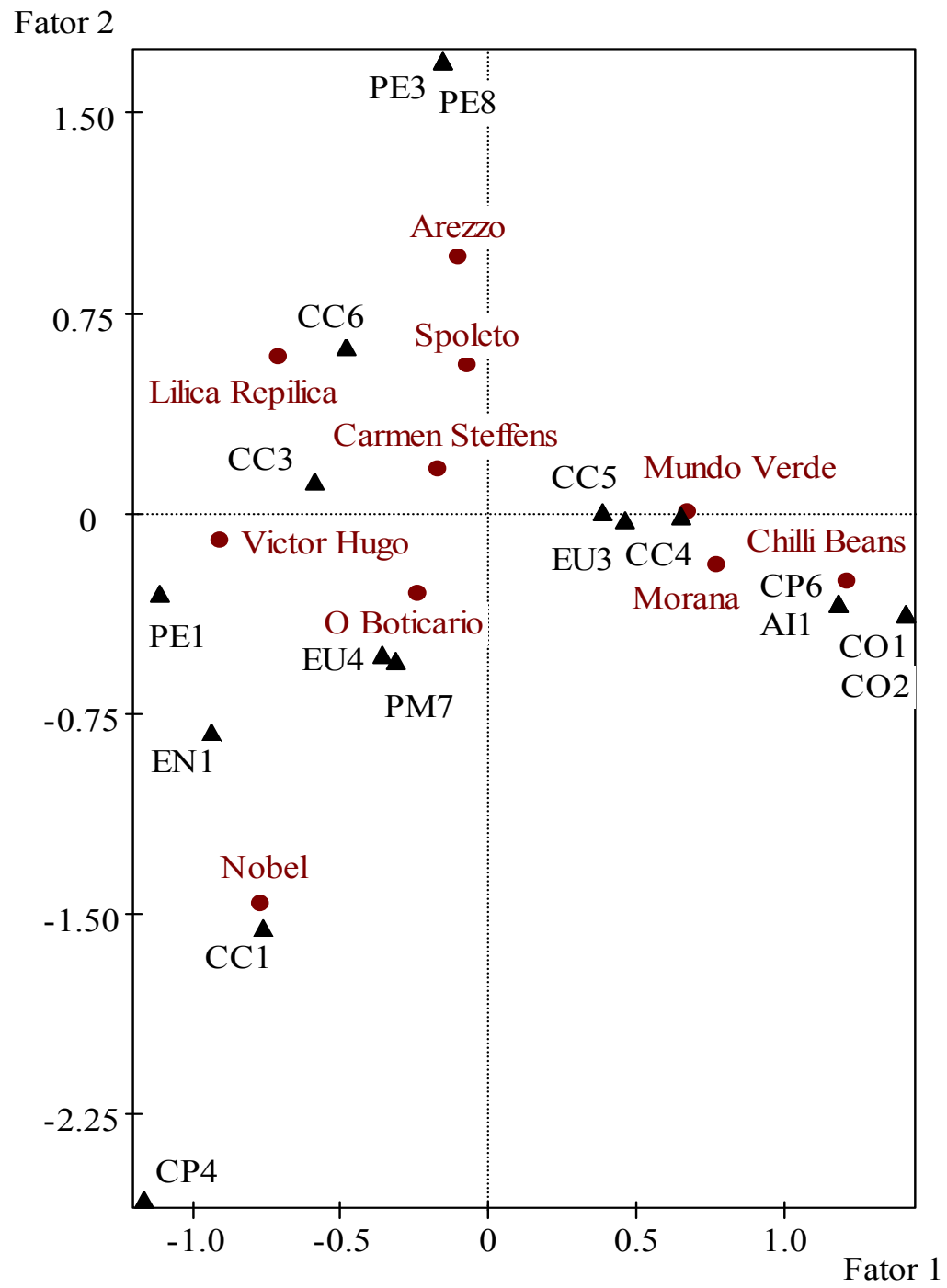

\section{Gráfico 3 - Análise de Correspondência por proposição e por empresa: por que sair}

A Teoria do Ciclo do Produto apresentou trechos para duas de suas 14 proposições. A proposição CP 4 - a fase de introdução do produto é marcada pelo desenvolvimento de mercado - foi percebida na Nobel (1) e a proposição CP 6 - a fase de crescimento do produto espalha a produção pelos países desenvolvidos - ocorreu na Morana (1). 
Uma única proposição da Abordagem Intercultural foi reconhecida nas entrevistas. A proposição AI 1 - a cultura de um país ou região interfere na cultura da organização apareceu apenas uma vez, no discurso do entrevistado da Morana.

O Gráfico 3 mostra a Análise de Correspondência relativa às razões que levaram as empresas a se internacionalizar (por que sair). A inércia associada ao Gráfico 3 é de 54,06\% e todas as proposições tiveram contribuição na construção dos dois eixos.

\subsubsection{Análise dos dados por proposição e por empresa: para onde ir}

As Tabelas 7 e 8 mostram a quantidade de trechos por proposição que se relacionam com a escolha do país estrangeiro e as razões que levam a essa escolha. O Gráfico 4 ilustra essa distribuição por meio da Análise de Correspondência. Há quatro teorias que não foram identificadas nas entrevistas: Teoria da Internalização, Abordagem sobre Gestão de Competências, Abordagem sobre Gestão do Conhecimento e Abordagem Intercultural. A maior incidência de trechos aconteceu para a Teoria sobre Competição e Competitividade Global, que apresentou 156 registros. Em ordem decrescente vieram a seguir a Escola de Uppsala, com 35 registros; o Paradigma Eclético, com 25; a Abordagem sobre Gestão Estratégica de Operações, com três; a Escola Nórdica, com dois; e tanto a Teoria do Poder de Mercado quanto a Teoria do Ciclo do Produto, com uma única ocorrência para cada.

Tabela 7 - Freqüência das proposições por entrevista: para onde ir $-1^{a}$ parte

\begin{tabular}{|c|c|c|c|c|c|c|c|c|c|c|c|c|c|}
\hline \multirow[t]{2}{*}{ Empresa } & \multirow{2}{*}{$\begin{array}{c}\begin{array}{c}\text { Poder de } \\
\text { Mercado }\end{array} \\
\text { PM } 7 \\
\end{array}$} & \multirow{2}{*}{$\begin{array}{c}\begin{array}{c}\text { Ciclo do } \\
\text { Produto }\end{array} \\
\text { CP } 7 \\
\end{array}$} & \multicolumn{4}{|c|}{$\begin{array}{l}\text { Paradigma } \\
\text { Eclético }\end{array}$} & \multicolumn{7}{|c|}{$\begin{array}{c}\text { Escola de } \\
\text { Uppsala }\end{array}$} \\
\hline & & & PE 1 & PE 6 & PE 7 & PE 8 & EU 1 & EU 2 & EU 3 & EU 4 & EU 8 & EU 9 & EU 10 \\
\hline Arezzo & 1 & 0 & 0 & 0 & 0 & 0 & 0 & 1 & 2 & 2 & 0 & 0 & 0 \\
\hline Carmen Steffens & 0 & 0 & 2 & 0 & 0 & 0 & 0 & 1 & 1 & 1 & 0 & 0 & 0 \\
\hline Chilli Beans & 0 & 0 & 1 & 0 & 0 & 2 & 0 & 2 & 0 & 0 & 0 & 0 & 0 \\
\hline Lilica Ripilica & 0 & 0 & 0 & 0 & 0 & 1 & 1 & 2 & 0 & 0 & 1 & 0 & 0 \\
\hline Morana & 0 & 0 & 0 & 0 & 0 & 3 & 0 & 1 & 1 & 2 & 0 & 0 & 1 \\
\hline Mundo Verde & 0 & 0 & 2 & 0 & 0 & 0 & 1 & 1 & 1 & 0 & 1 & 0 & 0 \\
\hline Nobel & 0 & 0 & 0 & 0 & 0 & 0 & 0 & 0 & 3 & 2 & 0 & 1 & 0 \\
\hline O Boticário & 0 & 0 & 0 & 0 & 0 & 0 & 0 & 1 & 0 & 1 & 0 & 0 & 0 \\
\hline Spoleto & 0 & 0 & 0 & 0 & 0 & 0 & 0 & 0 & 0 & 2 & 0 & 0 & 0 \\
\hline Victor Hugo & 0 & 1 & 3 & 2 & 1 & 8 & 1 & 0 & 0 & 0 & 1 & 0 & 0 \\
\hline $\begin{array}{c}\text { Total por } \\
\text { proposição }\end{array}$ & 1 & 1 & 8 & 2 & 1 & 14 & 3 & 9 & 8 & 10 & 3 & 1 & 1 \\
\hline Total por Teoria & 1 & 1 & \multicolumn{4}{|c|}{25} & \multicolumn{7}{|c|}{35} \\
\hline
\end{tabular}


Tabela 8 - Freqüência das proposições por entrevista: para onde ir $-2^{a}$ parte

\begin{tabular}{|c|c|c|c|c|c|c|c|c|c|}
\hline \multirow{2}{*}{ Empresa } & $\begin{array}{c}\text { Escola } \\
\text { Nórdica }\end{array}$ & \multicolumn{5}{|c|}{ Competição e } & \multicolumn{2}{c|}{$\begin{array}{c}\text { Gestão Estratégia de } \\
\text { Operações }\end{array}$} \\
\cline { 2 - 13 } & EN 1 & CC 1 & CC 2 & CC 3 & CC 4 & CC 5 & CC 6 & EO 2 & EO 4 \\
\hline Arezzo & 0 & 0 & 0 & 1 & 0 & 13 & 7 & 0 & 0 \\
\hline Carmen Steffens & 0 & 0 & 1 & 2 & 0 & 4 & 9 & 0 & 0 \\
\hline Chilli Beans & 0 & 1 & 0 & 2 & 0 & 1 & 15 & 0 & 0 \\
\hline Lilica Ripilica & 0 & 0 & 3 & 1 & 1 & 6 & 7 & 0 & 0 \\
\hline Morana & 1 & 1 & 0 & 2 & 0 & 6 & 6 & 0 & 0 \\
\hline Mundo Verde & 0 & 0 & 0 & 0 & 0 & 12 & 5 & 0 & 0 \\
\hline Nobel & 0 & 0 & 1 & 1 & 0 & 4 & 4 & 0 & 1 \\
\hline O Boticário & 0 & 0 & 1 & 0 & 1 & 1 & 5 & 0 & 0 \\
\hline Spoleto & 0 & 0 & 0 & 0 & 0 & 0 & 2 & 1 & 1 \\
\hline Victor Hugo & 1 & 1 & 3 & 5 & 8 & 1 & 12 & 0 & 0 \\
\hline Total por proposição & 2 & 3 & 9 & 14 & 10 & 48 & 72 & 1 & 2 \\
\hline Total por Teoria & 2 & & & 156 & & & & 3 \\
\hline
\end{tabular}

Todas as seis proposições da Teoria sobre Competição e Competitividade Global foram identificadas nos discursos dos entrevistados. A proposição CC 1 - a empresa determina a sua estratégia em função da excelência operacional - incidiu nas entrevistas da Victor Hugo, Morana e Chilli Beans uma vez em cada uma delas. A proposição CC 2 - a empresa determina sua estratégia pela análise de produtos - foi identificada naVictor Hugo (3), Lilica Ripilica (3), O Boticário (1), Nobel (1) e Carmen Steffens (1). Duas proposições apresentaram as terceiras maiores participações relacionadas à escolha do país estrangeiro. Um delas foi a proposição CC 3 e a outra PE8. A proposição CC 3 - a empresa define sua estratégia pela análise de concorrentes - foi verificada nas empresas Victor Hugo (5), Morana (2), Chilli Beans (2), Carmen Steffens (2), Arezzo (1), Lilica Ripilica (1) E Nobel (1). Apenas não foi identificada no Mundo Verde e Spoleto. A proposição CC 4 - a empresa define sua estratégia pela análise de consumidores - apresentou registros na Victor Hugo (8), Lilica Ripilica (1) e O Boticário (1). A segunda maior participação de uma proposição foi a CC 5 - a empresa determina sua estratégia pela análise de oportunidades - que apenas foi reconhecida na entrevista da Spoleto. Foi identificada no discurso da Arezzo (13), Mundo Verde (12), Morana (6), Lilica Ripilica (6), Nobel (4), Carmen Steffens (4), Victor Hugo (1), Chilli Beans (1) e O Boticário (1). A proposição que obteve a maior incidência de trechos foi CC 6 - a empresa define seu posicionamento estratégico para atuar em novo local - com trechos localizados em todas as entrevistas: Chilli Beans (15), Victor Hugo (12), Carmen Steffens (9), 
Arezzo (7), Lilica Ripilica (7), Morana (6), Mundo Verde (5), O Boticário (5), Nobel (4) e Spoleto (2).

A Escola de Uppsala participou com sete de suas doze proposições. A proposição EU 1 - a firma internacionaliza por meio de um processo gradual - foi identificada em três empresas, Victor Hugo, Mundo Verde e Lilica Ripilica, com um trecho em cada uma delas. A proposição EU 2 - a firma adquire gradativamente conhecimento do local para o qual pretende se deslocar (aprendizagem) - incidiu na Chilli Beans (2), Lilica Ripilica (2), Morana (1), Arezzo (1), Mundo Verde (1), O Boticário (1) e Carmen Steffens (1). A proposição EU 3 - a cultura em determinado local interfere no processo de expansão da empresa - apareceu na Nobel (3), Arezzo (2), Morana (1), Mundo Verde (1) e Carmen Steffens (1). A proposição EU 4 - o idioma em determinado local interfere no processo de expansão da empresa - foi verificado nos discursos dos entrevistados da Morana (2), Arezzo (2), Nobel (2), Spoleto (2), O Boticário (1) e Carmen Steffens (1). A proposição EU 8 - o relacionamento com os clientes em determinado local interfere no processo de expansão da empresa - incidiu na Victor Hugo (1), Mundo Verde (1) e Lilica Ripilica (1). Houve apenas um trecho da entrevista da Nobel que foi atribuído para a proposição EU 9 - o relacionamento com os fornecedores em determinado local interfere no processo de expansão da empresa. O mesmo aconteceu para a proposição EU 10 - o relacionamento com os distribuidores em determinado local interfere no processo de expansão da empresa - que apresentou um trecho na entrevista da Morana.

O Paradigma Eclético participou com quatro proposições de um total de nove proposições. A proposição PE1 - a firma possui vantagem especifica de propriedade de marcas - foi identificada para Victor Hugo (3), Mundo Verde (2), Carmen Steffens (2) e Chilli Beans (1). A proposição PM6 - a firma possui vantagem especifica de localização de mão-de-obra - foi percebida apenas na entrevista da Victor Hugo (2). A proposição PE7 - a firma possui vantagem especifica de localização de infra-estrutura - incidiu apenas uma vez na empresa Victor Hugo. A terceira maior participação de uma proposição relacionada aos motivos que levaram a internacionalização das empresas estudadas foi a proposição PE8 - a firma possui vantagem especifica de localização de mercado. Foram 8 trechos na Victor Hugo, 3 na Morana, 2 na Chilli Beans e 1 na Lilica Ripilica.

A Abordagem sobre Gestão Estratégica de Operações apresentou duas de suas seis proposições. A proposição EO 2 - a firma escolhe a estrutura organizacional para atuar no 
mercado em função de suas características internas - foi verificada apenas uma vez, no Spoleto. E a proposição EO 4 - a firma escolhe a estrutura organizacional para atuar no mercado em função de sua rede de relacionamentos internacionais - apareceu nos discursos dos entrevistados da Nobel (1) e Spoleto (1).

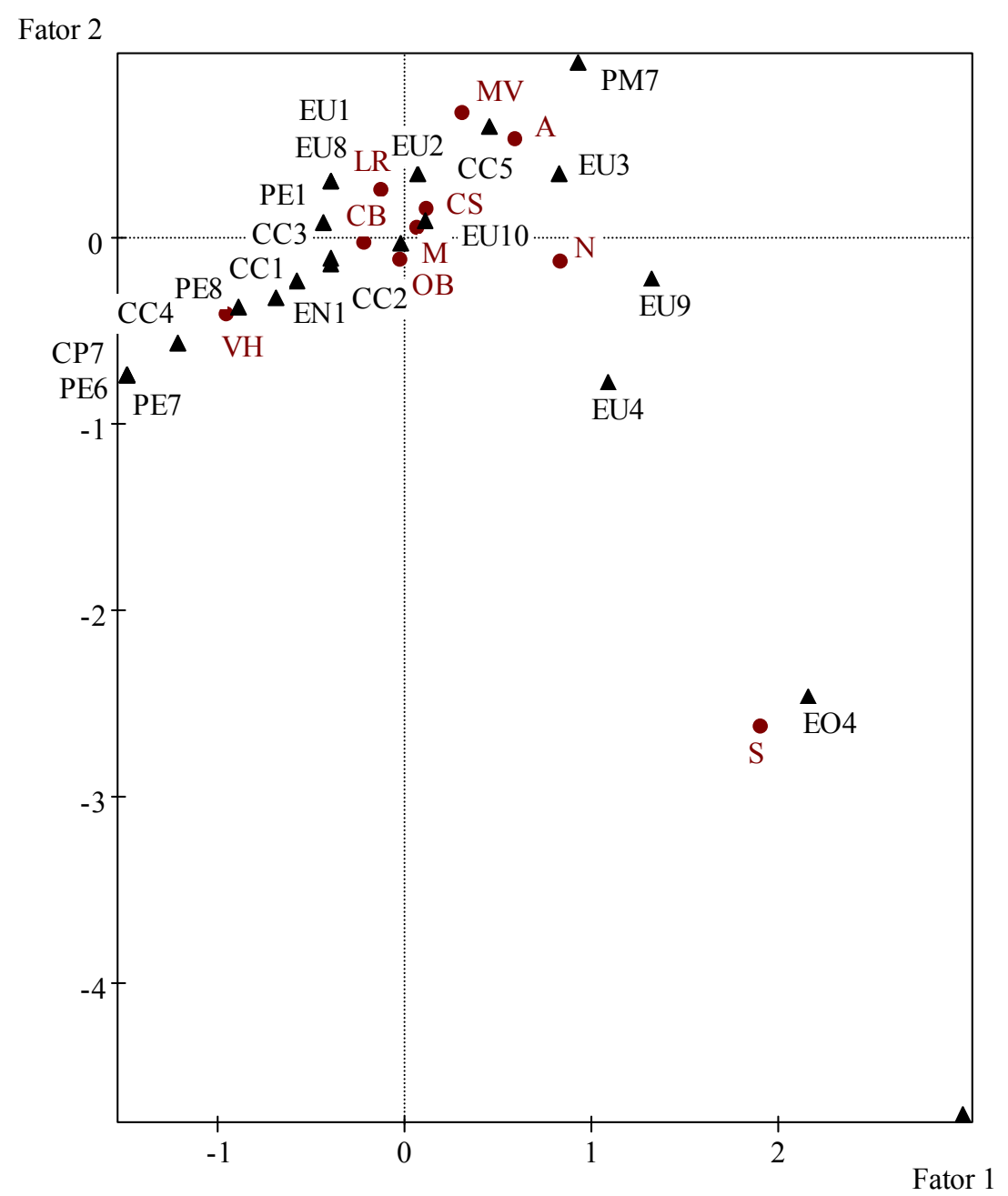

Gráfico 4 - Análise de Correspondência por proposição e por empresa: para onde ir

Dois trechos foram atribuídos a Escola Nórdica. A proposição EN1 - o empreendedor (indivíduo) é o responsável pelo desenvolvimento de novos mercados sendo cada um deles sendo um trecho para Victor Hugo e outro para Morana. A teoria possui cinco proposições.

A Teoria do Poder de Mercado apresentou uma ocorrência para a proposição PM7 combinação de recursos gerenciais da firma cria novos mercados - e foi para a empresa Arezzo. A Teoria do Ciclo do Produto também mostrou um trecho para a empresa Victor Hugo e para a proposição CP7 - a fase de crescimento do produto é marcada pela demanda 
estrangeira. A Teoria do Poder de Mercado possui oito proposições e a Teoria do Ciclo do Produto, quatorze.

A Análise de Correspondência relacionada à investigação do local para onde as empresas se deslocaram e os motivos dessa escolha - para onde ir e por que esse local - encontra-se registrada no Gráfico 4. A inércia associada ao Gráfico 4 é de 59,19\%. Mais uma vez, todas as proposições teóricas tiveram contribuição na construção dos dois eixos.

\subsubsection{Análise dos dados por proposição e por empresa: como entrar no novo local}

Ao analisar a maneira como cada empresa decide iniciar atividade em países estrangeiros, só não foram detectados, no discurso dos entrevistados, trechos relativos à Teoria do Ciclo do Produto (Tabelas de 9 a 12). O resultado da Análise de Correspondência está registrado no Gráfico 5, que apresenta visualmente as distâncias entre proposições e empresas. A Teoria sobre Competição e Competitividade Global apresentou a maior participação, com 136 registros, seguida pela Escola de Uppsala, com 79; Abordagem sobre Gestão Estratégica de Operações, com 29; Abordagem sobre Gestão de Competências, com 16; Abordagem sobre Gestão do Conhecimento, com 12; Teoria de Internalização, com dez; Teoria do Poder de Mercado, com oito; Paradigma Eclético, com sete; Escola Nórdica, com quatro; e Abordagem Intercultural, com apenas uma ocorrência.

Tabela 9 - Freqüência das proposições por entrevista: como entrar no novo local $-1^{a}$ parte

\begin{tabular}{|c|c|c|c|c|c|c|c|c|c|}
\hline \multirow{2}{*}{ Empresa } & \multicolumn{2}{|c|}{ Poder de Mercado } & \multicolumn{2}{|c|}{ Internalização } & \multicolumn{3}{c|}{ Paradigma Eclético } \\
\cline { 2 - 12 } & PM 1 & PM 2 & PM 7 & IN 3 & IN 4 & IN 5 & PE 1 & PE 3 & PE 8 \\
\hline Arezzo & 0 & 0 & 0 & 0 & 0 & 0 & 0 & 0 & 0 \\
\hline Carmen Steffens & 0 & 0 & 0 & 0 & 0 & 1 & 0 & 0 & 0 \\
\hline Chilli Beans & 0 & 0 & 0 & 0 & 0 & 0 & 1 & 1 & 0 \\
\hline Lilica Ripilica & 0 & 0 & 0 & 0 & 2 & 0 & 0 & 0 & 1 \\
\hline Morana & 0 & 0 & 0 & 0 & 1 & 3 & 0 & 0 & 0 \\
\hline Mundo Verde & 0 & 0 & 0 & 0 & 0 & 0 & 0 & 0 & 0 \\
\hline Nobel & 1 & 0 & 0 & 0 & 0 & 0 & 2 & 0 & 0 \\
\hline O Boticário & 0 & 0 & 0 & 0 & 0 & 0 & 0 & 0 & 0 \\
\hline Spoleto & 4 & 2 & 1 & 0 & 0 & 0 & 0 & 0 & 0 \\
\hline Victor Hugo & 0 & 0 & 0 & 1 & 1 & 1 & 2 & 0 & 0 \\
\hline Total por proposição & 5 & 2 & 1 & 1 & 4 & 5 & 5 & 1 & 1 \\
\hline Total por Teoria & & 8 & & & 10 & & & 7 & \\
\hline
\end{tabular}


Tabela 10 - Freqüência das proposições por entrevista: como entrar no novo local $-2^{\mathrm{a}}$ parte

\begin{tabular}{|c|c|c|c|c|c|c|c|c|c|c|}
\hline \multirow{2}{*}{ Empresa } & \multicolumn{9}{|c|}{ Escola de Uppsala } & \multicolumn{3}{c|}{ Escola Nórdica } \\
\cline { 2 - 14 } & EU 1 & EU 2 & EU 3 & EU 4 & EU 7 & EU 8 & EU 10 & EU 11 & EM 1 & EM 2 \\
\hline Arezzo & 3 & 1 & 0 & 0 & 0 & 0 & 0 & 0 & 0 & 0 \\
\hline Carmen Steffens & 5 & 4 & 0 & 0 & 0 & 0 & 0 & 0 & 0 & 1 \\
\hline Chilli Beans & 1 & 4 & 1 & 0 & 0 & 2 & 1 & 0 & 0 & 0 \\
\hline Lilica Ripilica & 10 & 5 & 0 & 0 & 0 & 0 & 3 & 0 & 1 & 0 \\
\hline Morana & 1 & 13 & 1 & 1 & 1 & 2 & 0 & 2 & 1 & 0 \\
\hline Mundo Verde & 0 & 0 & 0 & 0 & 0 & 0 & 0 & 0 & 0 & 0 \\
\hline Nobel & 2 & 4 & 0 & 0 & 0 & 0 & 1 & 1 & 0 & 1 \\
\hline O Boticário & 1 & 3 & 1 & 0 & 0 & 0 & 0 & 0 & 0 & 0 \\
\hline Spoleto & 0 & 2 & 0 & 0 & 0 & 0 & 0 & 0 & 0 & 0 \\
\hline Victor Hugo & 3 & 0 & 0 & 0 & 0 & 0 & 0 & 0 & 0 & 0 \\
\hline Total por proposição & 26 & 36 & 3 & 1 & 1 & 4 & 5 & 3 & 2 & 2 \\
\hline Total por Teoria & & & & & 79 & & & & & 4 \\
\hline
\end{tabular}

Tabela 11 - Freqüência das proposições por entrevista: como entrar no novo local $-3^{\mathrm{a}}$ parte

\begin{tabular}{|c|c|c|c|c|c|c|c|c|c|}
\hline \multirow{2}{*}{ Empresa } & \multicolumn{7}{|c|}{$\begin{array}{c}\text { Competição e } \\
\end{array}$} & \multicolumn{7}{|c|}{ Competitividade Global } & \multicolumn{3}{c|}{ Gestão Estratégica de Operações } \\
\cline { 2 - 12 } & CC 1 & CC 2 & CC 3 & CC 4 & CC 5 & CC 6 & EO 1 & EO 2 & EO 4 \\
\hline Arezzo & 0 & 0 & 0 & 0 & 3 & 17 & 0 & 2 & 0 \\
\hline Carmen Steffens & 0 & 0 & 1 & 1 & 1 & 15 & 0 & 1 & 0 \\
\hline Chilli Beans & 0 & 0 & 0 & 2 & 6 & 14 & 0 & 0 & 0 \\
\hline Lilica Ripilica & 0 & 3 & 0 & 0 & 1 & 14 & 0 & 2 & 6 \\
\hline Morana & 0 & 0 & 1 & 0 & 1 & 7 & 1 & 1 & 0 \\
\hline Mundo Verde & 1 & 0 & 1 & 0 & 0 & 0 & 0 & 5 & 0 \\
\hline Nobel & 0 & 0 & 0 & 0 & 3 & 11 & 0 & 0 & 1 \\
\hline O Boticário & 0 & 0 & 0 & 0 & 2 & 5 & 0 & 0 & 0 \\
\hline Spoleto & 0 & 0 & 0 & 0 & 3 & 14 & 0 & 1 & 7 \\
\hline Victor Hugo & 0 & 0 & 0 & 0 & 1 & 8 & 0 & 0 & 2 \\
\hline Total por proposição & 1 & 3 & 3 & 3 & 21 & 105 & 1 & 12 & 16 \\
\hline Total por Teoria & & & 136 & & & & 29 & \\
\hline
\end{tabular}


Tabela 12 - Freqüência das proposições por entrevista: como entrar no novo local $-4^{\mathrm{a}}$ parte

\begin{tabular}{|c|c|c|c|c|c|}
\hline \multirow{2}{*}{ Empresa } & \multicolumn{2}{|c|}{$\begin{array}{c}\text { Gestão de } \\
\text { Competências }\end{array}$} & \multicolumn{2}{c|}{$\begin{array}{c}\text { Gestão do } \\
\text { Conhecimento }\end{array}$} & $\begin{array}{c}\text { Abordagem } \\
\text { Intercultural }\end{array}$ \\
\cline { 2 - 7 } & GC 2 & GC 3 & CO 1 & CO 2 & AI 5 \\
\hline Arezzo & 2 & 2 & 1 & 1 & 0 \\
\hline Carmen Steffens & 0 & 3 & 3 & 2 & 0 \\
\hline Chilli Beans & 0 & 0 & 0 & 0 & 0 \\
\hline Lilica Ripilica & 0 & 1 & 0 & 0 & 0 \\
\hline Morana & 0 & 0 & 1 & 1 & 0 \\
\hline Mundo Verde & 0 & 5 & 0 & 0 & 0 \\
\hline Nobel & 0 & 1 & 1 & 0 & 0 \\
\hline O Boticário & 0 & 0 & 0 & 0 & 0 \\
\hline Spoleto & 0 & 2 & 2 & 0 & 0 \\
\hline Victor Hugo & 0 & 0 & 0 & 0 & 1 \\
\hline Total por proposição & 2 & 14 & 8 & 4 & 1 \\
\hline Total por Teoria & & & & 12 & 1 \\
\hline
\end{tabular}

A Teoria sobre Competição e Competitividade Global incidiu na maior quantidade de trechos com essa classificação. Todos as suas seis proposições apresentaram registros. A proposição CC 1 - a empresa determina a sua estratégia em função da excelência operacional - incidiu em um trecho da entrevista do Mundo Verde. A proposição CC 2 - a empresa determina sua estratégia pela análise de produtos - foi identificada em três trechos da entrevista da Lilica Ripilica. A proposição CC 3 - a empresa define sua estratégia pela análise de concorrentes foi reconhecida no discurso dos entrevistados da Morana (1), Mundo Verde (1) e Carmen Steffens (1). A proposição CC 4 - a empresa define sua estratégia pela análise de consumidores - foi identificada na Chilli Beans (2) e Carmen Steffens (1). A proposição CC 5 - a empresa determina sua estratégia pela análise de oportunidades - só não foi percebida na empresa Mundo Verde. As demais empresas participaram: Chilli Beans (6), Arezzo (3), Nobel (3), Spoleto (3), O Boticário (2), Victor Hugo (1), Morana (1), Lilica Ripilica (1) e Carmen Steffens (1). A maior participação de proposição relacionada ao modo de saída das empresas pesquisadas foi CC 6 - a empresa define seu posicionamento estratégico para atuar em novo local - que apresentou registros na Arezzo (17), Carmen Steffens (15), Chilli Beans (14), Lilica Ripilica (14), Spoleto (14), Nobel (11), Victor Hugo (8), Morana (7) e O Boticário (5).

Foram identificadas oito entre 12 proposições que fazem parte da Escola de Uppsala. A proposição EU 1 - a firma internacionaliza por meio de um processo gradual - constitui a 
terceira proposição com maior participação quando se analisa o modo que as empresas escolhem para iniciar operação em um país estrangeiro. As empresas que apresentaram trechos dela são a Lilica Ripilica (10), Carmen Steffens (5), Victor Hugo (3), Arezzo (3), Nobel (2), Morana (1), Chilli Beans (1) e O Boticário (1). A segunda maior quantidade de registros é da proposição EU 2 - a firma adquire gradativamente conhecimento do local para o qual pretende se deslocar (aprendizagem) - e as empresas que participaram com trechos de entrevista foram Morana (13), Lilica Ripilica (5), Chilli Beans (4), Nobel (4), Carmen Steffens (4), O Boticário (3), Spoleto (2) e Arezzo (1). A proposição EU 3 - a cultura em determinado local interfere no processo de expansão da empresa - foi percebida na Morana (1), Chilli Beans (1) e O Boticário (1). As proposições EU 4 - o idioma em determinado local interfere no processo de expansão da empresa - e EU 7 - o desenvolvimento do setor em determinado local interfere no processo de expansão da empresa - incidiram na entrevista da Morana com um trecho para cada proposição. A proposição EU 8 - o relacionamento com os clientes em determinado local interfere no processo de expansão da empresa - foi identificada na Morana (2) e Chilli Beans (2). A proposição EU 10 - o relacionamento com os distribuidores em determinado local interfere no processo de expansão da empresa - foi percebida na Lilica Ripilica (3), Chilli Beans (1) e Nobel (1). Por fim, a proposição EU 11 - o relacionamento com as agências reguladoras em determinado local interfere no processo de expansão da empresa - foi identificada na Morana (2) e Nobel (1).

A Abordagem sobre Gestão Estratégica de Operações participou com três de suas seis proposições. A proposição EO 1 - a firma escolhe a estrutura organizacional para atuar no mercado em função das características deste mercado - apresentou apenas um trecho na Morana. A proposição EO 2 - a firma escolhe a estrutura organizacional para atuar no mercado em função de suas características internas - foi identificada na entrevista do Mundo Verde (5), Arezzo (2), Lilica Ripilica (2), Morana (1), Spoleto (1) e Carmen Steffens (1). A proposição EO 4 - a firma escolhe a estrutura organizacional para atuar no mercado em função de sua rede de relacionamentos internacionais - foi percebida no Spoleto (7), Lilica Ripilica (6), Victor Hugo (2) e Nobel (1).

A Abordagem sobre Gestão de Competências apresentou duas proposições de um total de sete. A proposição GC 2 - a empresa tem a capacidade de desenvolver estratégias - participou com dois trechos na entrevista da Arezzo. A proposição GC 3 - a empresa tem a capacidade 
de disponibilizar as funções de operações - foi identificada no Mundo Verde (5), Carmen Steffens (3), Arezzo (2), Spoleto (2), Lilica Ripilica (1) e Nobel (1).

A Abordagem sobre Gestão do Conhecimento participou com suas duas proposições. A proposição CO 1 - o conhecimento resulta do compartilhamento de experiências entre os membros da organização - incidiu nos discursos dos entrevistados da Carmen Steffens (3), Spoleto (2), Morana (1), Arezzo (1) e Nobel (1).

A Teoria de Internalização participou com três de cinco proposições. A proposição IN 3 - a firma integra a produção quando a especificidade dos ativos for grande - foi percebida em um trecho na entrevista da Victor Hugo. A proposição IN 4 - a firma integra a produção para vencer barreiras de entrada - foi identificada na Lilica Ripilica (2), Victor Hugo (1) e Morana (1). A proposição IN 5 - a firma integra a produção quando há incertezas de mercado participou da Morana (3), Victor Hugo (1) e Carmen Steffens (1).

A Teoria do Poder de Mercado apresentou trechos em três de suas oito proposições. A proposição PM 1 - a empresa reduz a competição em países estrangeiros por meio de conluios ou fusões - esta presente nas entrevistas do Spoleto (4) e Nobel (1). A proposição PM 2 - a empresa controla outras empresas em países estrangeiros para usar o acesso aos fatores de produção (vantagem única) - apareceu apenas na empresa Spoleto (2). A proposição PM 7 - a combinação de recursos gerenciais da firma cria novos mercados - foi percebida uma vez no discurso do entrevistado do Spoleto.

O Paradigma Eclético contribui com três proposições de suas nove proposições. A proposição PE 1 - a firma possui vantagem especifica de propriedade de marcas - foi identificada na Victor Hugo (2), Nobel (2) e Chilli Beans (1). A proposição PE 3 - a firma possui vantagem especifica de propriedade da qualificação da mão-de-obra - foi percebida exclusivamente uma vez na Chilli Beans. E a proposição PE 8 - a firma possui vantagem especifica de localização de mercado - foi identificado um trecho na entrevista da Lilica Ripilica.

Identificaram-se duas das cinco proposições da Escola Nórdica. A proposição EN 1 - o empreendedor (indivíduo) é o responsável pelo desenvolvimento de novos mercados - foi identificada na Lilica Ripilica (1) e Morana (1). A proposição EN 2 - o indivíduo emprega 
sua rede de relacionamentos em novos mercados - apresentou registros no discurso dos entrevistados da Carmen Steffens (1) e Nobel (1).

A Abordagem Intercultural participou com uma única proposição dentre as cinco que a compõem. A proposição AI 5 - os padrões de comportamento de um grupo influenciam a gestão da empresa - foi notada apenas uma vez, na Victor Hugo.

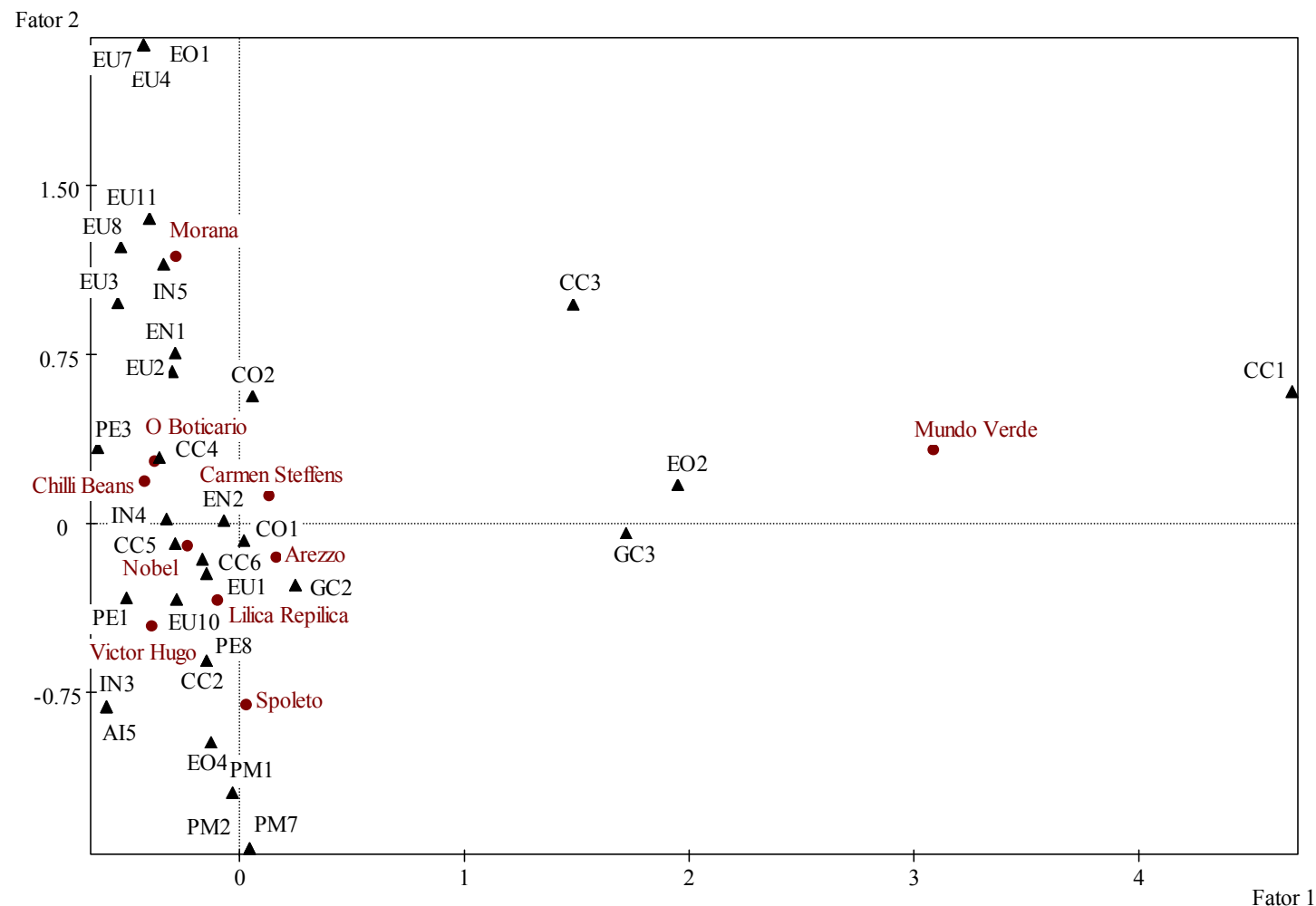

Gráfico 5 - Análise de Correspondência por proposição e por empresa: como entrar no novo local

O Gráfico 5 apresenta a Análise de Correspondência para a escolha do modelo de operação no momento de entrada no novo país - como entrar. A inércia associada ao Gráfico 5 é de $47,13 \%$. Todas as proposições tiveram contribuição na construção dois eixos representados no gráfico. 


\subsubsection{Análise dos dados por proposição e por empresa: como se adaptar ao novo local}

As Tabelas de 13 a 15 apresentam a freqüência dos trechos que abordam a maneira como as empresas estudadas se adaptaram aos locais internacionais onde estabeleceram operação. $\mathrm{O}$ Gráfico 6 demonstra, por meio de mapa perceptual, essa organização. Não foram identificados trechos relacionados à Teoria do Poder de Mercado e à Escola Nórdica. A estrutura teórica que obteve a maior participação em quantidade de registros foi a Escola de Uppsala, com 94 ocorrências. Em seqüência, verifica-se a Abordagem sobre Gestão do Conhecimento, com 49 registros; a Teoria sobre Competição e Competitividade Global, com 48; a Abordagem sobre Gestão Estratégica de Operações, com 46; a Abordagem sobre Gestão de Competências, com 37; a Abordagem Intercultural, com oito; a Teoria do Ciclo do Produto, com cinco; e, com uma ocorrência em cada, a Teoria de Internalização e o Paradigma Eclético.

Tabela 13 - Freqüência das proposições por entrevista: como se adaptar ao novo local $-1^{a}$ parte

\begin{tabular}{|c|c|c|c|c|c|c|c|c|c|c|}
\hline \multirow{2}{*}{ Empresa } & \multicolumn{9}{|c|}{$\begin{array}{c}\text { Ciclo do } \\
\text { Produto }\end{array}$} & \multicolumn{10}{|c|}{ Escola de Uppsala } \\
\cline { 2 - 14 } & CP 6 & CP 8 & EU 1 & EU 2 & EU 3 & EU 4 & EU 6 & EU 8 & EU 9 & EU 11 \\
\hline Arezzo & 0 & 0 & 0 & 2 & 1 & 0 & 0 & 3 & 0 & 0 \\
\hline Carmen Steffens & 0 & 0 & 0 & 4 & 1 & 0 & 0 & 0 & 0 & 0 \\
\hline Chilli Beans & 0 & 0 & 0 & 7 & 0 & 0 & 0 & 0 & 0 & 1 \\
\hline Lilica Ripilica & 0 & 1 & 1 & 11 & 0 & 0 & 0 & 1 & 1 & 0 \\
\hline Morana & 0 & 0 & 0 & 4 & 0 & 0 & 0 & 0 & 0 & 0 \\
\hline Mundo Verde & 0 & 0 & 0 & 4 & 0 & 0 & 0 & 0 & 0 & 2 \\
\hline Nobel & 0 & 0 & 0 & 0 & 0 & 0 & 0 & 0 & 0 & 0 \\
\hline O Boticário & 4 & 0 & 4 & 11 & 1 & 1 & 4 & 1 & 0 & 0 \\
\hline Spoleto & 0 & 0 & 0 & 8 & 0 & 0 & 2 & 3 & 0 & 0 \\
\hline Victor Hugo & 0 & 0 & 0 & 8 & 0 & 0 & 6 & 1 & 0 & 1 \\
\hline Total por proposição & 4 & 1 & 5 & 59 & 3 & 1 & 12 & 9 & 1 & 4 \\
\hline Total por Teoria & 5 & & & & & 94 & & & \\
\hline
\end{tabular}


Tabela 14 - Freqüência das proposições por entrevista: como se adaptar ao novo local $-2^{\mathrm{a}}$ parte

\begin{tabular}{|c|c|c|c|c|c|c|c|c|}
\hline \multirow{2}{*}{ Empresa } & Internalização & $\begin{array}{c}\text { Paradigma } \\
\text { Eclético }\end{array}$ & \multicolumn{5}{|c|}{ Competitividade Global } \\
\cline { 2 - 10 } & IN 3 & PE 1 & CC 1 & CC 2 & CC 3 & CC 4 & CC 5 & CC 6 \\
\hline Arezzo & 0 & 0 & 0 & 0 & 0 & 0 & 2 & 2 \\
\hline Carmen Steffens & 0 & 0 & 0 & 1 & 1 & 1 & 0 & 0 \\
\hline Chilli Beans & 0 & 0 & 0 & 0 & 0 & 0 & 0 & 3 \\
\hline Lilica Ripilica & 0 & 0 & 1 & 1 & 0 & 1 & 3 & 4 \\
\hline Morana & 0 & 0 & 0 & 0 & 0 & 0 & 0 & 0 \\
\hline Mundo Verde & 0 & 0 & 0 & 2 & 0 & 0 & 5 & 2 \\
\hline Nobel & 0 & 0 & 0 & 0 & 0 & 0 & 0 & 0 \\
\hline O Boticário & 0 & 0 & 0 & 1 & 0 & 0 & 1 & 8 \\
\hline Spoleto & 1 & 0 & 0 & 0 & 0 & 1 & 4 & 3 \\
\hline Victor Hugo & 0 & 1 & 0 & 0 & 0 & 0 & 0 & 1 \\
\hline Total por proposição & 1 & 1 & 1 & 5 & 1 & 3 & 15 & 23 \\
\hline Total por Teoria & 1 & 1 & & & 48 & & \\
\hline
\end{tabular}

Tabela 15 - Freqüiência das proposições por entrevista: como se adaptar ao novo local $-3^{\text {a }}$ parte

\begin{tabular}{|c|c|c|c|c|c|c|c|c|c|c|c|c|}
\hline \multirow[t]{2}{*}{ Empresa } & \multicolumn{4}{|c|}{$\begin{array}{l}\text { Gestão Estratégica } \\
\text { de Operações }\end{array}$} & \multicolumn{4}{|c|}{$\begin{array}{c}\text { Gestão de } \\
\text { Competências }\end{array}$} & \multicolumn{2}{|c|}{$\begin{array}{c}\text { Gestão do } \\
\text { Conhecimento }\end{array}$} & \multicolumn{2}{|c|}{$\begin{array}{l}\text { Abordagem } \\
\text { Intercultural }\end{array}$} \\
\hline & EO 1 & EO 2 & EO 3 & EO 4 & GC 1 & GC 2 & GC 3 & GC 4 & $\mathrm{CO} 1$ & $\mathrm{CO} 2$ & AI 1 & AI 5 \\
\hline Arezzo & 0 & 0 & 0 & 0 & 0 & 0 & 6 & 0 & 3 & 2 & 0 & 0 \\
\hline Carmen Steffens & 2 & 2 & 0 & 0 & 1 & 0 & 3 & 1 & 1 & 1 & 0 & 0 \\
\hline Chilli Beans & 0 & 5 & 0 & 0 & 0 & 1 & 3 & 0 & 5 & 2 & 1 & 2 \\
\hline Lilica Ripilica & 3 & 4 & 1 & 0 & 1 & 0 & 5 & 0 & 5 & 3 & 0 & 1 \\
\hline Morana & 2 & 3 & 0 & 0 & 3 & 1 & 1 & 0 & 4 & 3 & 0 & 0 \\
\hline Mundo Verde & 2 & 3 & 0 & 0 & 0 & 0 & 5 & 0 & 4 & 0 & 0 & 1 \\
\hline Nobel & 0 & 1 & 0 & 2 & 0 & 0 & 2 & 0 & 2 & 1 & 0 & 0 \\
\hline O Boticário & 1 & 1 & 0 & 0 & 0 & 0 & 3 & 0 & 6 & 3 & 0 & 2 \\
\hline Spoleto & 1 & 1 & 0 & 4 & 0 & 0 & 1 & 0 & 1 & 0 & 0 & 0 \\
\hline Victor Hugo & 4 & 4 & 0 & 0 & 0 & 0 & 0 & 0 & 2 & 1 & 1 & 0 \\
\hline Total por proposição & 15 & 24 & 1 & 6 & 5 & 2 & 29 & 1 & 33 & 16 & 2 & 6 \\
\hline Total por Teoria & \multicolumn{4}{|c|}{46} & \multicolumn{4}{|c|}{37} & \multicolumn{2}{|c|}{49} & \multicolumn{2}{|c|}{8} \\
\hline
\end{tabular}

A Escola de Uppsala obteve a maior participação nesta etapa da análise dos dados. Foram identificados trechos pertinentes a oito de suas 12 proposições. A proposição EU 1 - a firma internacionaliza por meio de um processo gradual - participou do O Boticário (4) e Lilica Ripilica (1). A proposição EU 2 - a firma adquire gradativamente conhecimento do local para o qual pretende se deslocar (aprendizagem) - foi aquela que apresentou a maior quantidade de registros relacionados a maneira como as empresas se adaptaram aos países estrangeiros. 
Apenas na entrevista da Nobel não foi identificado trecho. A demais empresas apresentaram registros: Lilica Ripilica (11), O Boticário (11), Victor Hugo (8), Spoleto (8), Chilli Beans (7), Morana (4), Mundo Verde (4), Carmen Steffens (4) e Arezzo (2). A proposição EU 3 - a cultura em determinado local interfere no processo de expansão da empresa - foi identificada na Arezzo (1), O Boticário (1) e Carmen Steffens (1). A proposição EU 4 - o idioma em determinado local interfere no processo de expansão da empresa - foi percebida apenas no $\mathrm{O}$ Boticário uma única vez. A proposição EU 6 - as praticas de negócio em determinado local interferem no processo de expansão da empresa - foi reconhecida na Victor Hugo (6), O Boticário (4) e Spoleto (2). A proposição EU 8 - o relacionamento com os clientes em determinado local interfere no processo de expansão da empresa - apresentou registros nas entrevistas Arezzo (3), Spoleto (3), Victor Hugo (1), Lilica Ripilica (1) e O Boticário (1). A proposição EU 9 - o relacionamento com os fornecedores em determinado local interfere no processo de expansão da empresa - apenas participou com um trecho na entrevista da Lilica Ripilica. A proposição EU 11 - o relacionamento com as agências reguladoras em determinado local interfere no processo de expansão da empresa - foi verificada no Mundo Verde (2), Victor Hugo (1) e Chilli Beans (1).

As duas proposições da Abordagem sobre Gestão do Conhecimento foram identificadas nos discursos dos gestores. O segundo maior número de registros refere-se a proposição CO 1 - o conhecimento resulta do compartilhamento de experiências entre os membros da organização - e todas a empresas apresentaram trechos: O Boticário (6), Chilli Beans (5), Lilica Ripilica (5), Morana (4), Mundo Verde (4), Arezzo (3), Victor Hugo (2), Nobel (2), Spoleto (1) e Carmen Steffens (1). A proposição CO 2 - o conhecimento resulta do compartilhamento da aprendizagem entre os membros da organização - foi identificada nas empresas Morana (3), Lilica Ripilica (3), O Boticário (3), Chilli Beans (2), Arezzo (2), Victor Hugo (1), Nobel (1) e Carmen Steffens (1).

A Teoria sobre Competição e Competitividade Global participou com suas seis proposições. A proposição CC 1 - a empresa determina a sua estratégia em função da excelência operacional - apresentou um trecho na entrevista da Lilica Ripilica. A proposição CC 2 - a empresa determina sua estratégia pela análise de produtos - foi identificada no Mundo Verde (2), Lilica Ripilica (1), O Boticário (1) e Carmen Steffens (1). A proposição CC 3 - a empresa define sua estratégia pela análise de concorrentes - também contribuiu com um trecho da entrevista da Carmen Steffens. A proposição CC 4 - a empresa define sua estratégia pela 
análise de consumidores - foi percebida nas entrevistas da Lilica Ripilica (1), Spoleto (1) e Carmen Stffens (1). A proposição CC 5 - a empresa determina sua estratégia pela análise de oportunidades - foi identificada nos discurso do gestor do Mundo Verde (5), Spoleto (4), Lilica Ripilica (3), Arezzo (2) e O Boticário (1). E a proposição CC 6 - a empresa define seu posicionamento estratégico para atuar em novo local - participou das entrevistas do $\mathrm{O}$ Boticário (8), Lilica Ripilica (4), Chilli Beans (3), Spoleto (3), Arezzo (2), Mundo Verde (2) e Victor Hugo (1).

A Abordagem sobre Gestão Estratégica de Operações contribuiu com quatro proposições de um total de seis proposições. A proposição EO 1 - a firma escolhe a estrutura organizacional para atuar no mercado em função das características deste mercado - participou da Victor Hugo (4), Lilica Ripilica (3), Morana (2), Mundo Verde (2), Carmen Steffens (2), O Boticário (1) e Spoleto (1). A proposição EO 2 - a firma escolhe a estrutura organizacional para atuar no mercado em função de suas características internas - foi percebida na entrevista da Chilli Beans (5), Victor Hugo (4), Lilica Ripilica (4), Morana (3), Mundo Verde (3), Carmen Steffens (2), O Boticário (1), Nobel (1) e Spoleto (1). A proposição EO 3 - a firma escolhe a estrutura organizacional para atuar no mercado em função da sua habilidade de gerenciar além fronteiras - foi identificada na entrevista da Lilica Ripilica e um único trecho. A proposição EO 4 - a firma escolhe a estrutura organizacional para atuar no mercado em função de sua rede de relacionamentos internacionais - foi percebida no Spoleto (4) e Nobel (2).

A Abordagem sobre Gestão de Competências apresentou quatro de suas sete proposições. A proposição GC 1 - a empresa tem a capacidade de aprender com o ambiente - foi identificada no discurso do gestor da Morana (3), Lilica Ripilica (1) e Carmen Steffens (1). A proposição GC 2 - a empresa tem a capacidade de desenvolver estratégias - foi percebida na Morana (1) e Chilli Beans (1). A proposição GC 3 - a empresa tem a capacidade de disponibilizar as funções de operações - foi a terceira proposição a apresentar a maior quantidade de registros. As empresas que apresentaram registros foram Arezzo (6), Mundo Verde (5), Lilica Ripilica (5), Chilli Beans (3), O Boticário (3), Carmen Steffens (3), Nobel (2), Morana (1) e Spoleto (1). A proposição GC 4 - a empresa tem a capacidade de disponibilizar a função de desenvolvimento de produto - foi identificado um trecho na entrevista da Carmen Steffens.

Foram identificadas duas proposições da Abordagem Intercultural de um total de cinco. A proposição AI 1 - a cultura de um país ou região interfere na cultura da organização - foi 
identificada nas empresas Victor Hugo (1) e Chilli Beans (1). A proposição AI5 - os padrões de comportamento de um grupo influenciam a gestão da empresa - participou das entrevistas da Chilli Beans (2), O Boticário (2), Mundo Verde (1) e Lilica Ripilica (1).

A Teoria do Ciclo do Produto apresentou duas proposições de um total de quatorze. A proposição CP 6 - a fase de crescimento do produto espalha a produção pelos países desenvolvidos - foi identifica apenas na entrevista do O Boticário com quatro trechos. A proposição CP 8 - a fase de crescimento do produto inicia a difusão da tecnologia apresentou apenas um trecho para Lilica Ripilica.

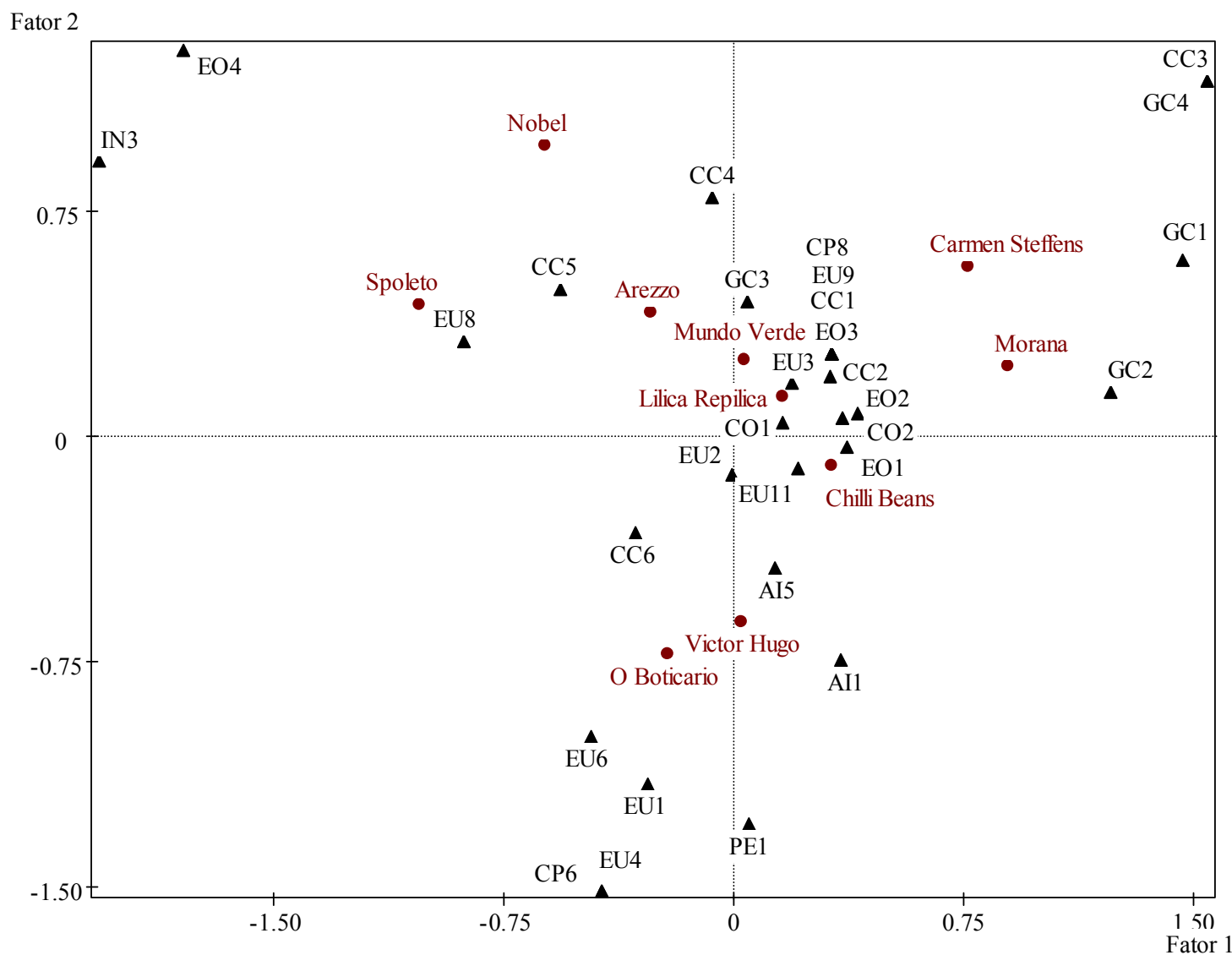

Gráfico 6 - Análise de Correspondência por proposição e por empresa: como se adaptar ao novo local

A Teoria de Internalização foi identificada em apenas um trecho do discurso do gestor do Spoleto e classificada como proposição IN 3 - a firma integra a produção quando a especificidade dos ativos é grande. Do mesmo modo, percebeu-se um trecho na entrevista da 
Victor Hugo relacionado ao Paradigma Eclético, proposição PE 1 - a firma possui vantagem específica de propriedade de marcas.

A Análise de Correspondência relativa à maneira como as empresas adaptam a operação nos países estrangeiros onde entraram - como se adaptar ao novo local - encontra-se no Gráfíco 6. A inércia associada ao Gráfico 6 é de 38,28\%. Todos os grupos tiveram contribuição na construção dos dois eixos.

\subsection{O processo de internacionalização das empresas de varejo brasileiras: teorias}

Esta seção mostra as análises dos dados de modo agregado: cada empresa em relação às teorias sobre internacionalização. Os resultados são assim disponibilizados para garantir o objetivo principal da tese: investigar a relação entre as teorias sobre internacionalização de empresas e o discurso dos gestores das dez empresas de varejo brasileiras em seu processo de expansão internacional (Gráfico 7).

O Gráfico 7 traz a Análise de Correspondência, considerando o texto completo. Esse mapa perceptual foi construído a partir dos dados oriundos da Análise de Conteúdo, contidos nas Tabelas de 1 a 4 . A inércia associada ao Gráfico 7 é de 57,06\%. Nenhuma das proposições deixa de contribuir para a construção dos dois eixos, o que é importante para considerar a análise representativa.

Ao analisar de forma agregada os dados do discurso do gestor da Arezzo, identificam-se as estruturas teóricas mais presentes. A primeira é a Teoria sobre Competição e Competitividade Global, com 55 ocorrências. A ela seguem-se a Escola de Uppsala, com 15; Abordagem sobre Gestão de Competências, com dez; Abordagem sobre Gestão do Conhecimento, com sete; Abordagem sobre Gestão Estratégica de Operações e Paradigma Eclético, ambos com duas ocorrências, e Teoria do Poder de Mercado, com uma. Não foram identificadas ocorrências relativas à Teoria do Ciclo do Produto, Teoria de Internalização, Escola Nórdica e Abordagem Intercultural. 
Fator 2

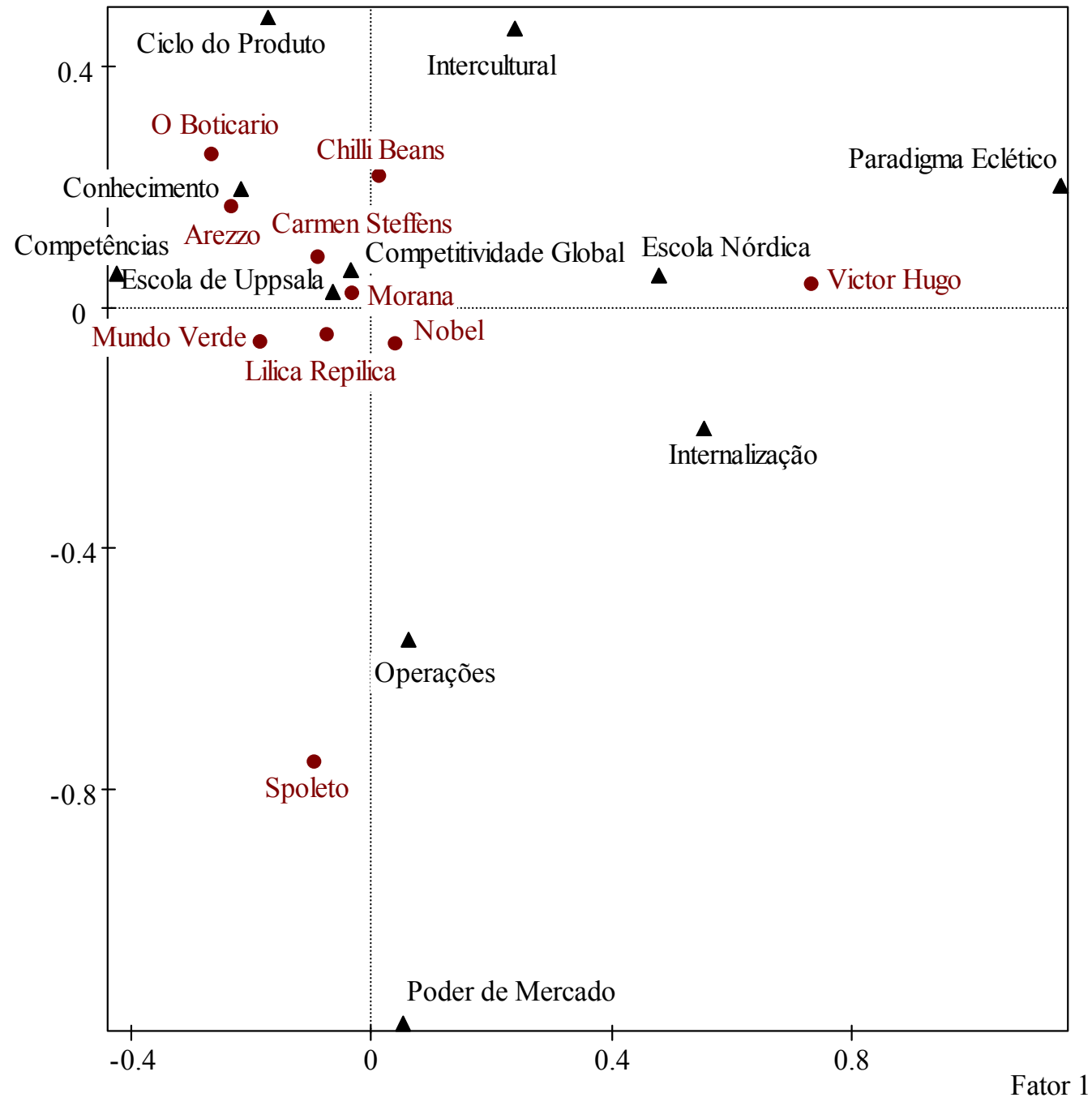

Gráfico 7 - Análise de Correspondência entre empresas e teorias: dados agregados

A Carmen Steffens apresenta também com maior incidência trechos classificados como representativos da Teoria sobre Competição e Competitividade Global, totalizando 50 registros. Em seqüência, identicamente à Arezzo, aparece a Escola de Uppsala, com 18 registros; Abordagem sobre Gestão de Competências, com oito; Abordagem sobre Gestão do Conhecimento, com sete; Abordagem sobre Gestão Estratégica de Operações, com cinco; Paradigma Eclético, com três. No caso da Arezzo, incide a Escola Nórdica, com dois registros, além de Poder de Mercado e Teoria de Internalização, com apenas uma ocorrência cada. Não foram identificados trechos relacionados à Teoria do Ciclo do Produto e Abordagem Intercultural. 
A entrevista da Chilli Beans tem como principal participação as mesmas duas estruturas teóricas vistas nas entrevistas anteriores: Teoria sobre Competição e Competitividade Global (47 ocorrências) e Escola de Uppsala (19 ocorrências). Verificam-se em seguida a Abordagem sobre Gestão do Conhecimento, com nove registros; Paradigma Eclético e Abordagem sobre Gestão Estratégica de Operações, com cinco registros cada uma; Abordagem sobre Gestão de Competências, com quatro registros, e Abordagem Intercultural, com três. Do total de 11 estruturas teóricas não se verificou incidência da Teoria do Poder de Mercado, Teoria do Ciclo do Produto, Teoria de Internalização e Escola Nórdica.

No discurso do gestor da Lilica Ripilica se repetem as duas estruturas teóricas com maior incidência nas empresas já citadas: Teoria sobre Competição e Competitividade Global (52 registros) e Escola de Uppsala (35). As demais estruturas teóricas são Abordagem sobre Gestão Estratégica de Operações, com 16 registros; Abordagem sobre Gestão do Conhecimento, com oito; Abordagem sobre Gestão de Competências, com sete; Paradigma Eclético, com três; Teoria de Internalização, com dois; Teoria do Ciclo do Produto, Escola Nórdica e Abordagem Intercultural, com um registro cada. Nessa entrevista só não incide a Teoria do Poder de Mercado.

A Morana mostrou trechos relacionados a todas as estruturas teóricas e de acordo com os resultados da análise dos dados das entrevistas apresentadas até este ponto. Primeiramente, aparece com maior número de ocorrências a Teoria sobre Competição e Competitividade Global (38), seguida da Escola de Uppsala (31). Depois aparecem Abordagem sobre Gestão do Conhecimento, com 13 registros; Abordagem sobre Gestão Estratégica de Operações, com sete; Abordagem sobre Gestão de Competências, com cinco; Teoria de Internalização, com quatro; Paradigma Eclético, com três. A Teoria do Poder de Mercado e a Escola Nórdica figuram com dois trechos cada uma, e a Abordagem Intercultural e a Teoria do Ciclo do Produto, com um.

A entrevista do gestor do Mundo Verde apontou para a participação de sete das 11 estruturas teóricas. Não foram identificados trechos que remetessem à Teoria do Poder de Mercado, Teoria do Ciclo do Produto, Teoria de Internalização e Escola Nórdica. Mais uma vez, a maior participação é da Teoria sobre Competição e Competitividade Global, com 33 registros. Com dez ocorrências em cada estrutura verificam-se a Escola de Uppsala, a Abordagem sobre Gestão Estratégica de Operações e a Abordagem sobre Gestão de Competências. Em 
seqüência, identifica-se a Abordagem sobre Gestão do Conhecimento, com quatro ocorrências, o Paradigma Eclético, com duas, e a Abordagem Intercultural, com um registro apenas.

A Teoria sobre Competição e Competitividade Global e a Escola de Uppsala figuram com as maiores incidências também no discurso do gestor da Nobel, com 27 e 14 registros, respectivamente. Em seguida, identificam-se a Abordagem sobre Gestão Estratégica de Operações, com cinco ocorrências; a Abordagem sobre Gestão do Conhecimento, com quatro; a Abordagem sobre Gestão de Competências e o Paradigma Eclético, com três ocorrências cada; a Teoria do Poder de Mercado e a Escola Nórdica, com dois registros cada. Por fim, identifica-se um único registro para a Teoria do Ciclo do Produto. Não foram identificados trechos relacionados à Teoria da Internalização e à Abordagem Intercultural.

Apenas duas entrevistas não apresentaram trechos relacionados ao Paradigma Eclético. Uma delas foi a do $\mathrm{O}$ Boticário, em que também não foram percebidos trechos referentes à Teoria de Internalização e à Escola Nórdica. Contudo, as duas principais estruturas teóricas presentes em trechos dessa entrevista continuam sendo a Teoria sobre Competição e Competitividade Global, com 31 registros, e a Escola de Uppsala, com 30. Depois foi identificada a Abordagem sobre Gestão do Conhecimento, com nove ocorrências, seguida da Teoria do Ciclo do Produto, com quatro, Abordagem sobre Gestão de Competências, com três, Abordagem Intercultural e Abordagem sobre Gestão Estratégica de Operações, com dois registros cada uma, e, por fim, a Teoria do Poder de Mercado, com um registro.

A segunda entrevista que não apresenta a participação da estrutura teórica Paradigma Eclético é a do Spoleto. Também não foram verificados trechos relacionados à Teoria do Ciclo do Produto, Escola Nórdica e Abordagem Intercultural. No discurso do gestor dessa empresa, a predominância da Teoria sobre Competição e Competitividade Global e da Escola de Uppsala permanecem. A primeira apresenta 29 registros e a segunda, 17. Em seqüência, identificam-se a Abordagem sobre Gestão Estratégica de Operações, com 16 registros; Teoria do Poder de Mercado, com sete; Abordagem sobre Gestão de Competências e Abordagem sobre Gestão do Conhecimento, com três cada uma; e Teoria de Internalização, com um registro.

A entrevista do gestor da Victor Hugo só não mostrou trechos relacionados à Abordagem sobre Gestão de Competências. Todas as demais estruturas teóricas participaram, observando 
a seguinte ordem: com a maior quantidade de registros, 46, figura a Teoria sobre Competição e Competitividade Global, seguida pela Escola de Uppsala, com 21 ocorrências. Depois aparecem o Paradigma Eclético, com 20 registros; a Abordagem sobre Gestão Estratégica de Operações, com dez; Abordagem sobre Gestão do Conhecimento e Teoria de Internalização, com três cada uma; Teoria do Poder de Mercado, Escola Nórdica e Abordagem Intercultural, com duas ocorrências cada, e, por último, a Teoria do Ciclo do Produto, com um registro apenas.

\subsubsection{Análise dos dados por teoria e por empresa: por que sair}

A análise dos dados das Tabelas 5 e 6 mostrou as teorias que estão mais relacionadas a cada empresa, no que se refere aos motivos que as levaram a se internacionalizar. A Teoria sobre Competição e Competitividade Global se destacou com a maior incidência de trechos para todas as empresas estudadas.

Quadro 4 - Teorias relacionadas a por que sair para cada empresa

\begin{tabular}{|c|c|c|c|c|}
\hline Empresas & $\begin{array}{l}1^{\mathrm{a}} \text { estrutura } \\
\text { teórica }\end{array}$ & $\begin{array}{l}2^{\mathrm{a}} \text { estrutura } \\
\text { teórica }\end{array}$ & $\begin{array}{l}3^{\mathrm{a}} \text { estrutura } \\
\text { teórica }\end{array}$ & $\begin{array}{l}4^{\mathrm{a}} \text { estrutura } \\
\text { teórica }\end{array}$ \\
\hline Arezzo & $\begin{array}{c}\text { Competição e } \\
\text { Competitividade Global }\end{array}$ & Paradigma Eclético & Nenhuma & Nenhuma \\
\hline $\begin{array}{l}\text { Carmen } \\
\text { Steffens }\end{array}$ & $\begin{array}{c}\text { Competição e } \\
\text { Competitividade Global }\end{array}$ & $\begin{array}{l}\text { Poder de Mercado } \\
\text { Paradigma Eclético } \\
\text { Escola de Uppsala } \\
\text { Escola Nórdica }\end{array}$ & Nenhuma & Nenhuma \\
\hline Chilli Beans & $\begin{array}{c}\text { Competição e } \\
\text { Competitividade Global }\end{array}$ & $\begin{array}{c}\text { Gestão do } \\
\text { Conhecimento }\end{array}$ & Nenhuma & Nenhuma \\
\hline Lilica Ripilica & $\begin{array}{c}\text { Competição e } \\
\text { Competitividade Global }\end{array}$ & Paradigma Eclético & Nenhuma & Nenhuma \\
\hline Morana & $\begin{array}{c}\text { Competição e } \\
\text { Competitividade Global }\end{array}$ & $\begin{array}{c}\text { Gestão do } \\
\text { Conhecimento }\end{array}$ & Poder de Mercado & $\begin{array}{l}\text { Ciclo do Produto } \\
\text { Escola de } \\
\text { Uppsala } \\
\text { Intercultural }\end{array}$ \\
\hline Mundo Verde & $\begin{array}{c}\text { Competição e } \\
\text { Competitividade Global }\end{array}$ & Nenhuma & Nenhuma & Nenhuma \\
\hline Nobel & $\begin{array}{c}\text { Competição e } \\
\text { Competitividade Global }\end{array}$ & $\begin{array}{l}\text { Poder de Mercado } \\
\text { Ciclo do Produto } \\
\text { Paradigma Eclético } \\
\text { Escola Nórdica }\end{array}$ & Nenhuma & Nenhuma \\
\hline O Boticário & $\begin{array}{c}\text { Competição e } \\
\text { Competitividade Global }\end{array}$ & $\begin{array}{l}\text { Escola de Uppsala } \\
\text { Poder de Mercado }\end{array}$ & Nenhuma & Nenhuma \\
\hline Spoleto & $\begin{array}{c}\text { Competição e } \\
\text { Competitividade Global }\end{array}$ & Nenhuma & Nenhuma & Nenhuma \\
\hline Victor Hugo & $\begin{array}{c}\text { Competição e } \\
\text { Competitividade Global }\end{array}$ & Paradigma Eclético & Poder de Mercado & Escola Nórdica \\
\hline
\end{tabular}

Cada empresa demonstrou ter uma ordem de proximidade com as teorias, de acordo com o Quadro 4. O Gráfico 8 apresenta o resultado da Análise de Correspondência, e a inércia 
associada a ele é de $71,56 \%$. Todas as proposições tiveram contribuição na construção desses dois eixos.

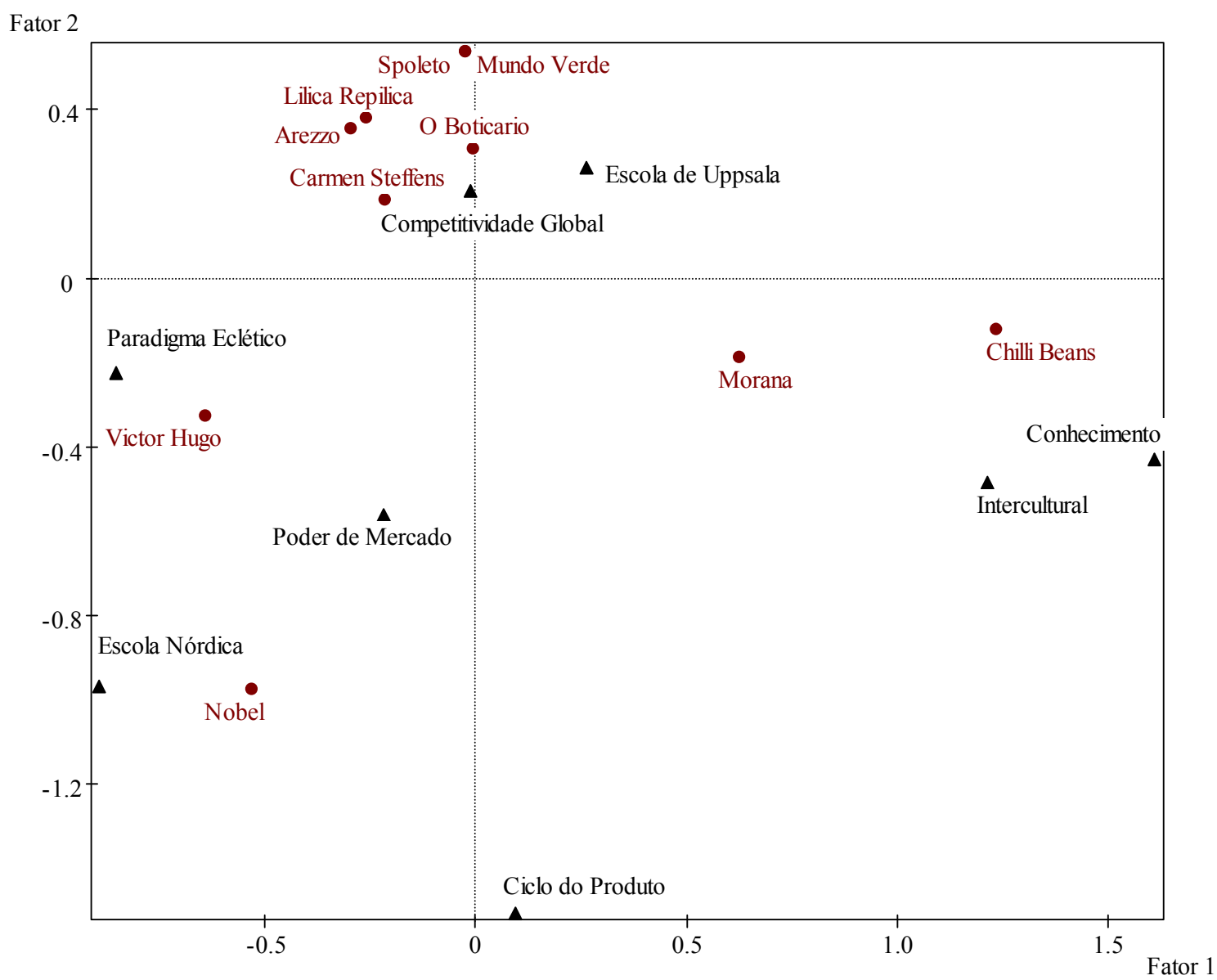

Gráfico 8 - Análise de Correspondência: por que sair

\subsubsection{Análise dos dados por teoria e por empresa: para onde ir}

Todas as empresas apresentaram a Teoria sobre Competição e Competitividade Global como a mais associada à escolha do país estrangeiro e às razões que levaram a essa decisão, como se pode ver nas Tabelas 7 e 8 e no Quadro 5. O Gráfico 9 demonstra, por intermédio de um mapa perceptual, o resultado da Análise de Correspondência desta seção. A inércia associada ao Gráfico 9 é de 87,39\%. Mais uma vez, todas as proposições teóricas tiveram contribuição na construção desses dois eixos. 
Quadro 5 - Teorias relacionadas a para onde ir para cada empresa

\begin{tabular}{|c|c|c|c|c|}
\hline Empresa & $\begin{array}{l}1^{\mathrm{a}} \text { estrutura } \\
\text { teórica }\end{array}$ & $\begin{array}{l}2^{\mathrm{a}} \text { estrutura } \\
\text { teórica }\end{array}$ & $\begin{array}{l}3^{\mathrm{a}} \text { estrutura } \\
\text { teórica }\end{array}$ & $\begin{array}{l}4^{\mathrm{a}} \text { estrutura } \\
\text { teórica }\end{array}$ \\
\hline Arezzo & $\begin{array}{c}\text { Competição e } \\
\text { Competitividade Global }\end{array}$ & $\begin{array}{l}\text { Escola de } \\
\text { Uppsala }\end{array}$ & Poder de Mercado & Nenhuma \\
\hline $\begin{array}{l}\text { Carmen } \\
\text { Steffens }\end{array}$ & $\begin{array}{c}\text { Competição e } \\
\text { Competitividade Global }\end{array}$ & $\begin{array}{l}\text { Escola de } \\
\text { Uppsala }\end{array}$ & Paradigma Eclético & Nenhuma \\
\hline Chilli Beans & $\begin{array}{c}\text { Competição e } \\
\text { Competitividade Global }\end{array}$ & $\begin{array}{l}\text { Paradigma } \\
\text { Eclético }\end{array}$ & Escola de Uppsala & Nenhuma \\
\hline $\begin{array}{c}\text { Lilica } \\
\text { Ripilica } \\
\end{array}$ & $\begin{array}{c}\text { Competição e } \\
\text { Competitividade Global }\end{array}$ & $\begin{array}{l}\text { Escola de } \\
\text { Uppsala }\end{array}$ & Paradigma Eclético & Nenhuma \\
\hline Morana & $\begin{array}{c}\text { Competição e } \\
\text { Competitividade Global }\end{array}$ & $\begin{array}{l}\text { Escola de } \\
\text { Uppsala }\end{array}$ & Paradigma Eclético & Escola Nórdica \\
\hline Mundo Verde & $\begin{array}{c}\text { Competição e } \\
\text { Competitividade Global }\end{array}$ & $\begin{array}{l}\text { Escola de } \\
\text { Uppsala }\end{array}$ & Paradigma Eclético & Nenhuma \\
\hline Nobel & $\begin{array}{c}\text { Competição e } \\
\text { Competitividade Global }\end{array}$ & $\begin{array}{l}\text { Escola de } \\
\text { Uppsala }\end{array}$ & $\begin{array}{c}\text { Gestão Estratégica de } \\
\text { Operações }\end{array}$ & Nenhuma \\
\hline O Boticário & $\begin{array}{c}\text { Competição e } \\
\text { Competitividade Global }\end{array}$ & $\begin{array}{l}\text { Escola de } \\
\text { Uppsala }\end{array}$ & Nenhuma & Nenhuma \\
\hline Spoleto & $\begin{array}{c}\text { Competição e } \\
\text { Competitividade Global } \\
\text { Escola de Uppsala } \\
\text { Gestão Estratégica de } \\
\text { Operações } \\
\end{array}$ & Nenhuma & Nenhuma & Nenhuma \\
\hline Victor Hugo & $\begin{array}{c}\text { Competição e } \\
\text { Competitividade Global }\end{array}$ & $\begin{array}{l}\text { Paradigma } \\
\text { Eclético }\end{array}$ & Escola de Uppsala & $\begin{array}{c}\text { Ciclo do } \\
\text { Produto } \\
\text { Escola Nórdica }\end{array}$ \\
\hline
\end{tabular}

Fator 2

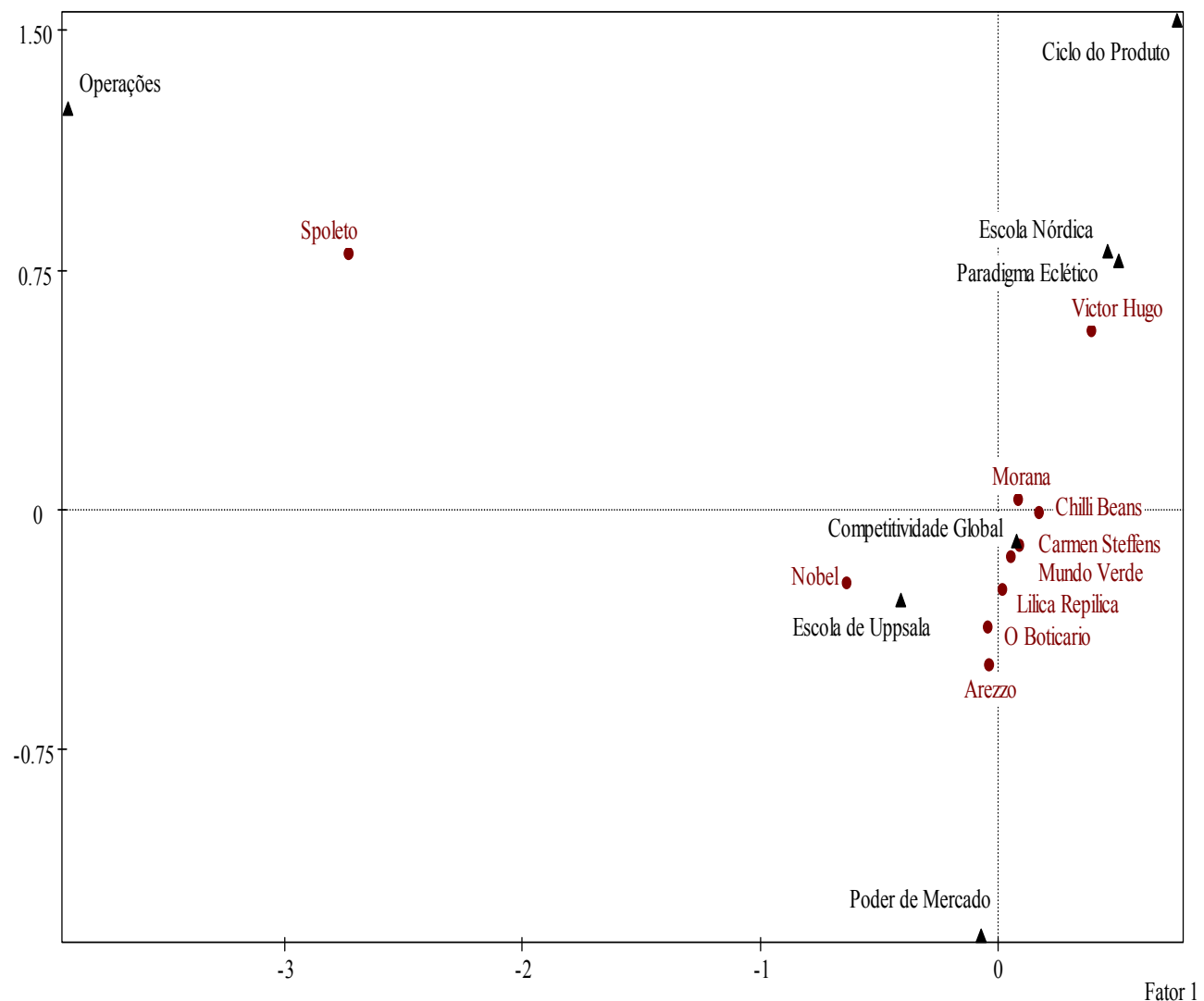

Gráfico 9 - Análise de Correspondência: para onde ir 


\subsubsection{Análise dos dados por teoria e por empresa: como entrar no novo local}

As Tabelas de 9 a 12 e os Quadros 6 e 7 mostram que a operação escolhida para iniciar atividade em países estrangeiros apenas não apresentou relação com a Teoria do Ciclo do Produto para as dez empresas pesquisadas. A Teoria sobre Competição e Competitividade Global foi identificada em sete das dez entrevistas. As exceções foram Morana e Lilica Ripilica, em que a Escola de Uppsala aparece de forma dominante, e a empresa Mundo Verde, em que a Abordagem sobre Gestão Estratégica de Operações e a Abordagem sobre Gestão de Competências se destacaram. O Gráfico 10 apresenta espacialmente a relação entre teorias e empresas para esta seção. A inércia associada ao Gráfico 10 é de 58,68\%. Todas as proposições tiveram contribuição na construção dos dois eixos representados no gráfico.

Quadro 6 - Teorias relacionadas a como entrar para cada empresa: $1^{\text {a }}$ parte

\begin{tabular}{|c|c|c|c|}
\hline Empresa & $1^{\mathrm{a}}$ estrutura teórica & $2^{\mathrm{a}}$ estrutura teórica & $3^{\mathrm{a}}$ estrutura teórica \\
\hline Arezzo & $\begin{array}{c}\text { Competição e } \\
\text { Competitividade Global }\end{array}$ & $\begin{array}{c}\text { Escola de Uppsala } \\
\text { Gestão de Competências }\end{array}$ & $\begin{array}{c}\text { Gestão do Conhecimento } \\
\text { Gestão Estratégica de } \\
\text { Operações }\end{array}$ \\
\hline Carmen Steffens & $\begin{array}{c}\text { Competição e } \\
\text { Competitividade Global }\end{array}$ & Escola de Uppsala & Gestão do Conhecimento \\
\hline Chilli Beans & $\begin{array}{c}\text { Competição e } \\
\text { Competitividade Global }\end{array}$ & Escola de Uppsala & Paradigma Eclético \\
\hline Lilica Ripilica & $\begin{array}{c}\text { Escola de Uppsala } \\
\text { Competição e } \\
\text { Competitividade Global }\end{array}$ & $\begin{array}{c}\text { Gestão Estratégica de } \\
\text { Operações }\end{array}$ & Internalização \\
\hline Morana & Escola de Uppsala & $\begin{array}{c}\text { Competição e } \\
\text { Competitividade Global }\end{array}$ & Internalização \\
\hline Mundo Verde & $\begin{array}{c}\text { Gestão Estratégica de } \\
\text { Operações } \\
\text { Gestão de Competências }\end{array}$ & $\begin{array}{c}\text { Competição e } \\
\text { Competitividade Global }\end{array}$ & Nenhuma \\
\hline Nobel & $\begin{array}{c}\text { Competição e } \\
\text { Competitividade Global }\end{array}$ & Escola de Uppsala & Paradigma Eclético \\
\hline O Boticário & $\begin{array}{c}\text { Competição e } \\
\text { Competitividade Global }\end{array}$ & Escola de Uppsala & Nenhuma \\
\hline Spoleto & $\begin{array}{c}\text { Competição e } \\
\text { Competitividade Global }\end{array}$ & $\begin{array}{c}\text { Gestão Estratégica de } \\
\text { Operações }\end{array}$ & Poder de Mercado \\
\hline Victor Hugo & $\begin{array}{c}\text { Competição e } \\
\text { Competitividade Global }\end{array}$ & $\begin{array}{l}\text { Escola de Uppsala } \\
\text { Internalização }\end{array}$ & $\begin{array}{c}\text { Paradigma Eclético } \\
\text { Gestão Estratégica de } \\
\text { Operações }\end{array}$ \\
\hline
\end{tabular}


Quadro 7 - Teorias relacionadas a como entrar para cada empresa: $2^{\mathrm{a}}$ parte

\begin{tabular}{|c|c|c|}
\hline Empresa & $4^{\mathrm{a}}$ estrutura teórica & $5^{\mathrm{a}}$ estrutura teórica \\
\hline Arezzo & Nenhuma & Nenhuma \\
\hline Carmen Steffens & Gestão de Competências & $\begin{array}{c}\text { Gestão Estratégica de Operações } \\
\text { Internalização } \\
\text { Escola Nórdica }\end{array}$ \\
\hline Chilli Beans & Nenhuma & Nenhuma \\
\hline Lilica Ripilica & $\begin{array}{c}\text { Escola Nórdica } \\
\text { Gestão de Competências } \\
\text { Paradigma Eclético } \\
\end{array}$ & Nenhuma \\
\hline Morana & $\begin{array}{l}\text { Gestão Estratégica de Operações } \\
\text { Gestão do Conhecimento }\end{array}$ & Escola Nórdica \\
\hline Mundo Verde & Nenhuma & Nenhuma \\
\hline Nobel & $\begin{array}{c}\text { Poder de Mercado } \\
\text { Escola Nórdica } \\
\text { Gestão Estratégica de Operações } \\
\text { Gestão de Competências } \\
\text { Gestão do Conhecimento }\end{array}$ & Nenhuma \\
\hline O Boticário & Nenhuma & Nenhuma \\
\hline Spoleto & $\begin{array}{c}\text { Escola de Uppsala } \\
\text { Gestão de Competências } \\
\text { Gestão do Conhecimento }\end{array}$ & Nenhuma \\
\hline Victor Hugo & Abordagem Intercultural & Nenhuma \\
\hline
\end{tabular}

Fator 2

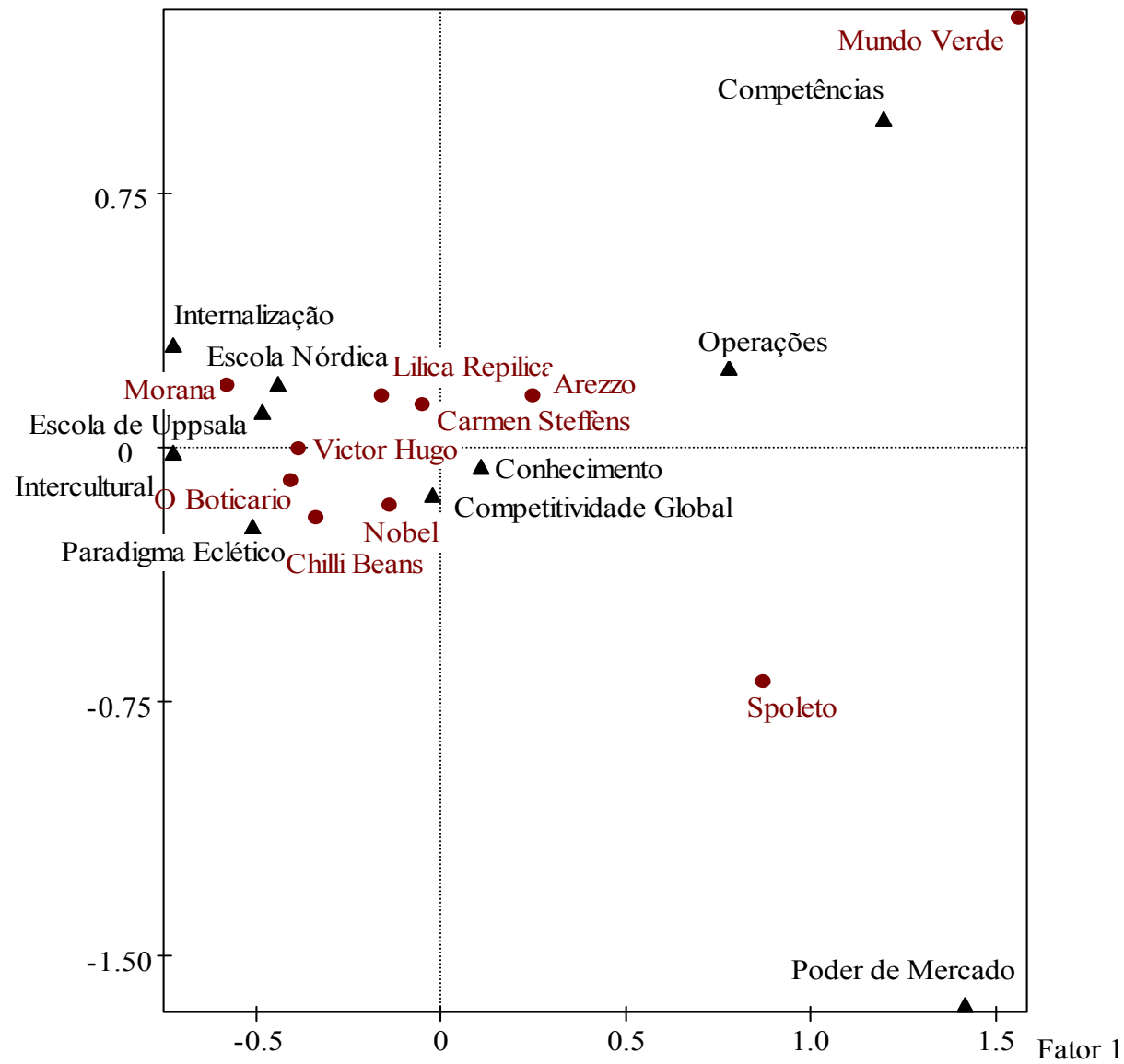

Gráfico 10 - Análise de Correspondência: como entrar no novo local 


\subsubsection{Análise dos dados por teoria e por empresa: como se adaptar ao novo local}

As Tabelas de 13 a 15 e os Quadros 8 e 9 demonstram que a forma com que sete empresas se adaptaram aos países estrangeiros está mais associada à Escola de Uppsala. As outras três empresas estão mais próximas a três estruturas teóricas distintas: Abordagem sobre Gestão do Conhecimento, Teoria sobre Competição e Competitividade Global e Abordagem sobre Gestão Estratégica de Operações.

O Gráfico 11 mostra essas relações. A inércia associada ao Gráfico 11 é de 62,39\%. Todas as proposições tiveram contribuição na construção dos dois eixos representados no gráfico, indicando ser suficiente a utilização de apenas duas dimensões na análise.

Quadro 8 - Teorias relacionadas a como se adaptar para cada empresa: $1^{\mathrm{a}}$ parte

\begin{tabular}{|c|c|c|c|}
\hline Empresas & $1^{\mathrm{a}}$ estrutura teórica & $2^{\mathrm{a}}$ estrutura teórica & $3^{\mathrm{a}}$ estrutura teórica \\
\hline Arezzo & $\begin{array}{c}\text { Escola de Uppsala Gestão } \\
\text { de Competências }\end{array}$ & Gestão do Conhecimento & $\begin{array}{c}\text { Competição e } \\
\text { Competitividade Global }\end{array}$ \\
\hline Carmen Steffens & $\begin{array}{c}\text { Escola de Uppsala Gestão } \\
\text { de Competências }\end{array}$ & $\begin{array}{c}\text { Gestão Estratégica de } \\
\text { Operações }\end{array}$ & $\begin{array}{c}\text { Competição e } \\
\text { Competitividade Global }\end{array}$ \\
\hline Chilli Beans & Escola de Uppsala & Gestão do Conhecimento & $\begin{array}{l}\text { Gestão Estratégica de } \\
\text { Operações }\end{array}$ \\
\hline Lilica Ripilica & Escola de Uppsala & $\begin{array}{c}\text { Competição e } \\
\text { Competitividade Global }\end{array}$ & $\begin{array}{c}\text { Gestão Estratégica de } \\
\text { Operações } \\
\text { Gestão do Conhecimento }\end{array}$ \\
\hline Morana & Gestão do Conhecimento & $\begin{array}{c}\text { Gestão Estratégica de } \\
\text { Operações } \\
\text { Gestão de Competências }\end{array}$ & Escola de Uppsala \\
\hline Mundo Verde & $\begin{array}{c}\text { Competição e } \\
\text { Competitividade Global }\end{array}$ & Escola de Uppsala & $\begin{array}{c}\text { Gestão Estratégica de } \\
\text { Operações } \\
\text { Gestão de Competências }\end{array}$ \\
\hline Nobel & $\begin{array}{c}\text { Gestão Estratégica de } \\
\text { Operações } \\
\text { Gestão do Conhecimento }\end{array}$ & Gestão de Competências & Nenhuma \\
\hline O Boticário & Escola de Uppsala & $\begin{array}{c}\text { Competição e } \\
\text { Competitividade Global }\end{array}$ & Gestão do Conhecimento \\
\hline Spoleto & Escola de Uppsala & $\begin{array}{c}\text { Competição e } \\
\text { Competitividade Global }\end{array}$ & $\begin{array}{c}\text { Gestão Estratégica de } \\
\text { Operações }\end{array}$ \\
\hline Victor Hugo & Escola de Uppsala & $\begin{array}{l}\text { Gestão Estratégica de } \\
\text { Operações }\end{array}$ & Gestão do Conhecimento \\
\hline
\end{tabular}


Quadro 9 - Teorias relacionadas a como se adaptar para cada empresa: $2^{\mathrm{a}}$ parte

\begin{tabular}{|c|c|c|c|}
\hline Empresas & $4^{\mathrm{a}}$ estrutura teórica & $5^{\mathrm{a}}$ estrutura teórica & $6^{\mathrm{a}}$ estrutura teórica \\
\hline Arezzo & Nenhuma & Nenhuma & Nenhuma \\
\hline Carmen Steffens & Gestão do Conhecimento & Nenhuma & Nenhuma \\
\hline Chilli Beans & Gestão de Competências & $\begin{array}{c}\text { Competição e } \\
\text { Competitividade Global } \\
\text { Intercultural }\end{array}$ & Nenhuma \\
\hline Lilica Ripilica & Gestão de Competências & $\begin{array}{c}\text { Ciclo do Produto } \\
\text { Abordagem Intercultural }\end{array}$ & Nenhuma \\
\hline Morana & Nenhuma & Nenhuma & Nenhuma \\
\hline Mundo Verde & Gestão do Conhecimento & Abordagem Intercultural & Nenhuma \\
\hline Nobel & Nenhuma & Nenhuma & Nenhuma \\
\hline O Boticário & Ciclo do Produto & Gestão de Competências & $\begin{array}{c}\text { Gestão Estratégica de } \\
\text { Operações } \\
\text { Intercultural }\end{array}$ \\
\hline Spoleto & $\begin{array}{c}\text { Internalização } \\
\text { Gestão de Competências } \\
\text { Gestão do Conhecimento }\end{array}$ & Nenhuma & Nenhuma \\
\hline Victor Hugo & $\begin{array}{c}\text { Paradigma Eclético } \\
\text { Competição e } \\
\text { Competitividade Global } \\
\text { Intercultural }\end{array}$ & Nenhuma & Nenhuma \\
\hline
\end{tabular}

Fator 2

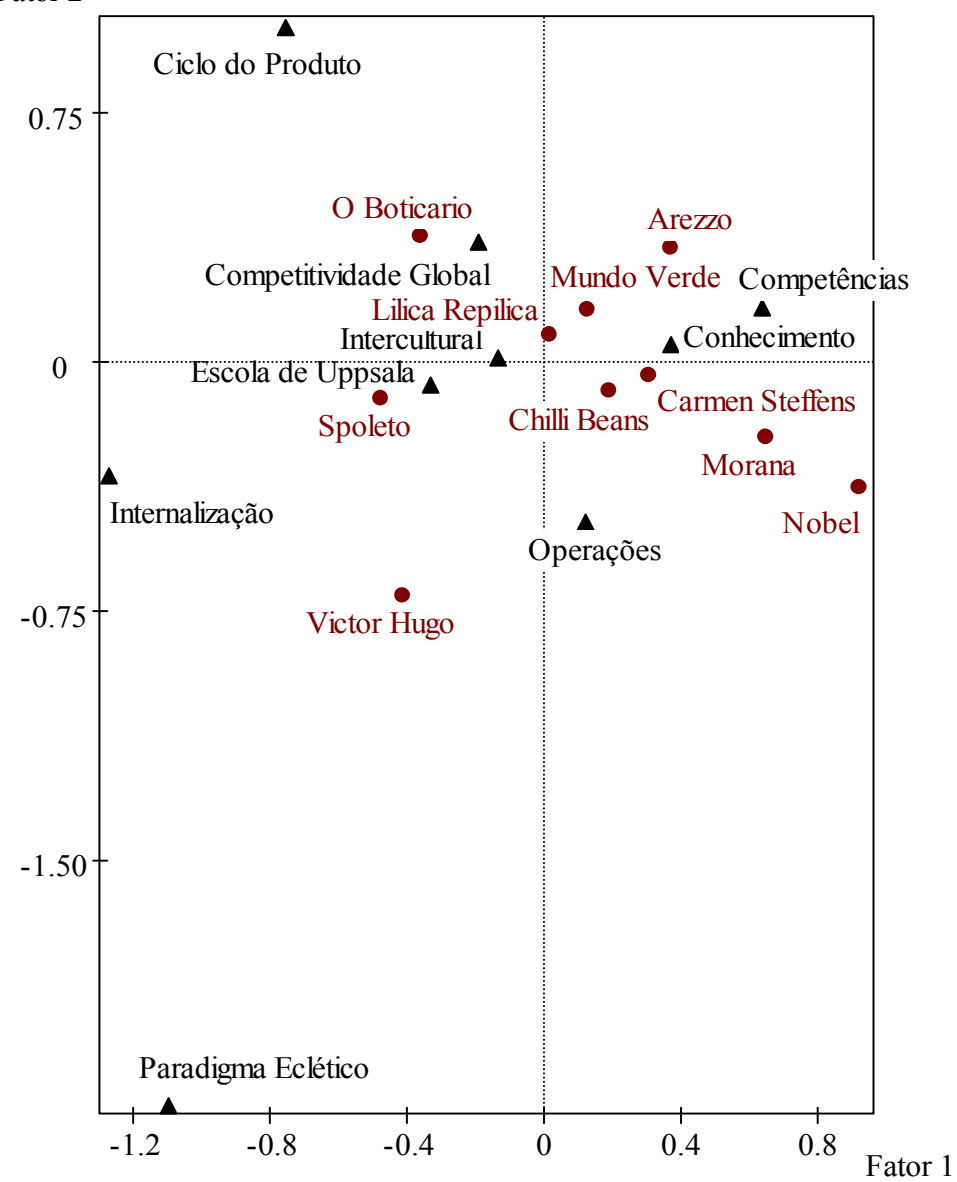

Gráfico 11 - Análise de Correspondência: como se adaptar ao novo local 
As inferências que a análise dos dados pôde descortinar com vistas a responder ao problema de pesquisa e atingir os objetivos traçados para esta tese serão apresentadas no capítulo 5 . Destacam-se também as limitações inerentes à estrutura teórica sobre internacionalização de empresas de varejo, aos procedimentos metodológicos e ao tamanho da amostra. A tese se encerra com sugestões para estudos futuros, investigações científicas que podem ser desenhadas a partir das informações organizadas neste documento. 


\section{CONCLUSÃO}

Essa seção tem a finalidade de recapitular o problema de pesquisa, o objetivo pricipal e os objetivos específicos desta tese, sumarizar suas pricipais contribuições, apontar as limitações inerentes à amplituide dos dados e à metodologia empregada, além de sugerir caminhos para pesquisas futuras relacionadas ao tema desenvolvidos neste trabalho.

O problema de pesquisa desta tese consistiu em verificar a relação entre as teorias sobre internacionalização de empresas e o processo de expansão de empresas de varejo brasileiras para países estrangeiros. O objetivo principal era identificar o que leva uma empresa a se deslocar para outros países, para onde se desloca (por que escolhe determinados locais em detrimento de outros), quais são os modos de entrada selecionados e como as empresas se adaptam aos novos locais, sob os conceitos de internacionalização de empresas. Para tanto, inicialmente foram pesquisados dados secundários provenientes de teses, dissertações, artigos relacionados ao tema, que foram registrados de forma ordenada e deram origem à proposição de uma Taxonomia de Encadeamento Teórico para a internacionalização das empresas em um sentido mais amplo (Ilustração 6). Ao se compararem as estruturas teóricas relativas à internacionalização de empresas de modo geral com as estruturas teóricas empregadas para a internacionalização de empresas de varejo, pôde-se perceber que apenas uma parte das teorias ou abordagens foi identificada nos estudos de varejo aqui assinalados - essa diferença é representada na Ilustração 19. Em seguida, realizou-se a pesquisa de campo por meio da coleta de entrevistas em profundidade com o gestor de cada uma das dez empresas de varejo pesquisadas - Arezzo, Carmen Steffens, Chilli Beans, Lilica Ripilica (Marisol), Morana, Mundo Verde, Nobel, O Boticário, Spoleto e Victor Hugo - e a Análise de Conteúdo e de Correspondência dos dados oriundos dessas entrevistas.

\subsection{Síntese - proposições e empresas}

As proposições (912 ocorrências) que tiveram maior participação para a totalidade do processo de internacionalização das empresas analisadas foram (Tabelas de 1 a 4, p. 121-125):

a) a empresa define seu posicionamento estratégico para atuar em novo local - CC 6 (221 trechos); 
b) a empresa determina sua estratégia pela análise de oportunidades - CC 5 (121 trechos);

c) a firma adquire gradativamente conhecimento do local para o qual pretende se deslocar (aprendizagem) - EU 2 (104 trechos);

d) o conhecimento resulta do compartilhamento de experiências entre os membros da organização - CO 1 (44 trechos);

e) a empresa tem a capacidade de disponibilizar as funções de operações - GC 3 (43 trechos);

f) a firma escolhe a estrutura organizacional para atuar no mercado em função de suas características internas - EO 2 (37 trechos);

g) a firma internacionaliza por meio de um processo gradual - EU 1 (34 trechos);

h) a firma escolhe a estrutura organizacional para atuar no mercado em função de sua rede de relacionamentos internacionais - EO 4 (24 trechos);

i) a empresa define sua estratégia pela análise de concorrentes - CC 3 (23 trechos);

j) a firma possui vantagem específica de propriedade de marcas - PE 1 (20 trechos);

1) o conhecimento resulta do compartilhamento da aprendizagem entre os membros da organização - CO 2 (17 trechos).

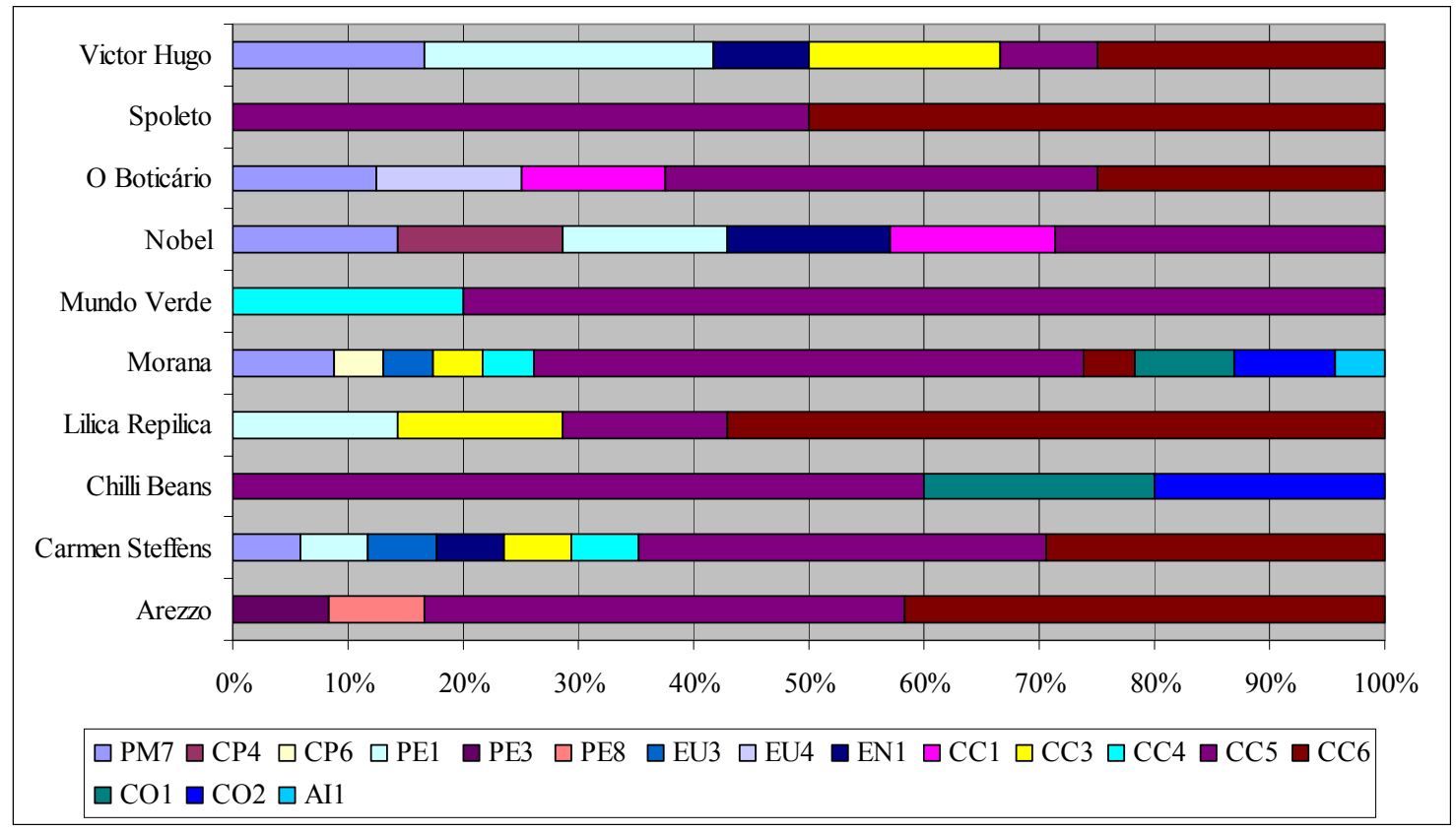

Gráfico 12 - Proposições e empresas: por que sair 
As proposições que apresentaram maior incidência nas razões que levaram a empresa a se internacionalizar (98 trechos relacionados a por que sair) foram (Tabelas 5 e 6, p. 129-130; Gráfico12):

a) a empresa determina sua estratégia pela análise de oportunidades - CC 5 (37 trechos);

b) a empresa define seu posicionamento estratégico para atuar em um novo local - CC 6 (21 trechos);

c) a combinação de recursos gerenciais da firma cria novos mercados - PM 7 (sete trechos);

d) a firma possui vantagem específica de propriedade de marcas - PE 1 (seis trechos);

e) a empresa define sua estratégia pela análise de concorrentes - CC 3 (cinco trechos);

f) o empreendedor (indivíduo) é o responsável pelo desenvolvimento de novos mercados EN 1; a empresa define sua estratégia pela análise de consumidores - CC 4; o conhecimento resulta do compartilhamento de experiências entre os membros da organização - CO 1; o conhecimento resulta do compartilhamento da aprendizagem entre os membros da organização - CO 2 (três trechos para cada proposição);

g) a cultura em determinado local interfere no processo de expansão da empresa - EU3; a empresa determina sua estratégia em função da excelência operacional - CC 1 (dois trechos em cada proposição);

h) a fase de introdução do produto é marcada pelo desenvolvimento de mercado - CP 4; a fase de crescimento do produto espalha a produção pelos países desenvolvidos - CP 6; a firma possui vantagem específica de propriedade da qualificação da mão-de-obra - PE3; a firma possui vantagem específica de localização de mercado - PE8; o idioma em determinado local interfere no processo de expansão da empresa - EU4; e a cultura de um país ou região interfere na cultura da organização - AI 1 (um trecho em cada proposição).

As proposições mais identificadas quando os entrevistados referiam-se à escolha do país estrangeiro para iniciar operação (223 trechos atribuídos a para onde ir e por que esse local) foram (Tabelas 7 e 8, p. 132-133; Gráfico 13):

a) a empresa define seu posicionamento estratégico para atuar em um novo local - CC 6 (72 trechos);

b) a empresa determina sua estratégia pela análise de oportunidades - CC 5 (48 trechos);

c) a empresa define sua estratégia pela análise de concorrentes - CC 3; a firma possui vantagem específica de localização de mercado - PE 8 (14 trechos em cada proposição); 
d) a empresa define sua estratégia pela análise de consumidores - CC 4; o idioma em determinado local interfere no processo de expansão da empresa - EU 4 (dez trechos em cada proposição);

e) a empresa determina sua estratégia pela análise de produtos - $\mathrm{CC} 2$; a firma adquire gradativamente conhecimento do local para o qual pretende se deslocar (aprendizagem) - EU 2 (nove trechos em cada proposição);

f) a cultura em determinado local interfere no processo de expansão da empresa - EU 3; a firma possui vantagem específica de propriedade de marcas - PE 1 (oito trechos em cada proposição);

g) a firma internacionaliza por meio de um processo gradual - EU 1; o relacionamento com os clientes em determinado local interfere no processo de expansão da empresa - EU 8; a empresa determina a sua estratégia em função da excelência operacional - CC 1 (três trechos em cada proposição);

h) a firma possui vantagem específica de localização de mão-de-obra - PE 6; o empreendedor (indivíduo) é o responsável pelo desenvolvimento de novos mercados - em 1; a firma escolhe a estrutura organizacional para atuar no mercado em função de sua rede de relacionamentos internacionais - EO 4 (dois trechos para cada proposição);

i) a empresa reduz a competição em países estrangeiros por meio de conluios ou fusões PM 1; a fase de crescimento do produto é marcada pela demanda estrangeira - CP 7; a firma possui vantagem específica de localização de infra-estrutura - PE 7; o relacionamento com os fornecedores em determinado local interfere no processo de expansão da empresa - EU 9; o relacionamento com os distribuidores em determinado local interfere no processo de expansão da empresa - EU 10; a firma escolhe a estrutura organizacional para atuar no mercado em função de suas características internas - EO 2 (um trecho em cada proposição). 


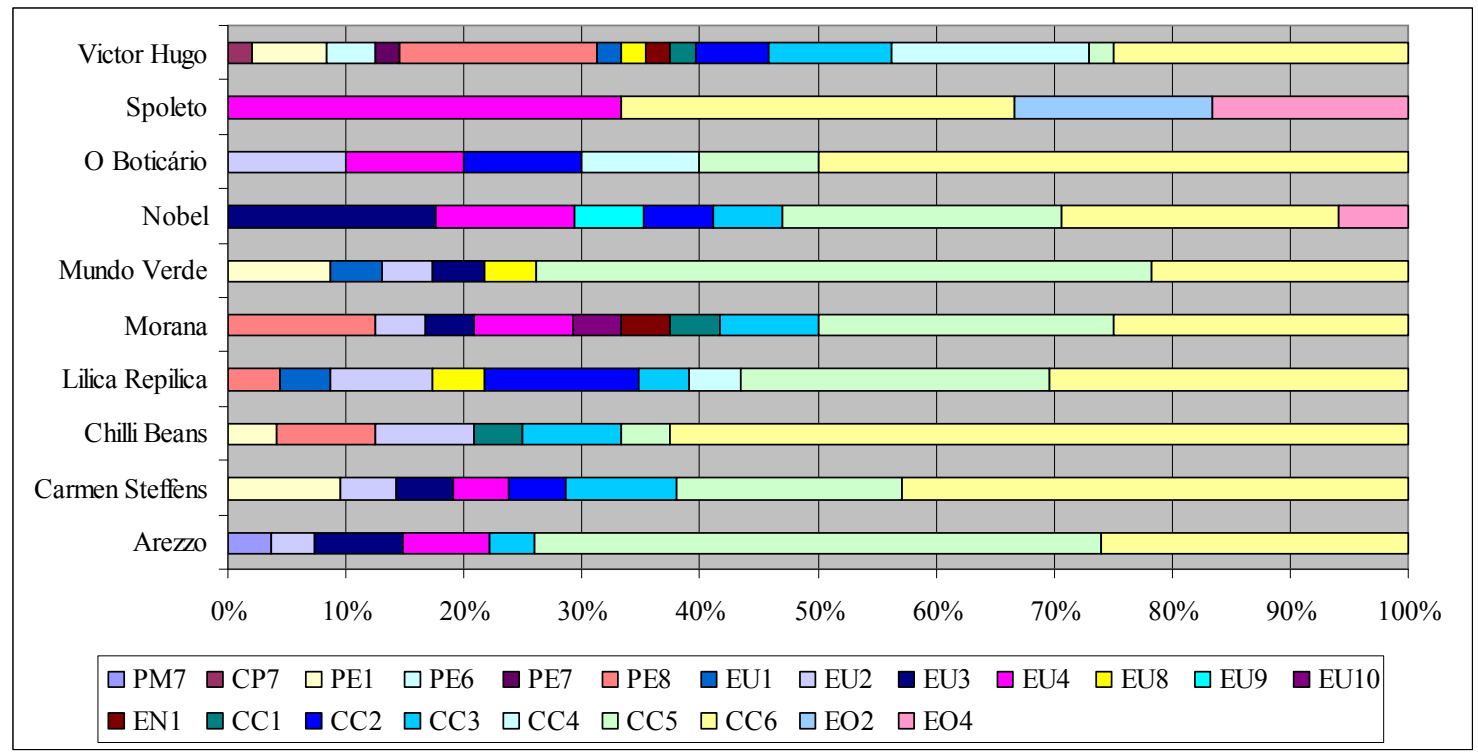

Gráfico 13 - Proposições e empresas: para onde ir

As proposições que mostraram maior quantidade de trechos relacionados à escolha do modo de entrada no novo local (302 trechos atribuídos a como entrar) foram (Tabelas de 9 a 12, p. 136-138; Gráfico 14):

a) a empresa define seu posicionamento estratégico para atuar em um novo local - CC 6 (105 trechos);

b) a firma adquire gradativamente conhecimento do local para o qual pretende se deslocar (aprendizagem) - EU 2 (36 trechos);

c) a firma internacionaliza por meio de um processo gradual - EU 1 (26 trechos);

d) a empresa determina sua estratégia pela análise de oportunidades - CC 5 (21 trechos);

e) a firma escolhe a estrutura organizacional para atuar no mercado em função de sua rede de relacionamentos internacionais - EO 4 (16 trechos);

f) a empresa tem a capacidade de disponibilizar as funções de operações - GC 3 (14 trechos);

g) a firma escolhe a estrutura organizacional para atuar no mercado em função de suas características internas - EO 2 (12 trechos);

h) o conhecimento resulta do compartilhamento de experiências entre os membros da organização - CO 1 (oito trechos);

i) a empresa reduz a competição em países estrangeiros por meio de conluios ou fusões -

PM 1; a firma integra a produção quando há incertezas de mercado - IN 5; a firma possui vantagem específica de propriedade de marcas - PE 1; o relacionamento com os 
distribuidores em determinado local interfere no processo de expansão da empresa - EU 10 (cinco trechos em cada proposição);

j) a firma integra a produção para vencer barreiras de entrada - IN 4; o relacionamento com os clientes em determinado local interfere no processo de expansão da empresa - EU 8; o conhecimento resulta do compartilhamento da aprendizagem entre os membros da organização - CO 2 (quatro trechos para cada proposição);

1) a cultura em determinado local interfere no processo de expansão da empresa - EU 3; o relacionamento com as agências reguladoras em determinado local interfere no processo de expansão da empresa - EU 11; a empresa determina sua estratégia pela análise de produtos CC2; a empresa define sua estratégia pela análise de concorrentes - CC 3; a empresa define sua estratégia pela análise de consumidores - CC 4 (três trechos em cada proposição);

m) a empresa controla outras empresas em países estrangeiros para usar o acesso aos fatores de produção (vantagem única) - 2; o empreendedor (indivíduo) é o responsável pelo desenvolvimento de novos mercados - EN 1; o indivíduo emprega sua rede de relacionamentos em novos mercados - EN 2; e a empresa tem a capacidade de desenvolver estratégias GC 2 (dois trechos para cada proposição);

n) a combinação de recursos gerenciais da firma cria novos mercados - PM 7; a firma integra a produção quando a especificidade dos ativos for grande - IN 3; a firma possui vantagem específica de propriedade da qualificação da mão-de-obra - PE 3; a firma possui vantagem específica de localização de mercado - PE 8; o idioma em determinado local interfere no processo de expansão da empresa - EU 4; o desenvolvimento do setor em determinado local interfere no processo de expansão da empresa - EU 7; a empresa determina sua estratégia em função da excelência operacional - CC 1; a firma escolhe a estrutura organizacional para atuar no mercado em função das características desse mercado - EO 1; os padrões de comportamento de um grupo influenciam a gestão da empresa - AI 5 (um trecho para cada proposição). 


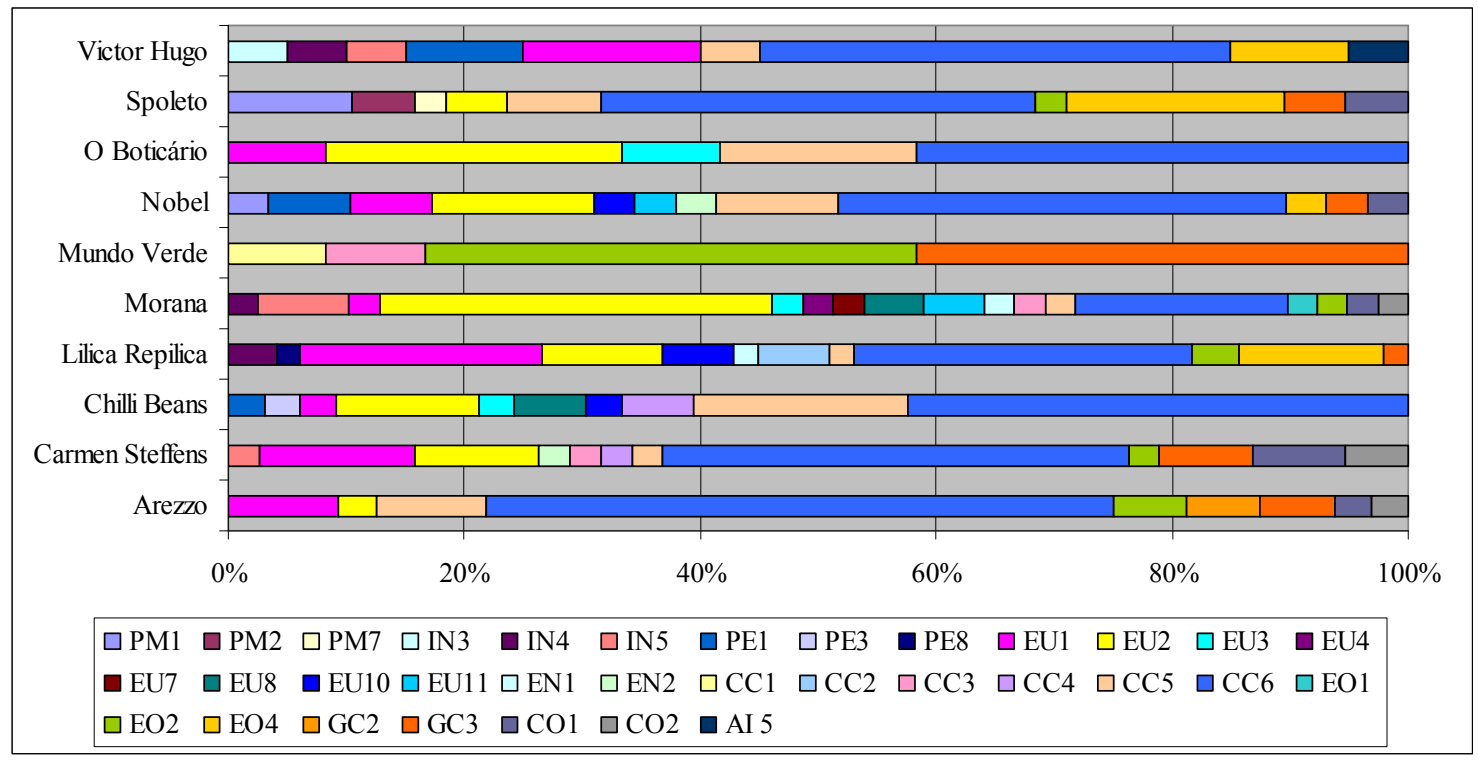

Gráfico 14 - Proposições e empresas: como entrar

As proposições que apresentaram maior número de registros relativos às adaptações feitas nos países estrangeiros (289 trechos relacionados a como se adaptar) foram (Tabelas de 13 a 15, p. 142-143; Gráfico 15):

a) a firma adquire gradativamente conhecimento do local para o qual pretende se deslocar (aprendizagem) - EU 2 (59 trechos);

b) o conhecimento resulta do compartilhamento de experiências entre os membros da organização - CO 1 (33 trechos);

c) a empresa tem a capacidade de disponibilizar as funções de operações - GC 3 (29 trechos);

d) a firma escolhe a estrutura organizacional para atuar no mercado em função de suas características internas - EO 2 (24 trechos);

e) a empresa define seu posicionamento estratégico para atuar em novo local - CC 6 (23 trechos);

f) o conhecimento resulta do compartilhamento da aprendizagem entre os membros da organização - CO 2 (16 trechos);

g) a empresa determina sua estratégia pela análise de oportunidades - CC 5; a firma escolhe a estrutura organizacional para atuar no mercado em função das características desse mercado - EO 1 (15 trechos em cada proposição);

h) as práticas de negócio em determinado local interferem no processo de expansão da empresa - EU 6 (12 trechos); 
i) o relacionamento com os clientes em determinado local interfere no processo de expansão da empresa - EU 8 (nove trechos);

j) a firma escolhe a estrutura organizacional para atuar no mercado em função de sua rede de relacionamentos internacionais - EO 4 (seis trechos);

1) a firma internacionaliza por meio de um processo gradual - EU 1; a empresa determina sua estratégia pela análise de produtos - CC 2; a empresa tem a capacidade de aprender com o ambiente - GC 1 (cinco trechos para cada proposição);

m) a fase de crescimento do produto espalha a produção pelos países desenvolvidos - CP 6; o relacionamento com as agências reguladoras em determinado local interfere no processo de expansão da empresa - EU 11 (quatro trechos para cada proposição);

n) a cultura em determinado local interfere no processo de expansão da empresa - EU 3; a empresa define sua estratégia pela análise de consumidores - CC 4 (três trechos em cada proposição);

o) a empresa tem a capacidade de desenvolver estratégias - GC 2; a cultura de um país ou região interfere na cultura da organização - AI 1 (dois trechos em cada proposição);

p) a fase de crescimento do produto inicia a difusão da tecnologia - CP 8; a firma integra a produção quando a especificidade dos ativos é grande - IN 3; a firma possui vantagem específica de propriedade de marcas - PE 1; o idioma em determinado local interfere no processo de expansão da empresa - EU 4; o relacionamento com os fornecedores em determinado local interfere no processo de expansão da empresa - EU 9; a empresa determina sua estratégia em função da excelência operacional - CC 1; a empresa define sua estratégia pela análise de concorrentes - CC 3; a firma escolhe a estrutura organizacional para atuar no mercado em função de sua habilidade de gerenciar além-fronteiras - EO 3; a empresa tem a capacidade de disponibilizar as funções de operações - GC 3 (um trecho para cada proposição). 


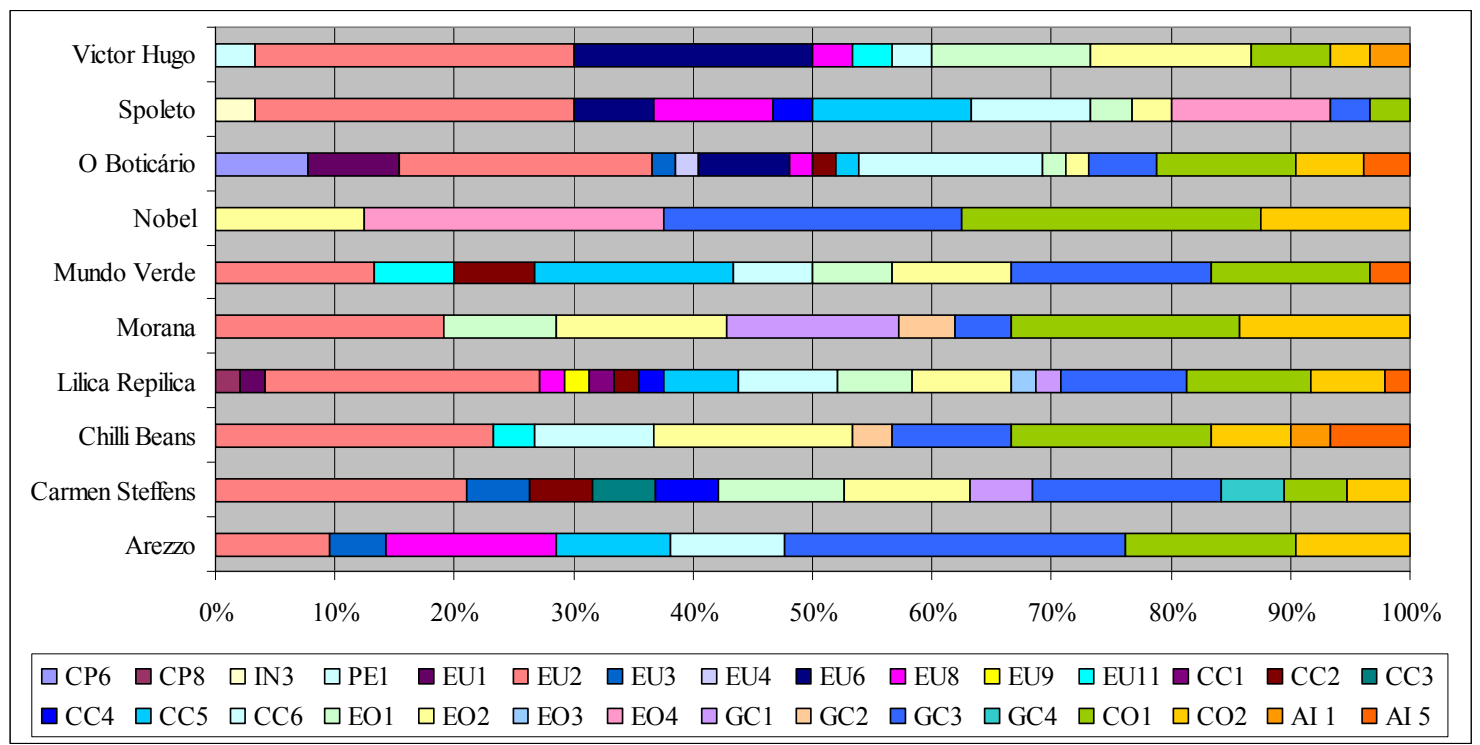

Gráfico 15 - Proposições e empresas: como se adaptar

\subsection{Síntese - teorias e empresas}

Ao analisar o discurso dos gestores das dez empresas de varejo brasileiras, pôde-se identificar que a Teoria sobre Competição e Competitividade Global e a Escola de Uppsala estão mais relacionados aos processos de internacionalização dessas empresas. Em seguida, destacam-se a Abordagem sobre Gestão Estratégica de Operações, Abordagem sobre Gestão do Conhecimento e Abordagem sobre Gestão de Competências. Apesar disso, a Abordagem sobre Gestão de Competências não foi verificada no discurso do gestor da empresa Victor Hugo. O Paradigma Eclético não foi identificado em duas entrevistas: Spoleto e O Boticário. A Teoria do Ciclo do Produto foi percebida em metade das entrevistas: Lilica Ripilica, Morana, Nobel, O Boticário e Victor Hugo. A Teoria do Poder de Mercado incidiu no discurso dos gestores de sete empresas: Arezzo, Carmen Steffens, Morana, Nobel, O Boticário, Spoleto e Victor Hugo. A Teoria de Internalização foi identificada nas entrevistas da Carmen Steffens, Lilica Ripilica, Morana, Spoleto e Victor Hugo. A estrutura teórica da Escola de Nórdica foi verificada nas entrevistas da Carmen Steffens, Lilica Ripilica, Morana, Nobel e Victor Hugo. Já a Abordagem Intercultural não foi identificada no discurso dos gestores da Arezzo, Carmen Steffens, Nobel e Spoleto. Um aspecto que se destaca é que apenas a Morana mostrou trechos relacionados a todas as estruturas teóricas consideradas nesta pesquisa. 


\subsection{Considerações finais}

Por meio da pesquisa de campo foi possível detectar as teorias que mais contribuíram com registros para as entrevistas analisadas em sua totalidade. $\mathrm{O}$ tamanho de cada entrevista, mais ou menos longa, não tem relação direta com a quantidade de trechos que podem ser selecionados e relacionados ao tema da internacionalização de empresas, pois cada uma delas pode conter muitos trechos redundantes, elementos de função fática, manifestações de ufanismo, entre outros, que devem ser excluídos durante a preparação do texto na Análise de Conteúdo. Obteve-se a seguinte distribuição para um total de 912 ocorrências:

- $\quad$ Teoria sobre Competição e Competitividade Global (408);

- $\quad$ Escola de Uppsala (211);

- $\quad$ Abordagem sobre Gestão Estratégica de Operações (78);

- $\quad$ Abordagem sobre Gestão do Conhecimento (67);

- $\quad$ Abordagem sobre Gestão de Competências (53);

- $\quad$ Paradigma Eclético (41);

- $\quad$ Teoria do Poder de Mercado (16);

- $\quad$ Teoria de Internalização (11)

- $\quad$ Abordagem Intercultural (10);

- $\quad$ Escola Nórdica (9);

- $\quad$ Teoria do Ciclo do Produto (8).

Há duas formas de avaliar a contribuição de cada teoria ou abordagem no processo de internacionalização das empresas de varejo pesquisadas. A primeira é observar a quantidade de trechos para cada teoria em cada etapa do processo e em relação ao total de trechos relacionados com o tema; a segunda é identificar a contribuição em termos da quantidade de trechos por etapa do processo em relação ao total de trechos classificados para cada uma das teorias. Essa segunda modalidade avalia cada teoria independentemente e mostra em que etapas do processo de internacionalização incidiu de maneira mais intensa.

Para a primeira forma de análise a Teoria sobre Competição e Competitividade Global apresentou maior participação em relação ao total de trechos relacionados ao tema da internacionalização de empresas. A essa teoria seguiu-se a Escola de Uppsala, Abordagem sobre Gestão Estratégica de Operações, Abordagem sobre Gestão do Conhecimento, Abordagem sobre Gestão de Competências, Paradigma Eclético, Teoria do Poder de Mercado, 
Teoria de Internalização, Abordagem Intercultural, Escola Nórdica e Teoria do Ciclo do Produto.

Quando se faz a avaliação levando em conta a contribuição de cada teoria de forma independente e por etapa do processo de internacionalização das empresas de varejo estudadas, percebe-se que as teorias ou abordagens mais relacionadas às razões que levaram a empresa a se internacionalizar são Abordagem Intercultural, Ciclo do Produto, Escola Nórdica, Paradigma Eclético e Poder de Mercado. Verifica-se que em relação à escolha do país estrangeiro a Teoria sobre Competição e Competitividade Global e o Paradigma Eclético estiveram mais presentes. No relato do momento em que as empresas tiveram de definir o modo de operação no novo país, a Escola Nórdica, a Teoria de Internalização e Teoria do Poder de Mercado tiveram maior incidência. Depois de iniciada a atuação no país estrangeiro, as empresas de varejo estudadas passaram por uma fase de adaptação de suas operações. As teorias ou abordagens que mais se relacionam com essa fase são Abordagem Intercultural, Teoria do Ciclo do Produto, Escola de Uppsala, Abordagem sobre Gestão de Competências, Abordagem sobre Gestão do Conhecimento e Abordagem sobre Gestão Estratégica de Operações.

Tabela 16 - Processo de Internacionalização

\begin{tabular}{|c|c|c|c|c|c|}
\hline \multirow{2}{*}{ Teorias } & \multicolumn{5}{|c|}{ Processo de Internacionalização } \\
\cline { 2 - 6 } & Por que sair & Para onde ir & $\begin{array}{c}\text { Como entrar } \\
\text { no novo local }\end{array}$ & $\begin{array}{c}\text { Como se adaptar } \\
\text { ao novo local }\end{array}$ & $\begin{array}{c}\text { Total por } \\
\text { teoria }\end{array}$ \\
\hline Abordagem Intercultural & 1 & 0 & 1 & 8 & 10 \\
\hline Ciclo do Produto & 2 & 1 & 0 & 5 & 8 \\
\hline $\begin{array}{c}\text { Competição e } \\
\text { Competitividade Global }\end{array}$ & 68 & 156 & 136 & 48 & 408 \\
\hline Escola de Uppsala & 3 & 35 & 79 & 94 & 211 \\
\hline Escola Nórdica & 3 & 2 & 4 & 0 & 9 \\
\hline Gestão de Competências & 0 & 0 & 16 & 47 & 53 \\
\hline Gestão do Conhecimento & 6 & 0 & 12 & 46 & 78 \\
\hline Gestão Estratégica de & 0 & 3 & 29 & 1 & 11 \\
\hline Operações & 0 & 0 & 10 & 1 & 41 \\
\hline Internalização & 8 & 25 & 7 & 0 & 16 \\
\hline Paradigma Eclético & 7 & 1 & 8 & & 79 \\
\hline Poder de Mercado & & & & & \\
\hline
\end{tabular}

A Tabela 16 sintetiza a maneira como as teorias sobre internacionalização participaram nos discursos dos gestores das empresas de varejo pesquisadas, além de resumir a freqüência das proposições por teoria, também ilustrada no Gráfico 16. 


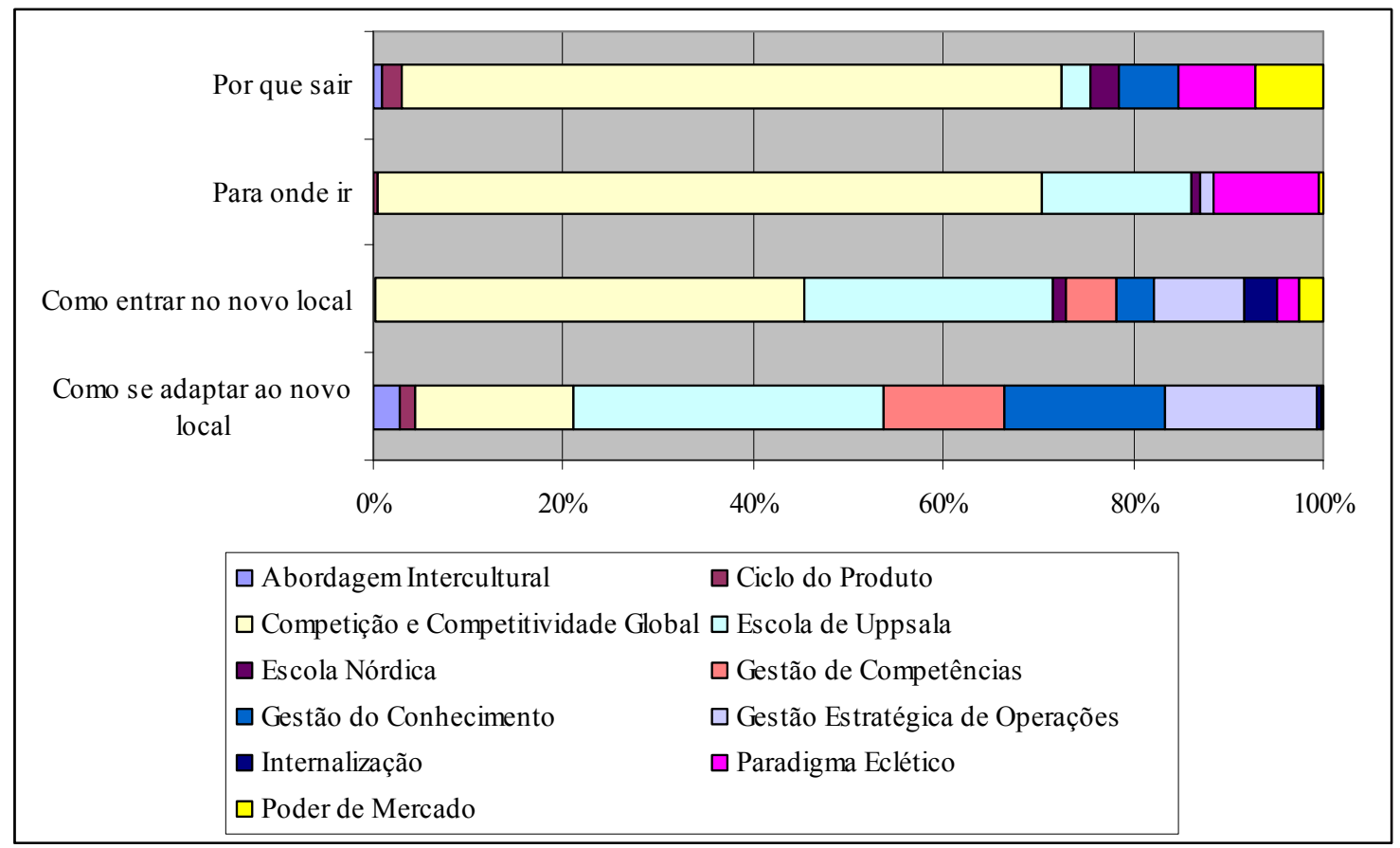

Gráfico 16 - Processo de Internacionalização

A Taxonomia de Encadeamento Teórico proposta para as teorias relacionadas à internacionalização de empresas apresenta, além das estruturas teóricas, os fatores de risco abordados por Loureiro (1990): políticos, econômicos (incluindo cambiais), sociais, culturais, regulatórios (legislativos e jurídicos), ambientais, comerciais (competitivos e estratégicos) e financeiros. Nas entrevistas em profundidade foram encontrados todos os fatores, com exceção do fator ambiental, como se pode ver na Ilustração 22.

Principalmente, um fator influenciou a internacionalização das empresas estudadas: a abertura de mercado decorrente do Plano Collor, em 1990. Esse fator, segundo a literatura, é um fator que empurra ou push factor. Parece também ter relação com a estrutura proposta por Eckert e Mayrhofer (2005), que chamam a atenção para a existência de três categorias para dividir o processo de internacionalização de cada empresa: evolução internacional, episódios internacionais e épocas internacionais. Nesse sentido, o Plano Collor poderia ser classificado como um marco histórico que acabou propiciando o início da evolução das empresas brasileiras de varejo em mercados estrangeiros. 


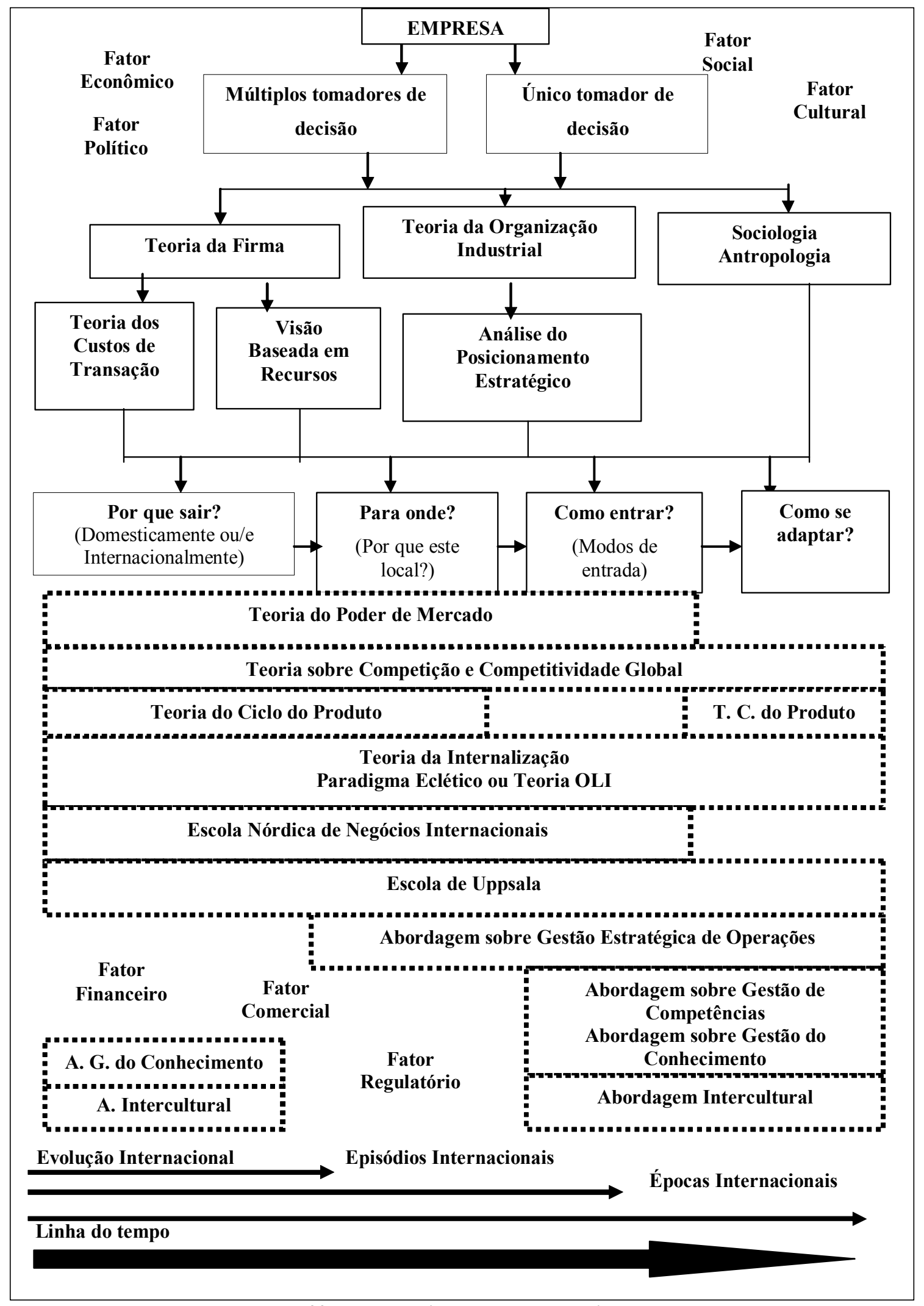

Ilustração 22 - Taxonomia resultado da análise dos dados 
As estruturas teóricas que os autores pesquisados destacam para explicar o processo de internacionalização de empresas de varejo não foram identificadas de maneira idêntica nas empresas pesquisadas. A análise das entrevistas resulta em uma relação de teorias sobre internacionalização de varejo mais ampla do que a apresentada pelos autores da área. Os autores pesquisados destacam que há ligação dos processos de internacionalização com a Análise do Posicionamento Estratégico, o Paradigma Eclético (Teoria OLI) e a Escola de Uppsala. Porém, todas as teorias e abordagens foram identificados nos discursos do gestores das dez empresas. $O$ fato parece reforçar a necessidade de avaliar o processo de internacionalização de empresas de varejo, empregando um referencial teórico mais abrangente, ou seja, aquele que vem sendo usado nos estudos de empresas de outros ramos de atividade. Porém, o fato de dez empresas comporem a amostra desta tese é insuficiente para desqualificar a Taxonomia. Sugere-se, então, ampliar a amostra de empresas de varejo a serem estudadas sob essa ótica.

\subsection{Limitações do estudo e sugestão para pesquisas futuras}

A pesquisa sobre internacionalização de empresas registrada nesta tese apresenta limitações relacionadas ao tamanho da amostra e à metodologia empregada. Contudo, indagações decorrentes da análise do fenômeno abordado e dos resultados encontrados neste trabalho podem sugerir questões complementares para estudos futuros. Sugere-se ampliar a quantidade de empresas de varejo pesquisadas, aplicando-se a Análise de Conteúdo; testar a Taxonomia aqui proposta por meio de pesquisa quantitativa e ainda desenvolver estudos focalizando cada uma das teorias, abordagens ou enfoques para que se possa aprofundar a investigação sobre as questões inerentes ao processo de interancionalização de empresas de varejo e a construção de estrutura teórica própria para o setor. 


\section{REFERÊNCIAS}

ALEXANDER, Nicholas. Internationalization: interpreting the motives. In: MCGOLDRICK, Peter; DAVIES, Gary (Ed.). International retailing: trends and strategies. London: Pitman Publishing, 1995.

.; MYERS, Hayley. The retail internationalisation process. International Marketing Review. London, v. 17, n. 4/5, p. 334, 2000. Disponível em: <http://proquest.umi.com/pqdweb>. Acesso em: 15/4/2007.

.; SILVA, Marcelo de Lira e. Emerging markets and the internationalisation of retailing: the Brazilian experience. International Journal of Retail \& Distribution Management. [S.1.]: MCB UP, v. 30, n. 6, p. 300-314, 2002. Disponível em: $<$ http://proquest.umi.com/pqdweb>. Acesso em: 18/1/2007.

ANDERSEN, Otto. On the internationalization process of firms: a critical analysis. Journal of International Business Studies. [S.1.], v. 24, n. 2, p. 209, 2nd quarter, 1993. Disponível em: $<$ http://proquest.umi.com/pqdweb?index $=$ O\&did $=582903 \&$ SrchMode $=2 \&$ Sid $=4 \mathrm{Fmt}=6 \&$ Vlnst=PROD\&VType=PQD\&RQT=309\&VName=PQD\&TS=1231773891\&clientld=18113. Acesso em: 12/1/2009.

AREZZO. Disponível em: <http://www.arezzo.com.br/primaveraVerao/2009/altoverao2009/ home.html>. Acesso em: 25/1/2009.

AXINN, Catherine; MATTHYSSENS, Paul. Viewpoint: limits of internationalization theories in an unlimited world. International Marketing Review. [S.1.]: MCB University Press, v. 19, n. 5, p. 436-449, 2002. Disponível em: <http://proquest.umi.com/pqdweb>. Acesso em: $11 / 4 / 2007$.

BAIN, Joe Staten. Industrial organization. [S.1.]: Wiley \& Sons, 1959.

BARDIN, Laurence. Análise de conteúdo. Tradução de Luís Antero Reto e Augusto Pinheiro. 3. ed. Lisboa: Edições 70, 2004.

BARKEMA, Harry G.; BELL, John H. J.; PENNINGS, Johannes M. Foreign entry, cultural barriers, and learning. Strategic Management Journal. [S.1.], v. 17, n. 2, p. 151, 1996. Disponível em: <http://publishing.eur.nl/ir/repub/asset/12833/20070627_051.pdf>. Acesso em: 10/1/2009.

.; ROCHA, Angela da. A expansão das fronteiras: brasileiros no exterior. In: ROCHA, Ângela da (Org.). As novas fronteiras: a multinacionalização das empresas brasileiras. Coleção Estudos COPPEAD. Rio de Janeiro: Mauad, 2003.

BARTLETT, Christopher A.; GHOSHAL, Sumantra. Organizing for worldwide effectiveness: the transnational solution. California Management Review. [S.1.], fall, 1988. 
BELL, Jim. The internationalization of small computer software firms: a further challenge to "stage" theories. European Journal of Marketing. [S.1.], v. 29, n. 5, p. 60, 1995. Disponível em: $\quad<$ http://proquest.umi.com/pqd?index $=3 \&$ did $=12135872 \&$ SrchMode $=2 \&$ sid $=20 \&$ Fmt $=6$ $\&$ Vlnst $=$ PROD\&VType $=$ PQD\&RQT $=309 \&$ VName $=$ PQD\&TS $=1231696157 \&$ clintld $=18113$ $>$. Acesso em: 11/1/2009.

BLASIUS, Jörg; GREENACRE, Michael. Visualization of categorical data. San Diego, Califórnia (USA): Academic Press, 1998.

BLOMSTERMO, Anders; SHARMA, D. Deo (Ed.). Three decades of research on the internationalisation process of firms. In: Learning in the internationalization process of firms. UK: Edward Elgar, 2003.

BORINI, Felipe Mendes et al. O prisma da internacionalização. In: VII SEMEAD, 2004. Disponível em: < http://www.ead.fea.usp.br>. Acesso em: 21/1/2007.

BROWN, Stephen; BURT, Steve. Conclusion - Retail internationalization: past imperfect, future imperative. European Journal of Marketing. [S.1.; s.n.], v. 26, n. 8/9, p. 80, 1992. Disponível em: <http://proquest.umi.com/pqdweb>. Acesso em: 15/4/2007.

BUCKLEY, Peter J. Problems and developments in the core theory of international business. Journal of International Business Studies. [S.1.], v. 21, n. 4, 4th quarter, 1990.

.; CASSON, Mark. The future of the multinational enterprise: $25^{\text {th }}$ anniversary. 2nd ed. New York: Palgrave Macmillan, 2002.

BURT, Steve. Retail internationalisation: evolution of theory and practice. In: MCGOLDRICK, Peter; DAVIES, Gary (Ed.). International retailing: trends and strategies. London: Pitman Publishing, 1995. Disponível em: <http://proquest.umi.com/pqdweb $>$. Acesso em: $13 / 10 / 2007$.

CARMEN STEFFENS. Disponível em: <http://www.carmensteffens.com.br/2009/web/ index.html>. Acesso em: 25/1/2009.

CAVUSGIL, S. Tamer. Organizational characteristics associated with export activity. Journal of Management Studies. [S.1.], v. 21, n. 1, 1984. Disponível em: <http://ux3bu4ijh2n. search.serialssolutions.com/directlink? \&atitle=Organizational\%20Characteristics\%20Associa ted $\% 20$ with $\% 20$ Export $\% 20$ Activity\&author=Cavusgil $\% 2 \mathrm{c} \% 20 \mathrm{~S} \% 20$ Tamer\&issn $=00222380$ \&title $=$ The $\% 20$ journal $\% 20$ of $\% 20$ Studies $\&$ volume $=21 \&$ issue $=1 \&$ date $=19840101 \&$ spage $=3 \&$ $\mathrm{id}=$ doi:\&sid=PROQ_SS\&genre=article\&long=pt $>$. Acesso em: 12/1/2009.

CERCEAU, Júnia; LARA, José Edson. Estratégias de internacionalização de empresas: uma abordagem teórica. In: ENANPAD, ANPAD, 1999. Disponível em: < http://wwwenanpad.anpad.org.org.br/enanpad/1999-ae-23.pdf>. Acesso em: 13/1/2008. 
CHILLI BEANS. Disponível em: <http://www.chillibeans.com.br/quem_somos.asp >. Acesso em: $24 / 1 / 2009$.

CLAUSEN, Sten-Erik. Applied correspondence analysis: an introduction. Sage Publications. Thousand Oaks, California, USA, 1998. Series: Quantitative Applications in the Social Sciences.

COASE, R. H. The nature of the firm: origins (1937). In: WILLIAMSON, O. E.; WINTER, S. G. (Ed.). The nature of the firm: origins, evolution and development: 34-47. Oxford: Oxford University Press, 1993.

. The nature of the firm (1937). In: WILLIAMSON, O. E.; WINTER, S. G. (Ed.). The nature of the firm: origins, evolution, and development: 18-33. Oxford: Oxford University Press, 1997.

CYERT, Richard M.; MARCH, James G. A behavioral theory of the firm. 2nd ed. USA: Blackwell Publishing, 1992.

CYRINO, Álvaro B.; BARCELLOS, Érika Penido. Estratégias de internacionalização: evidências e reflexões sobre as empresas brasileiras. In: TANURE, Betania; DUARTE, Roberto Gonzalez (Org.). Gestão internacional. São Paulo: Ed. Saraiva, 2006.

. Benefícios, riscos e resultados do processo de internacionalização das empresas brasileiras. In: ALMEIDA, André (Org.). Internacionalização de empresas brasileiras: perspectivas e riscos. Rio de Janeiro: Elsevier, 2007.

DUNNING, John H. The ecletic paradigm of international production: a restatement and some possible extensions. Journal of International Business Studies. [S.1.], autumn, 1988.

. FDI, globalisation and development: some implications for Brazilian firms and Brazilian policy makers. In: V WORKSHOP EM INTERNACIONALIZAÇÃO DE EMPRESAS, 2005. Disponível em: <www.coppead.ufrj.br/workshop/>. Acesso em: 21/1/2007.

DUROZOI, Gerard; ROUSSEL, André. Dicionário de filosofia. Tradução Marina Appenzeller. 2. ed. Campinas, SP: Papirus, 1996.

ECKERT, Stefan; MAYRHOFER, Ulrike. Identifying and explaining epochs of internationalization: a case study. European Management Review. [S.1.], v. 2, p. 212-223, 2005. Disponível em: <http://proquest.umi.com/pqdweb>. Acesso em: 18/1/2007. 
EROGLU, Sevgin. The Internationalization process of franchise systems: a conceptual model. International Marketing Review. [S.1.], v. 9, n. 5, p. 19, 1992. Disponível em: $<$ http://proquest.umi.com/pqdweb? index $=$ O\&did $=547223 \&$ SrchMode $=2 \&$ sid $=3 \& F m t=3 \& \mathrm{Vl}$ nst=PROD\&Vtype=PQD\&RQT=309\&Vname=PQD\&TS=1231773651\&clientld=18113>.

Acesso em: 12/1/2009.

EVANS, Jody et al. Psychic distance and the performance of international retailers: a suggested theorethical framework. International Marketing Review. London, v. 17, n. 4/5, p. 373, 2000. Disponível em: <http://proquest.umi.com/pqdweb>. Acesso em: 15/4/2007.

EVANS, Jody; MAVONDO, Felix T. Psychic distance and organizational performance: an empirical examination of international retailing operations. Journal of International Business Studies. [S.1.], v. 33, n. 3, p. 515-532, 3rd quarter, 2002. Disponível em: <http: //proquest.umi.com/pqdweb>. Acesso em: 15/4/2007.

FISCHER, André Luiz; EBOLI, Marisa. Management development as a competitive strategy: a study of policies and practices of management competences in Brazilian companies in a competitive era. Management Research News. [S.1.], v. 23, n. 2/3/4, 2000. Disponível em: $<$ http://proquest.umi.com/pqdweb $>$. Acesso em: 18/1/2007.

FLEURY, Afonso; FLEURY, Maria Tereza Leme. Estratégias competitivas e competências essenciais: perspectivas para a internacionalização da indústria no Brasil. Gestão \& Produção, v. 10, n. 2, p. 129-144, agosto, 2003.

. Estratégias empresariais e formação de competências: um quebra-cabeça caleidoscópico da indústria brasileira. São Paulo: Atlas, 2004.

. Competitiveness, competences and corporate strategies: Brazil and China catching$\overline{u p}$ in the global economy. In: THIRD INTERNATIONAL WORKSHOP "GLOBALIZATION AND CORPORATE STRATEGIES FOR THE XXI CENTURY: THE BRAZILIAN INNOVATION CHALLENGE”. November, 2005.

. Para pensar o processo de internacionalização das empresas brasileiras. Inova Gestão e Tecnologia - Boletim do Núcleo de Política e Gestão Tecnológica da Universidade de São Paulo. Ano XIII, n. 45, Jan./Fev./Mar., 2006. Disponível em: $<$ http://fundacaofia.com.br/pgtusp/>. Acesso em: 23/4/2007.

FORD, David. Viewpoint - Distribution, internationalisation and networks: solving old problems, learning new things and forgetting most of them. International Marketing Review. [S.1.]: MCB UP, v. 19, n. 3, p. 225-235, 2002. Disponível em: $<$ http://proquest.umi.com/pqdweb>. Acesso em: 16/4/2007.

GUEDES, Ana Lucia. Negócios internacionais. Coleção Debates em Administração. São Paulo: Thomson Learning, 2007. 
GRIPSRUD, Geir; BENITO, Gabriel R. G. Internationalization in retailing: modeling the pattern of foreign market entry. Journal of Business Research. [S.1.], v. 58, n. 12, p. 1.6721.680, December, 2005.

GOUVEA NETO, Raul de. Mercosur: fostering regional economic integration. Thunderbird International Business Review. [S.1.], v. 40, n. 6, p. 585-604, 1998. Disponível em: $<$ http://proquest.umi.com/pqdweb $>$. Acesso em: 18/1/2007.

GUPTA, Anil K.; GOVINDARAJAN, Vijay. Knowledge flows and the structure of control within multinational corporations. The Academy of Management Review. [S.1.], v. 16, n. 4, p. 768, Oct., 1991.

HAIR Jr., Joseph F. et al. Multivariate data analysis. 5th ed. New Jersey, USA: PrenticeHall, 1998.

. Análise multivariada de dados. Tradução de Adonai Schlup Sant'Ana. CHAVES NETO, Anselmo (Org.). 5. ed. Porto Alegre, Brasil: Bookman, 2005.

HEMAIS, Carlos A.; HILAL, Adriana. Teorias, paradigmas e tendências em negócios internacionais: de Hymer ao empreendedorismo. In: HEMAIS, Carlos A. (Org.). O desafio de mercados externos: teoria e prática na internacionalização da firma. V. 1. Coleção Estudos COPPEAD. Rio de Janeiro: Mauad, 2004.

HILAL, Adriana; HEMAIS, Carlos A. O processo de internacionalização na ótica da Escola Nórdica: evidências empíricas em empresas brasileiras. RAC. [S.1.], v. 7, n. 1, p. 109-124, jan/mar, 2003. Disponível em: <www.anpad.org.br>. Acesso em: 18/1/2007.

HILL, Charles W. L. et al. An eclectic theory of the choice of international entry mode. Strategic Management Journal. [S.1.], v. 11, n. 2, p. 117, Feb., 1990. Disponível em: $<$ http://proquest.umi.com/pqdweb?index $=1 \& \mathrm{did}=809706 \&$ SrchMode $=2 \&$ sid $=1 \&$ Fmt $=6 \&$ Vln $\mathrm{st}=\mathrm{PROD} \& \mathrm{VType}=\mathrm{PQD} \& \mathrm{RQT}=309 \& \mathrm{VName}=\mathrm{PQD} \& \mathrm{TS}=1231773394 \& \mathrm{clientld}=18113>$.

Acesso em: 12/1/2009.

HITT, Michael A. et al. Administração estratégica. Tradução de José Carlos Barbosa Santos e Luiz Antonio Pedroso Rafael. São Paulo: Pioneira Thompson Learning, 2002.

HIRSCH, Seev. The United States electronic industry in international trade. National Institute Economic Review. [S.1.], v. 34, p. 92-97, may, 1965.

. An international trade and investment theory of the firm. Oxford Economic Papers, New Series, v. 28, n. 2, p. 258-270, Jul., 1976. Disponível em: <http://www.jstor.org>. Acesso em 10/2/2008.

HOFSTEDE, Geert. Culturas e organizações: compreender a nossa programação mental. Tradução António Fidalgo. Lisboa: Sílabo, 2003. 
HOLLANDER, Stanley C. Multinational retailing. East Lansing, USA: Michigan State University, 1970.

Distringuished retrospective viewpoint: study retailing and see the world? International Marketing Review. London, v. 17, n. 4/5, p. 327, 2000.

HORAGUCHI, Haruo; TOYNE, Brian. Setting the record straight: Hymer, internalization theory and transaction cost economics. Journal of International Business Studies. [S.1.], v. 21, n. 3, p. 487-494, 3rd quarter, 1990. Disponível em: <http://proquest.umi.com/pqdweb>. Acesso em: 13/10/2007.

HYMER, Stephen. The efficiency (contradictions) of multinational corporations. The American Economic Review. Papers and Proceedings of the Eighty-second Annual Meeting of the American Economic Association. [S.1], v. 60, n. 2, p. 441-448, May, 1970. Disponível em: <http://www.jstor.org/stable/pdfplus/1815843.pdf>. Acesso em: 4/10/2008.

The international operations of national firms: a study of direct foreign investment. Cambridge, MA: MIT Press, 1976.

. Empresas multinacionais: a internacionalização do capital. Tradução de Aloísio Teixeira. 2. ed. Rio de Janeiro: Graal, 1983.

JAPIASSÚ, Hilton; MARCONDES, Danilo. Dicionário básico de filosofia. 3. ed. Rio de Janeiro: Jorge Zahar, 1999.

JOHANSON, Jan; WIEDERSHEIM-PAUL, Finn. The internationalization of the firm: four Swedish cases. The Journal of Management Studies. [S.1.], v. 12, Issue 3, Oct., 1975. Disponível em: $<$ http://web.ebscohost. com/ehost/pdf $>$. Acesso em: 10/2/2008.

JOHANSON, Jan; VAHLNE, Jan-Erik. The internationalization process of the firm: a model of knowledge development and increasing foreign market commitments. Journal of International Business Studies (pre-1986). [S.1.], v. 8, p. 23-32, spring, 1977. Disponível em: <http://proquest.umi.com/pqdweb>. Acesso em: 15/10/2007.

The mechanism of internationalisation. International Marketing Review. London,

v. 7, n. 4, p. 11, 1990. Disponível em: <http://proquest.umi.com/pqdweb>. Acesso em: $11 / 4 / 2007$.

KNIGHT, Gary A.; CAVUSGIL, S. Tamar. Innovation, organizational capabilities, and the born-global firm. Journal of International Business Studies. [S.1], v. 35, p. 124-141, Jan., 2004. Disponível em: <http://proquest.umi.com/pqdweb>. Acesso em: 19/11/2007.

KRIPPENDORFF, Klaus. Content analysis: an introduction to its methodology. 2nd ed. USA: Sage Publications, 2004. 
KUTSCHKER, Michael; BÄURLE, Iris. Three + one: multidimensional strategy of internationalization. Management International Review. [S.1.], v. 37, n. 2, p. 103-125, 2nd quarter, 1997. Disponível em: <http://proquest.umi.com/pqdweb>. Acesso em: 9/10/2007.

KWOK, Chuck C. Y.; REEB, David M. Internationalization and firm risk: an upstreamdownstream hypothesis. Journal of International Business Studies. [S.1.], v. 31, n. 4, p. 611, 4th quarter, 2000. Disponível em: $<$ http://proquest.umi.com/pqdweb?index=O\&did=65959951\& SrchMode $=2 \&$ sid $=22 \&$ Fmt $=6 \&$ Vlnst $=$ PROD $\&$ Vtype $=$ PQD \&RQT $=309 \& V$ Name $=$ PQD $\& T S=123169$ 6971\&clientld=18113>. Acesso em: 11/1/2009.

LEUNG, Kwok et al. Culture and international business: recent advances and their implications for future research. Journal of International Business Studies. [S.1.], v. 36, p. 357-378, 2005. Disponível em: <http://proquest.umi.com/pqdweb>. Acesso em: 9/9/2007.

LOUREIRO, Fernando Augusto de Andrade Vieira. Internacionalização de empresas: estratégias e ação. São Paulo, 1990. Dissertação (Mestrado em Administração) - Faculdade de Economia, Administração e Contabilidade da Universidade de São Paulo.

LYLES, Marjorie A.; SALK, Jane E. Knowledge acquisition from foreign parents in international joint-ventures: an empirical examination in the Hungarian context. Journal of International Business Studies. [S.1.], v. 27, n. 5, p. 877, 1996.

MARISOL. Disponível em: <http://www.marisolsa.com.br/pt/>. Acesso em 24/1/2009.

MCGOLDRICK, Peter J. Introduction to international retailing. In: (Ed.). International retailing: trends and strategies. London: Pitman Publishing, 1995. .; DAVIES, Gary

MELlO, Sérgio C. Benício de et al. Country-of-origin: a imagem de um país e como ela reflete nos seus produtos e serviços. Disponível em: <www.angrad.org.br>. Acesso em: $18 / 1 / 2007$.

MORANA. Disponível em: <http:/www.grupoornatus.com/grupo-ornatus/>. Acesso em: 24/1/2009.

MUNDO VERDE. Disponível em: <http://www.mundoverde.com.br/2008/Institucional Historia.asp>. Acesso em: 25/1/2009.

NEUENDORF, Kimberly A. The content analysis guidebook. 2nd ed. USA: Sage Publications, 2002.

NOBEL. Disponível em: <http:/www.livrarianobel.com.br/cgi-bin/nobelBR.storefront/ 497cd76a0474601a273fc8c443a206e0/UserTemplate/110>. Acesso em: 25/1/2009. 
NORDSTRÖM, Kjell A.; VAHLNE, Jan-Erik. Psychic distance and the establishment of Swedish sales subsidiaries during the last 100 years. International trade: regional and global issues. In: . Is the globe shrinking? New York: St. Martin’s Press, 1994.

O BOTICÁRIO. Disponível em: <http://internet.boticario.com.br/portal /site/institucional/>. Acesso em: 25/1/2009.

OLIVEIRA Jr., Moacir de Miranda; FLEURY, Maria Tereza Leme (Org.). Gestão estratégica do conhecimento: integrando aprendizagem, conhecimento e competências. São Paulo: Atlas, 2004.

OVIATT, Benjamin M.; MCDOUGALL, Patricia Phillips. Toward a theory of international new ventures. Journal of International Business Studies. [S.1.], v. 36, p. 29-41, 2005. Disponível em:< http://proquest.umi.com/pqdweb?index=4\&did=101171953\&SrchMode= 2\&sid $=15 \&$ Fmt $=$ Vlnst $>$. Acesso em: 11/1/2009.

PALMER, Mark; QUINN, Barry. An exploratory framework for analysing international retail learning. The International Review of Retail, Distribution and Consumer. [S.1.], v. 15, n. 1, p. 27, Jan., 2005. Disponível em: <http://web.ebscohost.com/ehost/pdf $>$. Acesso em: $24 / 4 / 2007$.

PAULA, Sérgio Iunis C. de; PROENÇA, Eduardo de Rezende. O processo de internacionalização da Companhia Siderúrgica Nacional: conflito entre a teoria e um caso brasileiro. In: V WORKSHOP EM INTERNACIONALIZAÇÃO DE EMPRESAS. 2005. Disponível em: <www.coppead.ufrj.br/workshop/>. Acesso em: 21/1/2007.

PENROSE, Edith. Limits to the growth and size of firms. Papers and proceedings of the sixtyseventh annual meeting of the American Economic Association. The American Economic Review. [S.1.], v. 45, n. 2, p. 531-543, may, 1955. Disponível em: <http://www.jstor.org>. Acesso em: 10/2/2008.

. The theory of the growth of the firm. Oxford: Blackwell. 1959.

PRAHALAD, C. K.; DOZ, Yves L. Creating strategic capability: toward an "ideal DMNC organization". In: The multinational mission: balancing local demands and global vision. New York: Simon \& Schuster, 1987.

PORTER, Michael E. Competition in global industries: a conceptual framework. In: Competition in global industries. Boston: Harvard Business School Press, 1986.

PRUX, Bruna et al. A internacionalização da empresa Marcopolo: um estudo de caso. Jovens Pesquisadores, p. 8-23, 2005. Disponível em: <www.mackenzie.com.br>. Acesso em: $18 / 1 / 2007$. 
REMENYI, Dan. Researching information systems: data analysis methodology using content and correspondence analysis. Journal of Information Technology, v. 7, issue 2, p. 76-86, jun, 1992.Disponívelem: <http://web.ebscohost.com/ehost/pdf?vid=7\&hid=17\&sid=67f636195df5-49f0-b98a-064437200adf\%40sessionmgr107>. Acesso em: 5/3/2009.

RICUPERO, Rubens; BARRETO, Fernando Mello. A importância do investimento direto estrangeiro no exterior para o desenvolvimento socioeconômico do país. In: ALMEIDA, André (Org.). Internacionalização de empresas brasileiras: perspectivas e riscos. Rio de Janeiro: Elsevier, 2007.

RIFFE, Daniel et al. Analyzing media messages: using quantitative content analysis in research. New Jersey: Lawrence Erlbaum, 1998.

ROCHA, Angela da. Por que as empresas brasileiras não se internacionalizam? In:

(Org.). As novas fronteiras: a multinacionalização das empresas brasileiras. Coleção Estudos COPPEAD. Rio de Janeiro: Mauad, 2003.

RODRIGUES, Ivete et al. Internacionalização de empresas brasileiras do setor de construção civil: a experiência da Andrade Gutierrez. In: IX SEMEAD, 2006.

ROOT, Franklin R. Entry strategies for international markets. San Francisco: Jossey-Bass, 1998.

SAES, Maria Sylvia Macchione. Como evitar a queda da renda agrícola? Oficina PENSA. São Paulo, 2007.

SCHUMPETER, Joseph A. The theory of economic development: an inquiry into profits, capital, credit, interest, and the business cycle. Translated by Redvers Opie. 5th printin. New York: Oxford University Press, 1967.

SCOTT, W. Richard; CHRISTENSEN, Soren. The institutional construction of organizations. International and Longitudinal Studies. Thousand Oaks and London: Sage Publications. California, United States of America, 1995.

SELLING Perfumes in Paris. LatinFinance, p. 1. Coral Gables, Sep, 2005. Disponível em: $<$ http://proquest.umi.com/pqdweb>. Acesso em: 18/1/2007.

SHENKAR, Oded. Cultural distance revisited: towards a more rigorous conceptualization and measurement of cultural differences. Journal of International Business Studies. [S.1.], v. 32, n. 3, p. 519-535, 3rd quarter, 2001.

SHI, Yongjiang. Internationalisation and evolution of manufacturing systems: classic process models, new industrial issues, and academic challenges. Integrated Manufacturing Systems. [S.1.], v. 14, n. 4, p. 357-368, 2003. 
SILVA, Paulo Azzi da; ROCHA, Angela da. Perception of export barriers to Mercosur by Brazilian firms. International Marketing Review. MCB University Press, v. 18, n. 6, p. 589610, 2001. Disponível em: <http://proquest.umi.com/pqdweb>. Acesso em: 18/1/2007.

SIRMON, David G.; LANE, Peter J. A model of cultural differences and international alliance performance. Journal of International Business Studies. [S.1.], v. 35, p. 306-319, 2004. Disponível em: <http://proquest.umi.com/pqdweb>. Acesso em: 19/11/2007.

SPOLETO. Disponível em: <http://www.spoleto.com.br/index.php/historia>. Acesso em: 25/1/2009.

STERNQUIST, Brenda. International expansion of U.S. retailers. International Journal of Retail \& Distribution Management. Bradford, v. 25, n. 8, p. 262, 1997. Disponível em: $<$ http://proquest.umi.com/pqdweb $>$. Acesso em: 8/12/2007.

. International retailing. 2nd ed. USA: Fairchild, 2007.

TESFOM, Goitom; LUTZ, Clemens. A classification of export marketing problems of small and medium sized manufacturing firms in developing countries. International Journal of Emerging Markets. [S.1.]: Emerald, v. 1, n. 3, 2006. Disponível em: $<$ http://proquest.umi.com/pqdweb $>$. Acesso em: 18/1/2007.

TORDJMAN, André. European retailing: convergences, differences and perspectives. In: MCGOLDRICK, Peter; DAVIES, Gary (Ed.). International retailing: trends and strategies. London: Pitman Publishing, 1995.

VERNON, Raymond. International investment and international trade in the product cycle. The Quarterly Journal of Economics. [S.1.], v. 80, n. 2, p. 190-207, may, 1966. Disponível em: <http://www.jstor.org>. Acesso em: 10/2/2008.

The product cycle hypothesis in a new international environment. Oxford Bulletin of Economics and Statistics. Oxford, v. 41, n. 4, p. 255-267, 1979. Disponível em: $<$ http://web.ebscohost.com/ehost/pdf>. Acesso em: 10/2/2008.

Zahar, 1980.

Tempestade sobre as multinacionais. Tradução de Waltensir Dutra. Rio de Janeiro:

VIDA, Irena et al. Determinants of international retail involvement: the case of large U.S. retail chains. Journal of International Marketing. [S.1.], v. 8, n. 4, p. 37, 2000. Disponível em: <http://proquest.umi.com/pqdweb $>$. Acesso em: 15/4/2007.

WEBER, Robert Philip. Basic content analysis. 2nd ed. Series: Quantitative Applications in the Social Sciences. USA: Sage Publications, 1990. 
WELLER, Susan C.; ROMNEY, A. Kimball. Metric scaling: correspondence analysis. Newburry Park, California (USA): Sage Publications, 1990. Series: Quantitative Applications in the Social Sciences.

WHITELOCK, Jeryl. Viewpoint - Theories of internationalisation and their impact on market entry. International Marketing Review. MCB University Press, v. 19, n. 4, p. 342347, 2002. Disponível em: <http://proquest.umi.com/pqdweb>. Acesso em: 11/4/2007.

WILLIAMSON, Oliver E. The vertical integration of production: market failure considerations. The American Economic Review. [S.1.], v. 61, n. 2. Papers and Proceedings of the Eighty-Third Annual Meeting of the American Economic Association, p. 112-113, may, 1971. Disponível em: <http://www.jstor.org/stable/1816983>. Acesso em: 3/10/2008. 


\section{APÊNDICES}

APÊNDICE 1: ROTEIRO DE ENTREVISTA

APÊNDICE 2: TEORIAS - PROPOSIÇÕES

APÊNDICE 3: ENTREVISTA AREZZO (27/2/2008)

APÊNDICE 4: ENTREVISTA CARMEN STEFFENS (23/6/2008)

APENNDICE 5: ENTREVISTA CHILLI BEANS (11/2/2008)

APÊNDICE 6: ENTREVISTA LILICA RIPILICA (MARISOL) (28/3/2008)

APENNDICE 7: ENTREVISTA MORANA (8/2/2008)

APÊNDICE 8: ENTREVISTA MUNDO VERDE (25/3/2008)

APÊNDICE 9: ENTREVISTA NOBEL (22/4/2008)

APÊNDICE 10: ENTREVISTA O BOTICÁRIO (4/4/2008)

APENNDICE 11: ENTREVISTA SPOLETO (25/4/2008)

APENNDICE 12: ENTREVISTA VICTOR HUGO (30/1/2008)

APÊNDICE 13: ETAPAS DE INTERNACIONALIZAÇÃO DAS EMPRESAS PESQUISADAS 


\section{APÊNDICE 1: ROTEIRO DE ENTREVISTA}

\section{Bloco I - Caracterização do entrevistado}

\section{Qualificação do entrevistado:}

- $\quad$ Nome da empresa;

- $\quad$ Setor de atividade;

- $\quad$ Nome do entrevistado;

- Qual cargo ocupa na empresa?

- Qual o seu papel no processo de internacionalização da empresa?

- Há quanto tempo trabalha na empresa?

- $\quad$ Participa ou participou da atuação da empresa no exterior (como expatriado)?

- Durante quanto tempo?

\section{Bloco II - Processo de internacionalização da empresa}

\section{Processo de internacionalização:}

a) Por que sair - razão de se internacionalizar:

- Quem tomou a decisão de sair para outro país (único gestor ou colegiada)?

- Qual a função do tomador ou dos tomadores dessa decisão?

- Quando se deu a saída para o primeiro país?

- $\quad$ Por quê?

- Quais foram os motivos/as razões que impulsionaram a decisão de internacionalizar a operação da empresa?

b) Para onde ir (por que esse local):

- Qual foi o primeiro local internacional escolhido?

- $\quad$ Por que escolheu esse local (quais são os motivos dessa escolha)?

- $\quad$ Depois desse país, para onde a empresa foi (seqüência cronológica de deslocamento)?

- Qual foi o motivo que levou a empresa a se deslocar para cada um dos países (os motivos específicos relacionados a cada país)?

- $\quad$ Quais são os países onde a empresa pretende estabelecer operação (no futuro)?

- $\quad$ Por que escolheu esses locais (quais são os motivos dessas escolhas)?

- Como a empresa fez a escolha dos países para onde se deslocou?

- $\quad$ Por quê?

- $\quad$ O que levou em conta na hora de tomar essa decisão? 
- $\quad$ Por quê?

- Como a empresa analisa e avalia as opções para expansão internacional?

- $\quad$ O que leva em conta na hora da escolha de um novo local?

- Quais foram as oportunidades/facilidades identificadas?

- $\quad$ Quais foram as barreiras/dificuldades enfrentadas?

\section{c) Como entrar - modos de entrada escolhidos:}

- Qual foi o tipo de operação escolhido para entrada em cada país?

- Quais foram os motivos/as razões que levaram à escolha desse tipo de operação (barreiras/oportunidades)?

- $\quad$ Para os novos países onde pretende estabelecer operação, qual será o tipo de operação a ser adotado?

- Quais são os motivos/as razões que levam à escolha desse tipo de operação (barreiras/ oportunidades)?

\section{d) Como se adaptar ao novo local - o que foi feito para se adaptar:}

- Depois que a empresa entrou no novo país ela modificou a operação naquele local (contar o que aconteceu em cada país)?

- $\quad$ O que levou à mudança do tipo de operação em cada um dos países (por que essa modificação se deu)?

- Como está evoluindo o processo de internacionalização da sua empresa?

- Quais foram as etapas percorridas? 


\section{APÊNDICE 2: TEORIAS - PROPOSIÇÕES}

\section{PM - Teoria do Poder de Mercado}

PM 1 - A empresa reduz a competição em países estrangeiros por meio de conluios ou fusões. PM 2 - A empresa controla outras empresas em países estrangeiros para usar o acesso aos fatores de produção (vantagem única).

PM 3 - A empresa controla outras empresas em países estrangeiros para dominar formas de produção mais eficientes (vantagem única).

PM 4 - A empresa controla outras empresas em países estrangeiros para ter acesso a um melhor sistema de distribuição (vantagem única).

PM 5 - A empresa controla outras empresas em países estrangeiros para ter acesso a produto diferenciado (vantagem única).

PM 6 - A firma produz no exterior em função das imperfeições de mercado.

PM 7 - A combinação de recursos gerenciais da firma cria novos mercados.

PM 8 - Os recursos gerenciais acumulados durante o processo de inovação e adaptação ao novo mercado contribuem para a construção de vantagem no novo mercado.

\section{CP - Teoria do Ciclo do Produto}

CP 1 - A empresa modifica seu modo de atuação em países estrangeiros em função do ciclo de vida de um produto.

CP 2 - A fase de introdução do produto se dá em países mais desenvolvidos.

CP 3 - A fase de introdução do produto apresenta constante mudança nas tecnologias.

CP 4 - A fase de introdução do produto é marcada pelo desenvolvimento de mercado.

CP 5 - A fase de introdução do produto apresenta grandes investimentos destinados à pesquisa e desenvolvimento.

CP 6 - A fase de crescimento do produto espalha a produção pelos países desenvolvidos.

CP 7 - A fase de crescimento do produto é marcada pela demanda estrangeira.

CP 8 - A fase de crescimento do produto inicia a difusão da tecnologia.

CP 9 - A fase de crescimento do produto é marcada pela produção em larga escala.

CP 10 - A fase de crescimento do produto é marcada pelo enfraquecimento das barreiras de entrada.

CP 11 - A fase de maturação do produto é marcada por produção e tecnologia mais padronizadas.

CP 12 - A fase de maturação do produto não apresenta inovações. 
CP 13 - A fase de maturação do produto requer pouca qualificação de mão-de-obra.

CP 14 - A fase de maturação do produto transfere a produção para países que ofereçam custos mais baixos.

\section{IN - Teoria de Internalização}

IN 1 - A escolha dos locais se dá pelo critério daqueles que oferecem menores custos para suas atividades.

IN 2 - A firma integra a produção quando os custos de produção no mercado forem grandes.

IN 3 - A firma integra a produção quando a especificidade dos ativos for grande.

IN 4 - A firma integra a produção para vencer barreiras de entrada.

IN 5 - A firma integra a produção quando há incertezas de mercado.

\section{PE - Paradigma Eclético}

PE 1 - A firma possui vantagem específica de propriedade de marcas.

PE 2 - A firma possui vantagem específica de propriedade da capacitação tecnológica.

PE 3 - A firma possui vantagem específica de propriedade da qualificação da mão-de-obra.

PE 4 - A firma possui vantagem específica de propriedade de patentes.

PE 5 - A firma possui vantagem específica de localização dos recursos naturais.

PE 6 - A firma possui vantagem específica de localização de mão-de-obra.

PE 7 - A firma possui vantagem específica de localização de infra-estrutura.

PE 8 - A firma possui vantagem específica de localização de mercado.

PE 9 - A firma possui vantagem específica de internalização (capacidade e desejo da empresa multinacional de transferir ativos através das fronteiras nacionais dentro de sua própria hierarquia, ao invés de se valer do mercado internacional).

\section{EU - Escola de Uppsala}

EU 1 - A firma internacionaliza por meio de um processo gradual.

EU 2 - A firma adquire gradativamente conhecimento do local para o qual pretende se deslocar (aprendizagem).

EU 3 - A cultura em determinado local interfere no processo de expansão da empresa.

EU 4 - O idioma em determinado local interfere no processo de expansão da empresa.

EU 5 - A educação em determinado local interfere no processo de expansão da empresa.

EU 6 - As práticas de negócio em determinado local interferem no processo de expansão da empresa. 
EU 7 - O desenvolvimento do setor em determinado local interfere no processo de expansão da empresa.

EU 8 - O relacionamento com os clientes em determinado local interfere no processo de expansão da empresa.

EU 9 - O relacionamento com os fornecedores em determinado local interfere no processo de expansão da empresa.

EU 10 - O relacionamento com os distribuidores em determinado local interfere no processo de expansão da empresa.

EU 11 - O relacionamento com as agências reguladoras em determinado local interfere no processo de expansão da empresa.

EU 12 - O relacionamento com os concorrentes em determinado local interfere no processo de expansão da empresa.

\section{EN - Escola Nórdica de Negócios Internacionais}

EN 1 - O empreendedor (indivíduo) é o responsável pelo desenvolvimento de novos mercados.

EN 2 - O indivíduo emprega sua rede de relacionamentos em novos mercados.

EN 3 - O empreendedor técnico volta-se para produção e processos.

EN 4 - O empreendedor de marketing volta-se para clientes e mercados.

EN 5 - O empreendedor estrutural volta-se para a estrutura organizacional.

\section{CC - Teoria sobre Competição e Competitividade Global}

CC 1 - A empresa determina sua estratégia em função da excelência operacional.

CC 2 - A empresa determina sua estratégia pela análise de produtos.

CC 3 - A empresa define sua estratégia pela análise de concorrentes.

CC 4 - A empresa define sua estratégia pela análise de consumidores.

CC 5 - A empresa determina sua estratégia pela análise de oportunidades.

CC 6 - A empresa define seu posicionamento estratégico para atuar em um novo local.

\section{EO - Abordagem sobre Gestão Estratégica de Operações}

EO 1 - A firma escolhe a estrutura organizacional para atuar no mercado em função das características desse mercado.

EO 2 - A firma escolhe a estrutura organizacional para atuar no mercado em função de suas características internas. 
EO 3 - A firma escolhe a estrutura organizacional para atuar no mercado em função de sua habilidade de gerenciar além-fronteiras.

EO 4 - A firma escolhe a estrutura organizacional para atuar no mercado em função de sua rede de relacionamentos internacionais.

EO 5 - A firma escolhe a estrutura organizacional para atuar no mercado em função do nível de dispersão geográfica de atuação.

EO 6 - A firma escolhe a estrutura organizacional para atuar no mercado em função da concorrência.

\section{GC - Abordagem sobre Gestão de Competências}

GC 1 - A empresa tem a capacidade de aprender com o ambiente.

GC 2 - A empresa tem a capacidade de desenvolver estratégias.

GC 3 - A empresa tem a capacidade de disponibilizar as funções de operação.

GC 4 - A empresa tem a capacidade de disponibilizar a função de desenvolvimento de produto.

GC 5 - A empresa tem a capacidade de disponibilizar a função de comercialização.

GC 6 - A empresa tem a capacidade de gerenciar inovação.

GC 7 - A empresa tem a capacidade de gerenciar pessoas no exterior.

\section{CO - Abordagem sobre Gestão do Conhecimento}

CO 1 - O conhecimento resulta do compartilhamento de experiências entre os membros da organização.

CO 2 - O conhecimento resulta do compartilhamento da aprendizagem entre os membros da organização.

\section{AI - Abordagem Intercultural}

AI 1 - A cultura de um país ou região interfere na cultura da organização.

AI 2 - Os valores de um grupo influenciam a gestão da empresa.

AI 3 - As crenças de um grupo influenciam a gestão da empresa.

AI 4 - As normas de um grupo influenciam a gestão da empresa.

AI 5 - Os padrões de comportamento de um grupo influenciam a gestão da empresa. 


\section{APÊNDICE 3: ENTREVISTA AREZZO (27/2/2008)}

\section{Bloco I - Caracterização do entrevistado}

\section{Qualificação do entrevistado:}

Nome da empresa:

- $\quad$ Arezzo S.A.

Setor de atividade:

- Calçados, artigos de couro e acessórios. Fabricante de calçados, varejo e indústria.

Nome do entrevistado:

- $\quad$ Mário Goldberg

\section{Cargo que ocupa na empresa:}

- Diretor executivo responsável pela área internacional, Arezzo Internacional.

\section{Seu papel no processo de internacionalização da empresa:}

- $\quad$ Eu sou o diretor que está responsável por fazer a gestão da marca, e a gestão dessa expansão lá fora. Então para isso tem todos os critérios, e assim, as discussões e aprovações.

\section{Bloco II - Processo de internacionalização da empresa}

\section{Processo de internacionalização - Tematização:}

a) Por que sair - razão de se internacionalizar:

- contingência do mundo (CC 5)

- $\quad$ percebe que tem demanda, mercado, unidade de negócios, traders, material para o mercado externo (CC 5)

- $\quad$ se estrutura melhor (CC 6)

- $\quad$ criar uma marca global, (CC 6)

- $\quad$ ser competitivo, (CC 6)

- $\quad$ grife internacional (CC 6)

- $\quad$ estar na Europa (CC 6)

- $\quad$ abertura de mercado do plano Collor (CC 5)

- $\quad$ A qualidade e criatividade do design brasileiro (PE 3)

- $\quad$ qualidade para o mercado interno (PE 8)

- estrangeiros que detectaram uma boa oportunidade pelo preço, competitividade, produto, qualidade (CC 5)

- $\quad$ brasileiros que foram morar fora, (CC 5) 


\section{b) Para onde ir (por que esse local):}

- países com desenvolvimento econômico grande (CC 5)

- $\quad$ o que vai gerar de receita, despesa, o investimento (CC 5)

- $\quad$ a proximidade cultural e geográfica. (EU 3)

- $\quad$ facilidade do idioma (EU 4)

- $\quad$ emergentes (CC 6)

- $\quad$ África do Sul em 2010 você vai ter a Copa do Mundo, (CC 5)

- $\quad$ baixa concorrência... (PM 7; CC 3; CC 5)

- $\quad$ Mercosul. (EU 2; CC 5)

- Hugo Chávez protegeu a indústria, abrindo um relacionamento com o Brasil. (CC 5)

- $\quad$ a facilidade do idioma (EU 4)

- $\quad$ A economia crescente (CC 5)

- $\quad$ barreiras tarifárias. (CC 5)

- $\quad$ embargos políticos, (CC 5)

- $\quad$ questão cultural, (CC 5; EU 3)

- faltam acordos. (CC 5)

- $\quad$ a China são 22 mil quilômetros (CC 5)

- $\quad$ Europa é o berço da moda (CC 6)

- $\quad$ novo parceiro $\{$ Arábia Saudita (CC 5)

- $\quad$ abordar os países onde a gente não está, (CC 6)

- $\quad$ nos que a gente está, dar uma expansão (CC6)

- $\quad\{$ China $\}$ abrindo 12 lojas, até 2012, 207 lojas. (CC6)

- China e América Latina são os objetivos dos focos da expansão, (CC6)

- $\quad$ definimos um outro grupo os países ibéricos e os países da África (CC6)

c) Como entrar - modos de entrada escolhidos:

- $\quad$ a gente exportou para os Estados Unidos e para vários países (EU 1)

- $\quad$ Feiras (CC 6; EU 1)

- unidade de negócio Arezzo Internacional tem todos os critérios, as discussões e aprovações... (EO 2; GC 2)

- existe uma discussão muito grande no comitê executivo, validação do potencial mercado (GC 2; CO 1; CO 2; CC 5; CC 6)

- $\quad$ não é uma forma planejada, é uma forma muito mais de oportunidade. (CC 5) 
- $\quad$ um empreendedor que tem cinco lojas na Colômbia e Venezuela, vem aqui e compra para as lojas dele (CC 5)

- $\quad$ forma prospectiva, fomos buscar essas pessoas. (CC 6)

- $\quad$ trabalhar com outros formatos de distribuição, franquias. (EO 2; EU 1)

- $\quad$ mapeia, \{estratégia para entrar no país\} (CC 6)

- $\quad$ estuda, \{estratégia para entrar no país\} (CC 6)

- $\quad$ avalia, \{estratégia para entrar no país\} (CC 6)

- $\quad$ escolhe a localização. \{estratégia para entrar no país\} (CC 6)

- $\quad$ definimos o plano de expansão, \{estratégia para entrar no país \} (CC 6)

- $\quad$ o parceiro local faz o movimento \{estratégia para entrar no país\} (CC 6)

- $\quad$ a gente faz duas viagens por ano, dar o apoio (GC 3)

- $\quad$ Avaliar resultados (GC 3)

- $\quad$ traçar planos de correção de rota. (CC 6; EU 2)

- investidor que tenha o perfil de operação que nós buscamos e a capacidade de investimento ( $\mathrm{CC} 6)$

- $\quad$ mais de 50 países com distribuição de produtos (CC 6)

- $\quad$ não tem loja própria no exterior (CC 6)

- $\quad$ dez anos \{franquias\} (CC 6)

- $\quad$ fazer dentro do planejamento, de negociação \{China $\}$ (CC 6)

- $\quad$ um ano de estudo de mercado, montagem \{China\} (CC 6)

- $\quad$ discussão de business plan, de formatação e de contracts, de contratos \{China\} (CC 6)

\section{d) Como se adaptar ao novo local - o que foi feito para se adaptar:}

- O caminho de entrada de distribuição nos possibilitou conhecer, identificar o potencial do mercado, sem incorrer num modelo de varejo. (EU 8)

- $\quad$ Europa e a questão cultural e o deslocamento, o hemisfério trocado (CC 5; EU 2)

- $\quad$ existem os devidos ajustes e adaptações às situações culturais. (EU 3)

- $\quad$ ajustes com relação à numeração (EU 8)

- $\quad$ um tipo de produto não funciona. (CC 5; EU 8)

- $\quad$ um planejamento mais estruturado (CC 6)

- $\quad$ treinamento, retreinamento, (GC 3; CO 1; CO 2)

- $\quad$ a forma de arrumar, mostrar, displayar o produto, (GC 3)

- $\quad$ forma de vender, (GC 3)

- $\quad$ a comunicação do ponto de venda. (GC 3) 
- $\quad$ aprovação e suporte \{da linha de campanha e divulgação da marca\} (GC 3)

- $\quad$ vêm duas a três vezes por ano no Brasil, participar lançamentos. (GC 3)

- $\quad$ estamos expatriando uma coordenadora por seis meses para cuidar da implementação.

$(\mathrm{CO} 1)$

- $\quad$ essas avaliações \{dos países para onde ir\} hoje são diferentes. (EU 2)

- $\quad$ incluir o individual e coorporativo. (CO 1; $\mathrm{CO} 2)$

- $\quad$ estabelecemos como a macroestratégia da empresa a internacionalização da marca. (CC 6) 


\section{APÊNDICE 4: ENTREVISTA CARMEN STEFFENS (23/6/2008)}

\section{Bloco I - Caracterização do entrevistado}

\section{Qualificação do entrevistado:}

Nome da empresa:

- $\quad$ Carmen Steffens

Setor de atividade:

- Calçados, segmento de moda

\section{Nome do entrevistado:}

- Gabriel Spaniol

\section{Cargo que ocupa na empresa:}

- Diretor internacional de expansão

\section{Seu papel no processo de internacionalização da empresa:}

- a gente começou a estudar o mercado internacional a fím de estar vendo quais são as oportunidades que ele oferecia para a Carmen,

\section{Bloco II - Processo de internacionalização da empresa}

\section{Processo de internacionalização - Tematização:}

a) Por que sair - razão de se internacionalizar:

- $\quad$ clientes vinham ao Brasil consumiam o nosso produto (CC 4)

- $\quad$ eu e a diretoria da empresa (CC 6; EN 1)

- $\quad$ franqueada teve que nos convencer de que seria um negócio excelente (CC 5)

- $\quad$ oportunidade (CC 5)

- $\quad$ estudar o mercado internacional (CC 3; EU 3)

- $\quad$ o nosso produto é bem diferenciado (PE 1)

- $\quad$ temos produtos da marca em seriados (CC 6)

- $\quad$ calçamos algumas celebridades no tapete vermelho (CC 6)

- $\quad$ internacionalização tem sido muito interessante para a imagem da marca (CC 5)

- marca internacional acaba adicionando ainda mais valor para a marca aqui no mercado brasileiro (CC 5)

- $\quad$ a gente diversifica também os mercados (PM 7; CC 6)

- a primeira loja foi reativa (CC 5)

- $\quad$ recebendo contato (CC 5) 
- mas as outras resultaram de trabalho, a empresa foi traçando estratégias e não aguardando que as pessoas descobrissem a Carmen (CC 6)

\section{b) Para onde ir (por que esse local):}

- $\quad$ franqueada conheceu a marca no Brasil (CC 5)

- $\quad\{$ EUA $\}$ encontraram a Carmen (CC 5)

- $\quad$ Portugal. Pela facilidade, principalmente pela facilidade da língua (EU 4)

- $\quad$ existem questões culturais, existe a questão da proximidade do México com os Estados Unidos (EU 3)

- $\quad$ estudo do local (EU 2)

- $\quad$ competidores (CC 3$)$

- $\quad$ nossa política de preço (CC 2)

- $\quad$ o clima favorável para o nosso produto (CC 5)

- $\quad$ entrar primeiro em Portugal e Espanha, fortalecer a marca, depois dar um passo maior dentro da Europa (CC 6)

- $\quad$ Em Punta del Este, tivemos um sucesso com clientes da Argentina (CC3)

- $\quad$ muitas pessoas de Portugal conheciam a marca (PE 1)

- $\quad$ estilo brasileiro (PE 1)

- $\quad$ Buenos Aires \{projeto de expansão\} (CC 6)

- $\quad$ abrir duas lojas na Espanha (CC 6)

- $\quad$ Las Vegas \{projeto de expansão\} (CC 6)

- a gente vem buscando contatos na Grécia (CC 6)

- $\quad$ até 2020 ter pelo menos 100 lojas fora do Brasil (CC 6)

- $\quad$ expandir nos EUA (CC 6)

- $\quad$ um contrato nos Estados Unidos para abrir 60 lojas em dez anos (CC 6)

- $\quad$ ampliar nos mercados onde a gente já está (CC 6)

- televisão na Austrália vai fazer uma matéria sobre a brasileira que mudou para a Austrália só para abrir uma loja. O canal vai mostrar a loja e vai fazer uma matéria sobre ela (CC 5)

\section{c) Como entrar - modos de entrada escolhidos:}

- $\quad$ exportar através de feiras (EU $1 ;$ CC 6)

- $\quad$ hoje a franquia (CC 6; EU 1)

- $\quad$ a prioridade é loja (CC 6) 
- $\quad$ Estados Unidos é franquia, não máster (CC 6)

- $\quad$ vi muita oportunidade na Austrália (EN 1; CC 5)

- $\quad$ começamos a buscar parceiros, um amigo me indicou um consultor (CC 6; EN 2)

- $\quad$ franquia (EU 1; CC 6)

- $\quad$ iniciando um estudo (EU 2)

- $\quad$ marketing forte (CC 6)

- $\quad$ Portugal a gente dividiu o país em três (CC 6)

- $\quad$ não estamos trabalhando com máster (CC 6)

- $\quad$ a gente estudou o mercado americano, participamos de feiras (EU 1; EU 2)

- $\quad$ para entrar forte $\{E U A\}$ teríamos que primeiro entrar forte na Flórida e Califórnia (EU

2; CC 6)

- $\quad$ antes de montar um bom business plan sobre o país (CC 6)

- $\quad$ avaliar o potencial dos franqueados (CC 6)

- para um máster tem de ter o conhecimento que temos de gestão, teria que ser do ramo (CO 1)

- $\quad$ O papel dos escritórios de Portugal e Los Angeles é ser a visão da Carmen no mercado (EU 2; CC 3; CC 4; GC 3; IN 5)

- $\quad$ sempre, após a primeira ou a segunda loja, a gente já começa a buscar colocar um escritório da marca no país (EU 1; CC 6; EO 2)

- $\quad$ a gente tem a nossa forma de avaliar pessoas e buscá-las no mercado (GC 3)

- toda a parte de treinamento inicial com a nossa equipe do Brasil que também vai ao exterior para fazer esse trabalho (GC 3; CO 1; CO 2)

- $\quad$ auxiliar o nosso investidor a tomar as decisões (CO 1; CO 2)

- $\quad$ apresentando boas taxas de crescimento (CC 6)

- $\quad$ não tem \{pontos próprios\} (CC 6)

\section{d) Como se adaptar ao novo local - o que foi feito para se adaptar:}

- a gente sempre está analisando as necessidades dos mercados que a gente decide entrar (CC 3; CC 4)

- a gente consegue adaptar o nosso produto, dentro dessa gama de opções \{diferentes estilos, cores e matéria-prima\} que temos (CC 2; GC 4)

- $\quad$ existem diferenças culturais, mas a gente tem aplicado muitas coisas que são do nosso sistema em outros países com grande êxito (EU 3)

- $\quad$ temos experiência do que funciona, dos mercados (EU 2) 
- $\quad$ Hoje temos uma metodologia (EU 2; GC 3)

- Temos umas ferramentas de onde eu posso enviar vídeos da empresa, imagens, franchising via e-mail (GC 3)

- $\quad$ facilidade a se adaptar a inúmeros mercados (EU 2; GC 1)

- $\quad$ temos brasileiros constantemente viajando (CO 1; $\mathrm{CO} 2)$

- $\quad$ temos seis funcionários no total, quatro em Portugal e dois nos Estados Unidos (CG 3)

- $\quad$ A equipe de loja sempre local (EU 2; EO 1; EO 2)

- $\quad$ A Argentina não teve mudanças na operação de lojas (EO 1; EO 2) 


\section{APÊNDICE 5: ENTREVISTA CHILLI BEANS (11/2/2008)}

\section{Bloco I - Caracterização do entrevistado}

\section{Qualificação do entrevistado:}

Nome da empresa:

- Chilli Beans. Fortuna Conection e Franquias Ltda

Setor de atividade:

- $\quad$ Empresa de acessórios de moda

\section{Nome do entrevistado:}

- $\quad$ Mário Ponci Neto

\section{Cargo que ocupa na empresa:}

- $\quad$ Diretor de expansão e marketing

Seu papel no processo de internacionalização da empresa:

- $\quad$ todo o planejamento, vê que momento a empresa está, e o que ela deve fazer, e por quê. Monto a estratégia, faço um plano de ação e vou atrás dos objetivos

\section{Bloco II - Processo de internacionalização da empresa}

\section{Processo de internacionalização - Tematização:}

a) Por que sair - razão de se internacionalizar:

- $\quad$ começaram a aparecer interessados (CC 5)

- Nesse momento \{quando foi procurado\}, acendeu uma luzinha, é uma empresa que pode ser internacionalizada (CC 5)

- Quem tomou decisão de sair foi o interessado, veio com uma proposta de colocar em Beiton, depois Inglaterra (CC 5)

- $\quad$ Eu e o Caito ou nós sentamos, eu e o Caito, e a Denise (CO 1; CO 2)

b) Para onde ir (por que esse local):

- $\quad$ uma marca que é muita sintonia com a Califórnia, Tent Beach (PE 1)

- $\quad$ O cara preenche pelo site um questionário, para ver quais os pontos que temos interesse e o que ela tem de pessoa interessada, faz a primeira entrevista, se tem o perfil, faz todo um processo, só depois senta com a gente (CC 6)

- $\quad$ Estados Unidos é um mercado com potencial enorme, agressivos (CC 3) 
- $\quad$ apareceu Rui Nunes, português, de negócios de varejo querendo levar para Portugal (CC

5)

- $\quad$ Portugal, foi que começou a disseminar para dentro da Europa. (EU 2; PE 8)

- $\quad$ nos Estados Unidos o nosso negócio, o atendimento seria um diferencial, (CC 1; CC3)

- $\quad$ as pessoas formadoras de opinião, estavam começando a usar Chilli Beans. (CC 6)

- $\quad$ sai na Rolling Stones há uns três anos, o Foo Fighters numa foto na Austrália, todos de óculos Chilli Beans. (CC 6)

- $\quad$ um ponto estratégico foi o aeroporto \{Portugal\} (PE 8)

- temos essa loja $\{$ Melrose\}, agora já sabemos, estamos preparados, pra esse ano agora, vamos entrar com o primeiro shopping, já erramos o que podíamos errar (EU 2; CC 6)

- $\quad$ levar pra Alemanha, (CC 6)

- $\quad$ Dubai, \{projeto de expansão\} (CC 6)

- $\quad$ Oriente Médio, 15 pontos em 2008 \{projeto de expansão\} (CC 6)

- $\quad$ entrar em mais dez países \{projeto de expansão\} (CC 6)

- ficar com uns 30 pontos nos próximos três, quatro anos. Fazer uma store-in-store \{projeto de expansão\} (CC 6)

- $\quad$ algumas lojas nos aeroportos, também com minilojas, que é um projeto que a gente não tinha \{projeto de expansão\} (CC 6)

- $\quad$ Panamá \{projeto de expansão\} (CC 6)

- $\quad$ Colômbia \{projeto de expansão\} (CC 6)

- $\quad$ Venezuela \{projeto de expansão\} (CC 6)

- $\quad$ Um franqueado nosso brasileiro, vai abrir no Chile \{projeto de expansão\} (CC 6)

- comunidade européia, são 27 países com potencial de 248 pontos, já estudei os pontos, sei a estratégia, tenho que identificar se vai ser uma pessoa por país, um grupo \{projeto de expansão\} (CC 6)

\section{c) Como entrar - modos de entrada escolhidos:}

- $\quad$ pesquisa de costume e hábito (EU 2; EU 3)

- $\quad$ nosso negócio é qualitativo (CC 6)

- $\quad$ Por quiosque, depois a idéia é ir pra loja (EU 1)

- $\quad$ Nós começamos a desenhar a estratégia de Portugal, um público mais trendy, um lugar legal de entrar, Europa o espaço é muito escasso e muito caro (CC 4; CC 6)

- $\quad$ não foi num grupo trendy, pra gente conhecer como é uma operação fora, sem impactar nosso público primeiro, nosso target (EU 8; CC 4; CC 6) 
- $\quad$ andamos por Los Angeles na Melrose. Primeiro Melrose, pra o público trendy assim ao extremo, só $16 \%$ das pessoas que transitam na Melrose são americanos, a gente podia errar, o que desse pra errar. Se entrássemos direto no shopping, e nós errássemos, a nossa marca tava morta nos Estados Unidos (CC 6; EU 2; EU 8)

- E outra coisa, se eles \{EUA\} gostarem do teu conceito da tua marca, eles montam alguma coisa igualzinho e explodem em 2 mil lojas (CC 5)

- na Melrose, fomos bater papo com os vendedores, fizemos essa pesquisa, o que o cliente esperava, o que gostava, preço dos óculos (EU 2)

- $\quad$ A loja de rua $\{$ Melrose $\}$ (EU 2)

- $\quad$ identificamos que pra entrar no Estados Unidos, naquele momento, o melhor é entrar na Califórnia. (PE 1; CC 5; CC 6)

- apareceram alguns portugueses, eram mais investidores, tinham dinheiro na mão, conhecimento de varejo, mas não tinham o DNA na mão. (CC 5)

- Nosso negócio é operar, somos varejistas, é trabalhar a marca, o cliente, o produto, o conceito. (CC 6)

- $\quad$ negociando o contrato com o Rui \{franqueado português\}, eu queria saber primeiro até onde ele tinha garra, queria ter a marca, iria brigar por isso, fui bem devagar. (CC 5; EU 10)

- $\quad$ é uma franquia que tem direito a licenciar \{Portugal\}. Ele pode ter sócio desde que ele participe com 51\%. Ele é que me interessa comandar a operação. (CC 6)

- cresce com vários quiosques, dá um impacto no mercado, pra eles começarem a perceber que você tem vários pontos de venda. (CC 6)

- $\quad$ ele experimentar o produto e falar: "Gostei do produto" e vai falar pra outro (CC 6)

- $\quad$ fizemos uns kits e um vale-óculos. O importante era levar o artista pra comprar na nossa loja. Saber quem é, perceber o gosto da pessoa em relação ao produto. (CC 6)

- $\quad$ os artistas começaram a aparecer na nossa loja. (CC 5)

- $\quad$ começaram a gostar e voltar pra comprar (CC 5)

- $\quad$ vai entrar, sentir o cheiro e falar: "Tá na Chilli Beans". (CC 6)

- $\quad$ É pelo atendimento, pelo sorriso do cara \{vendedor\} (PE 3; CC 6)

- $\quad$ nos associamos ao Internacional Shopping Center, que tem 45 mil shoppings centers associados no Estados Unidos, já começamos a fazer o movimento, pra poder entrar e quando entrar agressivo. (CC 6)

- Vender a franquia prum grupo que tenha potencial de expandir agressivamente no Estados Unidos (CC 6) 


\section{d) Como se adaptar ao novo local - o que foi feito para se adaptar:}

- no Brasil não temos normas, regras atrás, acho que montar um departamento de importação, antes era só de importação, um departamento de exportação, exportar o produto. Começar a trazer pessoas de exportação pra dentro, um departamento aqui pra fazer o quê? Pra quando tem importação e exportação. (EO 2; CO 1)

- não tínhamos um critério de logística, abastecimento, todo o know-how, (EU 2)

- $\quad$ Estamos acostumados com shopping, e quiosque \{Melrose loja na rua\} (EU 2)

- $\quad$ se der certo $\{$ Melrose\}, depois vamos pra o shopping. Temos que nos preparar pra ir, tem que ir com um grupo por trás, é muita grana. (CC 6)

- $\quad$ já temos um outro formato, sabemos os caminhos. (EU 2)

- departamento de marketing, fica no Brasil. Como vamos fazer, criar um conceito, em Portugal (CC 6; EO 2; GC 2)

- $\quad$ ser adaptado, para que o mercado entenda a marca, (EU 2; CC 6)

- $\quad$ Portugal $\}$ tínhamos um formato, ele começa a ser desenhado conforme o varejo vai te dizendo; se você vai vendo a resposta. (EU 2)

- $\quad$ problema grave de mão-de-obra. (AI 5)

- $\quad$ brasileiro ele tem um perfil, o europeu tem outro, (AI 1)

- $\quad$ Lá, a vendedora não entendia, (AI 5)

- $\quad$ Pegamos o nosso melhor gerente do Brasil, e exportamos pra Portugal. (CO 1)

- $\quad$ um supervisor brasileiro que de dois em dois meses tá em Portugal. (GC 3; CO 1; CO 2)

- Começamos a trabalhar dois anos em Portugal entendendo todos os problemas, é imposto de entrada do produto (EU 2; EU 11)

- $\quad$ sempre abrir ponto fora, temos que levar o pessoal nosso daqui. (GC 3; CO 1; CO 2)

- $\quad$ o Rui \{Portugal\} trouxe pra trabalhar com ele a Marta, que é de marketing, trabalha muito ligada ao nosso marketing aqui (CO 1)

- um dos pontos-chave é, ter um brasileiro no comando de vendas e uma pessoa de marketing local, ligada ao nosso marketing daqui, e uma assessoria de imprensa abastecida pela nossa assessoria de imprensa daqui (GC 3; CO 1; EO 2)

- tivemos muitas dificuldades, com conceito e tudo o mais, isso foi ótimo pra gente, a empresa cresceu muito. Essas dificuldades obrigaram a empresa a se profissionalizar de uma maneira brutal, começar a enxergar além dos limites do Brasil. (EU 2)

- temos a loja e os escritórios das fábricas da China no Estados Unidos, o óculos vai primeiro pra o Estados Unidos, (EO 2)

- $\quad$ vamos abastecer o mundo pelo Estados Unidos. (EO 2) 


\section{APÊNDICE 6: ENTREVISTA LILICA RIPILICA (MARISOL) (28/3/2008)}

\section{Bloco I - Caracterização do entrevistado}

\section{Qualificação do entrevistado:}

Nome da empresa:

- Marisol \{Lilica Ripilica\}

Setor de atividade:

- Moda feminina para crianças até 11 anos

\section{Nome do entrevistado:}

- $\quad$ Robson Amorim

\section{Cargo que ocupa na empresa:}

- Há 12 dirigindo a área comercial no mercado interno e externo

\section{Seu papel no processo de internacionalização da empresa:}

- $\quad$ no dia 10 de setembro de 2001, eu fui fazer a primeira feira internacional da Marisol, foi em Paris. Fui tentar vender para europeu, e na verdade apareceu um libanês que ficou apaixonado pelo produto e quis abrir lojas. (...)nós fechamos um primeiro negócio, que ele fez uma compra de 1 milhão de dólares e abriu instantaneamente quatro lojas no Líbano

- $\quad$ eu trabalho na Marisol há 19 anos, e há 12 dirigindo a área comercial no mercado interno e externo. $\{\ldots\}$ eu fiquei durante três anos exclusivamente no mercado externo para desenvolver esse trabalho.

\section{Bloco II - Processo de internacionalização da empresa 1. Processo de internacionalização - Tematização:}

\section{a) Por que sair - razão de se internacionalizar:}

- Cinco anos atrás decidimos inicializar um processo de internacionalização, temos algum portfolio de marcas (PE 1; CC 6)

- Pessoas do exterior que vinham para cá, entravam nas nossas lojas, gostavam, queriam saber como fazer para levar para fora e coisas desse tipo. (CC 5)

- Há uns quatro anos atrás, nós decidimos... Cinco anos atrás, decidimos inicializar um processo de internacionalização e... decidimos que a marca Lilica Ripilica, seria a marca com potencial para ser internacionalizada (CC 6)

- $\quad$ Foi aí que a gente tomou essa decisão (CC 6)

- $\quad$ Uma marca globalizada se distancia dos seus concorrentes. (CC 3; CC 6) 


\section{b) Para onde ir (por que esse local):}

- foi uma situação do acaso, surgiu uma oportunidade e nós começamos do Oriente Médio (CC 5)

- $\quad$ 2001, em uma feira em Paris, apareceu um libanês e abriu quatro lojas no Líbano (CC

5)

- $\quad$ A partir dali, nós começamos a definir aonde queremos ir. (CC 6)

- $\quad$ estarmos próximos para testar o mercado \{América do Sul\}. (EU 2; CC 6)

- decidimos estrategicamente ir para a Europa, fazer um trabalho super planejado a partir do mercado europeu, para fazer um buypass, queremos entrar no mercado americano a partir da Europa (CC 6)

- $\quad$ Itália é um grande produtor, criador de produto confeccionado (CC 2)

- $\quad$ tem uma relação com a criança muito forte \{Itália\} (CC 2)

- gosto de vestir mais próximo do brasileiro \{Península Ibérica, México\} (EU 8)

- $\quad$ a Lilica Ripilica vendia há tempo em Portugal, no canal multimarca (EU 1)

- $\quad$ o mercado mexicano tem um poder de consumo muito forte (CC 4)

- a Colômbia, por exemplo, ela tem o ano inteiro uma condição climática que é flat, de dia faz calor e de noite faz frio (EU 2)

- $\quad$ o Brasil é péssimo em acordos bilaterais, (CC 5)

- O americano, em respeito à roupa brasileira, ainda nos enxerga como eles chamam de mochileiro, como é o mercado mexicano, que é um produtor de têxteis para eles. Eles não acreditam que nós temos marcas, ou coisas desse tipo ainda (CC 3; CC 2; CC 5)

- não estamos na Argentina, porque quando começamos esse processo lá atrás, era um momento perigoso na economia da Argentina (CC 5)

- Sofremos uma concorrência fortíssima da Espanha (CC 5)

- $\quad$ uma loja na cidade do Porto, no Norte Shopping, que é o melhor shopping center de Portugal (PE 8)

- $\quad$ Panamá. \{projeto de expansão\} (CC 6)

- $\quad$ vias caribenhas \{projeto de expansão\} (CC 6)

- $\quad$ Portugal abrir mais duas lojas \{projeto de expansão\} (CC 6)

- $\quad$ Peru, uma terceira. \{projeto de expansão\} (CC 6)

c) Como entrar - modos de entrada escolhidos:

- $\quad$ Exportávamos de maneira passiva. (CC 6; EU 1)

- $\quad$ Sete anos com exportação (EU 1; EO 2) 
- participando de feiras do Brasil, vem um ou outro comprador internacional e a gente vendia, a gente exportava simplesmente (CC 6; EU 1)

- $\quad$ Porque era a marca que estava mais pronta para o mercado externo, todas as coleções que vendemos para o mercado interno, pesquisamos a moda no exterior (CC 2; CC 6)

- $\quad$ A marca pediu um portfolio de produto maior. (CC 2)

- $\quad\{$ Líbano\} ele não é um máster, é um distribuidor que tem algumas pessoas lá, operação de máster-franquia, não está em seu contrato. (EO 4)

- $\quad$ Porque cada país tem a sua peculiaridade (EU 2)

- Para o exterior, e sobretudo para o mercado europeu, a gente decidiu ir somente com Lilica Ripilica, porque o metro quadrado é muito caro e você precisa otimizar (CC 6)

- Ficamos cinco anos tentando entrar, e conseguimos entrar somente agora, usamos essa feira também para prospectar franquias e abrir clientes multimarca, e tem tido um resultado bastante interessante \{Firenze $\}$ (CC 6; EU 1; EU 2)

- já tinha essas pessoas como distribuidores do canal multimarca, quando decidimos entrar na Europa com lojas, nós fomos primeiro falar com eles (EU 10; EO 4)

- $\quad$ sempre escolhemos em cada país um máster-franqueado (EU 1; EU 2; EO 4)

- $\quad$ Montamos um escritório nos arredores de Milão, (EO 2; GC 3)

- $\quad$ montamos uma loja conceito, uma flagship store na Via Della Spiga, que faz parte do quadrilátero da moda. (PE 8; CC 6)

- $\quad$ não vamos entrar num país diretamente com franquia, com loja monomarca, sem antes testar o produto no canal multimarca (EU 1; EU 2; CC 6)

- O papel que ela \{loja própria do México\} cumpre basicamente é de showroom, tem todas as nossas marcas dentro (CC 6)

- $\quad$ feiras internacionais. (CC 6; EU 1; EU 2)

- $\quad$ Milão \{ponto próprio\} (CC 6; IN 4)

- $\quad$ México \{ponto próprio\} (CC 6; IN 4)

- $\quad$ A gente só não tem mais lojas, porque tem que achar o espaço \{América do Sul\} (CC 5) - queremos é ter rede de lojas, vender em multimarca é um processo, é uma conseqüência, é uma necessidade inicial, mas nós queremos ter rede de lojas (CC 6)

- $\quad$ temos que estar com corners dentro dessas redes (EU 1)

- $\quad$ No México, decidi não entrar com loja (EN 1; EU 1)

- $\quad$ testar o produto no canal multimarca. (CC 2; EU 1)

- tem a responsabilidade de desenvolver a rede localmente \{função do másterfranqueado (EO 4; EU 10) 
- um máster-franqueado que vive na Guatemala, e tem o compromisso de desenvolver nos principais países da América Central. (EU 10; EO 4)

- $\quad$ todo o máster-franqueado tem que abrir a primeira loja própria (EO 4)

\section{d) Como se adaptar ao novo local - o que foi feito para se adaptar:}

- $\quad$ O padrão exigido lá fora é diferente do que a gente tem aqui. (EU 8)

- quando nós começamos tínhamos uma paridade cambial hoje o euro valendo R\$2,60 é bem complexo, o nosso nível de rentabilidade caiu (CC 5)

- $\quad$ a operação do México só vai crescer se o houver o ajuste da taxa lancelare (CC 5)

- O Brasil é difícil de exportar manufaturado, então nós estamos numa fase inicial (CC 5; EU 2)

- $\quad$ No Líbano, a gente pegou o mesmo conceito brasileiro, mas vamos mudar (CC 6)

- $\quad$ levamos representantes o México porque é bem difícil de mão-de-obra (AI 5)

- De lá \{Via Della Spiga\}, não são funcionários nossos, é um escritório europeu, lá. Um escritório italiano e que trabalha integrado com os nossos estilistas no Brasil. A gente começou a fazer esse trabalho para melhorar a performance na loja (CO 1; CO 2; GC 3)

- $\quad$ Na Itália, temos uma assessoria de comunicação que nos ajuda em toda a Europa (CC 6; EU 2; EU 9)

- $\quad\{$ Colômbia $\}$ é o único lugar do mundo, eu tenho que ter roupa de verão e de inverno o ano inteiro (EU 2)

- Europa ainda não, porque tem uma série de adaptações a serem feitas, então nós estamos nessa fase (CC 6)

- através da experiência a gente tem identificado essa necessidade de ter distribuidor, e esse distribuidor vira o nosso máster-franqueado (EU 2)

- $\quad$ nossos franqueados internacionais vêm para o Brasil, recebem treinamento na língua deles, trazem seus funcionários. (GC 3; CO 1; CO 2)

- na Europa nós temos um consultor de campo, a cada dois meses ele está num país, acompanhando a troca de produto, a troca de estação. (GC 3; CO 1)

- $\quad$ Acompanha à distância e localmente. (GC 3; EO 2)

- Essa loja própria precisa funcionar bem para expandir a rede. \{função do másterfranqueado $\}$ (EU 2)

- é importante que monte uma equipezinha de vendas...que faça venda no canal multimarca, \{função do máster-franqueado\} (EU 2) 
- $\quad$ na Espanha nem tanto \{nem tão bem\}, e a gente percebe que isso tem a ver com o nível do conhecimento da marca no país (CC 4)

- $\quad$ percebemos que não era uma boa, porque o México tem uma dependência muito forte de grandes lojas de departamento, de grandes redes, como é o caso de Palácio de Erro, Liverpool, Fábrica de Francia, Sears (EU 2)

- nós fomos para o México querendo copiar o modelo brasileiro e quebramos a cara (EU

2)

- $\quad$ identificamos a necessidade de aprimorar a coleção para o mercado europeu. (CC 2; EU

2)

- $\quad$ Hoje nós temos um estúdio de design italiano (EO 1; GC 1)

- $\quad$ ajustar todos os problemas das operações atuais (EO 2; CC 1)

- $\quad$ não abrir nenhuma loja antes de ter a operação redonda. (CC 6)

- $\quad$ a receita do bolo para um lugar, não é igual para o outro (EU 2)

- já com esses erros, que nós fomos cometendo ao longo do processo, nós começamos a: "Não, espera um pouco, vamos analisar detalhadamente as características de cada país, para a gente poder ingressar" (EU 2)

- foi uma fase inicial, teve o objetivo de criar internamente, na Marisol, uma cultura exportadora, que talvez a gente não tinha ( $\mathrm{CO} 1 ; \mathrm{CO} 2)$

- $\quad$ estamos numa fase de fazer as lojas serem bem operacionais, para daí fazer com que elas cresçam em quantidade (CP 8; EO 2)

- Temos metas de rentabilidade de loja, de volume de negócios, de vendas para fazer aumentar o número de lojas (CC 6)

- $\quad$ no México, quatro são brasileiros. (GC3; CO 1)

- $\quad$ sempre equipes locais (EO 3)

- $\quad$ escritório na Itália tem três funcionários, um gerente responsável, uma pessoa que cuida da parte de relacionamento com os clientes e com os representantes (EO 1; EO 2)

- As vendas todas que nós fazemos para outros países da Europa, nós fazemos diretamente via Brasil com a assessoria e apoio do escritório na Itália, nossa base de suporte para toda a Europa e Oriente Médio (EO 1) 


\section{APÊNDICE 7: ENTREVISTA MORANA (8/2/2008)}

\section{Bloco I - Caracterização do entrevistado}

\section{Qualificação do entrevistado:}

Nome da empresa:

- Grupo Ornatus

Setor de atividade:

- Acessórios, criamos uma forma diferente de vender bijuteria.

\section{Nome do entrevistado:}

- Jae Lee

\section{Cargo que ocupa na empresa:}

- Sócio da empresa

Seu papel no processo de internacionalização da empresa:

- $\quad$ encabeçando esse projeto dentro da empresa

\section{Bloco II - Processo de internacionalização da empresa}

\section{Processo de internacionalização - Tematização:}

a) Por que sair - razão de se internacionalizar:

- $\quad$ o europeu, americano, asiático vêem o mundo como um mercado (AI 1; EU 3)

- um grupo às vezes surgem algumas idéias, as visões são diferentes, diretor de marketing, diretora financeira, meu irmão, envolve as esposas, experiências diferentes podem ajudar a tomar decisões mais corretas (CO 1; CO 2)

- $\quad$ globalização (CC 3; CC 4)

- $\quad$ estamos buscando um novo mercado para esse conceito que já foi testado no mercado brasileiro (PM 7; CP 6)

- nem que a economia, a globalização, fossem a favor, não sei se a gente estaria preparado para pegar essa oportunidade. (CC 5; CC 6)

- $\quad$ tem muito a ver com o estágio de evolução de maturidade profissional, pessoal que o grupo adquiriu (CO 1; CO 2)

- aqui vai chegar um ponto que a rede vai saturar (CC 5)

- $\quad$ o mercado maior está lá fora (PM 7; CC 5)

- $\quad\{$ Brasil $\}$ É a logística, assalto, roubo, violência. (CC 5) 
- no mercado americano, europeu as preocupações são internas, depende da minha capacidade de gestão. (CC 5)

- $\quad$ Aqui eu dependo da minha capacidade, sorte, governo. (CC 5)

- $\quad$ fator externo tira muito as minhas oportunidades (CC 5)

- $\quad$ Lá fora, o governo não me atrapalha, me ajuda. (CC 5)

- $\quad$ interferência muito grande do governo (CC 5)

- governo sempre protegeu algumas indústrias, alguns setores. (CC 5)

- $\quad$ o momento não foi dos melhores da economia brasileira \{os últimos cinco anos\} (CC 5)

\section{b) Para onde ir (por que esse local):}

- vamos ter trabalho para montar o projeto tributário internacional, tem que fazer viagem, se voar mais quatro horas, estamos na Europa, se igual a mais tantas horas estamos nós Estados Unidos, vamos para os mercados onde realmente é o jogo onde joga players profissionais. (CC 1; CC 3)

- $\quad$ Portugal por ser Europa, (CC 6; EU 2; EU 4)

- $\quad$ a língua e a cultura de shopping center \{Portugal\} (EU 3; EU 4)

- $\quad$ não encontramos nenhum player com esse posicionamento \{da Morana\}, no mercado americano e europeu. (CC 3)

- $\quad$ questão pessoal (EN 1)

- $\quad$ pelo tamanho do mercado americano. (CC 5)

- $\quad$ Porto temos o parceiro local (CC 5; EU 10)

- $\quad$ Soho foi para capitalizar (CC 6)

- $\quad$ um pouco de vaidade, Nova York, Soho, traz um glamour pra marca. (CC 6)

- $\quad$ uma oportunidade de operador e ponto, circunstância (CC 5)

- A partir do momento que eu consigo colocar cidades cosmopolitas, vem o mundo inteiro te procurar. (PE 8; CC 5)

- $\quad$ Nova York, Los Angeles, são vitrines (PE 8)

- A partir do momento que você colocou o pé em Portugal, eu recebo consultas de Espanha, (PE 8; CC 5)

- $\quad$ mais duas, três lojas próprias em Los Angeles \{projeto de expansão\} (CC 6)

- vão surgindo “n” oportunidades que não estão nos meus planos (CC 5)

- $\quad$ proposta de expansão no mercado americano, em cinco anos abrir 5 mil lojas. (CC 6)

- $\quad$ Madri estamos prospectando. (CC 6) 
c) Como entrar - modos de entrada escolhidos:

- $\quad$ um ano de preparação, tiveram séries de viagens para o exterior (CC 6; EU 2)

- bati na porta de muitas empresas brasileiras que passaram por processo de internacionalização. (...) (EU 2; EN 1; EN 3)

- $\quad$ chegar muito humilde e sem nada. (...) aprender tudo de novo. (EU 2)

- $\quad$ buscamos parceiro em Portugal, não queríamos as primeiras lojas-pilotos a $300 \mathrm{~km}$ deles \{parceiro\} (CC 6)

- $\quad$ Algumas lojas precisam ser próprias, (EU 2; IN 4; IN 5)

- $\quad$ a loja-piloto tem essa função de testar o mercado, ajustar o negócio. (EU 1; EU 2)

- Em Nova York, estamos entrando com a mercadoria em algumas campanhas de massa de marketing. (CC 6)

- $\quad$ Não é franquia (CC 6)

- $\quad$ tento entender como o mercado funciona, (EN 1; EU 2)

- $\quad$ qual é desejo, necessidade da população, ou do público que você quer atingir (EU 8)

- $\quad$ viajamos em cinco pessoas, um grupo com focos diferentes (CO 1; CO 2)

- Rodamos os shoppings de Portugal até a fronteira com a Espanha, mapeamos todos os concorrentes (EU 7; CC 3)

- com essas visitas de prospecção a gente consegue fazer algumas adaptações que a gente acredita que dê certo no mercado europeu. (EU 2; CC 6)

- a gente visita, volta para cá, faz algumas adaptações dentro da nossa crença, desenvolvemos, consolidamos e concretizamos essa loja com as adaptações (EU 2; CC 6)

- $\quad$ nos Estados Unidos, cada estado tem lei de franquia. (CC 5; EU 11)

- $\quad$ A exigência é maior pelas duas partes. (EU 2)

- Quase um ano, visitando, mexendo, inúmeras reuniões com advogados, (EU 2; EU 11)

- tivemos que estruturar a parte tributária, a parte de logística, montar uma equipe internacional aqui dentro (EO 1; EO 2)

- $\quad$ é outra língua, (EU 4)

- $\quad$ outra cultura (EU 3)

- $\quad$ coleções se invertem, dia dos namorados, (EU 2; EU 8)

- $\quad$ investir \{franqueado ou máster-franqueado (CC 6)

- $\quad$ informações locais \{franqueado ou máster-franqueado\} (EU 2)

- $\quad$ conhecimento de varejo, mercado (EU 2; CC 6)

- $\quad$ Los Angeles \{loja própria\} (IN 5; EU 2)

- $\quad$ Portugal, praticamente \{loja própria\} (IN 5; EU 2) 
- $\quad$ tomada de decisões, é baseado na experiência, (EU 2)

\section{d) Como se adaptar ao novo local - o que foi feito para se adaptar:}

- $\quad$ não temos experiência em comércio de rua. (EU 2)

- $\quad$ a gente fala que é licenciado, já sai da lei de franchising americano (EO 1)

- $\quad$ o meu negócio dentro do ambiente americano, eu preciso dessas adaptações, eu preciso de um operador local, que me ajude nessa tropicalização (EU 2)

- a gente vai investindo com informações da nossa experiência do nosso negócio (EU 2;

$\mathrm{CO} 1 ; \mathrm{CO} 2)$

- montamos um grupo de trabalho internacional, as pessoas contratadas internamente são todas bilíngües, até três línguas, foram formadas para dar respostas rápidas. (CO 1; GC 2)

- $\quad$ Nós viajamos daqui pra lá, pra fazer supervisão (GC 3; EO 2)

- mandar pessoas daqui para formar gente local e que volte depois de um tempo e essa pessoa vai desenvolver um executivo local para estar tocando. (CO 1; $\mathrm{CO} 2 ; \mathrm{GC} 1)$

- $\quad$ quando errado, a velocidade de ajuste tem que ser muito veloz. (EU 2)

- montamos esse grupo com senso de urgência, a gente senta semanalmente, ou quinzenalmente pra ver o que está acontecendo, entender a composição e depois disso montar um plano de expansão (GC 1)

- Minha turma ficou lá quase três meses, mas antes disso eles vieram e ficaram um mês aqui, esta interação tem que existir permanentemente, constantemente principalmente nessa fase inicial. (GC 1; $\mathrm{CO} 1 ; \mathrm{CO} 2)$

- $\quad$ Não (funcionários expatriados) (EO 2)

- Daqui para lá, algumas coisas de lá para cá (abastecimento dos pontos internacionais) (EO 1; EO 2) 


\section{APÊNDICE 8: ENTREVISTA MUNDO VERDE (25/3/2008)}

\section{Bloco I - Caracterização do entrevistado}

\section{Qualificação do entrevistado:}

Nome da empresa:

- $\quad$ Mundo Verde

Setor de atividade:

- Lojas de produtos naturais e bem-estar

\section{Nome do entrevistado:}

- Jorge Eduardo Antunes da Silva

\section{Cargo que ocupa na empresa:}

- $\quad$ Sócio fundador

Seu papel no processo de internacionalização da empresa:

- $\quad$ Eu tomei a frente deste projeto, fui coordenador e continuo sendo coordenador dele

\section{Bloco II - Processo de internacionalização da empresa}

\section{Processo de internacionalização - Tematização:}

a) Por que sair - razão de se internacionalizar:

- E a gente constantemente recebe pedidos de pessoas de várias partes do mundo querendo levar a franquia Mundo Verde para os seus respectivos países (CC 5)

- $\quad$ Em conjunto os interessados e o pessoal da diretoria do Mundo Verde (CC 5)

- $\quad$ as lojas de Salvador e Rio de Janeiro são muito visitadas por turistas de diversos países (CC 5)

- $\quad$ Mundo Verde é uma empresa que tem bastante chance no mercado exterior (CC 5)

- $\quad$ sugestões e pedidos de clientes (CC 4)

b) Para onde ir (por que esse local):

- $\quad$ é um negócio diferenciado, nós fomos a primeira empresa no mundo que colocou no varejo a saúde do corpo e da mente (PE 1)

- $\quad$ Nós lidamos com a busca da beleza, a busca do bem-estar e qualidade de vida, tudo isso são tendências internacionais (PE 1)

- $\quad$ Investidor português com oportunidade de o Mundo Verde iniciar na Europa, (CC 5)

- $\quad$ muitos clientes de Angola são excelentes clientes das nossas lojas (CC 5) 
- $\quad$ laços culturais e históricos com o Brasil \{Angola, Portugal\} (EU 3)

- $\quad$ mercado em ascendência (CC 5)

- $\quad$ mercado carente de qualquer produto. (CC 5)

- $\quad$ poder aquisitivo (CC 5)

- $\quad$ o norte de Portugal é uma região mais próspera que o Centro e o Sul. (CC 5)

- $\quad$ a economia forte. (CC 5)

- $\quad$ cidade do Porto é mais empreendedora (CC 5)

- $\quad$ fomos procurados por um empresário angolano (CC 5)

- $\quad$ máster-franquia (EU 1; EU 2; CC 6)

- $\quad$ a visitação de nosso site de Angola era bastante expressiva (CC 5)

- $\quad$ a grande demanda do produto (CC 5)

- $\quad$ o português gosta muito do produto brasileiro (EU 8)

- $\quad$ a segunda e a terceira loja de Angola \{projeto de expansão\} (CC 6)

- $\quad$ Lisboa, no Norte e no Centro \{projeto de expansão\} (CC 6)

- $\quad$ ir a um ou dois países por ano, \{projeto de expansão\} (CC 6)

- $\quad$ em breve vamos entrar no terceiro país \{projeto de expansão\} (CC 6)

- $\quad$ fim de maio a primeira loja em Portugal \{projeto de expansão\} (CC 6)

c) Como entrar - modos de entrada escolhidos:

- $\quad$ em Portugal vamos enfrentar uma concorrência grande, organizada, (CC 3)

- $\quad$ fazer os registros de todos os produtos em Portugal. (CC 1)

- $\quad$ exportamos a marca, o know-how, o saber fazer, (EO 2; GC 3)

- $\quad$ exportamos todas as mercadorias, mobiliário (EO 2; GC 3)

- $\quad$ exportamos todos os equipamentos da loja $\{$ Angola\} (EO 2; GC 3)

- $\quad$ exportamos marceneiro, pedreiro, eletricista \{Angola\} (EO 2; GC 3)

- $\quad$ exportamos material de construção, de lá foi só cimentaria \{Angola\} (EO 2; GC 3)

d) Como se adaptar ao novo local - o que foi feito para se adaptar:

- $\quad$ os salários são altíssimos e é difícil encontrar pessoa responsável e competente (AI 5)

- $\quad$ Não tivemos dificuldade no transporte, (CC 5)

- $\quad$ Não tivemos dificuldade na legalização dos produtos. (CC 5)

- $\quad$ Existe transporte aéreo três vezes por semana, (CC 5)

- $\quad$ o transporte de navio é uma vez por mês (CC 5) 
- Nós temíamos isso também, excesso de burocracia, corrupção, esse tipo de coisa, mas não tivemos dificuldade nenhuma, muito pelo contrário (EU 2; EU 11)

- $\quad$ O modelo \{de loja\} é parecido, com algumas adaptações ao mercado local (EU 2; CC 6)

- $\quad$ O mix de produtos, existem algumas adaptações (CC 2)

- Existe uma série de produtos, que não podem ser vendidos no Brasil e vendem na Alemanha, Canadá, Estados Unidos, Dinamarca. Esses produtos a gente coloca na operação de Angola e Portugal (CC 2; EU 2; EU 11)

- $\quad$ Nós montamos uma trader específica para fazer operação internacional (EO 2)

- $\quad$ Nós colocamos no mesmo container 3 mil itens de 200 fornecedores diferentes (EO 2)

- $\quad$ O produto custa na prateleira entre cinco e dez vezes mais do que aqui (CC 5; CC 6)

- nosso funcionário vai passar dois meses lá, acompanhando a operação no início \{Portugal\} (GC 3; CO 1)

- nós não temos medo do abastecimento das lojas em algum outro local, porque conseguimos vencer essas dificuldades (EU 2)

- $\quad$ em Angola o gerente de loja (GC 3; CO 1)

- $\quad$ Em Portugal, vamos levar o gerente (GC 3; CO 1)

- $\quad$ tem mais sete de lá \{Portugal\} (GC 3; CO 1)

- Portugal, 45\% dos produtos vão ser do Brasil, e 55\% adquiridos lá mesmo (EO 1)

- $\quad$ Angola todo o produto é importado. (EO 1)

- $\quad$ Consolida aqui, já vai para lá tudo separadinho (EO 2; GC 3) 


\section{APÊNDICE 9: ENTREVISTA NOBEL (22/4/2008)}

\section{Bloco I - Caracterização do entrevistado}

\section{Qualificação do entrevistado:}

Nome da empresa:

- $\quad$ Livraria Nobel

Setor de atividade:

- Livraria e papelaria

Nome do entrevistado:

- $\quad$ Sérgio Milano

\section{Cargo que ocupa na empresa:}

- $\quad$ Diretor de operações

Seu papel no processo de internacionalização da empresa:

- $\quad$ responsável área de franquias, internacionalização, manutenção do relacionamento com parceiros

\section{Bloco II - Processo de internacionalização da empresa}

\section{Processo de internacionalização - Tematização:}

a) Por que sair - razão de se internacionalizar:

- $\quad$ vieram candidatos de fora, primeiro portugueses (CC 5)

- $\quad$ começamos a receber muitos e-mails de candidatos (CC 5)

- $\quad$ eu comecei a achar que tinha espaço para tentar desenvolver um pouco o nosso negócio por lá (EN 1)

- $\quad$ apesar de ter muito crescimento para ser feito dentro do país, vemos com bons olhos a chance de explorar a marca em outros locais (CP 4; PE 1; PM 7)

- $\quad$ a gente estava preparado para isso (CC 1)

b) Para onde ir (por que esse local):

- a língua \{fator que determina a escolha de um país\} (EU 4)

- $\quad$ Portugal tinham muitos candidatos. (CC 5)

- $\quad$ Espanha pela proximidade (EU 3)

- $\quad$ presença de espanhóis no Brasil (EU 3)

- $\quad$ os livros, os editores são os mesmos \{Espanha e América Latina\} (CC 5; EU 9) 
- $\quad$ Os angolanos têm uma influência muito grande no Brasil (EU 3)

- $\quad$ não tem indústria editorial forte local, tem muito pouco livro feito em Angola, quase tudo é importado do Brasil e de Portugal (PE 1; CC2; CC 3; CC 5)

- $\quad$ maior a dependência deles conosco do que outros países (CC 5)

- $\quad$ teve um pouco essa coisa do latino, no caso de Portugal e Espanha (EU 3)

- $\quad$ Tem que lembrar que na Espanha eu não vendo livros em português, vendo livros em espanhol, os franqueados compram dos editores espanhóis (EO 4)

- $\quad$ uma segunda e uma terceira loja em Angola \{projeto de expansão\} (CC 6)

- $\quad$ Argentina \{projeto de expansão\} (CC 6)

- $\quad$ Colômbia \{projeto de expansão\} (CC 6)

- $\quad$ Estados Unidos \{projeto de expansão\} (CC 6)

\section{c) Como entrar - modos de entrada escolhidos:}

- $\quad$ tomamos a iniciativa de expor em uma feira de franquias na cidade do Porto (CC 6; EU

1)

- $\quad$ em todos os lugares a gente cresce através de máster-franqueados. (EO 4; EU 2; CC 6)

- $\quad$ tendo uma pessoa forte na Espanha, estaria capacitando a Nobel para expansão futura nos outros países da América Latina. (CC 6; EU 2)

- $\quad$ Nos Estados Unidos abrir uma livraria latina, \{português, espanhol\} (CC 5; CC 6)

- depois na hora da montagem das unidades lá, o nosso pessoal de operações aqui é que foi montar (EU 2; GC 3)

- $\quad$ no México a gente utiliza a marca Gandhi lá, a marca deles mesmos, porque já era uma marca muito conhecida lá (PM 1)

- $\quad$ E nos outros três países utiliza-se a marca Nobel (PE 1; CC 6)

- a burocracia, (CC 5)

- $\quad$ registrar a sua marca, (CC 5)

- $\quad$ ter todos os contratos feitos de acordo com a lei do país (CC 6; EU 11)

- $\quad$ o nosso máster-franqueado espanhol já era do ramo (EU 10; CO 1)

- converteram suas lojas ao modelo da Nobel (PE 1)

- $\quad$ já tinha contato com fornecedores (EN 2; EU 1)

- $\quad$ a pessoa tem que ter o perfil, o capital necessário para investir, (CC 6; EU 2)

- $\quad$ ser dono da primeira loja \{função do franqueado ou máster-franqueado\} (CC 6)

- $\quad$ negociar com os fornecedores \{função do franqueado ou máster-franqueado (CC 6)

- $\quad$ selecionar os novos franqueados \{função do máster-franqueado\} (CC 6) 
- $\quad$ treinamento para os franqueados \{função máster-franqueado (CC 6)

- $\quad$ feira (CC 6; EU 1)

d) Como se adaptar ao novo local - o que foi feito para se adaptar:

- $\quad$ O treinamento do máster (GC 3; CO 1; CO 2)

- $\quad$ suporte (GC 3; CO 1)

- $\quad$ México, utilizam fornecedores locais (EO 4)

- $\quad$ Espanha, compram dos editores espanhóis (EO 4)

- $\quad$ eu organizo os fornecedores para eles venderem direto para cada loja (EO 2) 


\section{APÊNDICE 10: ENTREVISTA O BOTICÁRIO (4/4/2008)}

\section{Bloco I - Caracterização do entrevistado}

\section{Qualificação do entrevistado:}

Nome da empresa:

- O Boticário

Setor de atividade:

- $\quad$ Setor de cosméticos

Nome do entrevistado:

- $\quad$ Roberto Garcia Neves

Cargo que ocupa na empresa:

- Diretor internacional

Seu papel no processo de internacionalização da empresa:

- $\quad$ expatriar modelo de negócios, pessoas, tecnologia de negócios, nossa marca,

\section{Bloco II - Processo de internacionalização da empresa}

\section{Processo de internacionalização - Tematização:}

a) Por que sair - razão de se internacionalizar:

- $\quad$ vaidade natural (EN 1)

- $\quad$ o processo de buscar alternativas de mercados (PM 7)

- os acionistas tiveram a curiosidade de experimentar esse mesmo modelo em outros mercados (EN 4)

- $\quad$ muitas pessoas começaram a bater na nossa porta (CC 5)

- Uma presunção também de que um negócio que está dando certo no Brasil, potencialmente poderia ter sucesso lá fora (CC 6)

- Uma empresa totalmente sadia financeiramente, que se autogere, se auto-sustenta financeiramente (CC 1)

- $\quad$ começamos a ter essa ambição ingênua, pueril (CC 6)

- $\quad$ marca Brasil é difusa. (CC 5)

- $\quad$ falta estratégia de internacionalização da marca Brasil (CC 5) 


\section{b) Para onde ir (por que esse local):}

- $\quad$ não era um processo que a gente estabelecia o que queria e para onde iria. Não era direcionado, não posso dizer que ele era um processo reativo, a gente podia ter o critério de escolher (CC 5)

- $\quad$ escolhemos países que poderiam ser uma vitrine para a gente, que pudessem dar um foco mais estruturado para o nosso negócio (CC 6)

- país que a gente tenha condições de construir uma marca em um processo mais internacionalizado (CC 6)

- Se a minha marca tiver em locais que tenham produtos de notoriedade cosmética já facilita uma aproximação dos consumidores (CC 2; CC 4)

- (...) conquistar o mercado latino-americano para conquistar o mercado americano de varejo (CC 6)

- $\quad$ falar português seria muito mais fácil para o processo de internacionalização (EU 4)

- $\quad$ achando que o sucesso daqui é o sucesso lá fora, com despreparo, (EU 2)

- $\quad$ a gente teve operações na Bolívia (CC 6)

- $\quad$ América Latina tínhamos pequenas operações, algumas tentativas (CC 6)

c) Como entrar - modos de entrada escolhidos:

- Vamos entender qual é o canal correto de cada um desses mercados e vamos nos adaptar (EU 2)

- $\quad$ informal $\{$ como se iniciou a saída\} (CC 5)

- $\quad$ primeiro no modelo com loja. (CC 6)

- $\quad$ primeira fase foi tentar fazer uma operação de franquia (EU 1)

- É uma grande caixa preta para um país com uma cultura de economia fechada como o Brasil (EU 3)

- $\quad$ loja custa muito caro (CC 6)

- $\quad$ começaram a aparecer produtinhos do Boticário durante o enredo da novela (...) (CC 6)

- $\quad$ Venezuela, outro modelo de negócio (EU 2; CC 6)

- $\quad$ entrava com uma loja muito em cima das necessidades, querendo que a loja desse certo para abrir uma segunda, uma terceira e tentar replicar o que foi no Brasil (EU 2; CC 6)

- Abrir uma loja para a esposa trabalhar, não tinha capacitação técnica nem financeira para poder crescer (CC 5) 


\section{d) Como se adaptar ao novo local - o que foi feito para se adaptar:}

- mas o modelo de franquia era um conceito que não era entendido em Portugal naquele momento e no final a gente concentrou aquela operação em uma operação única, a gente tirou o modelo de franquia e fizemos um grande licenciamento da operação local com uma pessoa (EU 6)

- $\quad$ segunda fase, que foi a fase de ter de uma concessionária, de um licenciamento da marca, com algum tipo de guidance, com um tipo de orientação, um pacote de serviços com regras do jogo (EU 1; CP 6; CC 6)

- temos que buscar outras plataformas porque é um ótimo aprendizado, quando nós falamos de perspectiva maior, de estratégia internacional. (EU 2)

- $\quad$ precisava de um modelo sofisticado processo (CC 6)

- a gente precisa dar uma capacidade de fundo de caixa que rentabilize o negócio dele...então a gente criou o modelo T, de tamanho. T1 um epicentro de mix de produtos, mobiliário, treinamento, campanha de comunicação, no máximo 20 e poucos itens e que pode entrar em uma multimarca (EU 1; EU 2; CP 6; GC 3; CO 1; CO 2)

- $\quad \mathrm{T} 2$, englobava o T1, um mobiliário maior, um mix maior (EU 1; CP 6; CC 6)

- $\quad$ T4 é a nossa loja. (EU 1; CP 6; CC 6)

- geração 2.0 tentativa de industrialização do processo internacional, ter o calendário de campanhas internacionais (EU 1; CP 6; CC 6)

- um grupo pensante exclusivamente naquele mercado \{México\} para viver todo o processo de tropicalização (EU 2)

- $\quad$ trabalhamos efetivamente com a população de lá para fazer uma boa tradução com o consumidor local (EU 2; CO 1)

- $\quad$ os mesmos produtos com comunicações adaptadas para a cultura portuguesa (CC 2; EU 3)

- a gente começou a ter enxovais para as lojas, material de trade marker, campanhas, filmes, materiais que poderiam ser de campanhas e de prateleiras (CC 6)

- franquia, as pessoas não entendiam o que era esse conceito, queriam muito colo, que a gente fizesse tudo e ela só comprava a loja (AI 5)

- $\quad$ procuravam vender de tudo dentro de uma loja do O Boticário, sem padronização (EU 6; AI 5)

- $\quad$ entrou e saiu $\{$ Bolívia\} (EU 2)

- $\quad$ vários enganos com essa experimentação e vimos que precisava de alguma coisa a mais \{México\}(EU 2) 
- o México não tem classe média, cosmético é vendido em dois canais, em lojas de departamentos e no mercado cinza, nossa loja é intimista, transmite uma coisa muito asséptica, inalcançável porque loja lá era sinônimo de boutique cara. (EU 2; EU 6; EU 8)

- Vim para o projeto de internacionalização do O Boticário, mas sou uma conseqüência das reflexões das necessidades de internacionalização da marca (CO 1)

- Não somente modelo de negócios, mas às vezes pessoas, mas expatriar nossa tecnologia de negócios, nossa marca, e a minha base maior é aqui (GC 3)

- Logo no comecinho da 2.0. Então, a gente começou a olhar assim: "Eu não preciso ir necessariamente com loja, eu tenho que buscar canais que já tenham notoriedade (EU 2)

- a gente hoje consegue utilizar essa experiência para ser muito mais criterioso em nossos processos, estratégias (EU 2; CO 1; CO 2)

- $\quad$ o português de Portugal é diferente do português do Brasil (EU 4)

- Portugal é um ótimo aprendizado, quando nós falamos de uma perspectiva maior, de uma estratégia internacional (EU 2)

- a gente cresce muito mais com essas 20 lojas, em um mercado que economicamente diminui (CC 5)

- começava a ler alguma literatura, se integrar no processo entender um pouco mais, isso deu uma organizada muito grande para toda a nossa operação, (EU 2)

- $\quad$ A gente tem que ser um pouco mais estruturado ao invés de ficar recebendo paisinhos escolhemos países que poderiam ser uma vitrine para a gente, que pudessem dar um foco mais estruturado para o nosso negócio (CC 6)

- $\quad$ entender o canal correto de cada um desses mercados e nos adaptar. (EU 2; EU 6)

- calendário de campanhas internacionais (EO 1)

- $\quad$ política de lançamentos muito bem esclarecida (EO 2)

- $\quad$ ter pessoas especializadas (CO 1)

- campanhas contratando agências internacionais (CC 6)

- $\quad$ multiplicar os mesmos números de dinheiro (CC 6)

- $\quad$ não ter perda de dinheiro, ter margens operacionais, reinvestir na nossa própria operação $(\mathrm{CC} 6)$

- processo de profissionalização muito de dentro para fora, dando capacidade de metodologia de trabalho, escolha de um parceiro (GC 3)

- A versão nossa 3.0 treina pessoas, gera reflexões, pessoas viajam, pessoas olhando lojas, fazendo treinamento pesquisando quais são as melhores oportunidades, melhores 
valores, onde poderia ser mais oportuno para o modelo O Boticário. (CP 6; EU 2; EU 1; GC $3 ; \mathrm{CO} 1 ; \mathrm{CO} 2)$

- $\quad$ duas \{funcionários expatriados\} $(\mathrm{CO} 1 ; \mathrm{CO} 2)$ 


\section{APÊNDICE 11: ENTREVISTA SPOLETO (25/4/2008)}

\section{Bloco I - Caracterização do entrevistado}

\section{Qualificação do entrevistado:}

Nome da empresa:

- $\quad$ Spoleto Franchising

Setor de atividade:

- $\quad$ Franquia de alimentação

\section{Nome do entrevistado:}

- $\quad$ Antônio Bento Moreira Leite

\section{Cargo que ocupa na empresa:}

- Gerente de expansão internacional

\section{Seu papel no processo de internacionalização da empresa:}

- $\quad$ prospecção dos possíveis candidatos a uma máster-franquia internacional, modelagem do projeto no país em questão, suporte ao projeto.

\section{Bloco II - Processo de internacionalização da empresa}

\section{Processo de internacionalização - Tematização:}

a) Por que sair - razão de se internacionalizar:

- $\quad$ desde o início havia intenção de levar o Spoleto para fora (CC 6)

- oportunidades de crescimento do nosso grupo eram: expansão dentro do território brasileiro; operar novas marcas dentro do território brasileiro; explorar a marca em novos canais; a expansão internacional (CC 5)

\section{b) Para onde ir (por que esse local):}

- $\quad$ facilidade da língua (EU 4)

- Contratualmente o pipeline de ponto é definido pelo máster, mas a decisão final sempre tem que ser chancelada pelo o Spoleto Brasil (EO 2; EO 4)

- $\quad$ a porta de entrada \{da Europa\} seria Portugal, pela facilidade da língua (EU 4)

- $\quad$ Península Ibérica abrir 50 lojas em cinco anos \{projeto de expansão\} (CC 6)

- $\quad$ entrar nos Estados Unidos \{projeto de expansão\} (CC 6) 


\section{c) Como entrar - modos de entrada escolhidos:}

- $\quad$ o operador do Spoleto fora do Brasil, conselho do grupo, naquele momento era formado pelos principais diretores que eram sócios da empresa, atualmente nós já temos diretores que não são sócios. (PM 1; EO 4)

- embora a decisão final passe pelo conselho, a gestão da negociação fica associada ao gerente da área internacional, junto com o presidente do grupo, até que o contrato esteja assinado (EO 2; EO 4)

- $\quad$ desde o início pensada em crescer via franquias (CC 6)

- o Spoleto se tornou sócio da Alsea no Brasil, em contrapartida, eles assumiram o compromisso de levar o Spoleto ao México (PM 1; EO 4)

- para entrar a Spoleto no México, foi através de um contrato de máster-franquia padrão (EO 4)

- quando a gente define os milestones é pensando diminuir esse período de desconhecimento (EU 2)

- $\quad$ e aumentar nível de faturamento inicial (CC 6)

- $\quad$ garantir a ocupação do território (PM 7; CC 6)

- $\quad$ e ganhar escala de negociação com os fornecedores (PM 2)

- $\quad$ e conhecimentos da marca (CC 6)

- nos Estados Unidos, um modelo de máster-franquias regionais, mas os principais mercados norte-americanos serão operados pelo Spoleto Brasil. Um grupo que possa introduzir o Spoleto nos Estados Unidos, pode se tornar dono da marca (EO 4; CC 6)

- mapeamos dos 100\% supply chain dos Estados Unidos, incluindo todos os fornecedores de insumo e equipamentos, já estabelecemos uma relação inicial com alguns players (EO 4; CC 6)

- $\quad$ ainda não tem definido qual vai ser o modelo de management, se vai ser um executivo do Brasil ou um executivo dos Estados Unidos (CO 1)

- $\quad$ oportunidade de nos associarmos do Grupo Alsea (CC 5)

- Alsea portava um network tremendo, tivemos o acesso a toda indústria, a toda cadeia de suprimentos, principalmente de realstate (PM 1; PM 2)

- $\quad$ começamos a estabelecer relações com um grupo máster-franqueado da Domino's da Guatemala, Índia (CC 6; PM 1)

- conhecemos o presidente do Burger King no sul da Europa que estava montando uma empresa e buscava conceitos no mundo que pudessem ser multiplicáveis na Península Ibérica, hoje é um máster-franqueado para a Península Ibérica (CC 5) 
- $\quad$ um grupo com uma experiência prévia em food service (EU 2; CC 6)

- $\quad$ com capital para sustentar no mínimo dois anos de operação (CC 6)

- $\quad$ suporte \{função Spoleto\} (GC 3)

- $\quad$ transferência de know-how (GC 3)

- $\quad$ no contrato de máster-franquia é definido o número de lojas que teriam que ser abertas em até cinco anos (CC 6)

- $\quad$ pagamento de royalties e taxa de abertura para o Spoleto Brasil \{função do franqueado ou máster-franqueado (CC 6)

- $\quad$ parte dos royalties e parte das taxas de abertura que por ventura tiver de subfranquias (CC 6)

- seguem tudo que orientamos, desde macroestratégia, até operacional \{função do franqueado ou máster-franqueado\} (CC 6)

- $\quad$ ter a experiência de ser máster-franqueado (CC 6; CO 1)

- $\quad$ nos Estados Unidos, um modelo de máster-franquias regionais, os principais mercados norte-americanos serão operados pelo Spoleto Brasil (EO 4)

- o restaurante tradicional, nos Estados Unidos é muito estruturado, casual, e tem "n" players, a maioria dessas empresas tem uma ambientação de loja sofisticada e existe uma proposta de valor muito forte para o cliente muito positiva. (CC 5)

\section{d) Como se adaptar ao novo local - o que foi feito para se adaptar:}

- $\quad$ existiam desafios com relação ao formato do negócio (CC 5)

- $\quad$ e com o fato de estarem fazendo o start up de uma marca desconhecida (CC 5)

- $\quad$ acesso a fornecedores de massa fresca com qualidade e preço, na Espanha (EO 4)

- $\quad$ encontramos uma qualidade de operação no nível loja formidável, padrões de processo de operação da loja Spoleto \{Espanha\} (EO 4)

- dada a proximidade e uma grande oferta de produto, qualidade e a baixo preço, com o lead time a Itália abastece a Espanha (EO 4)

- A gente acabou de contratar um escritório de arquitetura, para resolver o novo padrão (EU 2; CC 6)

- $\quad$ algumas adaptações no que se refere a alguns ingredientes e molho \{Espanha\} (EU 2; EU 8)

- no México, na realidade, agora, a gente acabou de concluir a compra de uma fábrica local, porque no Brasil nós também fabricamos a nossa massa fresca (IN 3) 
- $\quad$ negociação com um grupo português que veio ao Brasil, foi exposto a uma série de conhecimentos, de processos internos e acabou abrindo um clone nosso em Portugal (CC 5)

- o grupo gestor da Espanha é pouco alinhado conosco, toma decisão pouco compartilhada, resultou em abertura em pontos que o Spoleto Brasil entendia como não sendo os melhores para o projeto na Espanha. A informação chegava com o processo já encaminhado (EU 2; EU 6) - \{milestones - Espanha\} acaba ocasionando uma pressão de expansão no grupo por uma cláusula contratual (CC 6)

- negócio associado ao almoço executivo. A loja na Espanha foi em lugar sem nenhuma concentração de escritórios. Fechamos a loja três meses após a abertura. (EU 2)

- lidar com um grupo muito estruturado, isso forçou uma estruturação nossa de processos e de informação (EU 2)

- $\quad$ segunda loja na Espanha\} alertou tanto a nós, quanto ao grupo local quanto à necessidade desse alinhamento de visão nas decisões (EU 2)

- A expansão internacional, efeitos positivos na nossa estrutura doméstica: forçar a estruturação nossa para dar o suporte aos grupos internacionais; compartilhamento de melhores práticas; sofisticar o salão de nossas lojas, na programação visual (EU 2; CC 6)

- $\quad$ sabemos que o formato atual do Spoleto Brasil, não está adequada ao mercado norteamericano (EU 2; EU 6; EU 8; CC 5)

- Na Espanha, conseguimos atender esse público família, embora não seja o núcleo do nosso negócio (EU 8; CC 4)

- temos dois treinadores para início de projeto, eles ficam três meses morando no país \{expatriados\} (GC 3; CO 1)

- $\quad$ Atualmente não há nenhuma pessoa nossa \{expatriados\} (EO 2)

- México, fornecedor terceirizado no México e passamos todo o know-how de produção, fichas técnicas, linhas de produção, armazenagem (EO 1; EO 4) 


\section{APÊNDICE 12: ENTREVISTA VICTOR HUGO (30/1/2008)}

\section{Bloco I - Caracterização do entrevistado}

\section{Qualificação do entrevistado:}

Nome da empresa:

- Victor Hugo

Setor de atividade:

- $\quad$ Artefatos de couro

Nome do entrevistado:

- $\quad$ Luis Henrique Stockler

\section{Cargo que ocupa na empresa:}

- Consultor da empresa Internacionalização

\section{Seu papel no processo de internacionalização da empresa:}

- Identificar potenciais investidores pra marca fora do Brasil e dar todo suporte pra eles. Desde o contrato planos de negócios, identificação de vários potenciais de pré-implantações de lojas. Assessorar na importação dos produtos. Todo o suporte que se dá a esses investidores é por mim. Dentro da empresa quem cuida dos projetos sou eu

\section{Bloco II - Processo de internacionalização da empresa}

\section{Processo de internacionalização - Tematização:}

a) Por que sair - razão de se internacionalizar:

- Victor Hugo foi desbancado por essas marcas \{Prada, Vuitton, Gucci\} e tinha duas opções ou brigava com elas ou ele ia ser a primeira da segunda linha. Optou por brigar com as grandes (CC 3)

- $\quad$ o próprio Victor Hugo (EN 1)

- $\quad$ no Brasil tiramos o faturamento das grandes marcas (PE 1; CC 3)

- $\quad$ a marca ficar mais conhecida (CC 6)

- $\quad$ A Victor Hugo não era exportadora (CC 6)

- $\quad$ empresários de fora do Brasil querendo levar a marca (CC 5; PE 1)

- $\quad$ mostrar que era possível a internacionalização (PM 7)

- $\quad$ ter uma vitrine lá fora. (PM 7)

- $\quad$ o consumidor vê a Victor Hugo no mesmo grupo das internacionais. (PE 1) 


\section{b) Para onde ir (por que esse local):}

- $\quad$ enquanto ele não tivesse uma loja na Quinta ou na Madison, não ia vender uma peça fora do Brasil. (EN 1; EN 4)

- $\quad$ em 2005, 2006, a primeira loja, na Madison, de frente pra Dior, de frente pra Montblanc (...) (PE 8)

- $\quad$ os melhores designers eram italianos, abriu-se o escritório em Florença (PE6; CC 6)

- $\quad$ Nova York é a meca do consumo (PE 6; PE 8; CC 4)

- $\quad$ vitrine do mundo \{Nova York\} (PE 8; CC 4)

- $\quad$ o tapume da loja de Portugal trouxe esse pessoal (PE 1)

- $\quad$ A marca já ser conhecida Portugal (PE 1; CC 4)

- $\quad$ todos os pesos do mundo estão em Portugal. (CC 3)

- $\quad$ Na Espanha as marcas de bolsas são muito fortes (CC 2; CC 3)

- $\quad$ se quer competir com esses grandes ou com os grandes pesos, tem que competir na terra deles e ganhar escala (CC 3; CC 6)

- A América Latina tem mercado, (CC 4)

- cada dez pessoas que vão para Portugal fazer turismo, nove passam por dentro do Vasco da Gama, pela porta da Victor Hugo, não seria a melhor loja para vender, mas uma posição estratégica para Espanha, França, Alemanha, Inglaterra. (PE 8)

- $\quad$ Espanha hoje é, em termos de varejo, é um desbunde (CC 2; CC 3; PE 8)

- $\quad$ Madri é um pólo de tráfego enorme de pessoas da Europa inteira (CC 4; PE 8)

- $\quad$ Londres, pra criar referência e posicionamento da marca pra Europa (CC 6)

- $\quad$ o consumo do produto e de artigos de couro e de bolsas nos países, (CC 2; CC 4; CP 7)

- $\quad$ locais de tráfego e pontos de convergência de tráfego de pessoas. (CC 4; CC 6; PE 8)

- divulgar a marca, (CC 6)

- loja pra ganhar dinheiro a gente tem que ir pro shopping Caiscais, pra ali na Liberdade, que a gente vai fazer agora (CC 6)

- $\quad$ marcas vizinhas, as marcas com quem a gente quer brigar (CC 3)

- $\quad$ visibilidade do ponto (CC 6; PE 8)

- Nova York tem uma facilidade muito grande em termos de abastecimento de estoque (PE 7; CC 1)

- $\quad 33 \%$ da população de Portugal tem potencial pra comprar produto da Victor Hugo (CC 4)

- $\quad$ depois da loja na Madison começaram a surgir clientes nos Estados Unidos, varejistas pequenos, multimarcas e grandes redes (CC 5) 
- $\quad$ a loja da Madison é uma grande vitrine (PE 1)

- $\quad$ os portugueses conhecem as marcas dos shoppings do Nordeste \{brasileiro\}. (EU 8)

- $\quad$ duas lojas em Portugal. (EU 1; CC 6)

- $\quad$ cerca de 60 lojas na Europa nos próximos dez anos (CC 6)

- $\quad$ cidades menores, no Leste Europeu, (CC 6)

- $\quad$ o exterior tem que em dez anos ser o dobro ou o triplo do que é o Brasil (projeto de expansão) (CC 6)

- $\quad$ o projeto de Portugal é um projeto de dez anos \{projeto de expansão\} (CC 6)

c) Como entrar - modos de entrada escolhidos:

- $\quad$ no Brasil já trabalhava com modelos brasileiros reconhecidos internacionalmente (CC 5; CC 6)

- $\quad$ Madison \{ponto próprio\} (IN 3; IN 4; IN 5)

- $\quad$ tem que gostar de loja, varejo (AI 5)

- $\quad$ feiras (EU 1)

- $\quad$ franquia (EU 1)

- $\quad$ Nova York, multimarcas (EU 1)

- $\quad$ No ano que vem, operação na Espanha França, Itália, Londres. (CC 6)

- $\quad$ Madri, Barcelona é pra ter flagship (CC 6; PE 1)

- $\quad$ Paris, uma flagship (CC 6; PE 1)

- $\quad$ um grupo que quer pegar a expansão da Europa inteira, ... fazer as 60 lojas vão se associar a, Portugal; (EO 4)

- $\quad$ Estados Unidos pretende ampliar, não com loja própria, talvez com franquias... (EO 4; CC 6)

- a prioridade agora é a penetração que a gente tá ganhando em lojas como no Bal Harbour (CC 6)

- $\quad$ Miami com multimarcas \{projeto de expansão\} (CC 6)

- $\quad$ algumas centenas de multimarcas pela Europa \{projeto de expansão\} (CC 6)

\section{d) Como se adaptar ao novo local - o que foi feito para se adaptar:}

- $\quad$ cada vez ter menos loja própria e mais franquia (EO 4)

- gerenciar mais a marca e menos operação (EO 2)

- $\quad$ a pessoa que produz o mobiliário não pode pegar numa chave de fenda em Nova York, por causa de sindicato. (EU 11) 
- Você fecha o negócio com o shopping hoje e daqui a 30, 40 dias loja tá aberta $\{$ Brasil\}. Não existe \{Nova York, Portugal\} (EU 6; EU 11)

- a mão-de-obra lá não ta acostumada a prestar o serviço pra o cliente, são gentis, educados, mas distantes e pouco servis. (AI 5)

- $\quad$ com uma loja só, fazer uma campanha de marketing em Nova York é proibitivo é um preço estúpido (CC 1)

- o Ibama demora 40 dias pra certificar produtos (CC 1)

- $\quad$ padrão de atendimento brasileiro. Que é mais forte, é um conceito pra o mundo (CC 1;

CC 3)

- $\quad$ nos lançamentos, os investimentos de marketing beiravam US\$ $100 \mathrm{mil} / \mathrm{mês}$ (CC 1)

- $\quad$ a loja de Lisboa é a mais atualizada da Victor Hugo. (CC 6)

- $\quad$ A programação visual de móveis. (CC 6)

- $\quad$ programação visual de campanha é a mesma pra o mundo inteiro (CC 6)

- $\quad$ a marca Victor Hugo, dentro de Portugal, tem um bom conhecimento (PE 1; EU 8)

- $\quad$ estamos conseguindo posicionar a marca aonde a gente quer, do jeito que a gente quer (CC 6)

- levar gente do Brasil pra misturar um pouco essas culturas, fazer um blend, pra quebrar um pouco o jeito de ser, tanto americano quanto português. (AI 1)

- $\quad$ Em Portugal, com o aprendizado em Nova York, trabalhar basicamente com relações públicas e eventos focados em formadores de opinião (EU 2)

- alguns produtos tem que ser certificado e quando vão pra Nova York, já vão certificadas, pelo Ibama (EU 11)

- gente aprendeu que tem coisa que é melhor fazer no Brasil (EU 2)

- $\quad$ é uma logística toda que tem que ser aprendida, os processos têm que ser clareados, e mapeados (EU 2; EU 6)

- $\quad$ Portugal ou Nova York, às vezes, a Sedex não é o melhor caminho. Em Lisboa tem que usar DHL (EU 2; EU 6)

- $\quad$ tem brasileiros que moram lá que a gente pegou pra trabalhar (CO 1)

- $\quad$ Nova York a equipe é inteira brasileira que mora em Nova York (CO 1; CO 2)

- $\quad$ a loja de Nova York serve como um fornecedor de atacado pra outros varejos dentro dos Estados Unidos (EO 2)

- $\quad$ o Brasil faz a exportação pra Nova York (EO 1; EO 2) 
- Quem vende pra Portugal é Nova York quem fatura é Nova York a mercadoria sai do Brasil direto pra Portugal, mas a nota vai para Nova York. Tem uma triangulação por motivos tributários (EO 1)

- $\quad$ o estoque de peles exóticas pra alimentar o mundo inteiro tá em Nova York. (EU 2; EU 6; EO 1)

- $\quad$ a Itália alimenta \{óculos\} Portugal, Nova York (EU 2; EU 6; EO 1)

- $\quad$ O Brasil controla todos pedido (EU 2; EU 6; EO 2)

- $\quad$ material de marketing, que a gente produz em escala aqui no Brasil, (EU 2; EU 6; EO 2) 


\section{APÊNDICE 13: ETAPAS DE INTERNACIONALIZAÇÃO DAS EMPRESAS PESQUISADAS}

\begin{tabular}{|c|c|c|c|c|}
\hline Empresa & $1^{\mathrm{a}}$ saída & $2^{\mathrm{a}}$ saída & Demais saídas & $\begin{array}{l}\text { Próximas } \\
\text { expansões }\end{array}$ \\
\hline Arezzo & $\begin{array}{l}\text { - Exportação } \\
\text { (1990) }\end{array}$ & $\begin{array}{c}\text { - Paraguai/ } \\
\text { Franquia (2004) }\end{array}$ & $\begin{array}{l}\text { - Venezuela/ Franquia (2005) } \\
\text { - Arábia Saudita/Franquia } \\
\text { (2005; fechou em 2007) } \\
\text { - Portugal/Franquia (2007) }\end{array}$ & $\begin{array}{l}\text { - Arábia Saudita; } \\
\text { - Europa; } \\
\text { - China; } \\
\text { - América Latina; } \\
\text { - África }\end{array}$ \\
\hline $\begin{array}{l}\text { Carmen } \\
\text { Steffens }\end{array}$ & - Exportação & $\begin{array}{c}\text { - Paraguai/ } \\
\text { Assunción/ } \\
\text { Franquia (2001) }\end{array}$ & $\begin{array}{c}\text { - Uruguai/ Punta del Este/ } \\
\text { Franquia } \\
\text { - Portugal/ Franquia (2003) } \\
\text { - Estados Unidos/Los } \\
\text { Angeles/Franquia } \\
\text { - Austrália/Franquia (2007) }\end{array}$ & $\begin{array}{l}\text { - Argentina; } \\
\text { - Las Vegas; } \\
\text { - Espanha; } \\
\text { - Portugal; } \\
\text { - Austrália; } \\
\text { - Grécia; } \\
\text { - México; } \\
\text { - Estados Unidos }\end{array}$ \\
\hline $\begin{array}{l}\text { Chilli } \\
\text { Beans }\end{array}$ & $\begin{array}{l}\text { - Portugal/ } \\
\text { Máster-franquia/ } \\
(2002-2003)\end{array}$ & - Los Angeles & Não há & $\begin{array}{l}\text { - Estados Unidos; } \\
\text { - Alemanha; } \\
\text { - Dubai; } \\
\text { - Oriente Médio; } \\
\text { - Panamá; } \\
\text { - Colômbia; } \\
\text { - Venezuela; } \\
\text { - Chile; } \\
\text { - Europa (27 } \\
\text { países) }\end{array}$ \\
\hline $\begin{array}{c}\text { Lilica } \\
\text { Ripilica }\end{array}$ & $\begin{array}{c}\text { - Exportação } \\
\text { (2001) } \\
\text { - Líbano/ } \\
\text { Distribuidor que é } \\
\text { também operação } \\
\text { de lojas (2001) }\end{array}$ & $\begin{array}{l}\text { - Portugal/Lojas } \\
\text { multimarcas } \\
\text { - Espanha/Lojas } \\
\text { multimarcas }\end{array}$ & $\begin{array}{c}\text { - Peru/Máster-franquia } \\
\text { (2005) } \\
\text { (2005) } \\
\text { - Itália/Milão/Loja própria } \\
\text { - Colômbia/primeiro lojas } \\
\text { multimarca e segundo lojas } \\
\text { monomarca (2006); } \\
\text { - Guatemala/Máster-franquia } \\
\text { (2006); } \\
\text { - Costa Rica/Máster-franquia } \\
\text { da Guatemala (2006); } \\
\text { - Portugal/Máster-franquia } \\
\text { (2007); } \\
\text { - Espanha/Madri/ Máster- } \\
\text { franquia (2007); } \\
\text { - México/Lojas multimarcas } \\
\text { e loja própria showroom } \\
\text { (2006); } \\
\text { - Chile/Máster-franquia } \\
\text { (2007); } \\
\text { - Bélgica/exportação; } \\
\text { - França/exportação; } \\
\text { - Grécia/exportação }\end{array}$ & $\begin{array}{l}\text { - Panamá; } \\
\text { - Caribe; } \\
\text { - Portugal; } \\
\text { - Peru }\end{array}$ \\
\hline Morana & $\begin{array}{l}\text { - Porto/Loja } \\
\text { própria com } \\
\text { parceiro (2007) }\end{array}$ & $\begin{array}{l}\text { - Nova York/ } \\
\text { Licenciamento } \\
\text { (2007) }\end{array}$ & $\begin{array}{l}\text { - Los Angeles/Loja própria } \\
\text { (2007) }\end{array}$ & $\begin{array}{l}\text { - Los Angeles; } \\
\text { - Portugal; } \\
\text { - Madri }\end{array}$ \\
\hline $\begin{array}{l}\text { Mundo } \\
\text { Verde }\end{array}$ & $\begin{array}{l}\text { - Angola/ Máster- } \\
\text { franquia (2007) }\end{array}$ & Não há & Não há & $\begin{array}{l}\text { - Angola; } \\
\text { - Lisboa; } \\
\text { - Terceiro país }\end{array}$ \\
\hline
\end{tabular}




\begin{tabular}{|c|c|c|c|c|}
\hline Nobel & $\begin{array}{l}\text { - Portugal/ } \\
\text { Exportação } \\
\text { - Angola/ } \\
\text { Exportação }\end{array}$ & $\begin{array}{c}\text { - Portugal/ } \\
\text { Máster-franquia } \\
\text { (2005) }\end{array}$ & $\begin{array}{l}\text { - Espanha/Máster-franquia } \\
\text { (2006) } \\
\text { - Angola/Máster-franquia } \\
\text { (2006) } \\
\text { - México/Máster-franquia } \\
\text { (2006) }\end{array}$ & $\begin{array}{c}\text { - Argentina; } \\
\text { - Colômbia; } \\
\text { - Estados Unidos }\end{array}$ \\
\hline O Boticário & $\begin{array}{c}\text { - Estados Unidos/ } \\
\text { parceira/ abriu e } \\
\text { fechou } \\
\text { - Portugal/ } \\
\text { Franquia (1986) }\end{array}$ & $\begin{array}{l}\text { Operação em 13 } \\
\text { países até 2003: } \\
\text { - Portugal/ } \\
\text { Licenciamento } \\
\text { (1986); } \\
\text { - Japão (1987); } \\
\text { - Bolívia/Peru/ } \\
\text { pequenas } \\
\text { operações } \\
\text { América Latina/ } \\
\text { Licenciamento/ } \\
\text { (entrou e saiu) } \\
\text { - Argentina } \\
\text { (2001) } \\
\text { - México (2001) } \\
\text { - Venezuela/ } \\
\text { Licenciamento }\end{array}$ & $\begin{array}{c}\text { Operação em mais de } 20 \\
\text { países: } \\
\text { - Ásia; } \\
\text { - Angola; } \\
\text { - Austrália; } \\
\text { - África do Sul; } \\
\text { - América Latina }\end{array}$ & Sem previsão \\
\hline Spoleto & $\begin{array}{c}\text { - Registro da } \\
\text { marca no exterior } \\
\text { (1999) }\end{array}$ & $\begin{array}{l}\text { - México/ Cidade } \\
\text { do México/Joint- } \\
\text { venture com } \\
\text { contrato de } \\
\text { máster-franquia } \\
\text { com Grupo Alsea } \\
\text { (2005; sai em } \\
2006)\end{array}$ & $\begin{array}{l}\text { - México/Cidade do México/ } \\
\text { Máster-franquia passa para } \\
\text { Grupo Sernas (2006); } \\
\text { - Portugal/grupo copia } \\
\text { operação (2006); } \\
\text { - Espanha/Máster-franquia } \\
\text { para Península Ibérica (2006) }\end{array}$ & - Estados Unidos \\
\hline $\begin{array}{l}\text { Victor } \\
\text { Hugo }\end{array}$ & $\begin{array}{l}\text { - Nova York/Loja } \\
\text { própria (2005) }\end{array}$ & $\begin{array}{l}\text { - Nova York/ } \\
\text { Distribuição } \\
\text { própria para lojas } \\
\text { multimarcas } \\
\text { (2005) }\end{array}$ & $\begin{array}{l}\text { - Portugal/Máster-franquia } \\
\text { (2007) }\end{array}$ & $\begin{array}{l}\text { - Portugal; } \\
\text { - Espanha; } \\
\text { - França; } \\
\text { - Itália; } \\
\text { - Londres; } \\
\text { - Leste Europeu; } \\
\text { - Miami }\end{array}$ \\
\hline
\end{tabular}

